Prepared in cooperation with the California State Water Resources Control Board A product of the California Groundwater Ambient Monitoring and Assessment (GAMA) Program

\title{
Groundwater-Quality Data in the South Coast Range-Coastal Study Unit, 2008: Results from the California GAMA Program
}

Data Series 504

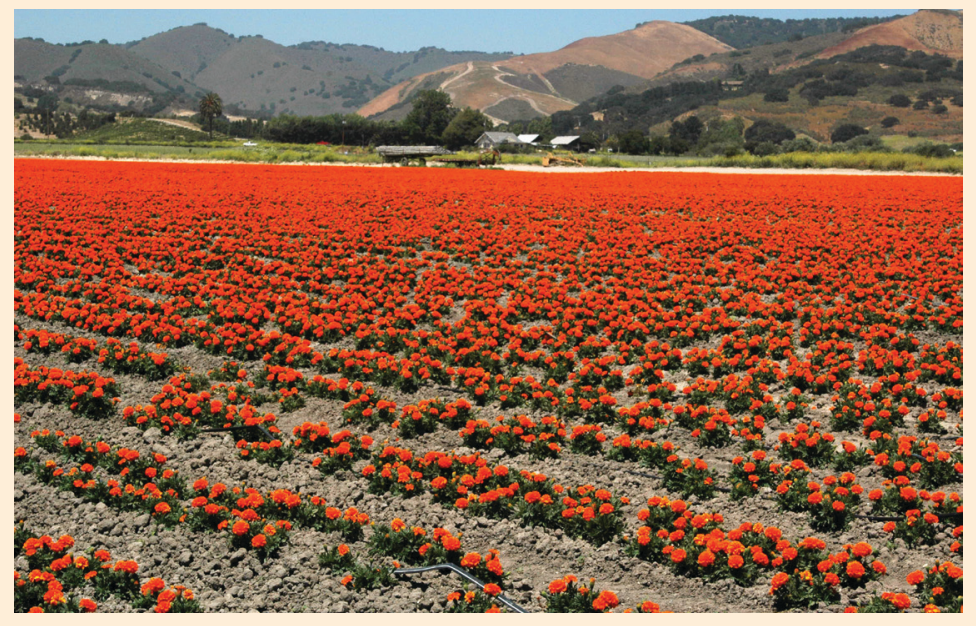




\section{Cover photographs:}

Top right: Irrigation well, Lompoc, California. (Photograph taken by Dara Goldrath, U.S. Geological Survey.)

Bottom center: Marigold farm near Lompoc, California. (Photograph taken by Cathy Munday, U.S. Geological Survey.) 


\section{Groundwater-Quality Data in the South Coast Range-Coastal Study Unit, 2008: Results from the California GAMA Program}

By Timothy M. Mathany, Carmen A. Burton, Michael Land, and Kenneth Belitz

Prepared in cooperation with the California State Water Resources Control Board

Data Series 504 


\title{
U.S. Department of the Interior \\ KEN SALAZAR, Secretary \\ U.S. Geological Survey \\ Marcia K. McNutt, Director
}

\section{U.S. Geological Survey, Reston, Virginia: 2010}

\begin{abstract}
For more information on the USGS — the Federal source for science about the Earth, its natural and living resources, natural hazards, and the environment, visit http://www.usgs.gov or call 1-888-ASK-USGS

For an overview of USGS information products, including maps, imagery, and publications, visit http://www.usgs.gov/pubprod

To order this and other USGS information products, visit http://store.usgs.gov
\end{abstract}

Any use of trade, product, or firm names is for descriptive purposes only and does not imply endorsement by the U.S. Government.

Although this report is in the public domain, permission must be secured from the individual copyright owners to reproduce any copyrighted materials contained within this report.

Suggested citation:

Mathany, T.M., Burton, C.A., Land, Michael, and Belitz, Kenneth, 2010, Groundwater-quality data in the South Coast Range-Coastal study unit, 2008: Results from the California GAMA program: U.S. Geological Survey Data Series 504, $106 \mathrm{p}$. 


\section{Contents}

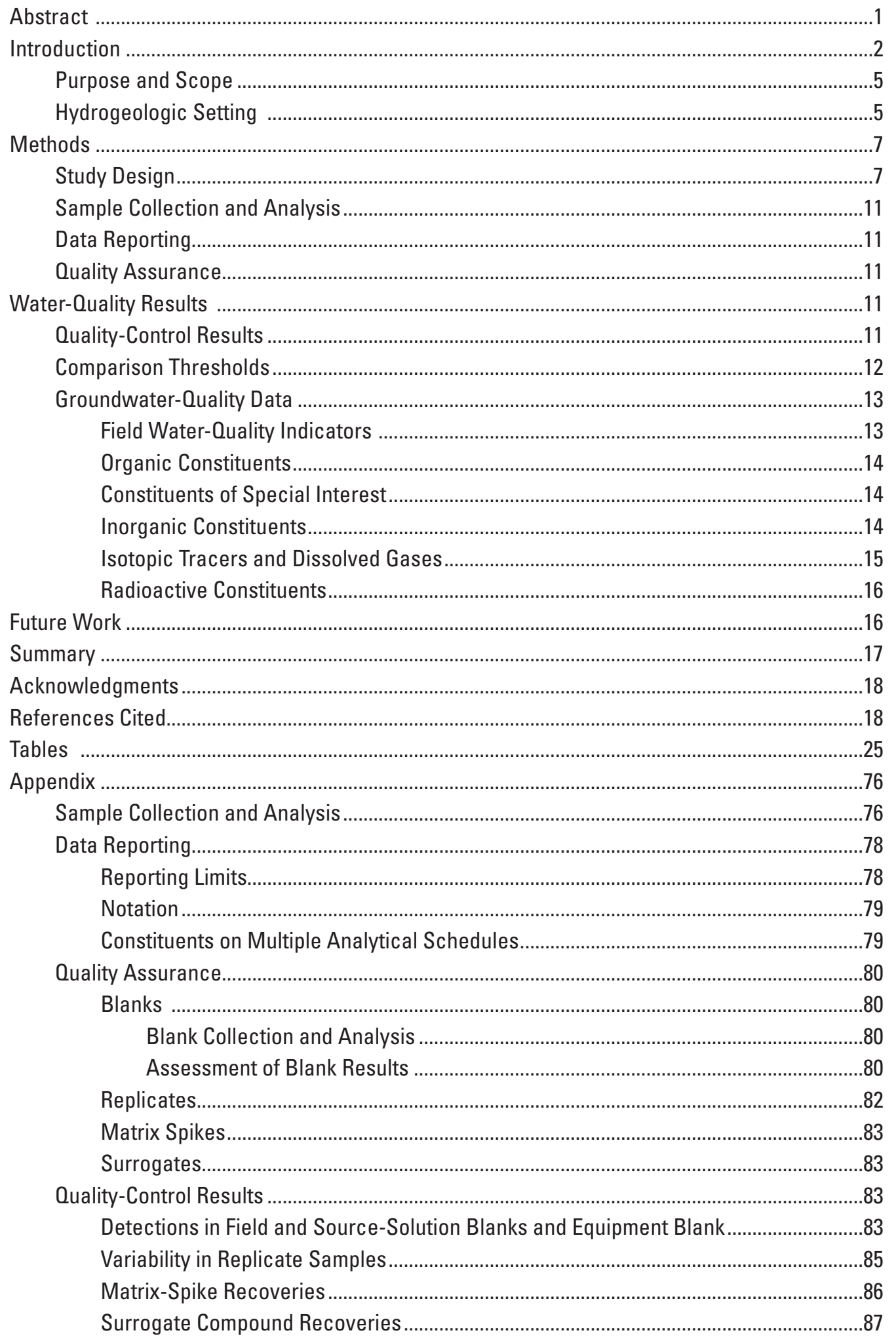




\section{Figures}

Figure 1. Map of the hydrogeologic provinces of California and the location of the South Coast Range-Coastal (SCRC) Groundwater Ambient Monitoring and Assessment (GAMA) study unit

Figure 2. Map of the South Coast Range-Coastal (SCRC) Groundwater Ambient Monitoring and Assessment (GAMA) study unit showing the location and boundaries of the California Department of Water Resources (CDWR) defined groundwater basins, the locations of areas outside of the CDWR-defined groundwater basins that are included in the study unit, the location of major cities, topographic features, and hydrologic features

Figure 3. Map of the South Coast Range-Coastal (SCRC) Groundwater Ambient Monitoring and Assessment (GAMA) study unit showing the boundaries of the Basins and Uplands study areas, the location of public-supply wells with a record in the California Department of Public Health (CDPH) Database, major cities, major roads, topographic features, and hydrologic features

Figure 4. Map of the South Coast Range-Coastal (SCRC) Groundwater Ambient Monitoring and Assessment (GAMA) study unit showing the distribution of the Basins and Uplands study area-grid cells, the location of sampled grid and understanding wells and surface-water sites, major cities, major roads, topographic features, and hydrologic features

\section{Tables}

Table 1. Identification, sampling, and construction information for wells and identification and sampling information for surface-water sites sampled for the South Coast Range-Coastal (SCRC) Groundwater Ambient Monitoring and Assessment (GAMA) study, California, May to December 2008

Table 2. Classes of chemical constituents and field water-quality indicators collected for the slow, fast, and special study well sampling schedules and the surface-water schedule in the South Coast Range-Coastal (SCRC) Groundwater Ambient Monitoring and Assessment (GAMA) study, California, May to December 2008

Table 3A. Volatile organic compounds (VOC), primary uses or sources, comparative thresholds, and reporting information for the U.S. Geological Survey (USGS) National Water Quality Laboratory Schedule 2020

Table 3B. Pesticides and pesticide degradates, primary uses or sources, comparative thresholds, and reporting information for the U.S. Geological Survey (USGS) National Water Quality Laboratory Schedule 2003

Table 3C. Polar pesticides and metabolites, primary uses or sources, comparative thresholds, and reporting information for the U.S. Geological Survey (USGS) National Water Quality Laboratory Schedule 2060

Table 3D. Pharmaceutical compounds, primary uses or sources, comparative thresholds, and reporting information for the U.S. Geological Survey (USGS) National Water Quality Laboratory Schedule 2080

Table 3E. Constituents of special interest (perchlorate, N-nitrosodimethylamine [NDMA], and 1,2,3-TCP), primary uses or sources, comparative thresholds, and reporting information for Weck Laboratories, Inc. analyses

Table 3F. Trace elements, comparative thresholds, and reporting information for the U.S. Geological Survey (USGS) National Water Quality Laboratory Schedule 1948 
Table 3G. Nutrients and dissolved organic carbon (DOC), comparative thresholds, and reporting information for the U.S. Geological Survey (USGS) National Water Quality Laboratory Schedules 2755 and 2702 and Laboratory Code 2612

Table 3H. Major and minor ions, silica, total dissolved solids (TDS), and alkalinity, comparative thresholds, and reporting information for the U.S. Geological Survey (USGS) National Water Quality Laboratory Schedule 1948

Table 3I. Arsenic and iron species, comparative thresholds, and reporting information for the U.S. Geological Survey (USGS) Trace Metal Laboratory, Boulder, Colorado analyses

Table 3J. Isotopic and radioactive constituents, comparative thresholds, and reporting information for laboratory analyses

Table 3K. Dissolved gases and tritium, comparison thresholds and reporting information for the U.S. Geological Survey (USGS) Chlorofluorocarbon Laboratory and Lawrence Livermore National Laboratory analyses

Table 4. Field water-quality indicators in samples collected for the South Coast Range-Coastal (SCRC) Groundwater Ambient Monitoring and Assessment (GAMA) study, California, May to December 2008

Table 5. Volatile organic compounds (VOC) detected in samples collected for the South Coast Range-Coastal (SCRC) Groundwater Ambient Monitoring and Assessment (GAMA) study, California, May to December 2008

Table 6A. Pesticides and pesticide degradates detected in samples collected for the South Coast Range-Coastal (SCRC) Groundwater Ambient Monitoring and Assessment (GAMA) study, California, May to December 2008

Table 6B. Polar pesticides and metabolites detected in samples collected for the South Coast Range-Coastal (SCRC) Groundwater Ambient Monitoring and Assessment (GAMA) study, California, May to December 2008

Table 7. Perchlorate detected in the samples collected for the South Coast Range-Coastal (SCRC) Groundwater Ambient Monitoring and Assessment (GAMA) study, California, May to December 2008

Table 8. Trace elements detected in the samples collected for the South Coast Range-Coastal (SCRC) Groundwater Ambient Monitoring and Assessment (GAMA) study, California, May to December 2008

Table 9. Nutrients and dissolved organic carbon (DOC) detected in samples collected for the South Coast Range-Coastal (SCRC) Groundwater Ambient Monitoring and Assessment (GAMA) study, California, May to December 2008

Table 10. Major and minor ions, silica, and total dissolved solids (TDS) detected in samples collected for the South Coast Range-Coastal (SCRC) Groundwater Ambient Monitoring and Assessment (GAMA) study, California, May to December 2008

Table 11. Species of inorganic arsenic and iron detected in samples collected for the South Coast Range-Coastal (SCRC) Groundwater Ambient Monitoring and Assessment (GAMA) study, California, May to December 2008

Table 12. Results for analyses of stable isotope ratios, tritium activity, and carbon-14 abundance detected in samples collected for the Southern Coast Range-Coastal (SCRC) Groundwater Ambient Monitoring and Assessment (GAMA) study, California, May to December 2008.

Table 13. Results for analyses of dissolved gases detected in samples collected for the Southern Coast Range-Coastal (SCRC) Groundwater Ambient Monitoring and Assessment (GAMA) study, California, May to December 2008 
Table 14. Gross alpha and gross beta radioactivity detected in samples collected for the South Coast Range-Coastal (SCRC) Groundwater Ambient Monitoring and Assessment (GAMA) study, California, May to December 2008

Table A1. Analytical methods used for the determination of organic and inorganic constituents by the U.S. Geological Survey (USGS) National Water Quality Laboratory (NWOL) and contract laboratories 88

Table A2. Preferred analytical schedules for constituents appearing on multiple schedules for samples collected for the South Coast Range-Coastal (SCRC) Groundwater Ambient Monitoring and Assessment (GAMA) study, California, May to December 2008

Table A3. Constituents detected in blanks collected for the South Coast Range-Coastal (SCRC) Groundwater Ambient Monitoring and Assessment (GAMA) study, California, May to December 2008

Table A4A. Quality-control summary for replicate analyses of organic constituents detected in samples collected for the South Coast Range-Coastal (SCRC) Groundwater Ambient Monitoring and Assessment (GAMA) study, California, May to December 2008

Table A4B. Quality-control summary for replicate analyses of inorganic constituents, isotope tracers, and radioactivity detected in samples collected for the South Coast Range-Coastal (SCRC) Groundwater Ambient Monitoring and Assessment (GAMA) study, California, May to December 2008

Table A4C. Quality-control summary for replicate analyses of gross alpha and gross beta radioactivity detected in samples collected for the South Coast Range-Coastal (SCRC) Groundwater Ambient Monitoring and Assessment (GAMA) study, California, May to December 2008.

Table A5A. Quality-control summary for matrix-spike recoveries of volatile organic compounds (VOC) in samples collected for the South Coast Range-Coastal (SCRC) Groundwater Ambient Monitoring and Assessment (GAMA) study, California, May to December 2008.

Table A5B. Quality-control summary for matrix-spike recoveries of pesticides and pesticide degradates in samples collected for the South Coast Range-Coastal (SCRC) Groundwater Ambient Monitoring and Assessment (GAMA) study, California, May to December 2008

Table A5C. Quality-control summary for matrix-spike recoveries of polar pesticides and metabolites in samples collected for the South Coast Range-Coastal (SCRC) Groundwater Ambient Monitoring and Assessment (GAMA) study, California, May to December 2008

Table A5D. Quality-control summary for matrix-spike recoveries of constituents of special interest in samples collected for the South Coast Range-Coastal (SCRC) Groundwater Ambient Monitoring and Assessment (GAMA) study, California, May to December 2008 104

Table A5E. Quality-control summary for matrix-spike recoveries of gross alpha and gross beta radioactivity in samples collected for the South Coast Range-Coastal (SCRC) Groundwater Ambient Monitoring and Assessment (GAMA) study, California, May to December 2008.

Table A6. Quality-control summary for surrogate recoveries of volatile organic compounds (VOC), pesticides and pesticide degradates, and polar pesticides and metabolites in samples collected for the South Coast Range-Coastal (SCRC) Groundwater Ambient Monitoring and Assessment (GAMA) study, California, May to December 2008 


\section{Abbreviations and Acronyms}

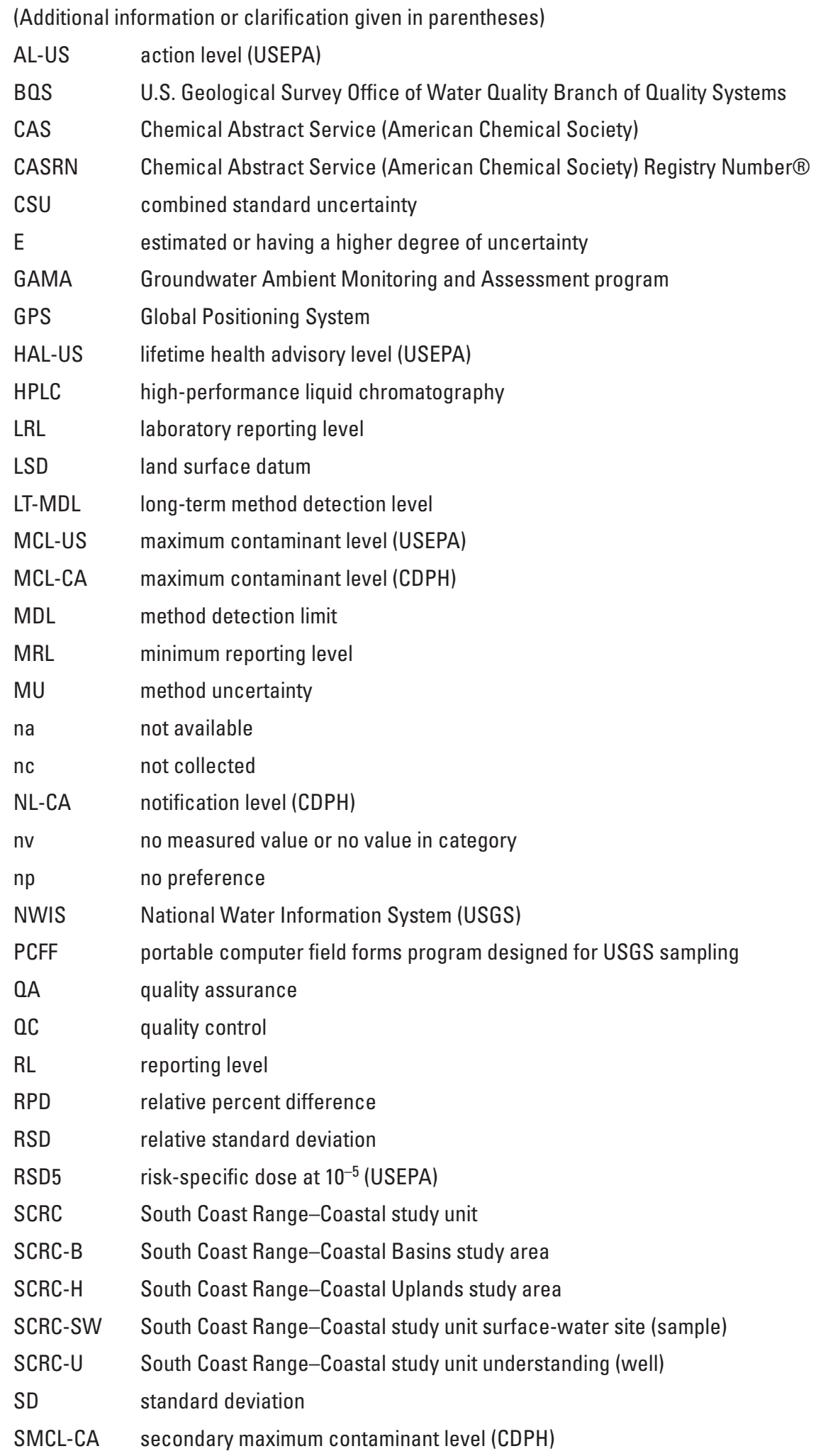


SRL study reporting limit (concentration cutoff for applying the $\leq$ symbol)

$\mathrm{ssL}_{\mathrm{C}} \quad$ sample-specific critical level

US United States

UV ultraviolet

V analyte detected in sample and associated blank; thus, data are not included in groundwater quality assessment

VCDT Vienna Canon Diablo Troilite (the international reference standard for sulfur isotopes)

VPDB Vienna Pee Dee Belemnite (the international reference standard for carbon isotopes)

VSMOW Vienna Standard Mean Ocean Water (an isotopic water standard defined in 1968 by the International Atomic Energy Agency)

\section{Organizations}

CDPH California Department of Public Health

CDPR California Department of Pesticide Regulation

CDWR California Department of Water Resources

LLNL Lawrence Livermore National Laboratory

NAWQA National Water Quality Assessment (USGS)

NELAP National Environmental Laboratory Accreditation Program

NWQL National Water Quality Laboratory (USGS)

NRP National Research Program (USGS)

SWRCB State Water Resources Control Board

TML Trace Metal Laboratory (USGS)

USEPA U.S. Environmental Protection Agency

USGS U.S. Geological Survey

\section{Selected Chemical Names}

$\begin{array}{ll}\text { 1,2,3-TCP } & \text { 1,2,3-Trichloropropane } \\ \mathrm{CaCO}_{3} & \text { calcium carbonate } \\ \mathrm{CO}_{3}{ }^{-2} & \text { carbonate } \\ \mathrm{CFC} & \text { chlorofluorocarbon } \\ \mathrm{H}_{2} \mathrm{O} & \text { water } \\ \mathrm{HCl} & \text { hydrochloric acid } \\ \mathrm{HCO}_{3}^{-} & \text {bicarbonate } \\ \mathrm{MTBE}^{-} & \text {methyl tert-butyl ether } \\ \mathrm{Na}_{2} \mathrm{~S}_{2} \mathrm{O}_{3} & \text { sodium thiosulfate } \\ \mathrm{NDMA}^{-} & \text {N-nitrosodimethylamine } \\ \mathrm{NO}_{2}^{-}+\mathrm{NO}_{3}^{-} & \text {nitrite plus nitrate, as nitrogen } \\ \mathrm{PCE} & \text { perchloroethene (tetrachloroethene) } \\ \mathrm{SiO}_{2} & \text { silicon dioxide }\end{array}$




$\begin{array}{ll}\text { TCE } & \text { trichloroethene } \\ \text { TDS } & \text { total dissolved solids } \\ \text { THM } & \text { trihalomethane } \\ \text { VOC } & \text { volatile organic compound }\end{array}$

\section{Selected Terms and Symbols}

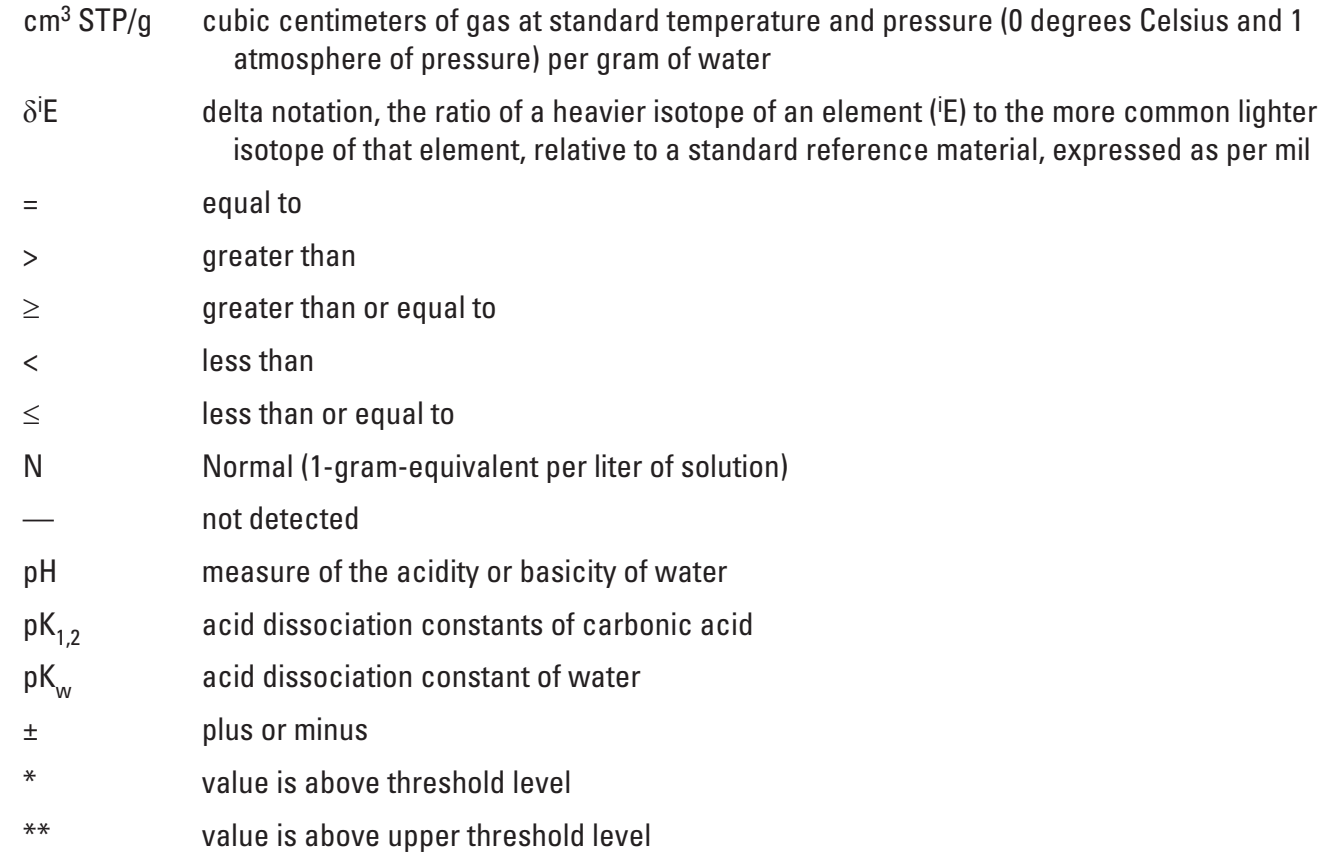

\section{Notes}

Temperature in degrees Celsius $\left({ }^{\circ} \mathrm{C}\right)$ may be converted to degrees Fahrenheit $\left({ }^{\circ} \mathrm{F}\right)$ as follows:

$$
{ }^{\circ} \mathrm{F}=\left(1.8 \times{ }^{\circ} \mathrm{C}\right)+32 \text {. }
$$

Vertical coordinate information is referenced to the North American Vertical Datum of 1988 (NAVD 88).

Horizontal coordinate information is referenced to the North American Datum of 1983 (NAD 83). Altitude, as used in this report, refers to distance above the vertical datum.

Specific conductance is given in microsiemens per centimeter at 25 degrees Celsius $(\mu \mathrm{S} / \mathrm{cm}$ at $\left.25^{\circ} \mathrm{C}\right)$.

Turbidity is given in nephelometric turbidity units (NTRU).

Concentrations of chemical constituents in water are given either in milligrams per liter (mg/L) or micrograms per liter ( $\mu \mathrm{g} / \mathrm{L})$.

Milligrams per liter is equivalent to parts per million (ppm) and micrograms per liter is equivalent to parts per billion (ppb).

Concentrations of radioactive constituents in water are given in picocuries per liter (pCi/L). 
This page intentionally left blank. 


\title{
Groundwater-Quality Data in the South Coast Range-Coastal Study Unit, 2008: Results from the California GAMA Program
}

\author{
By Timothy M. Mathany, Carmen A. Burton, Michael Land, and Kenneth Belitz
}

\section{Abstract}

Groundwater quality in the approximately 766-squaremile South Coast Range-Coastal (SCRC) study unit was investigated from May to December 2008, as part of the Priority Basins Project of the Groundwater Ambient Monitoring and Assessment (GAMA) Program. The GAMA Priority Basins Project was developed in response to legislative mandates (Supplemental Report of the 1999 Budget Act 1999-00 Fiscal Year; and, the Groundwater Quality Monitoring Act of 2001 [Sections 10780-10782.3 of the California Water Code, Assembly Bill 599]) to assess and monitor the quality of groundwater in California, and is being conducted by the U.S. Geological Survey (USGS) in cooperation with the California State Water Resources Control Board (SWRCB). The SCRC study unit was the 25th study unit to be sampled as part of the GAMA Priority Basins Project.

The SCRC study unit was designed to provide a spatially unbiased assessment of untreated groundwater quality in the primary aquifer systems and to facilitate statistically consistent comparisons of untreated groundwater quality throughout California. The primary aquifer systems (hereinafter referred to as primary aquifers) were defined as that part of the aquifer corresponding to the perforation interval of wells listed in the California Department of Public Health (CDPH) database for the SCRC study unit. The quality of groundwater in shallow or deep water-bearing zones may differ from the quality of groundwater in the primary aquifers; shallow groundwater may be more vulnerable to surficial contamination.

In the SCRC study unit, groundwater samples were collected from 70 wells in two study areas (Basins and Uplands) in Santa Barbara and San Luis Obispo Counties. Fifty-five of the wells were selected using a spatially distributed, randomized grid-based method to provide statistical representation of the study unit (grid wells), and 15 wells were selected to aid in evaluation of specific water-quality issues (understanding wells). In addition to the 70 wells sampled, 3 surface-water samples were collected in streams near 2 of the sampled wells in order to better comprehend the interaction between groundwater and surface water in the area.

The groundwater samples were analyzed for organic constituents (volatile organic compounds [VOC], pesticides and pesticide degradates, polar pesticides and metabolites, and pharmaceutical compounds), constituents of special interest (perchlorate, $N$-nitrosodimethylamine [NDMA], and 1,2,3-TCP), naturally occurring inorganic constituents (trace elements, nutrients, dissolved organic carbon [DOC], major and minor ions, silica, total dissolved solids [TDS], and alkalinity), and radioactive constituents (gross alpha and gross beta radioactivity). Naturally occurring isotopes (stable isotopes of hydrogen and oxygen in water, stable isotopes of nitrogen and oxygen in dissolved nitrate, stable isotopes of sulfur in dissolved sulfate, stable isotopes of carbon in dissolved inorganic carbon, activities of tritium, and carbon-14 abundance), and dissolved gases (including noble gases) also were measured to help identify the sources and ages of the sampled groundwater. In total, 298 constituents and field water-quality indicators were investigated.

Three types of quality-control samples (blanks, replicates, and matrix-spikes) were collected at approximately 3 to 12 percent of the wells in the SCRC study unit, and the results for these samples were used to evaluate the quality of the data for the groundwater samples. Field blanks rarely contained detectable concentrations of any constituent, suggesting that contamination from sample collection procedures was not a significant source of bias in the data for the groundwater samples. Differences between replicate samples generally were less than 10 percent relative and/or standard deviation, indicating acceptable analytical reproducibility. Matrixspike recoveries were within the acceptable range (70 to 130 percent) for approximately 84 percent of the compounds. 
This study did not attempt to evaluate the quality of drinking water delivered to consumers; after withdrawal from the ground, untreated groundwater typically is treated, disinfected, and/or blended with other waters to maintain water quality. Regulatory thresholds apply to water that is served to the consumer, not to untreated groundwater. However, to provide some context for the results, concentrations of constituents measured in the untreated groundwater were compared with regulatory and nonregulatory health-based thresholds established by the U.S. Environmental Protection Agency (USEPA) and CDPH, and to non-regulatory thresholds established for aesthetic concerns by CDPH. Comparisons between data collected for this study and thresholds for drinking water are for illustrative purposes only and are not indicative of compliance or noncompliance with those thresholds.

Most organic and inorganic constituents that were detected in groundwater samples from the 55 grid wells in the SCRC study unit were detected at concentrations less than drinking-water thresholds. In addition, all detections of organic constituents in SCRC grid well samples were less than health-based thresholds.

In total, VOCs were detected in 33 percent of the 55 grid wells sampled and pesticides and pesticide degradates were detected in 27 percent of grid wells sampled in the SCRC study unit. In the Basins study area, VOCs and pesticides and pesticide degradates were detected in approximately 33 percent of the 39 grid wells. In the Uplands study area, VOCs were detected in approximately 31 percent and pesticides and pesticide degradates were detected in approximately 13 percent of the 16 grid wells.

Trace elements and minor ions were sampled for at 32 grid wells and nutrients at 33 grid wells in the SCRC study unit, and most detections were less than health-based thresholds. Exceptions in the Basins study area include one detection of arsenic greater than the USEPA maximum contaminant level (MCL-US) of $10 \mu \mathrm{g} / \mathrm{L}$ and three detections of nitrite plus nitrate, as nitrogen $\left(\mathrm{NO}_{2}^{-}+\mathrm{NO}_{3}^{-}\right)$greater than the MCL-US of $10 \mathrm{mg} / \mathrm{L}$. Exceptions in the Uplands study area include two detections of arsenic greater than the MCL-US and eight detections of molybdenum greater than the USEPA lifetime health advisory level (HAL-US) of $40 \mu \mathrm{g} / \mathrm{L}$. All detections of major and minor ions and gross alpha and gross beta radioactivity from the SCRC grid wells were less than health-based thresholds.

Results for trace elements, major ions, and TDS with non-enforceable thresholds set for aesthetic concerns from 16 Basins study area grid wells showed that iron concentrations greater than the $\mathrm{CDPH}$ secondary maximum contaminant level (SMCL-CA) of $300 \mu \mathrm{g} / \mathrm{L}$ were detected in grid wells. Manganese concentrations greater than the SMCL-CA of $50 \mu \mathrm{g} / \mathrm{L}$ were detected in six grid wells.
Chloride concentrations greater than the recommended SMCL-CA threshold of $250 \mathrm{mg} / \mathrm{L}$ were detected in one grid well. Sulfate concentrations greater than the recommended SMCL-CA threshold of $250 \mathrm{mg} / \mathrm{L}$ were measured in 12 grid wells and 3 of these wells also were greater than the upper SMCL-CA threshold of $500 \mathrm{mg} / \mathrm{L}$. TDS concentrations greater than the SMCL-CA recommended threshold of $500 \mathrm{mg} / \mathrm{L}$ were measured in 14 of the 16 Basins study area grid wells and concentrations in 5 of these wells also were greater than the SMCL-CA upper threshold of $1,000 \mathrm{mg} / \mathrm{L}$.

In the Uplands study area, iron concentrations greater than the SMCL-CA were detected in 2 of 16 grid wells and manganese concentrations greater than the SMCL-CA were detected in 3 grid wells. TDS and sulfate concentrations greater than the recommended SMCL-CA thresholds were detected in 11 and 2 grid wells, respectively, but none of these concentrations were greater than the SMCL-CA upper thresholds.

\section{Introduction}

Groundwater comprises about one-half of the water used for public and domestic drinking-water supply in California (Hutson and others, 2004). To assess the quality of ambient groundwater in aquifers used for public drinking-water supply and to establish a baseline groundwater-quality monitoring program, the State Water Resources Control Board (SWRCB) in cooperation with the U.S. Geological Survey (USGS) and Lawrence Livermore National Laboratory (LLNL) implemented the Groundwater Ambient Monitoring and Assessment (GAMA) Program (http://www.waterboards. ca.gov/gama). The statewide GAMA program currently consists of three Projects: GAMA Priority Basins Project conducted by the USGS (http://ca.water.usgs.gov/gama/), GAMA Domestic Well Project conducted by the SWRCB, and GAMA Special Studies conducted by LLNL. Statewide, the GAMA Priority Basins Project primarily focused on the deep part of the groundwater resource and the GAMA Domestic Well Project generally focused on the shallow aquifer systems.

All published and quality-assurance/quality-control (QA/QC) approved analytical data collected for the GAMA program are stored in the web-based Geotracker Database (https://geotracker.waterboards.ca.gov/gama/). The Geotracker Database also stores groundwater-quality data and related reports collected by other State agencies, such as the California Department of Public Health (CDPH), California Department of Water Resources (CDWR), California Department of Pesticide Regulation (CDPR), and data collected by the SWRCB and other Regional Boards from environmental monitoring wells at contaminated and/or remediated sites. 
The SWRCB initiated the GAMA Program in 2000 in response to a legislative mandate (Supplemental Report of the 1999 Budget Act 1999-00 Fiscal Year). The GAMA Priority Basins Project was initiated in response to the Groundwater Quality Monitoring Act of 2001 (Sections 10780-10782.3 of the California Water Code, Assembly Bill 599) to assess and monitor the quality of groundwater in California. The GAMA Priority Basins Project is a comprehensive assessment of statewide groundwater quality designed to help better understand and identify risks to groundwater resources and to increase the availability of information about groundwater quality to the public. For the GAMA Priority Basins Project, the USGS, in collaboration with the SWRCB, developed the monitoring plan to assess groundwater basins through direct and other statistically reliable sample approaches (Belitz and others, 2003; State Water Resources Control Board, 2003). Additional partners in the GAMA Priority Basins Project include LLNL, CDPH, CDWR, CDPR, and local water agencies and well owners (Kulongoski and Belitz, 2004). Local participation in the project is entirely voluntary.

The GAMA Priority Basins Project is unique in California because it includes many chemical analyses that are not otherwise available in statewide water-quality monitoring datasets. Groundwater samples collected for the project are analyzed for approximately 300 chemical constituents using analytical methods with lower detection limits than required by the CDPH for regulatory monitoring of drinking-water wells. These analyses will be especially useful for providing an early indication of changes in groundwater quality. In addition, the GAMA Priority Basins Project analyzes samples for a suite of constituents more extensive than that required by CDPH and for a suite of chemical and isotopic tracers for exploring hydrologic and geochemical processes. A broader understanding of groundwater composition is useful for identifying the natural and human factors affecting water quality. Understanding the occurrence and distribution of chemical constituents of significance to water quality is important for the long-term management and protection of groundwater resources.

The range of hydrologic, geologic, and climatic conditions that exist in California must be considered in an assessment of groundwater quality. Belitz and others (2003) partitioned the State into 10 hydrogeologic provinces, each with distinctive hydrologic, geologic, and climatic characteristics (fig. 1). All these hydrogeologic provinces include groundwater basins and subbasins designated by the CDWR (California Department of Water Resources, 2003).
Groundwater basins and subbasins generally consist of relatively permeable, unconsolidated deposits of alluvial or volcanic origin. Eighty percent of California's approximately 16,000 active and standby drinking-water wells listed in the statewide database maintained by the CDPH (hereinafter referred to as CDPH wells) are located in groundwater basins and subbasins within the 10 hydrologic provinces. Groundwater basins and subbasins were prioritized for sampling on the basis of the number of CDPH wells in the basin, with secondary consideration given to municipal groundwater use, agricultural pumping, the number of formerly leaking underground fuel tanks, and registered pesticide applications (Belitz and others, 2003). Of the 472 basins and subbasins designated by the CDWR, 116 priority basins were selected and grouped into 36 study units, representing approximately 95 percent of the $\mathrm{CDPH}$ wells in California. In addition, some areas outside of the defined groundwater basins were included in the nearest respective study unit to achieve representation of the 20 percent of the $\mathrm{CDPH}$ wells not located in the groundwater basins.

Three types of water-quality assessments are being conducted with the data collected in each study unit: (1) Status: assessment of the current quality of the groundwater resource; (2) Trends: detection of changes in groundwater quality; and (3) Understanding: identification of the natural and human factors affecting groundwater quality (Kulongoski and Belitz, 2004). The assessments are intended to characterize the quality of groundwater in the primary aquifer systems of the study units, not the treated drinking water delivered to consumers by water purveyors. The primary aquifer systems (hereinafter referred to as primary aquifers) are defined as that part of the aquifer corresponding to the perforation interval of wells listed in the CDPH database for the study units. The CDPH Database lists wells used for municipal and community drinking-water supplies, and includes wells from systems classified as non-transient (such as cities, towns, and mobile-home parks) and transient (such as schools, campgrounds, and restaurants). The CDPH refers to these wells as "public-supply" wells. Groundwater quality in shallow or deep parts of the aquifer systems may differ from that in the primary aquifers. In particular, shallow groundwater may be more vulnerable to surface contamination. As a result, samples from shallow wells (such as many private domestic wells and environmental monitoring wells) can have higher concentrations of constituents from anthropogenic sources (such as VOCs and nitrate) than samples from wells screened in the deep primary aquifer (Landon and others, 2010). 


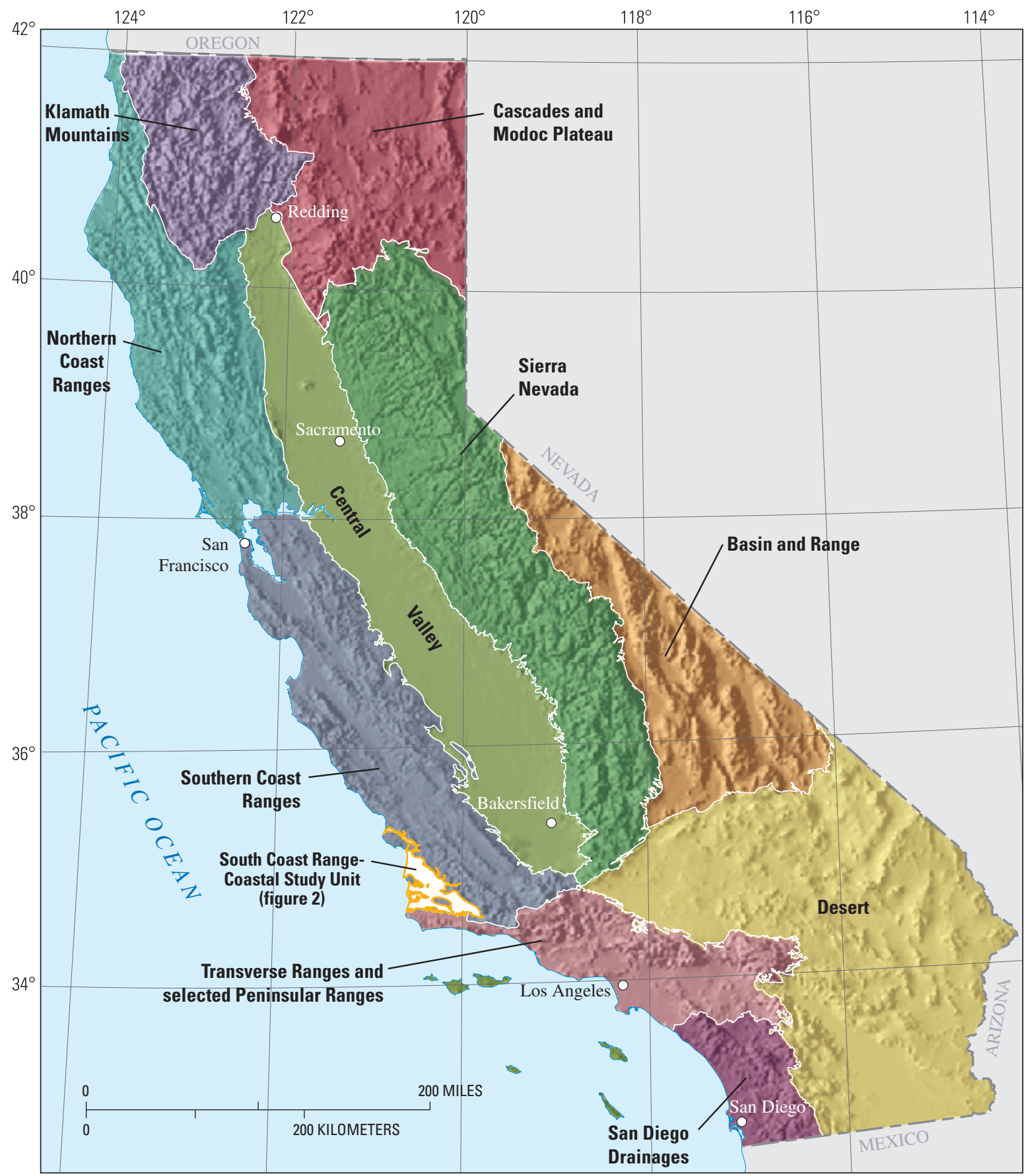

Shaded relief derived from U.S. Geological Survey

Provinces from Belitz and others, 2003. National Elevation Dataset, 2006.

Albers Equal Area Conic Projection

Figure 1. The hydrogeologic provinces of California and the location of the South Coast Range-Coastal (SCRC) Groundwater Ambient Monitoring and Assessment (GAMA) study unit. 
This data series report is the first in a series of reports presenting the water-quality data collected in the Southern Coast Range-Coastal study unit and is similar to Data Series Reports written for the GAMA study units sampled to date (San Diego Drainages Hydrogeologic Province: Wright and others, 2005; Northern San Joaquin Basin: Bennett and others, 2006; North San Francisco Bay: Kulongoski and others, 2006; Southern Sierra: Fram and Belitz, 2007; Monterey Bay and Salinas Valley Basins: Kulongoski and Belitz, 2007; Southeast San Joaquin Valley: Burton and Belitz, 2008; Southern Sacramento Valley: Dawson and others, 2008; Central Sierra: Ferrari and others, 2008; San Fernando-San Gabriel: Land and Belitz, 2008; Central Eastside San Joaquin: Landon and Belitz, 2008; Coastal Los Angeles Basin: Mathany and others, 2008; Middle Sacramento Valley: Schmitt and others, 2008; Kern County Subbasin: Shelton and others, 2008; Northern Sacramento Valley: Bennett and others, 2009; Owens and Indian Wells Valleys: Densmore and others, 2009; Tahoe-Martis: Fram and others, 2009; Coachella Valley: Goldrath and others, 2009; Upper Santa Ana Watershed: Kent and Belitz, 2009; Mojave: Mathany and Belitz, 2009; South Coast Interior Basins: Mathany and others, 2009; Santa Clara River Valley: Montrella and Belitz, 2009; San Francisco Bay: Ray and others, 2009; Madera-Chowchilla: Shelton and others, 2009; Colorado River: Goldrath and others, 2010). Subsequent reports will address the status, trends, and understanding aspects of the water-quality assessments of each study unit.

The GAMA Southern Coast Range-Coastal (SCRC) study unit (hereinafter referred to as SCRC), contains five groundwater basins delineated by CDWR and is located along the California coast in the Southern Coast Ranges hydrogeologic province. Groundwater is a major source of public drinking-water supply for many of the cities located in the SCRC (Water Education Foundation, 2006, http://www. water-ed.org/watersources/default.asp). Therefore, SCRC was considered high priority for sampling to provide adequate representation of the Southern Coast Ranges hydrogeologic province (Belitz and others, 2003).

\section{Purpose and Scope}

The purposes of this report are to describe (1) the study design, including the hydrogeologic setting of SCRC and the study methods, (2) the results of quality-control tests, and (3) the analytical results for groundwater samples collected in SCRC. Groundwater samples were analyzed for field water-quality indicators, organic and inorganic constituents, radioactive constituents, naturally occurring isotopes, and dissolved gases. The chemical data presented in this report were evaluated by comparison to State and Federal drinking-water regulatory and other non-regulatory standards that are applied to treated drinking water. Regulatory and non-regulatory thresholds considered for this report are those established by the U. S. Environmental Protection Agency (USEPA) and/or the CDPH. The data presented in this report are intended to characterize the quality of untreated groundwater in the primary aquifers of the SCRC, not the treated drinking water delivered to consumers by water purveyors. Discussion of the factors that influence the distribution and occurrence of the constituents detected in groundwater samples will be the subject of subsequent publications.

\section{Hydrogeologic Setting}

The SCRC lies in the southwestern part of the Southern Coast Ranges hydrogeologic province as described by Belitz and others (2003), and includes five CDWR-defined groundwater basins: Los Osos Valley, San Luis Obispo, Santa Maria River Valley, San Antonio Creek Valley, and Santa Ynez River Valley (California Department of Water Resources, 2004a,b,c,d,e). The SCRC covers an area of approximately 766-square-mile ( $\left.\mathrm{mi}^{2}\right)$, in Santa Barbara and San Luis Obispo Counties, California. The SCRC is bordered on the north by the Santa Lucia and San Luis Ranges, on the east by the San Rafael Mountains, on the south by the Santa Ynez Mountains, and on the west by the Pacific Ocean (fig. 2).

Altitudes in the SCRC range from sea level, where the study unit boundary touches the Pacific Ocean, to about 6,500 feet above sea level, in the San Rafael Mountains. The major surface drainage features of the SCRC are the Santa Maria and Santa Ynez Rivers and San Antonio Creek and their tributaries; all of which terminate in the Pacific Ocean (figs $2,3,4$ ).

The climate in the SCRC is influenced in large part by the Pacific Ocean and also by the topography of the surrounding areas. Areas located along the coastal lowlands and/or valleys near the Pacific Ocean have a coastal climate. It is characterized by warm dry summers and cool wet winters. Coastal fog is common throughout the year (Bright and others, 1992). Areas in the SCRC located farther from the Pacific Ocean, on the slopes of the coastal valleys and/or within the upland areas have a Mediterranean climate, with hot dry summers and cool wet winters (Hamlin, 1985). Practically all precipitation in the SCRC occurs from October through April, with average annual precipitation ranging from a low of around 13 inches (in.) along the coastal lowlands in the Santa Maria River Valley groundwater basin, to more than $20 \mathrm{in}$. in the uplands of the San Luis Obispo groundwater basin (California Department of Water Resources, 2004b,c). 


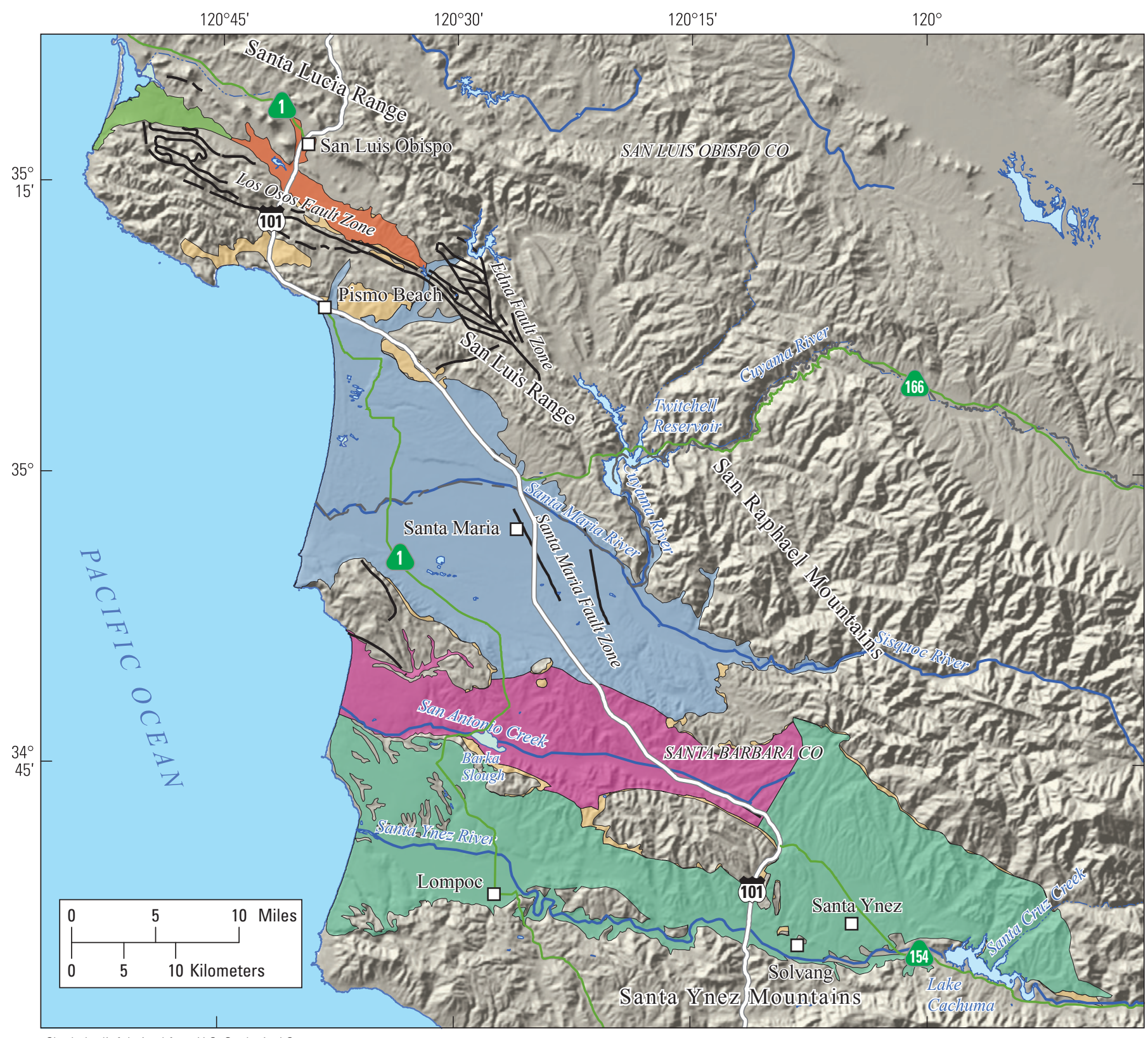

Shaded relief derived from U.S. Geological Survey

National Elevation Dataset, 2006.

Albers Equal Area Conic Projection

\section{EXPLANATION}

Groundwater basins (from California Department of Water Resources, CDWR)

\begin{tabular}{|c|}
\hline Los Osos Valley \\
\hline San Luis Obispo \\
\hline Santa Maria River Valley \\
\hline
\end{tabular}

San Antonio Creek Valley

Santa Ynez River Valley

Areas outside of the groundwater basins that are included in the study unit

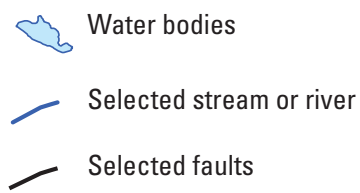

Selected faults

Figure 2. The South Coast Range-Coastal (SCRC) Groundwater Ambient Monitoring and Assessment (GAMA) study unit showing the location and boundaries of the California Department of Water Resources (CDWR) defined groundwater basins, the locations of areas outside of the CDWR-defined groundwater basins that are included in the study unit, the location of major cities, topographic features, and hydrologic features. 
Two primary water-bearing formations serve as the primary aquifers for all five groundwater basins of the SCRC: the Paso Robles Formation and Holocene age alluvial deposits of non-marine and fluvial origin. The Pleistocene age Paso Robles Formation consists of unconsolidated to poorly consolidated coarse sand and gravel, as well as finer sand, silt, and clay and some limestone that formed from deposition in floodplains and small lakes. The water-bearing units are underlain by non-water-bearing Tertiary and Cretaceous bedrock and granite (Valentine and others, 2001). The Holocene age alluvium consists of unconsolidated gravel, clay, silt, and sand of fluvial origin (California Department of Water Resources, 2004a,b,c,d,e).

The SCRC was separated into the two study areas (Basins and Uplands) by the marine and terrestrial geologic formations not common to the five groundwater basins. The Basins study area boundaries were defined by the locality of the marine sand formations in the Los Osos Valley, Santa Maria River Valley, San Antonio Creek Valley, and Santa Ynez River Valley groundwater basins (California Department of Water Resources, 2004a,c,d,e) (fig. 3). The Uplands study area borders were delineated largely by the location of the terrace formations in the San Luis Obispo, Santa Maria River Valley, San Antonio Creek Valley, and Santa Ynez River Valley groundwater basins and a large part of the uplands near the city of Pismo Beach, located just north of the Santa Maria Valley groundwater basin (California Department of Water Resources, 2004b,c,d,e). The Uplands study area also included uplifted areas just outside of the eastern Santa Maria Valley, southern San Antonio Creek Valley, and eastern Santa Ynez River Valley groundwater basins (fig. 3).

The geologic formations that were used to categorize the Basins study area are the Careaga Sand formation and unnamed dune sand formations. The Careaga Sand formation is of Pliocene age and is made up of unconsolidated fine to medium grained marine sand and occurs in the Los Osos Valley, Santa Maria River Valley, San Antonio Creek Valley, and Santa Ynez River Valley groundwater basins (California Department of Water Resources, 2004a,c,d,e). Dune sand formations of Pleistocene age occur in the Los Osos Valley and San Antonio Creek Valley groundwater basins and dune sand of Holocene and Pleistocene age are present in the Santa Maria Valley groundwater basin (California Department of Water Resources, 2004a,c,d).

The geologic formations that were used to categorize the Uplands study area are the alluvial terrace deposits and the Orcutt Formation. The alluvial terrace deposits are of Pleistocene age, and consist of unconsolidated sand, gravel, silt, and clay, and located in the San Luis Obispo and the Santa Ynez River Valley groundwater basins and in the uplands located just outside of the Santa Maria Valley groundwater basin (California Department of Water Resources, 2004b,c,e). The Pleistocene age Orcutt Formation, which may be classified as a terrace deposit, consists of unconsolidated clay and sand interbedded with gravel and primarily of fluvial origin (California Department of Water Resources, 2004c,d,e).

The SCRC has three major faults zones (the Los Osos, Edna, and Santa Maria River), each acting as a barrier to the lateral movement of groundwater (California Department of Water Resources, 2004a,b,c,d) (fig. 2). There also is a subsurface restrictive structure within the San Antonio Creek Valley groundwater basin that creates the wetland known as Barka Slough (California Department of Water Resources, 2004c) (fig. 2).

Groundwater recharge in the SCRC occurs from a mixture of ambient recharge (percolation of precipitation, irrigation waters, and seepage from streams and rivers), subsurface inflow, and engineered recharge (urban and agricultural return-water, treated wastewater, and lakes) (California Department of Water Resources, 2004a,b,c,d,e).

\section{Methods}

Methods used for the GAMA Priority Basins Project were selected to achieve the following objectives: (1) design a sampling plan for suitable statistical representation, (2) collect samples in a consistent manner, (3) analyze samples using proven and reliable laboratory methods, (4) assure the quality of the groundwater data, and (5) maintain data securely and with relevant documentation. The appendix contains detailed descriptions of the sample-collection protocols and analytical methods, the quality-assurance plan, and the results of analyses of quality-control samples.

\section{Study Design}

The wells selected for sampling in this study reflect the combination of two well-selection strategies. Fiftyfive "grid" wells were selected to provide a statistically unbiased, spatially distributed assessment of the quality of groundwater resources used for public drinking-water supply, while 15 additional "understanding" wells were selected to provide greater sampling density in several areas to aid in understanding of specific groundwater quality issues in the study unit.

The spatially distributed wells were selected using a randomized grid-based method (Scott, 1990). The randomized grid-based method divides the study unit into equal area grid cells; however, geographic features may force a grid cell to be divided into multiple pieces in order to obtain the designated coverage area for each cell. For instance, a portion of a grid cell may be located on either side of a mountain range, but the grid cell is still considered one grid cell. The objective for the SCRC study was to sample at least one public-supply well per grid cell. 


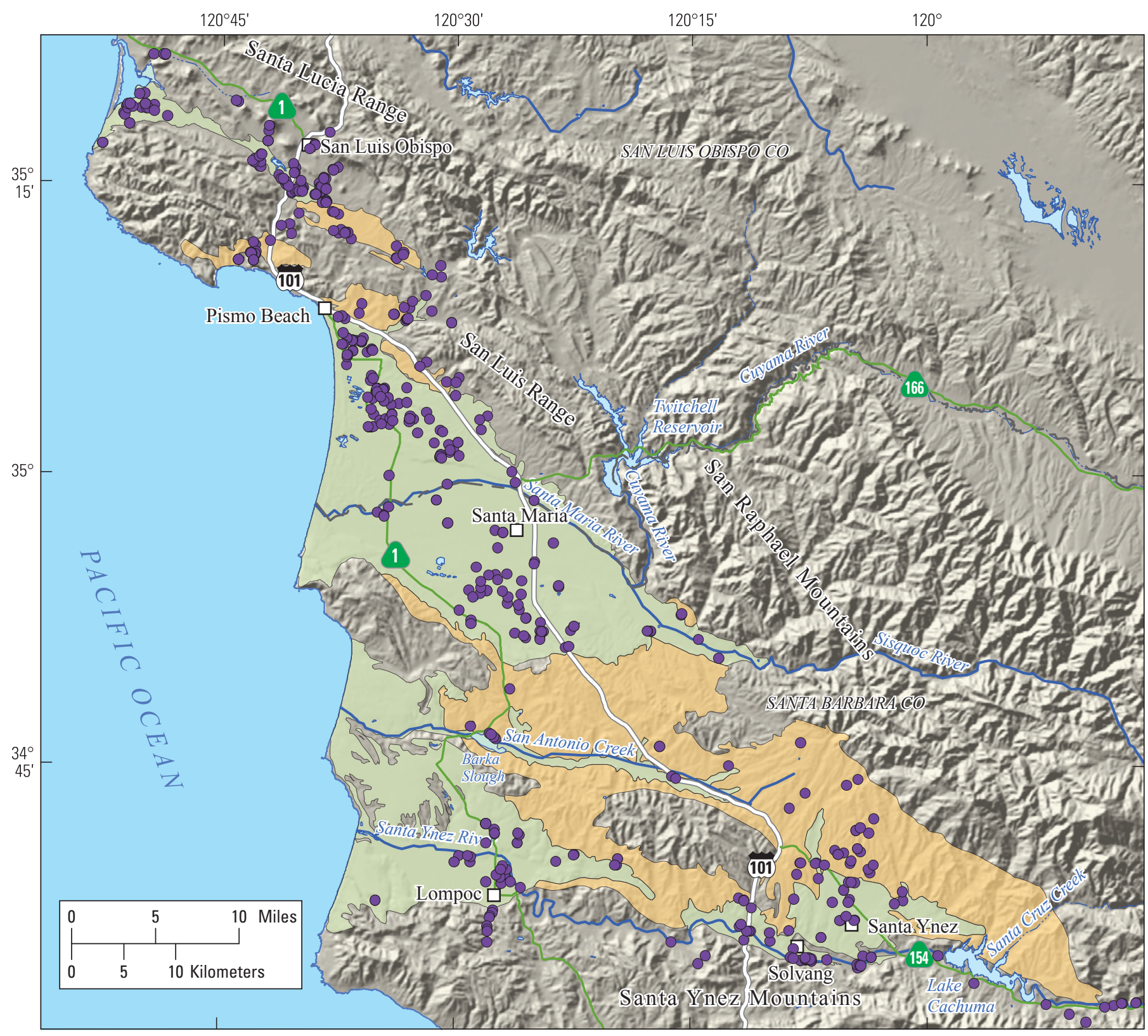

Shaded relief derived from U.S. Geological Survey National Elevation Dataset, 2006. Albers Equal Area Conic Projection

\section{EXPLANATION}

Study area

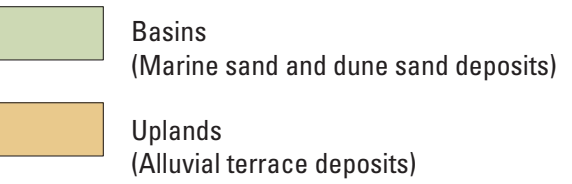

- Public-supply well-With a record in California Department of Public Health (CDPH) Database

(Alluvial terrace deposits)

Figure 3. The South Coast Range-Coastal (SCRC) Groundwater Ambient Monitoring and Assessment (GAMA) study unit showing the boundaries of the Basins and Uplands study areas, the location of public-supply wells with a record in the California Department of Public Health (CDPH) Database, major cities, major roads, topographic features, and hydrologic features. 
The Basins study area was divided into 45 equal area grid cells, approximately $10 \mathrm{mi}^{2}$ (25 square-kilometers $\left.\left[\mathrm{km}^{2}\right]\right)$ in area, with a total of 39 wells sampled within this grid network (fig. 4). Relatively few public-supply wells were in the Uplands study area, and these wells were not evenly distributed. To minimize the number of cells without any wells, only the part of the Uplands study area in close proximity to a public-supply well was included in the gridded area. Locations of public-supply wells listed in the statewide database maintained by the CDPH were plotted and 1.86mi $(3-\mathrm{km})$ radius circles were drawn around each well. The collective area encompassed by the circles was initally divided into fourteen $10-\mathrm{mi}^{2}$ grid cells (fig. 4). Two additional wells that were not public-supply wells, but which had similar construction characteristics, were sampled in the Uplands study area outside of the original grid network to expand the spatial distribution, resulting in a total of 16 wells. A $1.86-\mathrm{mi}$ (3-km) radius circle was drawn around each of the additional wells to increase the size of the Uplands study area from $140 \mathrm{mi}^{2}$ to $160 \mathrm{mi}^{2}$.

In the SCRC, an attempt was made to sample available public-supply wells located within each grid cell. If a grid cell contained more than one public-supply well, each well randomly was assigned a rank. The highest ranking well that met basic sampling criteria (for example, sampling point located prior to treatment or capability to pump for several hours), and for which permission to sample could be obtained, was sampled. If a grid cell contained no accessible publicsupply wells, then other types of wells, such as irrigation, environmental monitoring, industrial, and/or domestic wells, were considered for sampling. An attempt was made to select "alternative" wells with depths and screened intervals similar to those in public-supply wells in the area. In this fashion, one well was selected in each cell to provide a spatially distributed, randomized monitoring network.

The land use in the SCRC is predominantly classified as agricultural, and the locations of the public-supply wells tend to be clustered around the more urbanized areas of the study unit (Volgelmann and others, 2001; Price and others, 2003) (fig. 3). As a result, there were more irrigation wells than public-supply wells available and sampled within the time-frame of the spatially distributed, randomized grid-based assessment of the primary aquifers in the SCRC.

Wells sampled as part of the spatially distributed, randomized grid-cell network are hereinafter referred to as "grid wells". The 55 grid wells sampled in SCRC were named for the study area where they were located by using the prefix "SCRC-B" for the Basins study area and "SCRC-H" for the Uplands study area and by using a suffix numbered in the order of sample collection within each study area (fig. 4).

Fifteen additional, non-randomized wells (hereinafter referred to as "understanding wells") were sampled in the SCRC to collect more information for specific water-quality issues within the study unit. Wells sampled as part of these studies were not included in the statistical characterization of water quality in SCRC because inclusion of these wells would lead to the overrepresentation of some cells. These additional, non-randomized wells were named by using the prefix "SCRC-U" ("U" indicating "understanding") and by using a suffix numbered in the order of sample collection (fig. 4).

In addition, three surface-water samples were collected in the Basins study area in streams near the location of two of the sampled wells (SCRC-B30 and SCRC-U05) in order to better comprehend the interaction between groundwater and surface water in the area. The surface-water samples were named by using the prefix "SCRC-SW" ("SW" indicating "surface water") and by using a suffix numbered in the order of sample collection (fig. 4)

The GAMA alphanumeric identification number for each well and surface-water site, along with the date sampled, sampling schedule, well and surface-water site altitude, well type, and available well-construction information is shown in table 1) (all tables at back of report). Groundwater samples were collected from 31 irrigation wells, 23 public-supply wells, 8 environmental monitoring wells, 5 industrial wells, and 3 domestic wells during the period from May to December 2008.

Well locations and identifications were verified using global positioning system (GPS), 1:24,000-scale USGS topographic maps, comparison with existing well information in USGS and CDPH Databases, and information provided by well owners. Drillers' logs for wells were obtained when available. Well information was recorded by hand on field sheets, and electronically on field laptop computers using the portable computer field forms (PCFF) program designed for USGS sampling. All information was verified and then uploaded into the USGS National Water Information System (NWIS). Well owner and well type information is confidential.

The wells in SCRC were sampled using a tiered analytical approach. All wells were sampled for a standard set of constituents, including volatile organic compounds (VOCs), 1,2,3-TCP, pesticides and pesticide degradates, polar pesticides and metabolites, perchlorate, stable isotopes of hydrogen and oxygen in water, tritium, and dissolved noble gases. The standard set of constituents was termed the "fast" schedule (table 2). Wells on the "slow" schedule were sampled for all constituents on the fast schedule, plus pharmaceuticals, $N$-nitrosodimethylamine (NDMA), trace elements, nutrients, dissolved organic carbon (DOC), major and minor ions, silica, total dissolved solids (TDS), alkalinity, arsenic and iron speciation, gross alpha and gross beta radioactivity, stable isotopes of carbon in dissolved inorganic carbon and carbon-14 abundance (table 2). In addition, some fast and slow wells were included on a "special study" schedule and sampled for stable isotopes of nitrogen and oxygen in dissolved nitrate, stable isotopes of sulfur in dissolved sulfate, and dissolved gases (table 2). The "surface-water" schedule consisted of trace elements, nutrients, major and minor ions, silica, TDS, alkalinity, stable isotopes of hydrogen and oxygen in water, and stable isotopes of nitrogen and oxygen in dissolved nitrate (table 2). 


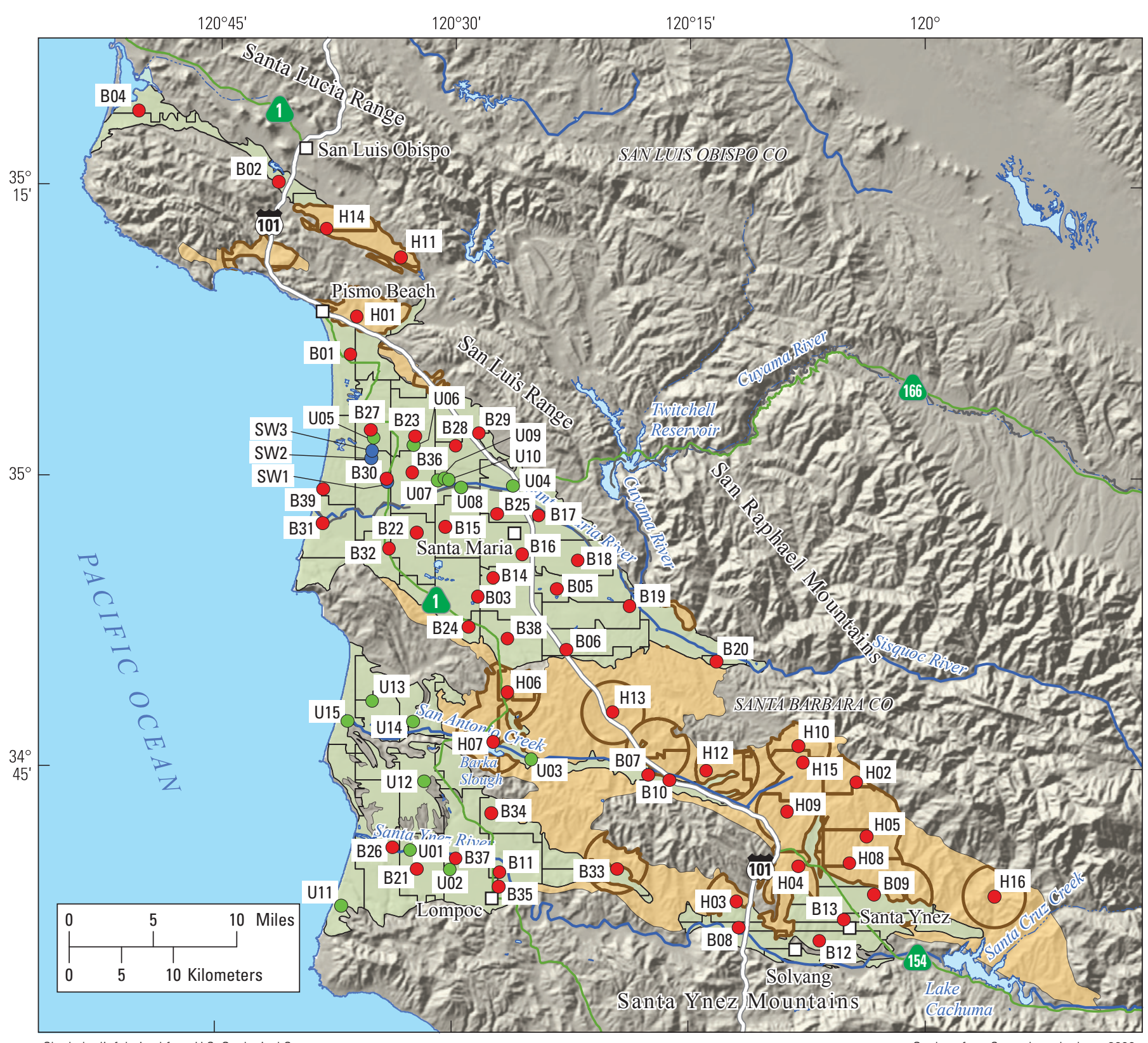

Shaded relief derived from U.S. Geological Survey National Elevation Dataset, 2006. Albers Equal Area Conic Projection

EXPLANATION

Study areas

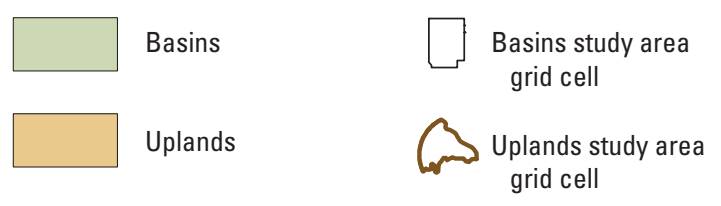
B18
SCRC grid well and identifier
U04 SCRC understanding well and identifier
SW2 O SCRC surface-water
sampling site and identifier
"SCRC" identifier has been omitted from
figure due to spatial concerns

Figure 4. The South Coast Range-Coastal (SCRC) Groundwater Ambient Monitoring and Assessment (GAMA) study unit showing the distribution of the Basins and Uplands study area-grid cells, the location of sampled grid and understanding wells and surface-water sites, major cities, major roads, topographic features, and hydrologic features. 
Fast and slow refer to the time required to sample the well for all analytes on the respective schedules. Two slow or three fast wells generally could be sampled in 1 day. In SCRC, 29 of the wells were sampled on the fast schedule (22 grid and 7 understanding), 29 wells were sampled on the slow schedule (27 grid and 2 understanding), 12 wells were sampled on the fast or slow plus special study schedule (6 grid and 6 understanding), and 3 sites were sampled on the surface-water schedule (table 1).

\section{Sample Collection and Analysis}

Samples were collected in accordance with the protocols established by the USGS National Water Quality Assessment (NAWQA) program (Koterba and others, 1995) and the USGS National Field Manual (U.S. Geological Survey, variously dated). These sampling protocols ensure that representative samples of groundwater are collected at each site and that the samples are collected and handled in ways that minimize the potential for contamination.

Tables $3 \mathrm{~A}-\mathrm{K}$ list the compounds analyzed in each constituent class. Groundwater samples were analyzed for 85 VOCs (table 3A); 63 pesticides and pesticide degradates (table 3B); 60 polar pesticides and metabolites (table 3C); 14 pharmaceutical compounds (table 3D); 3 constituents of special interest (table 3E); 25 trace elements (table 3F); 9 nutrients and DOC (table 3G); 9 major and minor ions, silica, TDS, and alkalinity (table $3 \mathrm{H})$; arsenic and iron species (table 3I); stable isotopes of hydrogen and oxygen in water, stable isotopes of nitrogen and oxygen in dissolved nitrate, stable isotopes of sulfur in dissolved sulfate, stable isotopes of carbon in dissolved inorganic carbon, and 4 radioactive constituents, including tritium and carbon-14 abundance (table 3J); 10 dissolved gases (including noble gases), tritium, and helium stable isotopic ratios (table 3K). The methods used for sample collection and analysis are described in the appendix section titled "Sample Collection and Analysis."

\section{Data Reporting}

The methods and conventions used for reporting the data are described in the appendix section titled "Data Reporting." Twelve constituents analyzed in this study were measured by more than one analytical schedule or more than one laboratory. Four constituents analyzed in this study were measured by more than one method at the USGS National Water Quality Laboratory (NWQL), but only the results from the preferred method are reported (see the appendix section titled "Constituents on Multiple Analytical Schedules"). One constituent (metalaxyl) was measured by two analytical schedules at the NWQL and data from both methods are presented. Three constituents-1,2,3-TCP, arsenic, and iron concentrations - were measured by two different laboratories and both sets of results are reported for these constituents. Tritium activities were measured by two different laboratories but only one set of results are presented in this report.

\section{Quality Assurance}

The quality-assurance and quality-control procedures used for this study followed the protocols used by the USGS NAWQA program (Koterba and others, 1995) and described in the USGS National Field Manual (U.S. Geological Survey, variously dated). The quality-assurance plan followed by the USGS National Water Quality Laboratory (NWQL), the primary laboratory used to analyze samples for this study, is described in Pirkey and Glodt (1998) and Maloney (2005). Quality-control (QC) samples collected in the SCRC study include: blanks, replicates, and matrix and surrogate spikes. QC samples were collected to evaluate potential contamination, as well as bias and variability of the data that may have resulted from sample collection, processing, storage, transportation, and laboratory analysis. Quality-control procedures and quality-control sample results are described in the appendix section titled "Quality Assurance."

\section{Water-Quality Results}

\section{Quality-Control Results}

Results of quality-control analyses (blanks, replicates, matrix spikes, and surrogates) were used to evaluate the quality of the data for the groundwater samples. On the basis of detections in blanks collected for this and previous GAMA Priority Basins Project study units, some detections reported by the laboratory for three organic compounds were considered suspect and, therefore, were removed from the set of groundwater-quality data presented in this report (see table A3 and additional discussion in the appendix). Results from the replicates confirm that the procedures used to collect and analyze the samples were consistent. Variability for nearly 100 percent of the replicate pairs for constituents detected in samples was within the acceptable limits of 10 percent relative and/or standard deviation (tables A4A-C). Median matrixspike recoveries for 33 of the 211 organic and special interest constituents analyzed were lower than the acceptable limit of 70 percent (tables 3B$, 3 \mathrm{C}, \mathrm{A} 5 \mathrm{~B}$, and $\mathrm{A} 5 \mathrm{C}$ ), which may indicate that these constituents might not have been detected in some samples if they were present in the samples at concentrations near the laboratory reporting levels (LRLs). The qualitycontrol results are described in the appendix section titled "Quality-Control Results." 


\section{Comparison Thresholds}

Concentrations of constituents detected in groundwater samples were compared with CDPH and USEPA regulatory and non-regulatory drinking-water health-based thresholds and thresholds established for aesthetic purposes (California Department of Public Health, 2008a,b; U.S. Environmental Protection Agency, 2008a,b). The chemical data presented in this report are meant to characterize the quality of the untreated groundwater within the primary aquifers of SCRC and are not intended to represent the treated drinking water delivered to consumers by water purveyors. The chemical composition of treated drinking water may differ from untreated groundwater because treated drinking water may be subjected to disinfection, filtration, mixing with other waters, and/or exposure to the atmosphere prior to its delivery to consumers. Comparisons of untreated groundwater to thresholds are for illustrative purposes only and are not indicative of compliance or noncompliance with drinkingwater regulations. The following thresholds were used for comparisons:

- MCL-Maximum Contaminant Level. Legally enforceable standards that apply to public-water systems and are designed to protect public health by limiting the levels of contaminants in drinking water. MCLs established by the USEPA are the minimum standards with which States are required to comply and individual States may choose to set more stringent standards. CDPH has established MCLs for additional constituents not regulated by the USEPA, as well as lowered the threshold concentration for a number of constituents with MCLs established by the USEPA. In this report, a threshold set by the USEPA and adopted by CDPH is labeled "MCL-US", and one set by CDPH that is more stringent than the MCL-US is labeled "MCL-CA". CDPH is notified when constituents are detected at concentrations greater than an MCL-US or MCL-CA thresholds in samples collected for the GAMA Priority Basins Project, but these detections do not constitute violations of $\mathrm{CDPH}$ regulations.

- AL-Action Level. Legally enforceable standards that apply to public water systems and are designed to protect public health by limiting the levels of copper and lead in drinking water. Detections of copper or lead greater than the action-level thresholds trigger requirements for mandatory water treatment to reduce the corrosiveness of water to water pipes. The action levels established by the USEPA and CDPH are the same; thus, the thresholds are labeled "AL-US" in this report.
- SMCL-Secondary Maximum Contaminant Level. Non-enforceable standards applied to constituents that affect the aesthetic qualities of drinking water, such as taste, odor, and color, or the technical qualities of drinking water, such as scaling and staining. Both the USEPA and CDPH define SMCLs, but unlike MCLs, SMCLs established by CDPH are not required to be at least as stringent as those established by USEPA. SMCLs established by CDPH are used in this report (SMCL-CA) for all constituents that have SMCL-CA values. The SMCL-US is used for $\mathrm{pH}$ because no SMCL-CA has been defined.

- NL-Notification Level. Health-based notification levels established by CDPH for some of the constituents in drinking water that lack MCLs (NLCA). If a constituent is detected at concentrations greater than its NL-CA, California State law requires timely notification of local governing bodies and recommends consumer notification.

- HAL - Lifetime Health Advisory Level. The maximum concentration of a constituent at which its presence in drinking water is not expected to cause any adverse carcinogenic effects for a lifetime of exposure. HALs are established by the USEPA (HAL-US) and are calculated assuming consumption of $2 \mathrm{~L}$ ( 2.1 quarts) of water per day over a 70 -year lifetime by a $70-\mathrm{kg}$ (154-lb) adult and that 20 percent of a person's exposure comes from drinking water.

- RSD5-Risk-Specific Dose. The concentration of a constituent in drinking water corresponding to an excess estimated lifetime cancer risk of 1 in 100,000. RSD5 is an acronym for risk-specific dose at $10^{-5}$. RSD5s are calculated by dividing the $10^{-4}$ cancer risk concentration established by the USEPA by 10 (RSD5-US).

For constituents with MCLs, detections in groundwater samples were compared to the MCL-US or MCL-CA. Constituents with SMCLs were compared with the SMCL-CA. For chloride, sulfate, specific conductance, and TDS, CDPH defines a "recommended" and an "upper" SMCL-CA; detections of these constituents in groundwater samples were compared with both levels. The SMCL-US for these constituents corresponds to the recommended SMCL-CA. Detected concentrations of constituents that lack an MCL or SMCL were compared to the NL-CA. For constituents that lack an MCL, SMCL, or NL-CA, detected concentrations were compared with the HAL-US. For constituents that lack an MCL, SMCL, NL-CA, or HAL-US, detected concentrations were compared with the RSD5-US. Note 
that if a constituent has more than one type of established threshold, using this hierarchy to select the comparison threshold will not necessarily result in selection of the threshold with the lowest concentration. For example, zinc has an SMCL-CA of 5,000 $\mu \mathrm{g} / \mathrm{L}$ and a HAL-US of 2,000 $\mu \mathrm{g} / \mathrm{L}$, and the comparison threshold selected by this hierarchy is the SMCL-CA. The comparison thresholds used in this report are listed in tables $3 \mathrm{~A}-\mathrm{K}$ for all constituents and in tables 4-14 for constituents detected in groundwater samples from SCRC. Not all constituents analyzed for this study have established thresholds available. Detections of constituents at concentrations greater than the selected comparison threshold are marked with asterisks in tables 4, 5, 8-11, and 13 .

\section{Groundwater-Quality Data}

Results from analyses of untreated groundwater samples from SCRC are presented in tables 4-14. These results are separated into the two study areas that make up the SCRC (Basins grid wells and Uplands grid wells), the understanding well samples, and the surface-water samples. Groundwater samples collected in SCRC were analyzed for 298 constituents; 181 of those constituents were not detected in any of the samples, 96 constituents were detected, and results for 21 constituents have not been received or are being evaluated and are not presented in this report (tables $3 \mathrm{~A}-\mathrm{K}$ ). For organic and special interest (perchlorate) constituent classes that were analyzed at all grid wells, the results tables include the following summary statistics for all 55 SCRC grid wells and for the grid wells in each study area (Basins and Uplands): the number of wells at which each analyte was detected, the frequency at which it was detected (in relation to the number of grid wells in the study area), and the total number of constituents detected at each well. For the inorganic, isotopic, and radioactive constituent classes, the summary tables include all wells, constituents, and samples analyzed. Results from the understanding wells are presented in the tables, but these results were excluded from the detection frequency calculations to avoid statistically over-representing the areas near the understanding wells. The surface-water sample results are presented in tables $4, \underline{8}, \underline{9}, \underline{10}$, and $\underline{12}$.

Field water-quality indicators measured in the field and at the NWQL are included in table 4. The results of groundwater and/or surface-water analyses organized by compound classes are presented in tables 5-14:

- Organic constituents

- Volatile organic compounds (VOC) (table 5)

- Pesticides and pesticide degradates (table 6A)

- Polar pesticides and metabolites (table 6B)

- Perchlorate (table 7)
- Inorganic constituents

- Trace elements (table 8)

- Nutrients and dissolved organic carbon (DOC) (table 9)

- Major and minor ions, silica, and total dissolved solids (TDS) (table 10)

- Arsenic and iron speciation (table 11)

- Isotopic tracers (table 12)

- Dissolved gases (table 13)

- Radioactive constituents (table 14)

Results for pharmaceutical compounds are not presented in this report; they will be included in a subsequent publication. In addition, as of the publishing date of this data report, the results of analyses of samples collected in SCRC for the stable-isotope ratios of sulfur in dissolved sulfate, dissolved noble gases, and helium isotope ratios were not available; results will be presented in a subsequent publication.

\section{Field Water-Quality Indicators}

Field and laboratory measurements of dissolved oxygen, $\mathrm{pH}$, specific conductance, alkalinity, and associated parameters (turbidity, water temperature, and bicarbonate and carbonate concentrations) are presented in table 4. Alkalinity, dissolved oxygen, and bicarbonate and carbonate concentrations are used as indicators of natural processes that affect water chemistry. Specific conductance is the measure of electrical conductivity of the water and is proportional to amount of total dissolved solids in the water. The $\mathrm{pH}$ value indicates the acidity of the water.

Field specific-conductance values for 69 percent of SCRC grid wells (38 of 55 wells: 30 of 39 Basins grid wells and 8 of 16 Uplands grid wells) were greater than the recommended SMCL-CA of $900 \mu \mathrm{S} / \mathrm{cm}$. Field specific-conductance values for six of the Basins grid wells also were greater than the upper threshold of $1,600 \mu \mathrm{S} / \mathrm{cm}$.

Field specific-conductance values for 10 of the 15 understanding wells were greater than the recommended SMCL-CA. In addition, values for 7 of the 10 understanding wells and all surface-water samples were greater than the SMCL-CA upper threshold.

Field $\mathrm{pH}$ values for 2 of the 55 grid wells sampled (2 Basins grid wells) in the SCRC were outside of the SMCL-US range for $\mathrm{pH}$. Field $\mathrm{pH}$ values for 3 of the 15 understanding wells were outside of the SMCL-US range (table 4). (Laboratory $\mathrm{pH}$ values may be dissimilar to field $\mathrm{pH}$ values because the $\mathrm{pH}$ of groundwater may change upon removal from the ambient environment and exposure to the atmosphere.) 
Field turbidity values for all three surface-water samples were greater than the recommended SMCL-CA threshold of 5 NTRUs (table 4 ).

\section{Organic Constituents}

Volatile organic compounds (VOC) may be present in paints, solvents, fuels, fuel additives, refrigerants, fumigants, and disinfected water, and are characterized by their tendency to evaporate. VOCs generally persist longer in groundwater than in surface water because groundwater is isolated from the atmosphere.

Of the 85 VOCs analyzed, 14 were detected in SCRC groundwater samples; all detections in grid well samples were less than health-based thresholds (table 5). One or more VOCs were detected in 18 of the 55 SCRC grid wells (about 33 percent detection frequency) sampled. In the Basins study area, VOCs were detected in approximately 33 percent of the 39 grid wells. VOCs that were detected in more than 10 percent of the Basins study area grid wells were chloroform (trichloromethane), perchloroethene (PCE, tetrachloroethene), dichlorodifluoromethane (CFC-12), and trichlorofluoromethane (CFC-11). In the Uplands study area, VOCs were detected in approximately 31 percent of the 16 grid wells. Chloroform (trichloromethane) was the only VOC detected in more than 10 percent of the Uplands study area grid wells. One or more VOCs were detected in 2 of the 15 understanding wells in the SCRC. Cis-1,2-dichloroethene (cis-1,2-DCE) and vinyl chloride (chloroethene) were detected at concentrations greater than the corresponding MCL-CA in one understanding well (table 5).

Pesticides include herbicides, insecticides, and fungicides, and are used to control weeds, insects, fungi, and other pests in agricultural, urban, and suburban settings. Of the 63 pesticides and pesticide degradates analyzed at 69 wells (54 grid and 15 understanding) in the SCRC study, 11 pesticides were detected in groundwater samples; all detections were well below health-based thresholds (table 6A). One or more pesticide compounds were detected in 15 of the 54 SCRC grid wells (about 28 percent detection frequency) sampled. In the Basins study area, pesticides and pesticide degradates were detected in approximately 34 percent of the 38 grid wells. The herbicides atrazine and deethylatrazine (a degradate of atrazine) were detected in more than 10 percent of the Basins grid well samples. Atrazine and deethylatrazine are among the Nation's most commonly detected pesticide compounds in groundwater (Gilliom and others, 2006). In the Uplands study area, pesticides and pesticide degradates were detected in approximately 13 percent of the 16 grid wells. No pesticide and pesticide degradate was detected in more than 10 percent of the grid well samples in the Uplands study area. One or more pesticide compounds were detected in 5 of the

15 understanding wells sampled (table 6A).

In addition, groundwater samples for 60 polar pesticides and metabolites were analyzed at 69 wells (54 grid and
15 understanding) in the SCRC study. Four polar pesticides and metabolites were detected and all detections were well below health-based thresholds (table 6B). In the Basins study area, polar pesticides and metabolites were detected in 3 of the 38 grid wells sampled. No polar pesticide and metabolites were detected in any of the 16 grid wells in the Uplands study area. One polar pesticide and one metabolite were detected in a single understanding well sample (table 6B).

\section{Constituents of Special Interest}

Perchlorate, NDMA, and 1,2,3-TCP are constituents of special interest in California because they may adversely affect water quality and recently have been detected in water supplies (California Department of Public Health, 2008b). Perchlorate was analyzed for at all 70 wells in SCRC and was detected in 60 percent of the grid wells ( 33 of 55 wells: 28 of 39 Basin grid wells and 5 of 16 Upland grid wells). Perchlorate was not measured at concentrations greater than the MCL-CA in any of the grid or understanding wells in SCRC (table 7). 1,2,3-TCP was sampled for at all 70 wells and NDMA at the 39 slow wells in the SCRC, and both analytes were not detected in any wells. As a result, NDMA and 1,2,3-TCP are not included in table 7.

\section{Inorganic Constituents}

Unlike the organic constituents and the constituents of special interest, most of the inorganic constituents are naturally present in groundwater, although their concentrations may be influenced by human activities. Inorganic constituents were sampled on the slow sampling schedule (32 grid and 7 understanding wells) in SCRC, and trace elements, nutrients, major and minor ions, silica, TDS, and alkalinity were sampled for on the surface-water schedule. Three additional nutrient samples were collected at the special study wells, coinciding with collection of samples analyzed for stable isotopes of nitrogen and oxygen in dissolved nitrate from these wells.

Twenty-two of 25 trace elements analyzed in this study have regulatory health-based or non-regulatory aesthetic thresholds (table 3F). Of the 18 trace elements with healthbased thresholds, concentrations of most detections of the trace elements in the SCRC grid wells were less than these thresholds (table 8). The exceptions were a few detections of arsenic and molybdenum greater than thresholds. An arsenic concentration greater than the USEPA maximum contaminant level (MCL-US) of $10 \mu \mathrm{g} / \mathrm{L}$ was detected in 1 of the 16 basins grid well samples analyzed for trace elements. Arsenic concentrations greater than the MCL-US were detected in 2 of the 16 Uplands grid wells analyzed for trace elements. Molybdenum concentrations greater than the USEPA lifetime health advisory level (HAL-US) of $40 \mu \mathrm{g} / \mathrm{L}$ were detected in eight Uplands grid wells (table 8). 
Trace elements were sampled for at seven slow understanding wells in SCRC. Molybdenum concentrations greater than the HAL-US threshold were detected in one understanding well (table 8).

Nutrients (nitrogen and phosphorus) and dissolved organic carbon (DOC) present in groundwater can affect biological activity in aquifers and in surface-water bodies that receive groundwater discharge. Inorganic nitrogen may be present in the form of ammonia, nitrite, or nitrate depending on the oxidation-reduction state of the groundwater. High concentrations of nitrate can adversely affect human health, particularly the health of infants.

Concentrations of ammonia, nitrate, nitrite, and phosphorus measured in samples from 17 grid wells in the Basins study area and 16 grid wells in the Uplands study area were mostly less than health-based thresholds. Nitrite plus nitrate, as nitrogen $\left(\mathrm{NO}_{2}{ }^{-}+\mathrm{NO}_{3}{ }^{-}\right)$concentrations greater than the MCL-US of $10 \mathrm{mg} / \mathrm{L}$ were detected in three Basins grid wells (table 9). Detections of $\mathrm{NO}_{2}{ }^{-}+\mathrm{NO}_{3}{ }^{-}$greater than the MCL-US also occurred in three of nine understanding wells, and all three surface-water samples in SCRC (table 9).

The levels of certain trace elements, major-ion composition, and total dissolved solids (TDS) content in groundwater affect the aesthetic properties of water, such as taste, color, and odor, and the technical properties of water, such as scaling and staining. Although there are no adverse health effects directly associated with these properties, they may reduce consumer satisfaction with the water or may have economic effects. CDPH has established non-enforceable thresholds (SMCL-CA) that are based on aesthetic properties rather than on human-health concerns for several trace elements, the ions chloride and sulfate, and TDS.

Iron and manganese are trace elements whose concentrations are affected by the oxidation-reduction state of the groundwater. Precipitation of minerals containing iron or manganese may cause orange, brown, or black staining of surfaces. Iron, manganese, TDS, chloride, and sulfate were sampled for at 16 grid wells in the Basins study area, 16 grid wells in the Uplands study area, 7 understanding wells, and the three surface-water sites in the SCRC.

Iron concentrations greater than the SMCL-CA of $300 \mu \mathrm{g} / \mathrm{L}$ were detected in three Basins and two Uplands study area grid wells (table 8).

Manganese concentrations greater than the SMCL-CA of $50 \mu \mathrm{g} / \mathrm{L}$ were detected in nine grid wells; these detections occurred in six grid wells in the Basins study area and three grid wells in the Uplands study area. In the SCRC, manganese concentrations greater than the SMCL-CA were detected in one of seven understanding wells (table 8).

Chloride concentrations greater than the recommended SMCL-CA threshold of $250 \mathrm{mg} / \mathrm{L}$ were detected in one Basins grid well (table 10).
Sulfate concentrations greater than the recommended SMCL-CA threshold of $250 \mathrm{mg} / \mathrm{L}$ were detected in 14 grid well samples in SCRC, including 12 Basin grid wells and 2 Uplands grid wells (table 10). Sulfate concentrations greater than the upper SMCL-CA threshold of $500 \mathrm{mg} / \mathrm{L}$ were detected in 3 Basins grid wells (table 10). Sulfate concentrations greater than the recommended SMCL-CA threshold of $250 \mathrm{mg} / \mathrm{L}$ were detected in four understanding wells and all three surface-water samples. Sulfate concentrations greater than the upper SMCL-CA threshold of $500 \mathrm{mg} / \mathrm{L}$ were detected in one of three surface-water samples (table 10).

TDS concentrations greater than the recommended SMCL-CA threshold of $500 \mathrm{mg} / \mathrm{L}$ were detected in 25 grid wells, including 14 Basins grid wells and 11 Uplands grid wells (table 10). TDS concentrations greater than the upper SMCL-CA threshold of $1,000 \mathrm{mg} / \mathrm{L}$ were detected in 5 of 14 Basins grid wells. TDS concentrations greater than the upper SMCL-CA were detected in four SCRC understanding wells and all three surface-water samples (table 10).

Arsenic and iron occur in different species depending on the oxidation-reduction state of the groundwater. The oxidized and reduced species have different solubilities in groundwater and may have different effects on human health. The relative proportions of the oxidized and reduced species of each element can be used to aid in interpretation of the oxidationreduction state of the aquifer. Concentrations of total arsenic and iron and the concentration of either the reduced or the oxidized species of each element are reported in table 11. The concentration of the other species can be calculated by difference. The concentrations of arsenic and iron reported in table 11 may be different than those reported in table 8 because different analytical methods were used (see the appendix section titled "Constituents on Multiple Analytical Schedules"). The concentrations reported in table 8 are considered to be more accurate. Some of the arsenic and iron species analyses were not completed in time for inclusion in this report; complete results will be presented in a subsequent publication.

\section{Isotopic Tracers and Dissolved Gases}

The isotopic ratios of hydrogen and oxygen in water, nitrogen and oxygen in dissolved nitrate, sulfur in dissolved sulfate, and carbon in dissolved inorganic carbon, tritium activity, carbon-14 abundance, and the concentrations of dissolved gases (including noble gases) may be used as tracers of hydrologic processes (Clark and Fritz, 1997).

The isotopic ratios of hydrogen and oxygen in water (table 12) aid in the interpretation of the sources of groundwater recharge. These stable isotopic ratios reflect the altitude, latitude, and temperature of precipitation and also the extent of evaporation of the water in surface-water bodies or soils prior to infiltration into the aquifer. 
Stable-isotope ratios of sulfur in dissolved sulfate can be used to aid in the characterization of the groundwater system by determining the source of dissolved sulfur species and/or understanding chemical reactions occurring in groundwater systems, such as the microbial reduction of sulfate or the oxidation of sulfide. Measurements of isotopic ratios of sulfur in dissolved sulfate were not completed in time for inclusion in this report; results will be presented in a subsequent publication.

Stable-isotope ratios of nitrogen and oxygen in dissolved nitrate (table 12) can be used to aid in interpretation of sources and processes affecting this solute in aquifers.

Tritium activities (table 12), helium isotope ratios, and carbon-14 abundance (table 12) also provide information about the age (time since recharge) of groundwater. Tritium is a short-lived radioactive isotope of hydrogen that is incorporated into the water molecule. Low levels of tritium are produced continuously by interaction of cosmic radiation with the Earth's atmosphere and a large amount of tritium was produced as a result atmospheric testing of nuclear weapons between 1952 and 1963. Thus, concentrations of tritium above background generally indicate the presence of water recharged since the early 1950s. Helium isotope ratios are used in conjunction with tritium concentrations to estimate ages for young groundwater. Helium isotope ratio analyses were not completed in time for inclusion in this report; results will be presented in a subsequent publication.

Carbon-14 (table 12) is a radioactive isotope of carbon. Low levels of carbon-14 are produced continuously by interaction of cosmic radiation with the Earth's atmosphere, and incorporated into atmospheric carbon dioxide. Carbon dioxide dissolves in precipitation, surface water, and groundwater exposed to the atmosphere, thereby entering the hydrologic cycle. Because carbon-14 decays with a half-life of approximately 5,700 years, low activities of carbon- 14 relative to modern values, generally indicate a presence of groundwater that is several thousand years old.

Concentrations of dissolved gases (including noble gases) are used to estimate the conditions of groundwater recharge, particularly the temperature of the recharge water. Dissolved gases (including noble gases) dissolve in water that is in contact with the atmosphere, and the solubilities of the different gas species vary with temperature. Results for analyses of dissolved gases are presented in table 13. Dissolved noble gas analyses were not completed in time for inclusion in this report; results will be presented in a subsequent publication.

Of the isotopic tracer constituents analyzed for this study, tritium is the only one with a health-based threshold. All measured tritium activities in samples from SCRC wells were more than three orders of magnitude less than the MCL-CA threshold (table 12).

\section{Radioactive Constituents}

Radioactivity is the release of energy or energetic particles during changes in the structure of the nucleus of an atom. Most radioactivity in groundwater comes from decay of naturally occurring isotopes of uranium and thorium that are present in minerals in the sediments or fractured rocks of the aquifer. Both uranium and thorium decay in a series of steps eventually forming stable isotopes of lead (Soddy, 1913; Faure and Mensing, 2005). In each step in the decay series, one radioactive element turns into a different radioactive element by emitting an alpha or a beta particle from its nucleus. The alpha and beta particles emitted during radioactive decay are hazardous to human health because these energetic particles may damage cell DNA and may increase the risk of getting cancer.

Activity often is used instead of concentration for reporting the presence of radioactive constituents. Activity of radioactive constituents in groundwater is measured in units of picocuries per liter $(\mathrm{pCi} / \mathrm{L})$, and $1 \mathrm{pCi}$ is approximately equal to two atoms decaying per minute. The number of atoms decaying is equal to the number of alpha or beta particles emitted.

The 39 slow samples in SCRC were analyzed for gross alpha and gross beta radioactivity. Activities for all samples from the 32 grid wells were less than established health-based thresholds. Activities of gross alpha radioactivity (72-hour count) greater than the MCL-US of $15 \mathrm{pCi} / \mathrm{L}$ were measured in one understanding well (of seven) (table 14). Five of the radioactive analytes (three gross alpha and two gross beta, 72-hour counts) were counted after the 72-hour time period at the laboratory. A delay in the counting by the laboratory may result in lower activities than may have been observed for these analytes if the count had been preformed within the 72-hour time period; the results for these five analytes are footnoted in table 14 .

\section{Future Work}

Subsequent reports will be focused on assessment of the data presented in this report using a variety of statistical, qualitative, and quantitative approaches to evaluate the natural and human factors affecting groundwater quality in SCRC. Water-quality data contained in the CDPH Databases will be compiled, evaluated, and used in combination with the data that are presented in this report. 


\section{Summary}

Groundwater quality in the approximately 766-squaremile South Coast Range-Coastal (SCRC) study unit was investigated from May to December 2008, as part of the Priority Basins Project of the Groundwater Ambient Monitoring and Assessment (GAMA) Program. The GAMA Priority Basins Project was developed in response to Legislative mandates (Supplemental Report of the 1999 Budget Act 1999-00 Fiscal Year; and, the GroundwaterQuality Monitoring Act of 2001 [Sections 10780-10782.3 of the California Water Code, Assembly Bill 599]) to assess and monitor the quality of groundwater in California and is being conducted by the U.S. Geological Survey (USGS) in cooperation with the California State Water Resources Control Board (SWRCB). The SCRC study unit was the 25 th study unit to be sampled as part of the GAMA Priority Basins Project.

The GAMA SCRC study unit was designed to provide a spatially unbiased assessment of untreated groundwater quality in the primary aquifer systems and to facilitate statistically consistent comparisons of untreated groundwater quality throughout California. The primary aquifer systems (hereinafter referred to as primary aquifers) are defined as as that part of the aquifer corresponding to the perforation interval of wells listed in the California Department of Public Health (CDPH) database for the SCRC study unit. The quality of groundwater in shallow or deep water-bearing zones may differ from that in the primary aquifers; shallow groundwater may be more vulnerable to surficial contamination.

The SCRC study unit is located in the southwestern part of the South Coast Ranges hydrologic province and includes five groundwater basins defined by the California Department of Water Resources. The SCRC study unit included assessment of the groundwater quality from 70 wells in Santa Barbara and San Luis Obispo Counties, California. Fifty-five of the wells were selected using a randomized grid approach to achieve statistically unbiased representation of groundwater used for public drinking-water supplies. Fifteen of the wells were selected to provide additional sampling density to aid in understanding processes affecting groundwater quality. In addition to the 70 wells sampled, 3 surface-water samples were collected in streams near 2 of the sampled wells in order to better comprehend the interaction between groundwater and surface water in the area.

Groundwater samples were analyzed for field waterquality indicators, organic and special interest constituents, naturally occurring inorganic constituents, and radioactive constituents. Naturally occurring isotopes and dissolved gases (including noble gases) also were measured to provide a dataset that will be used to help interpret the sources and ages of the sampled groundwater. In total, 298 constituents and field water-quality indicators were investigated for this study.
This report describes the sampling, analytical, and qualityassurance methods used in the study and presents the results of the chemical analyses of the groundwater samples.

This study did not attempt to evaluate the quality of drinking water delivered to consumers; after withdrawal from the ground, water typically is treated, disinfected, and blended with other waters to maintain acceptable water quality. Regulatory thresholds apply to treated water that is served to the consumer, not to untreated groundwater. However, to provide some context for the results, concentrations of constituents measured in the untreated groundwater were compared with regulatory and non-regulatory health-based thresholds established by the U.S. Environmental Protection Agency (USEPA) and CDPH and non-regulatory thresholds established for aesthetic concerns by CDPH.

All detections of organic constituents in samples from the 55 SCRC grid wells were less than health-based thresholds. In addition, all detections of organic constituents in samples from the 15 understanding wells were less than healthbased thresholds with the exception of the volatile organic compounds (VOC) cis-1,2-dichloroethene (cis-1,2-DCE) and vinyl chloride (chloroethene) detected at concentrations greater than the corresponding CDPH maximum contaminant level (MCL-CA) in one understanding well.

Results from SCRC grid wells showed that most detections of trace elements and nutrients in samples were less than health-based thresholds. Exceptions include three detections of arsenic and three detections of nitrite plus nitrate as nitrogen $\left(\mathrm{NO}_{2}{ }^{-}+\mathrm{NO}_{3}{ }^{-}\right)$greater than the USEPA maximum contaminant level (MCL-US) and eight detections of molybdenum greater than the USEPA lifetime health advisory level (HAL-US). All detections of gross alpha and gross beta radioactivity in SCRC grid wells were less than health-based thresholds.

Concentrations for most samples from 32 SCRC grid wells collected for trace elements and major ions measured less than the non-enforceable thresholds set for aesthetic concerns. Iron concentrations greater than the $\mathrm{CDPH}$ secondary maximum contaminant level (SMCL-CA) of $300 \mu \mathrm{g} / \mathrm{L}$ (micrograms per liter) were detected in five grid wells. Manganese concetrations greater than the SMCL-CA of $50 \mu \mathrm{g} / \mathrm{L}$ were detected in nine grid wells and chloride concentrations greater than the recommended SMCL-CA threshold of $250 \mathrm{mg} / \mathrm{L}$ (milligrams per liter) were measured in one grid well. Sulfate concentrations greater than the recommended SMCL-CA threshold of $250 \mathrm{mg} / \mathrm{L}$ were measured in 14 grid wells and 3 of these wells also were greater than the upper SMCL-CA threshold of $500 \mathrm{mg} / \mathrm{L}$. TDS concentrations greater than the SMCL-CA recommended threshold were measured in 25 grid wells and concentrations in 5 of these wells also were greater than the SMCL-CA upper threshold (SMCL-CA threshold for TDS has a 
recommended value of $500 \mathrm{mg} / \mathrm{L}$ and an upper threshold value of $1,000 \mathrm{mg} / \mathrm{L})$.

Results from the understanding wells in the SCRC study unit showed there were three detections of nitrite plus nitrate as nitrogen $\left(\mathrm{NO}_{2}{ }^{-}+\mathrm{NO}_{3}{ }^{-}\right)$greater than the MCL-US and one detection of molybdenum measured greater than the HAL-US. Manganese concentrations greater than the SMCL-CA threshold $50 \mu \mathrm{g} / \mathrm{L}$ were measured in one understanding wells and sulfate concentrations greater than the recommended SMCL-CA threshold of $250 \mathrm{mg} / \mathrm{L}$ were measured in four understanding wells. TDS concentrations greater than the SMCL-CA recommended lower threshold were measured in six understanding wells sampled for TDS and concentrations also were greater than the upper threshold in four of these wells.

All results from the three surface-water samples in the SCRC study unit were less than health-based thresholds with the exception of nitrite plus nitrate as nitrogen $\left(\mathrm{NO}_{2}{ }^{-}+\mathrm{NO}_{3}{ }^{-}\right)$; concentrations were greater than the MCL-US in all three samples. In addition, concentrations of all trace elements and most of the major ions in the surface-water samples were less than the non-enforceable thresholds set for aesthetic concerns. The exceptions include: sulfate concentrations greater than the recommended SMCL-CA threshold were detected in all three surface-water samples and greater than the upper SMCL-CA threshold in one sample and TDS concentrations greater than the upper SMCL-CA threshold were detected in all three surface-water samples.

\section{Acknowledgments}

The authors thank the following cooperators for their support: the State Water Resources Control Board, California Department of Public Health, California Department of Water Resources, and Lawrence Livermore National Laboratory. We especially thank the well owners and water purveyors for their generosity in allowing the USGS to collect samples from their wells.

\section{References Cited}

American Public Health Association, 1998, Standard methods for the examination of water and wastewater (20th ed.): Washington, D.C., American Public Health Association, American Water Works Association, and Water Environment Federation, p. 3-37-3-43.

Anderson, R.L., 1987, Practical statistics for analytical chemists: New York, Van Nostrand Reinhold Company, Inc., $315 \mathrm{p}$.

Barnes, Ivan, 1964, Field measurement of alkalinity and $\mathrm{pH}$ : U.S. Geological Survey Water-Supply Paper 1535-H, 17 p.
Belitz, Kenneth, Dubrovsky, N.M., Burow, K.R., Jurgens, Bryant, and Johnson, Tyler, 2003, Framework for a groundwater quality monitoring and assessment program for California: U.S. Geological Survey Water-Resources Investigations Report 03-4166, 78 p.

Bennett, G.L., V, Belitz, Kenneth, and Milby Dawson, B.J., 2006, California GAMA Program - Groundwater quality data in the Northern San Joaquin basin study unit, 2005: U.S. Geological Survey Data Series 196, 122 p.

Bennett, P.A., Bennett, G.L., V, and Belitz, Kenneth, 2009, Groundwater quality data for the Northern Sacramento Valley, 2007-Results from the California GAMA program: U.S. Geological Survey Data Series 452, 90 p.

Brenton, R.W., and Arnett, T.L., 1993, Methods of analysis by the U.S. Geological Survey National Water-Quality Laboratory-determination of dissolved organic carbon by UV-promoted persulfate oxidation and infrared spectrometry: U.S. Geological Survey Open-File Report 92-480, $12 \mathrm{p}$.

Bright, D.J., Stamos, C.L., Martin, P., and Nash, D.B., 1992, Ground-water hydrology and quality in the Lompoc area, Santa Barbara County, California, 1987-88: U.S. Geological Survey Water-Resources Investigations Report 91-4172, 77 p.

Burton, C.A., and Belitz, Kenneth, 2008, Groundwater quality data in the Southeast San Joaquin Valley, 20052006-Results from the California GAMA Program: U.S. Geological Survey Data Series 351, 103 p.

Busenberg, Eurybiades, Plummer, L. N., and Bartholomay, R.C., 2001, Estimated age and source of the young fraction of ground water at the Idaho National Engineering and Environmental Laboratory: U.S. Geological Survey WaterResources Investigations Report 01-4265, 144 p.

California Department of Public Health, 2008a, California drinking water-related laws-Drinking water-related regulations, Title 22: California Department of Public Health, accessed August 17, 2009, at http://www.cdph. ca.gov/certlic/drinkingwater/Pages/Lawbook.aspx

California Department of Public Health, 2008b, Drinking water notification levels-Notification levels: California Department of Public Health,, accessed August 17, 2009, at http://www.cdph.ca.gov/certlic/drinkingwater/Pages/ NotificationLevels.aspx

California Department of Water Resources, 2003, California's groundwater update 2003: California Department of Water Resources Bulletin 118, 246 p., accessed September 14, 2009, at http://www.groundwater.water.ca.gov/bulletin 118 
California Department of Water Resources, 2004a, California's groundwater, Los Osos Valley Groundwater Basin: California Department of Water Resources Bulletin 118, accessed September 14, 2009, at http://www.water.ca.gov/ pubs/groundwater/bulletin 118/basindescriptions/3-8.pdf

California Department of Water Resources, 2004b, California's groundwater, San Luis Obispo Valley Groundwater Basin: California Department of Water Resources Bulletin 118, accessed September 14, 2009, at http://www.water.ca.gov/pubs/groundwater/bulletin_118/ basindescriptions/3-9.pdf

California Department of Water Resources, 2004c, California's groundwater, Santa Maria River Valley Groundwater Basin: California Department of Water Resources Bulletin 118, accessed September 14, 2009, at http://www.water.ca.gov/ pubs/groundwater/bulletin_118/basindescriptions/3-12.pdf

California Department of Water Resources, 2004d, California's groundwater, San Antonio Creek Valley Groundwater Basin: California Department of Water Resources Bulletin 118, accessed September 14, 2009, at http://www.water.ca.gov/pubs/groundwater/bulletin 118/ basindescriptions/3-14.pdf

California Department of Water Resources, 2004e, California's groundwater, Santa Ynez River Valley Groundwater Basin: California Department of Water Resources Bulletin 118, accessed September 14, 2009, at http://www.water.ca.gov/ pubs/groundwater/bulletin 118/basindescriptions/3-15.pdf

Carmody, R.W., Plummer, L.N., Busenburg, E., and Coplen, T.B., 1998, Methods for collection of dissolved sulfate and sulfide and analysis of their sulfur isotopic composition: U.S. Geological Survey Open-File Report 97-234, 101 p.

Childress, C.J.O., Foreman, W.T., Connor, B.F., and Maloney, T.J., 1999, New reporting procedures based on long-term method-detection levels and some considerations for interpretations of water-quality data provided by the U.S. Geological Survey National Water Quality Laboratory: U.S. Geological Survey Open-File Report 99-193, 19 p.

Clark, I.D., and Fritz, P., 1997, Environmental isotopes in hydrogeology: Boca Raton, Florida, CRC Press LLC, 328 p.

Connor, B.F., Rose, D.L., Noriega, M.C., Murtagh, L.K., and Abney, S.R., 1998, Methods of analysis by the U.S. Geological Survey National Water Quality LaboratoryDetermination of 86 volatile organic compounds in water by gas chromatography/mass spectrometry, including detections less than reporting limits: U.S. Geological Survey Open-File Report 97-829, 78 p.

Coplen, T.B., 1994, Reporting of stable hydrogen, carbon, and oxygen isotopic abundances: Pure and Applied Chemistry, v. 66, p. $273-276$.
Coplen, T.B., Wildman, J.D., and Chen, J., 1991, Improvements in the gaseous hydrogen-water equilibrium technique for hydrogen isotope analysis: Analytical Chemistry, v. 63, p. 910-912.

Coplen, T.B., Hopple, J.A., Böhlke, J.K., Peiser, H.S., Rieder, S.E., Krouse, H.R., Rosman, K.J.R., Ding, T., Vocke, R.D., Jr., Revesz, K.M., Lamberty, A., Taylor, P., and DeBierve, P., 2002, Compilation of minimum and maximum isotope ratios of selected elements in naturally occurring terrestrial materials and reagents: U.S. Geological Survey WaterResources Investigations Report 01-4222, 98 p.

Dawson, B.J., Bennett, G.L., V, and Belitz, Kenneth, 2008, Ground-water quality data in the southern Sacramento Valley, California, 2005-Results from the California GAMA Program: U.S. Geological Survey Data Series 285, $93 \mathrm{p}$.

Densmore, J.N., Fram, M.S., and Belitz, Kenneth, 2009, Ground-water quality data in the Owens and Indian Wells Valleys study unit, 2006: Results from the California GAMA program: U.S. Geological Survey Data Series 427, $86 \mathrm{p}$.

Eaton, G.F., Hudson, G.B., and Moran, J.E., 2004, Tritiumhelium-3 age-dating of groundwater in the Livermore Valley of California: American Chemical Society ACS Symposium Series, v. 868, p. 235-245.

Epstein, Samuel, and Mayeda, T.K., 1953, Variation of O-18 content of water from natural sources: Geochimica et Cosmochimica Acta, v. 4, p. 213-224.

Faires, L.M., 1993, Methods of analysis by the U.S. Geological Survey National Water Quality Laboratorydetermination of metals in water by inductively coupled plasma-mass spectrometry: U.S. Geological Survey OpenFile Report 92-634, 28 p.

Faure, Gunter, and Mensing, T.M., 2005, Isotopes-Principles and Applications (3d ed.): Hoboken, New Jersey, John Wiley \& Sons, Inc., 897 p.

Ferrari, M.J., Fram, M.S., and Belitz, Kenneth, 2008, Groundwater quality in the Central Sierra study unit, California, 2006-Results from the California GAMA program: U.S. Geological Survey Data Series 335, 60 p.

Firestone, R.B., Shirley, V.S., Baglin, C.M., Chu, S.Y.F., and Zipkin, J., 1996, Table of isotopes (8th ed.): New York, John Wiley \& Sons, 3168 p., accessed on July 16, 2009, at http:// ie.lbl.gov/toipdf/toi20.pdf

Fishman, M.J., 1993, Methods of analysis by the U.S. Geological Survey National Water Quality Laboratorydetermination of inorganic and organic constituents in water and fluvial sediments: U.S. Geological Survey Open-File Report 93-125, 217 p. 
Fishman, M.J., and Friedman, L.C., 1989, Methods for determination of inorganic substances in water and fluvial sediments: U.S. Geological Survey Techniques of WaterResources Investigations, book 5, chap. A1, 545 p.

Fram, M.S., and Belitz, Kenneth, 2007, Groundwater quality data in the Southern Sierra Study Unit, 2006-Results from the California GAMA Program: U.S. Geological Survey Data Series 258, 78 p.

Fram, M.S., Munday, C.M., and Belitz, Kenneth, 2009, Ground-water quality data for the Tahoe-Martis study unit, 2007-Results from the California GAMA Program: U.S. Geological Survey Data Series 432, 80 p.

Furlong, E.T., Werner, S.L., Anderson, B.D., and Cahill, J.D., 2008, Determination of human-health pharmaceuticals in filtered water by chemically modified styrenedivinylbenzene resin-based sold-phase extraction and highperformance liquid chromatography/mass spectrometry: U.S. Geological Survey Techniques and Methods, book 5, sec. B., chap. B5, 56 p.

Furlong, E.T., Anderson, B.D., Werner, S.L., Soliven, P.P., Coffey, L.J., and Burkhardt, M.R., 2001, Determination of pesticides in water by graphitized carbon-based solid-phase extraction and high-performance liquid chromatography/ mass spectrometry: U.S. Geological Survey WaterResources Investigations Report 01-4134, 73 p.

Garbarino, J.R., 1999, Methods of analysis by the U.S. Geological Survey National Water Quality LaboratoryDetermination of dissolved arsenic, boron, lithium, selenium, strontium, thalium, and vanadium using inductively coupled plasma-mass spectrometry: U.S. Geological Survey Open-File Report 99-093, 31 p.

Garbarino, J.R., and Damrau, D.L., 2001, Methods of analysis by the U.S. Geological Survey National Water Quality Laboratory-Determination of organic plus inorganic mercury in filtered and unfiltered natural water with cold vapor-atomic fluorescence spectrometry: U.S. Geological Survey Water-Resources Investigations Report 01-4132, $16 \mathrm{p}$.

Garbarino, J.R., Kanagy, J.R., and Cree, M.E., 2006, Determination of elements in natural-water, biota, sediment, and soil samples using collision/reaction cell inductively coupled plasma-mass spectrometry: U.S. Geological Survey Techniques and Methods, book 5, chap. B1, 88 p.

Gilliom, R.J., Barbash, J.E., Crawford, C.G., Hamilton, P.A., Martin, J.D., Nakagaki, N., Nowell, L.H., Scott, J.C., Stackelberg, P.E., Thelin, G.P., and Wolock, D.M., 2006, The quality of our nation's waters-Pesticides in the nation's streams and groundwater, 1992-2001: U.S. Geological Survey Circular 1291, 172 p.
Goldrath, D.A., Wright, M.T., and Belitz, Kenneth, 2009, Ground-water quality data in the Coachella Valley study unit, 2007-Results from the California GAMA Program: U.S. Geological Survey Data Series 373, 70 p.

Goldrath, D.A., Wright, M.T., and Belitz, Kenneth, 2010, Groundwater-quality data in the Colorado River study unit, 2007: Results from the California GAMA program: U.S. Geological Survey Data Series 474, 66 p.

Gran, G., 1952, Determination of the equivalence point in potentiometric titration. Part II: Analyst, v. 77, p. 661.

Grob, R.L, ed., 1995, Modern practice of gas chromatography (3d ed.): New York, John Wiley \& Sons, 888 p.

Hahn, G.J., and Meeker, W.Q., 1991, Statistical intervals-a guide for practitioners: New York, John Wiley \& Sons, $392 \mathrm{p}$.

Hamlin, S.N., 1985, Ground-water quality in the Santa Rita, Buellton, and Los Olivos hydrologic subareas of the Santa Ynez River basin, Santa Barbara County, California: U.S. Geological Survey Water-Resources Investigations Report 84-4131, $75 \mathrm{p}$.

Hoaglin, D.C., 1983, Letter values-A set of selected order statistics, in Hoaglin, D.C., Mosteller, F., and Tukey, J.W., eds., Understanding Robust and Exploratory Data Analysis: New York, John Wiley \& Sons, p. 33-54.

Hutson, S.S., Barber, N.L., Kenny, J.F., Linsey, K.S., Lumia, D.S., and Maupin, M.A., 2004, Estimated use of water in the United States in 2000: U.S. Geological Survey Circular $1268,46 \mathrm{p}$.

Karlen, I., Olsson, I.U.,Kallburg, P., and Kilici, S., 1964. Absolute determination of the activity of two ${ }^{14} \mathrm{C}$ dating standards: ArkivGeofysik, vol. 4, p. 465-471.

Kent, R. H., and Belitz, Kenneth, 2009, Ground-water quality data in the Upper Santa Ana Watershed Study Unit, November 2006 to March 2007: Results from the California GAMA Program: U.S. Geological Survey Data Series 404, $116 \mathrm{p}$.

Kolpin, D.W., Furlong, E.T., Meyer, M.T., Thurman, E.M., Zaugg, S.D., Barber, L.B., and Buxton, H.T., 2002, Pharmaceuticals, hormones and other organic wastewater contaminants in U.S. streams, 1999-2000: Environmental Science \& Technology, v. 36, no. 6, p. 1202-1211.

Koterba, M.T., Wilde, F.D., and Lapham, W.W., 1995, Groundwater data-collection protocols and procedures for the National Water-Quality Assessment ProgramCollection and documentation of water-quality samples and related data: U.S. Geological Survey Open-File Report 95-399, $113 \mathrm{p}$. 
Kreiger, H.L., and Whittaker, E.L., 1980, Prescribed procedures for measurement of radioactivity in drinking water: U.S. Environmental Protection Agency EPA-600-480-032, 142 p. (Also available as PB80-224744 at http:// www.ntis.gov)

Kulongoski, J.T., and Belitz, Kenneth, 2004, Groundwater ambient monitoring and assessment program: U.S. Geological Survey Fact Sheet 2004-3088, 2 p.

Kulongoski, J.T., and Belitz, Kenneth, 2007, Groundwater quality data in the Monterey Bay and Salinas Valley Basins, California, 2005-Results from the California GAMA Program: U.S. Geological Survey Data Series 258, 84 p.

Kulongoski, J.T., Belitz, Kenneth, and Dawson, B.J., 2006, Ground-water quality data in the North San Francisco Bay Hydrologic provinces, California, 2004: Results from the California Ground-Water Ambient Monitoring and Assessment (GAMA) Program: U.S. Geological Survey Data Series 167, 100 p.

Land, M.T., and Belitz, Kenneth, 2008, Groundwater quality data in the San Fernando-San Gabriel study unit, 2005-Results from the California GAMA Program: U.S. Geological Survey Data Series 356, 84 p.

Landon, M.K., and Belitz, Kenneth, 2008, Groundwater quality data in the Central Eastside San Joaquin Basin 2006:Results from the California GAMA Program: U.S. Geological Survey Data Series 325, 88 p.

Landon, M.K., Belitz, Kenneth, Jurgens, B.C., Kulongoski, J.T., and Johnson, T.D., 2010, Status and understanding of groundwater quality in the Central-Eastside San Joaquin Basin, 2006: California GAMA Priority Basin project: U.S. Geological Survey Scientific Investigations Report 20095266, $97 \mathrm{p}$.

Lane, S.L., Flanagan, Sarah, and Wilde, F.D., 2003, Selection of equipment for water sampling (ver. 2.0): U.S. Geological Survey Techniques of Water-Resources Investigations, book 9, chap. A2, accessed September 17, 2009, at http:// pubs.water.usgs.gov/twri9A2/

Lewis, M.E., 2006, Dissolved oxygen (ver. 2.1): U.S. Geological Survey Techniques of Water-Resources Investigations, book 9, chap. A6.2, accessed August 18, 2009, at http://pubs.water.usgs.gov/twri9A6.2/

Lindley, C.E., Stewart, J.T., and Sandstrom, M.W., 1996, Determination of low concentrations of acetochlor in water by automated solid-phase extraction and gas chromatography with mass selective detection: Journal of AOAC International, v. 79, no. 4, p. 962-966.
Madsen, J.E., Sandstrom, M.W., and Zaugg, S.D., 2003, Methods of analysis by the U.S. Geological Survey National Water Quality Laboratory-A method supplement for the determination of fipronil and degradates in water by gas chromatography/mass spectrometry: U.S. Geological Survey Open-File Report 02-462, 11 p.

Maloney, T.J., ed., 2005, Quality management system, U.S. Geological Survey National Water Quality Laboratory: U.S. Geological Survey Open-File Report 2005-1263, accessed September 8, 2009, at http://pubs.usgs.gov/of/2005/1263/.

Mathany, T.M., and Belitz, Kenneth, 2009, Ground-water quality data in the Mojave Study Unit, 2008: Results from the California GAMA Program: U.S. Geological Survey Data Series 440, $80 \mathrm{p}$.

Mathany, T.M., Land, Michael, and Belitz, Kenneth, 2008, Groundwater quality data in the Coastal Los Angeles Basin Study Unit, 2006: Results from the California GAMA Program: U.S. Geological Survey Data Series 387, 98 p.

Mathany, T.M., Kulongski, J.T., Ray, M.C., and Belitz, Kenneth, 2009, Groundwater-quality data in the South Coast Interior Basins study unit, 2008: Results from the California GAMA program: U.S. Geological Survey Data Series $463,82 \mathrm{p}$.

McCleskey, R.B., Nordstrom, D.K., and Ball, J.W., 2003, Metal interferences and their removal prior to the determination of $\mathrm{As}(\mathrm{T})$ and $\mathrm{As}(\mathrm{III})$ in acid mine waters by hydride generation atomic absorption spectrometry: U.S. Geological Survey Water-Resources Investigations Report 03-4117, $14 \mathrm{p}$.

McCurdy, D.E., Garbarino, J.R., and Mullin, A.H., 2008, Interpreting and reporting radiological water-quality data: U.S. Geological Survey Techniques and Methods, book 5, chap. B6, 33 p.

McLain, B., 1993, Methods of analysis by the U.S. Geological Survey National Water Quality Laboratory-Determination of chromium in water by graphite furnace atomic absorption spectrophotometry: U.S. Geological Survey Open-File Report 93-449, $16 \mathrm{p}$.

Montrella, Joseph, and Belitz, Kenneth, 2009, Groundwater quality data in the Santa Clara River Valley study unit, 2007: Results from the California GAMA Program: U.S. Geological Survey Data Series 408, 84 p.

Moran, J.E., Hudson, G.B., Eaton, G.F., and Leif, R., 2002, A contamination vulnerability assessment for the Livermore-Amador and Niles Cone Groundwater Basins: Lawrence Livermore National Laboratory internal report UCRL-AR-148831, 25 p. 
Mueller, D.K., and Titus, C.J., 2005, Quality of nutrient data from streams and ground water sampled during water years 1992-2001: U.S. Geological Survey Scientific Investigations Report 2005-5106, 27 p.

Okamoto, H.S., Steeber, W.R., Remoy, R., Hill P., and Perera, S.K., eds., 2002, Determination of 1,2,3-trichloropropane in drinking water by purge and trap gas chromatography/ mass spectrometry: California Department of Health Services, Division of Drinking Water and Environmental Management, Sanitation and Radiation Laboratories Branch, accessed September 4, 2009 at http://www.cdph. ca.gov/certlic/drinkingwater/Documents/Drinkingwaterlabs/ TCPbyPT-GCMS.pdf

Olsen, L.D., Fram, M.S., and Belitz, Kenneth, 2010, Review of trace-element field-blank data collected for the California Groundwater Ambient Monitoring and Assessment (GAMA) Program, May 2004-January 2008: U.S. Geological Survey Scientific Investigations Report 2009$5220,47 \mathrm{p}$.

Olsson, I.U., 1970, The use of oxalic acid as a standard, in Olsson, I.U., ed., Radiocarbon Variations and Absolute Chronology, Nobel Symposium, $12^{\text {th }}$, Proceedings: New York, John Wiley \& Sons, p. 17.

Patton, C.J., and Kryskalla, J.R., 2003, Methods of analysis by the U.S. Geological Survey National Water Quality Laboratory-Evaluation of alkaline persulfate digestion as an alternative to Kjeldahl digestion for determination of total and dissolved nitrogen and phosphorous in water: U.S. Geological Survey Water-Resources Investigations Report 03-4174, $33 \mathrm{p}$.

Patton, C.J., and Truitt, E.P., 2000, Methods of analysis by the U.S. Geological Survey National Water Quality LaboratoryDetermination of ammonium plus organic nitrogen by a Kjeldahl digestion method and an automated photometric finish that includes digest cleanup by gas diffusion: U.S. Geological Survey Open-File Report 00-170, 31 p.

Pirkey, K.D., and Glodt, S.R., 1998, Quality control at the U.S. Geological Survey National Water Quality Laboratory: U.S. Geological Survey Fact-Sheet 026-98, 4 p., accessed February 12, 2010 at http://pubs.er.usgs.gov/usgspubs/fs/ $\underline{\mathrm{fs} 02698}$

Plomley, J.B., Koester, C.J., and March, R.E., 1994, Determination of NDMA in complex environmental matrices by quadrupole ion storage tandem mass spectrometry enhanced by unidirectional ion ejection: Analytical Chemistry, v. 66, no. 24, p. 4437-4443.

Price, C.V., Nakagaki, N., Hitt, K.J., and Clawges, R.M., 2003, Mining GIRAS-improving on a national treasure of land use data, in Conference of the ESRI International Users, $23^{\text {rd }}$, Redlands, Calif., July 7-11, 2003, Proceedings: Redlands, Calif., ESRI, 11 p.
Radtke, D.B., Davis, J.V., and Wilde, F.D., 2005, Specific electrical conductance (ver. 1.2): U.S. Geological Survey Techniques of Water-Resources Investigations, book 9, chap. A6.3, accessed August 17, 2009 at http://pubs.water. usgs.gov/twri9A6.3/

Ray, M.C., Kulongoski, J.T., and Belitz, Kenneth, 2009, Groundwater quality data in the San Francisco Bay study unit, 2007: Results from the California GAMA program: U.S. Geological Survey Data Series 396, 92 p.

Révész, K., and Casciotti, K., 2007, Determination of the $\delta\left({ }^{15} \mathrm{~N} /{ }^{14} \mathrm{~N}\right)$ and $\delta\left({ }^{18} \mathrm{O} /{ }^{16} \mathrm{O}\right)$ of nitrate in water: RSIL Lab Code 2900, chap. C17 in Révész, Kinga, and Coplen, T.B., eds., Methods of the Reston Stable Isotope Laboratory: U.S. Geological Survey Techniques and Methods, book 10, sec. C, chap. 17, 24 p.

Sandstrom, M.W., Stroppel, M.E., Foreman, W.T., and Schroeder, M.P., 2001, Methods of analysis by the U.S. Geological Survey National Water Quality LaboratoryDetermination of moderate-use pesticides and selected degradates in water by C- 18 solid-phase extraction and gas chromatography/mass spectrometry: U.S. Geological Survey Water-Resources Investigations Report 01-4098, $70 \mathrm{p}$.

Saucedo, G.J., Bedford, D.R., Raines, G.L., Miller, R.J., and Wentworth, C.M., 2000, GIS data for the geologic map of California (version 2.0): California Department of Conservation, Division of Mines and Geology, Sacramento, Calif., CD 2000-07.

Schmitt, S.J., Fram, M.S., Milby Dawson, B.J., Belitz, Kenneth, 2008, Ground-water quality data in the Middle Sacramento Valley study unit, 2006-Results from the California GAMA program: U.S. Geological Survey Data Series 385, $100 \mathrm{p}$.

Scott, J.C., 1990, Computerized stratified random site selection approaches for design of a ground-water quality sampling network: U.S. Geological Survey Water-Resources Investigations Report 90-4101, 109 p.

Shelton, J.L., Fram, M.S., and Belitz, Kenneth, 2009, Groundwater-quality data for the Madera-Chowchilla study unit, 2008: Results from the California GAMA program: U.S. Geological Survey Data Series 455, 80 p.

Shelton, J.L., Burow, K.R., Belitz, Kenneth, Dubrovsky, N.M., Land, M.T., and Gronberg, J.M., 2001, Low-level volatile organic compounds in active public supply wells as groundwater tracers in the Los Angeles physiographic basin, California, 2000: U.S. Geological Survey Water-Resources Investigations Report 01-4188, 29 p. 
Shelton, J.L., Pimentel, I., Fram, M.S., Belitz, Kenneth, 2008, Ground-water quality in the Kern County Subbasin Study Unit, 2006-Results from the California GAMA Program: U.S. Geological Survey Data Series 337, 75 p.

Soddy, F, 1913, Radioactivity: Annual Reports on the Progress of Chemistry, v. 10, p. 262-288.

State Water Resources Control Board, 2003, Report to the Governor and Legislature, A comprehensive groundwater quality monitoring program for California: Assembly Bill 599 March 2003, 121 p., accessed February 12, 2010, at http://www.waterboards.ca.gov/gama/docs/final ab 599 rpt to legis 731 03.pdf

Stookey, L.L., 1970, FerroZine-A new spectrophotometric reagent for iron: Analytical Chemistry, v. 42, p. 779-781.

Stuiver, M., 1980,Workshop on ${ }^{14} \mathrm{C}$ data reporting: Radiocarbon, v. 22, p. 964-966.

Stuiver, M., and Polach, H.A., 1977, Discussion-Reporting of ${ }^{14} \mathrm{C}$ data: Radiocarbon, v. 19 , p. 355-363.

Thatcher, L.L., Janzer, V.J., and Edwards, K.W., 1977, Methods for the determination of radioactive substances in water: U.S. Geological Survey Techniques of WaterResources Investigations, book 5, chap. A5, 95 p.

Timme, P.J., 1995, National Water Quality Laboratory 1995 services catalog: U.S. Geological Survey Open-File Report 95-352, $120 \mathrm{p}$.

To, T.B., Nordstrom, D.K., Cunningham, K.M., Ball, J.W., and McCleskey, R.B., 1998, New method for the direct determination of dissolved $\mathrm{Fe}$ (III) concentration in acid mine waters: Environmental Science and Technology, v. 33, p. $807-813$.

U.S. Environmental Protection Agency, 1989, Semivolatile organic compounds by isotope dilution GSMS (July 1989): Washington, D.C., U.S. Environmental Protection Agency, $68 \mathrm{p}$.

U.S. Environmental Protection Agency, 2002, Guidelines for establishing procedures for the analysis of pollutants: U.S. Code of Federal Regulations, Title 40, 136 p.

U.S. Environmental Protection Agency, 2005, Method 331.0 Determination of perchlorate in drinking water by liquid chromatography electrospray ionization mass spectrometry (Revision 1.0, January 2005): Office of Groundwater and Drinking Water, EPA Document \# 815-R-05-007, 34 p., accessed September 3, 2009, at http://www.epa.gov/ safewater/methods/pdfs/methods/met331 0.pdf

U.S. Environmental Protection Agency, 2008a, Drinking water contaminants, accessed September 2, 2009, at http://www. epa.gov/safewater/contaminants/index.html
U.S. Environmental Protection Agency, 2008b, Drinking water health advisories-2006. Drinking water standards and health advisory tables, accessed September 2, 2009, at http://www.epa.gov/waterscience/criteria/drinking

U.S. Geological Survey, 2008, Branch of Quality Systems, Inorganic blind sample project, accessed September 10, 2009, at http://bqs.usgs.gov/bsp/ (As of May 18, 2010, accessible at http://bqs.usgs.gov/ibsp/index.shtml)

U.S. Geological Survey, [variously dated], National field manual for the collection of water-quality data: U.S. Geological Survey Techniques of Water-Resources Investigations, book 9, chap. A1-A9, accessed September 7, 2009, at http://water.usgs.gov/owq/FieldManual/

Valentine, D.W., Densmore, J.N., Galloway, D.L., and Amelung, F., 2001, Use of InSAR to identify land-surface displacements caused by aquifer-system compaction in the Paso Robles Area, San Luis Obispo County, California, March to August 1997: U.S. Geological Survey Open-File Report 00-447, 1 p.

Volgelmann, J.E., Howard, S.M.,Yang, L., Larson, C.R., Wylie, B.K., and Van Driel, N., 2001, Completion of the 1990s National Land Cover Data Set for the conterminous Unites States from Landsat Thematic Mapper data and ancillary data sources: Photogrammetric Engineering \& Remote Sensing, v. 17, p. 150-612.

Water Education Foundation, 2006, Where does my water come from?: Sacramento, California, Water Education Foundation, accessed September 10, 2009, at http://www. water-ed.org/watersources/default.asp

Weiss, R.F., 1968, Piggyback sampler for dissolved gas studies on sealed water samples: Deep Sea Research, v. 15, p. $721-735$.

Wilde, F.D., ed., 2004, Cleaning of equipment for water sampling (ver. 2.0): U.S. Geological Survey Techniques of Water-Resources Investigations, book 9, chap. A3, accessed September 7, 2009, at http://pubs.water.usgs.gov/twri9A3/

Wilde, F.D., 2006, Temperature (ver. 2): U.S. Geological Survey Techniques of Water-Resources Investigations, book 9, chap. A6.1, accessed September 7, 2009, at http://pubs. water.usgs.gov/twri9A6.1/

Wilde, F.D., Busenberg, E., and Radtke, D.B., 2006, pH (ver. 1.3): U.S. Geological Survey Techniques of WaterResources Investigations, book 9, chap. A6.4, accessed September 7, 2009, at http://pubs.water.usgs.gov/twri9A6.4/

Wilde, F.D., and Radtke, D.B., 2005, Field measurements (ver. 1.2): U.S. Geological Survey Techniques of WaterResources Investigations, book 9, chap. A6.0, accessed September 7, 2009, at http://pubs.water.usgs.gov/twri9A6.0/ 
Wilde, F.D., Radtke, D.B., Gibs, J., and Iwatsubo, R.T., 1999, Collection of water samples: U.S. Geological Survey Techniques of Water-Resources Investigations, book 9, chap. A4, accessed September 7, 2009, at http://pubs.water. usgs.gov/twri9A4/

Wilde, F.D., Radtke, D.B., Gibs, J., and Iwatsubo, R.T., 2004, Processing of water samples: U.S. Geological Survey Techniques of Water-Resources Investigations, book 9, chap. A5, accessed September 7, 2009, at http://pubs.water. usgs.gov/twri9A5/

Wright, M.T., Belitz, Kenneth, and Burton, C.A., 2005, California GAMA program - Ground-water quality data in the San Diego drainages hydrologic province, California, 2004: U.S. Geological Survey Data Series 129, 91 p.
Yurewicz, M.C., 1981, Incremental field titration of bicarbonate: U.S. Geological Survey Water Resources Division Bulletin, October-December 1981, p. 8-13.

Zaugg, S.D., Sandstrom, M.W., Smith, S.G., and Fehlberg, K.M., 1995, Methods of analysis by the U.S. Geological Survey National Water Quality Laboratory-Determination of pesticides in water by $\mathrm{C}-18$ solid-phase extraction and capillary-column gas chromatography/mass spectrometry: U.S. Geological Survey Open-File Report 95-181, 60 p. 


\section{Tables}


Table 1. Identification, sampling, and construction information for wells and identification and sampling information for surface-water sites sampled for the South Coast Range-Coastal (SCRC) Groundwater Ambient Monitoring and Assessment (GAMA) study, California, May to December 2008.

[GAMA identification number: SCRC-B, Basins study area grid well; SCRC-H, Uplands study area grid well; SCRC-SW, surface-water site; SCRC-U, understanding well. Other abbreviations: ft, foot; LSD, land surface datum; NAVD 88, North American Vertical Datum 1988; na, not available; nv, no value in category]

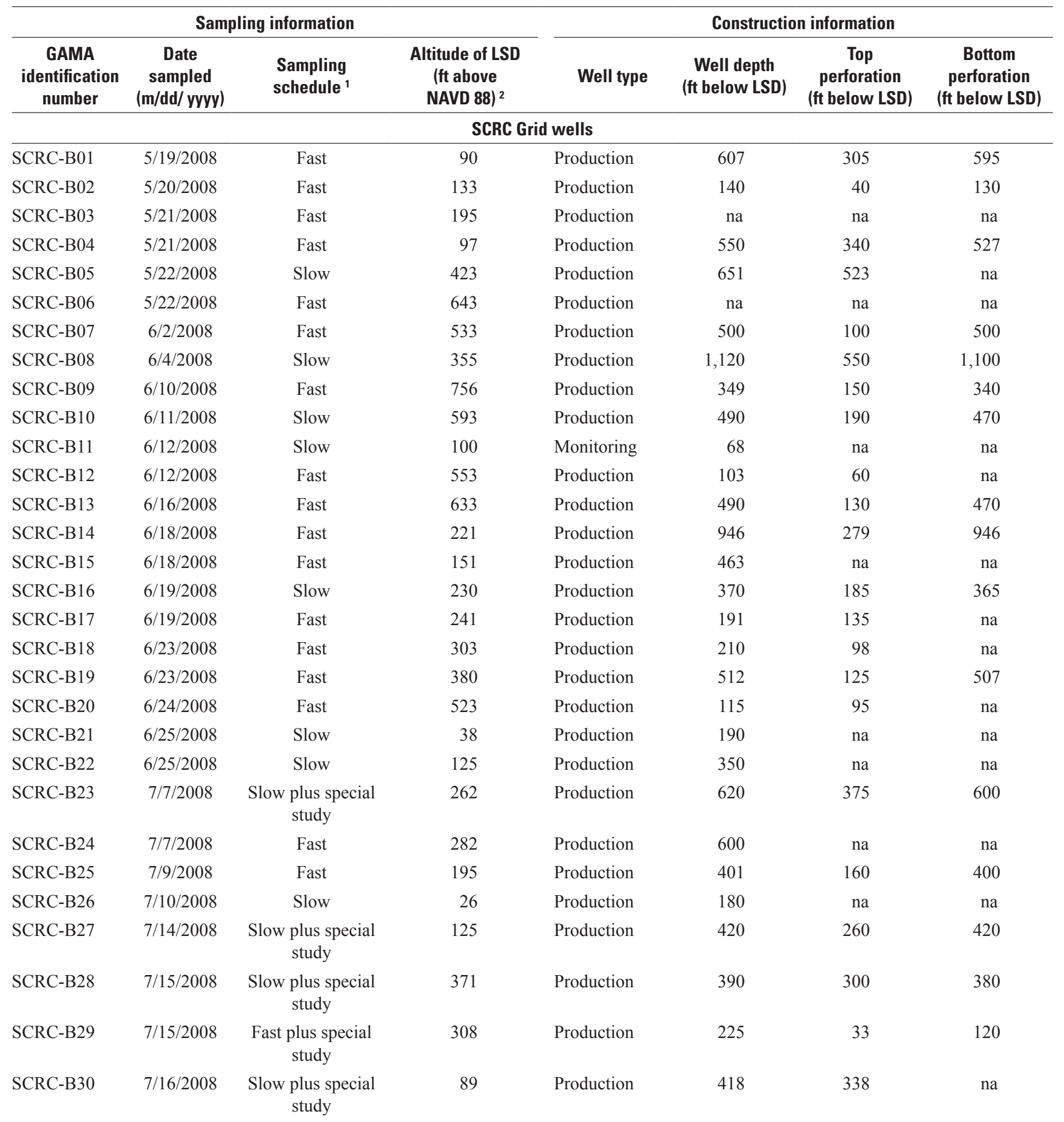


Table 1. Identification, sampling, and construction information for wells and identification and sampling information for surface-water sites sampled for the South Coast Range-Coastal (SCRC) Groundwater Ambient Monitoring and Assessment (GAMA) study, California, May to December 2008.-Continued

[GAMA identification number: SCRC-B, Basins study area grid well; SCRC-H, Uplands study area grid well; SCRC-SW, surface-water site; SCRC-U, understanding well. Other abbreviations: ft, foot; LSD, land surface datum; NAVD 88, North American Vertical Datum 1988; na, not available; nv, no value in category]

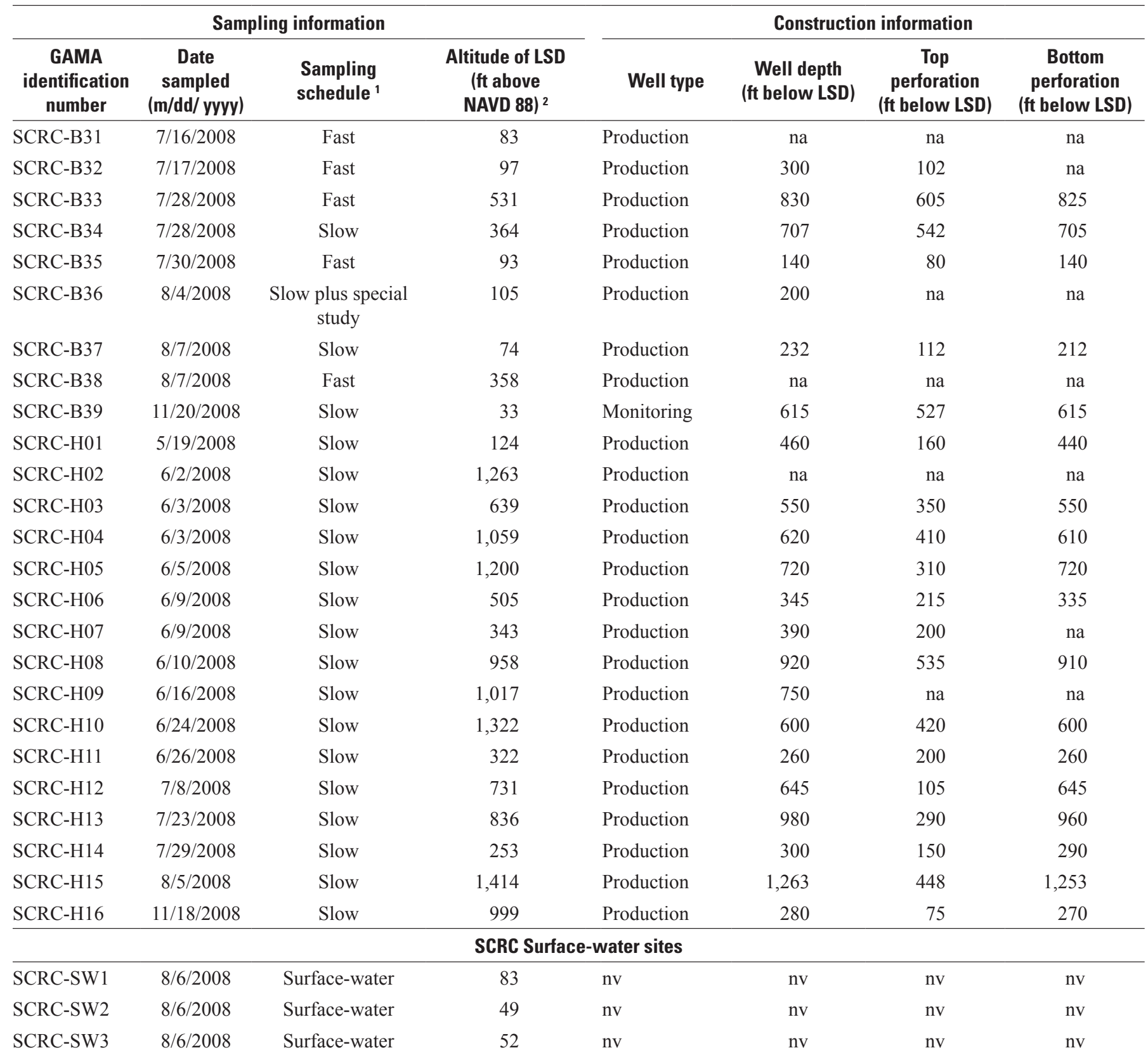


Table 1. Identification, sampling, and construction information for wells and identification and sampling information for surface-water sites sampled for the South Coast Range-Coastal (SCRC) Groundwater Ambient Monitoring and Assessment (GAMA) study, California, May to December 2008.-Continued

[GAMA identification number: SCRC-B, Basins study area grid well; SCRC-H, Uplands study area grid well; SCRC-SW, surface-water site; SCRC-U, understanding well. Other abbreviations: ft, foot; LSD, land surface datum; NAVD 88, North American Vertical Datum 1988; na, not available; nv, no value in category]

\begin{tabular}{|c|c|c|c|c|c|c|c|}
\hline \multicolumn{4}{|c|}{ Sampling information } & \multicolumn{4}{|c|}{ Construction information } \\
\hline $\begin{array}{c}\text { GAMA } \\
\text { identification } \\
\text { number }\end{array}$ & $\begin{array}{c}\text { Date } \\
\text { sampled } \\
\text { (m/dd/ yyyy) }\end{array}$ & $\begin{array}{l}\text { Sampling } \\
\text { schedule }^{1}\end{array}$ & $\begin{array}{c}\text { Altitude of LSD } \\
\text { (ft above } \\
\text { NAVD 88) }{ }^{2}\end{array}$ & Well type & $\begin{array}{c}\text { Well depth } \\
\text { (ft below LSD) }\end{array}$ & $\begin{array}{c}\text { Top } \\
\text { perforation } \\
\text { (ft below LSD) }\end{array}$ & $\begin{array}{c}\text { Bottom } \\
\text { perforation } \\
\text { (ft below LSD) }\end{array}$ \\
\hline \multicolumn{8}{|c|}{ SCRC Understanding wells } \\
\hline SCRC-U01 & $7 / 29 / 2008$ & Fast & 32 & Production & 130 & na & na \\
\hline SCRC-U04 & $7 / 9 / 2008$ & $\begin{array}{l}\text { Fast plus special } \\
\text { study }\end{array}$ & 209 & Production & 125 & 115 & 125 \\
\hline SCRC-U05 & $7 / 24 / 2008$ & Fast & 102 & Monitoring & 55 & 35 & 55 \\
\hline SCRC-U06 & $7 / 24 / 2008$ & $\begin{array}{l}\text { Slow plus special } \\
\text { study }\end{array}$ & 253 & Production & 582 & na & na \\
\hline SCRC-U09 & $8 / 4 / 2008$ & $\begin{array}{l}\text { Slow plus special } \\
\text { study }\end{array}$ & 141 & Production & 186 & na & na \\
\hline SCRC-U10 & $8 / 5 / 2008$ & $\begin{array}{l}\text { Slow plus special } \\
\text { study }\end{array}$ & 143 & Production & na & na & na \\
\hline SCRC-U11 & $7 / 21 / 2008$ & Fast & 203 & Monitoring & 19 & 10 & 19 \\
\hline SCRC-U12 & $7 / 21 / 2008$ & Fast & 452 & Monitoring & 77 & 72 & 77 \\
\hline SCRC-U13 & $7 / 22 / 2008$ & Fast & 174 & Monitoring & 23 & 8 & 23 \\
\hline SCRC-U14 & $7 / 22 / 2008$ & Fast & 183 & Monitoring & 18 & 8 & 18 \\
\hline
\end{tabular}

${ }^{1}$ Sampling schedules are described in table 2.

${ }^{2}$ Land-surface datum (LSD) is a datum plane that is approximately at land surface at each well. The altitude of the LSD is described in feet above the North American Vertical Datum 1988. 


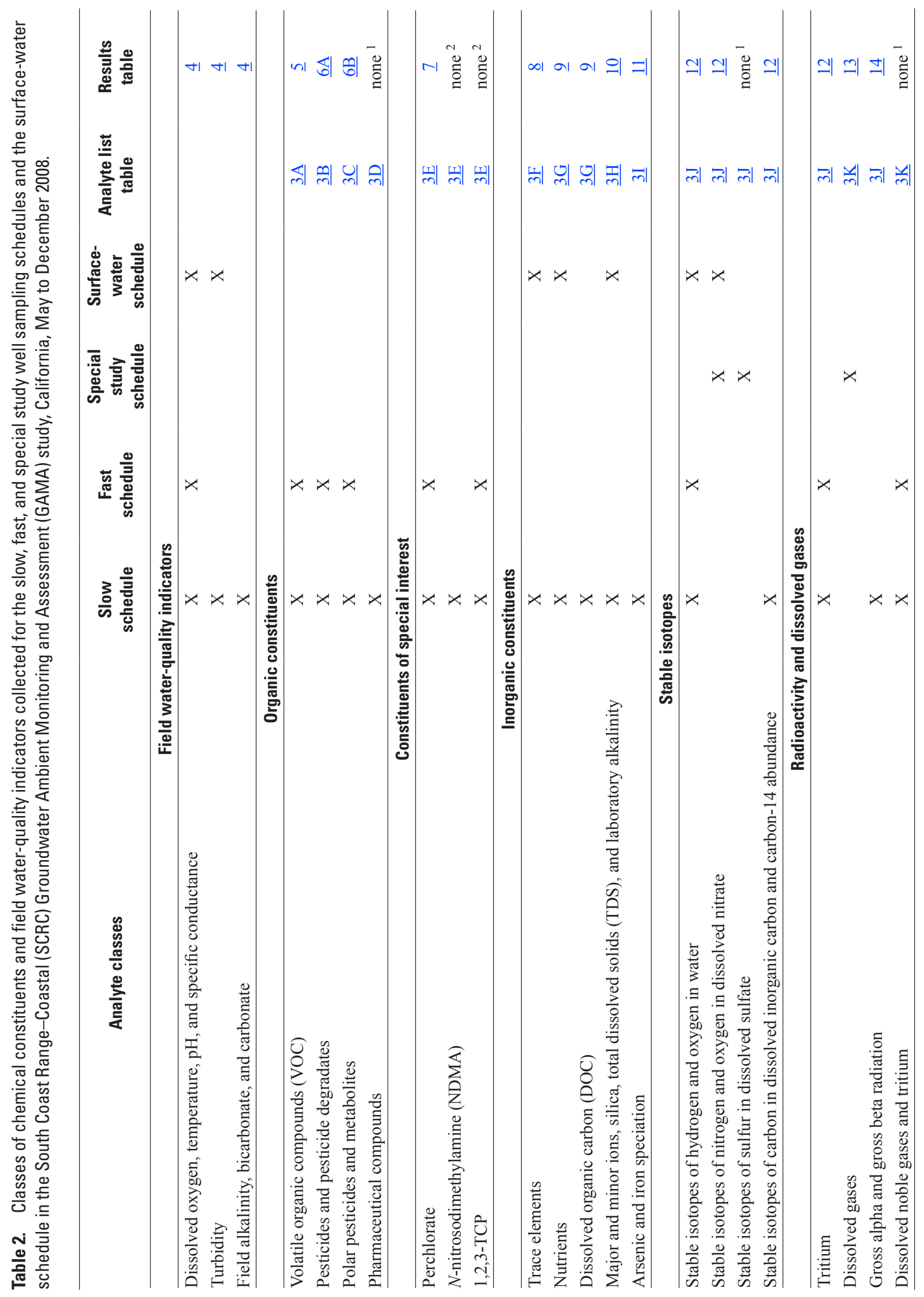




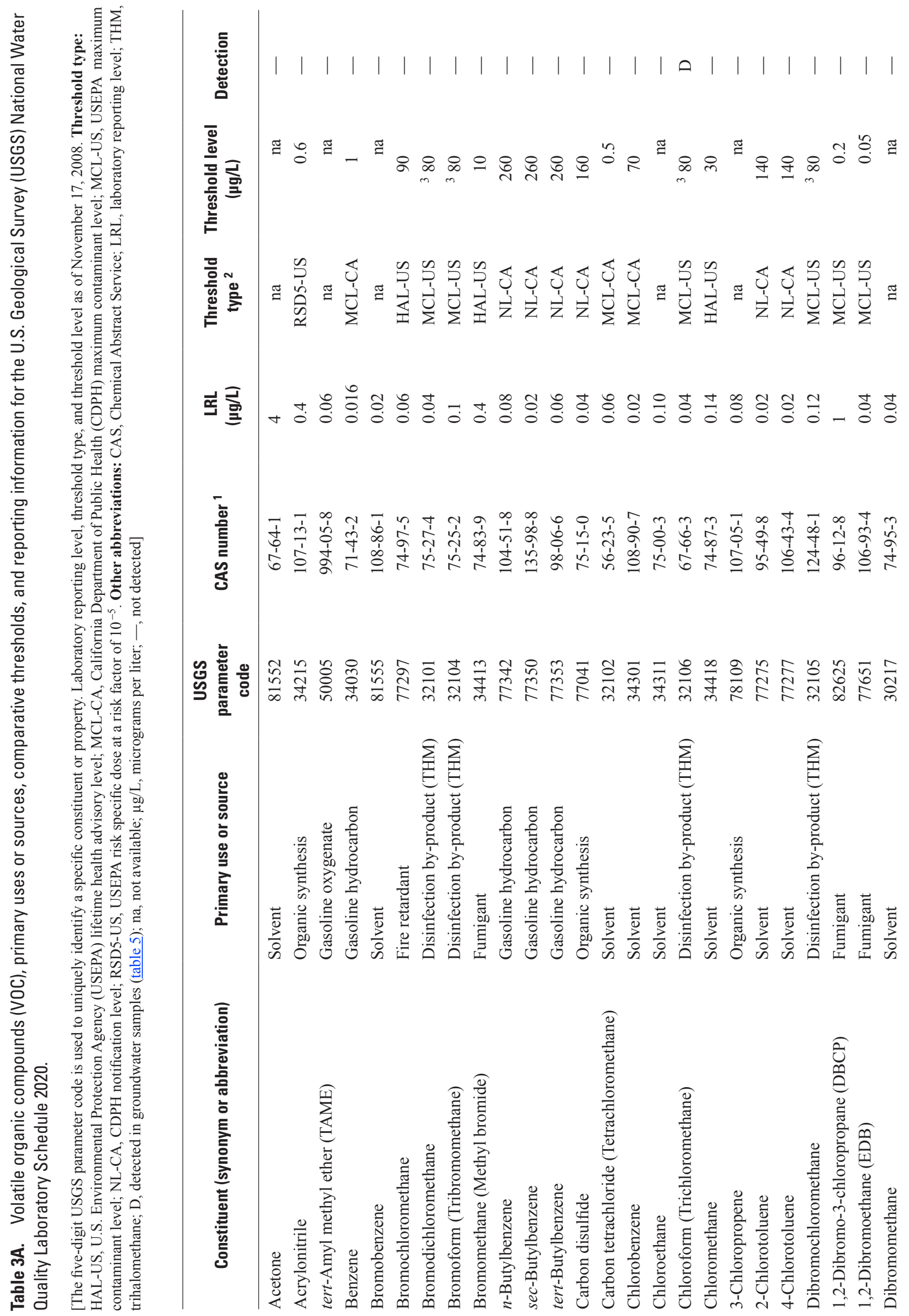



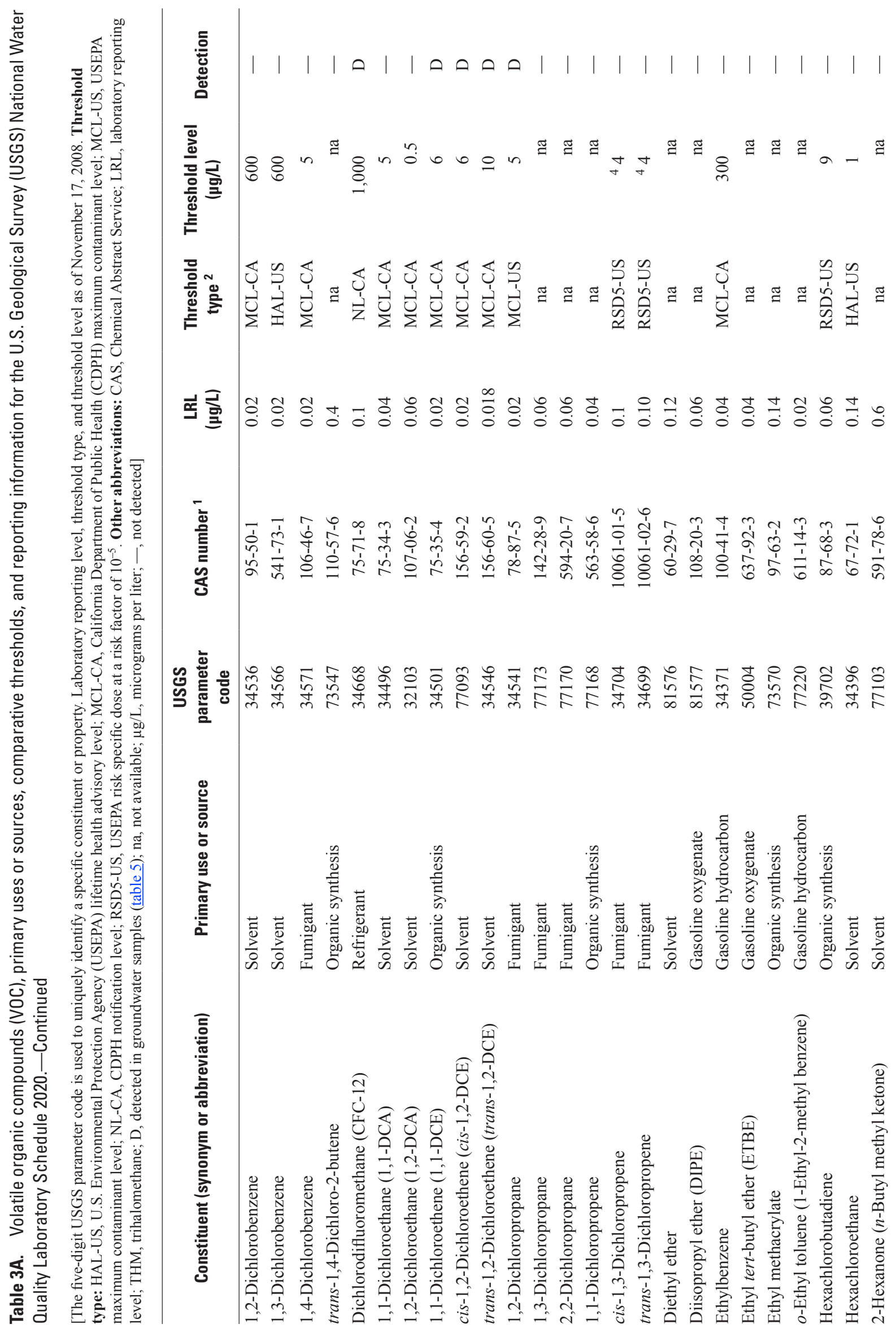


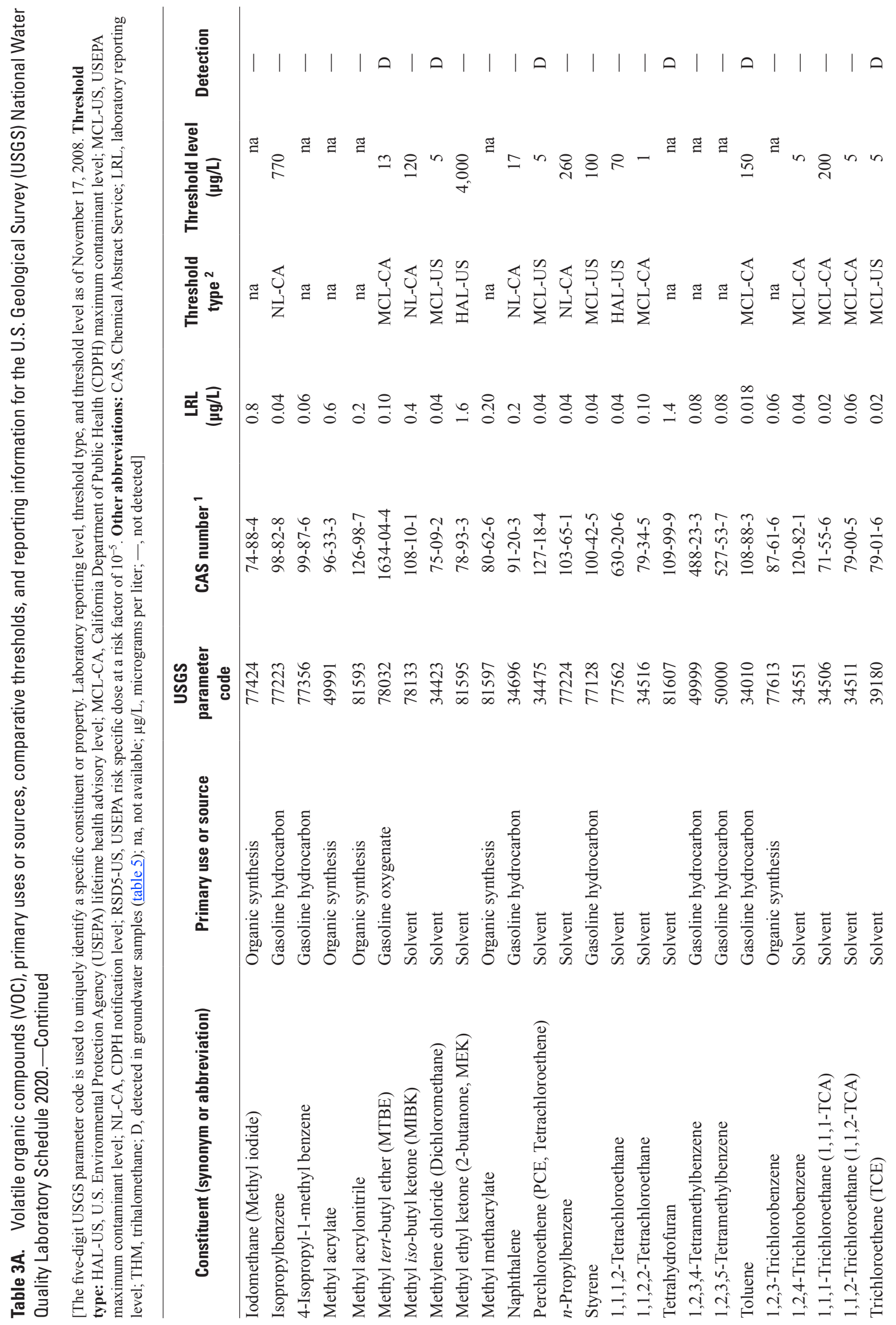




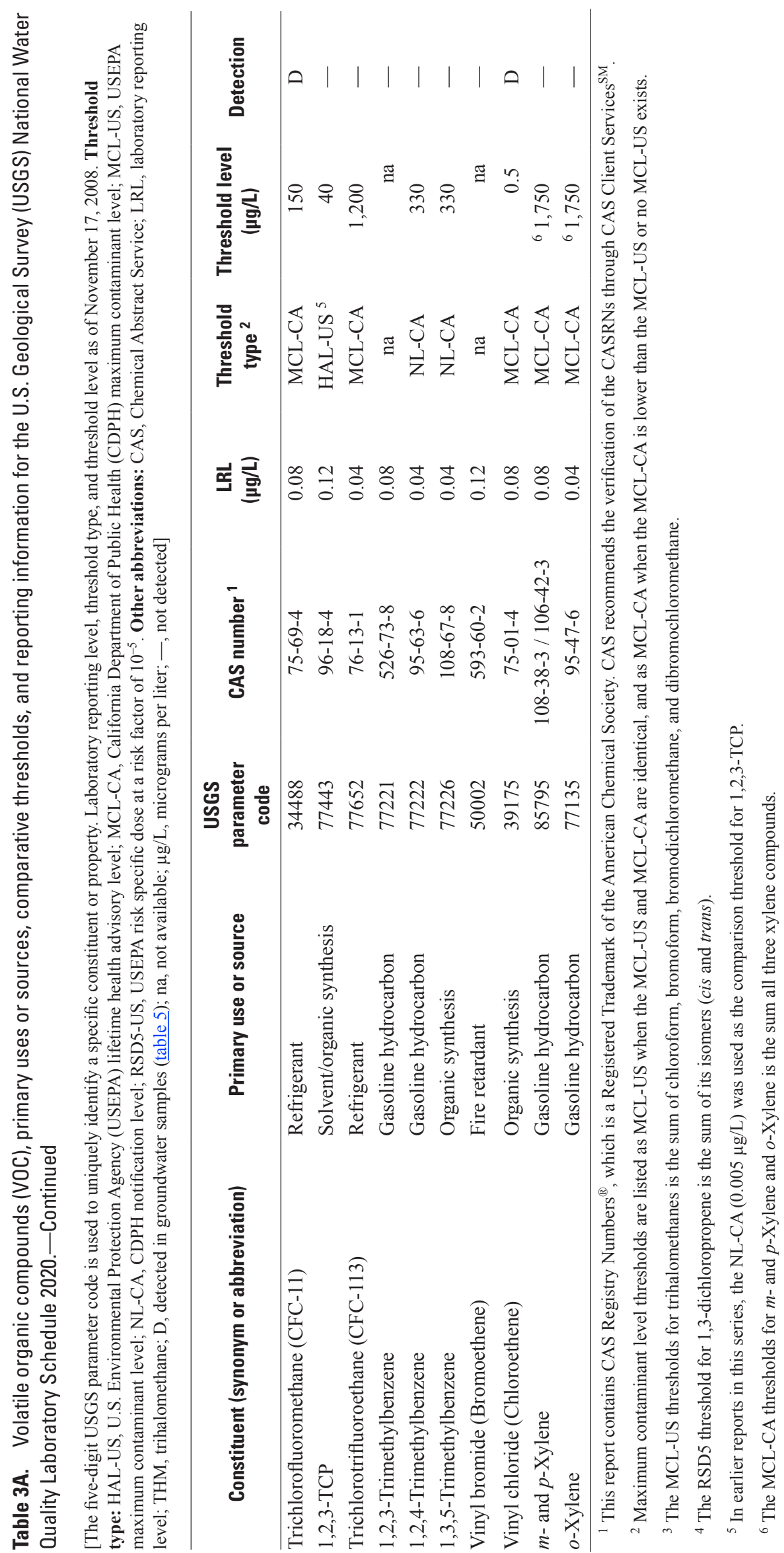


Table 3B. Pesticides and pesticide degradates, primary uses or sources, comparative thresholds, and reporting information for the U.S. Geological Survey (USGS) National Water Quality Laboratory Schedule 2003.

[The five-digit USGS parameter code is used to uniquely identify a specific constituent or property. Laboratory reporting level, threshold type, and threshold level as of November 17, 2008. Threshold type: HAL-US, U.S. Environmental Protection Agency (USEPA) lifetime health advisory level; MCL-CA, California Department of Public Health maximum contaminant level; MCL-US, USEPA maximum contaminant level; RSD5-US, USEPA risk specific dose at a risk factor of $10^{-5}$. Other abbreviations: CAS, Chemical Abstract Service; LRL, laboratory reporting level; D, detected in groundwater samples (table 6A); na, not available; $\mu \mathrm{g} / \mathrm{L}$, micrograms per liter; - , not detected]

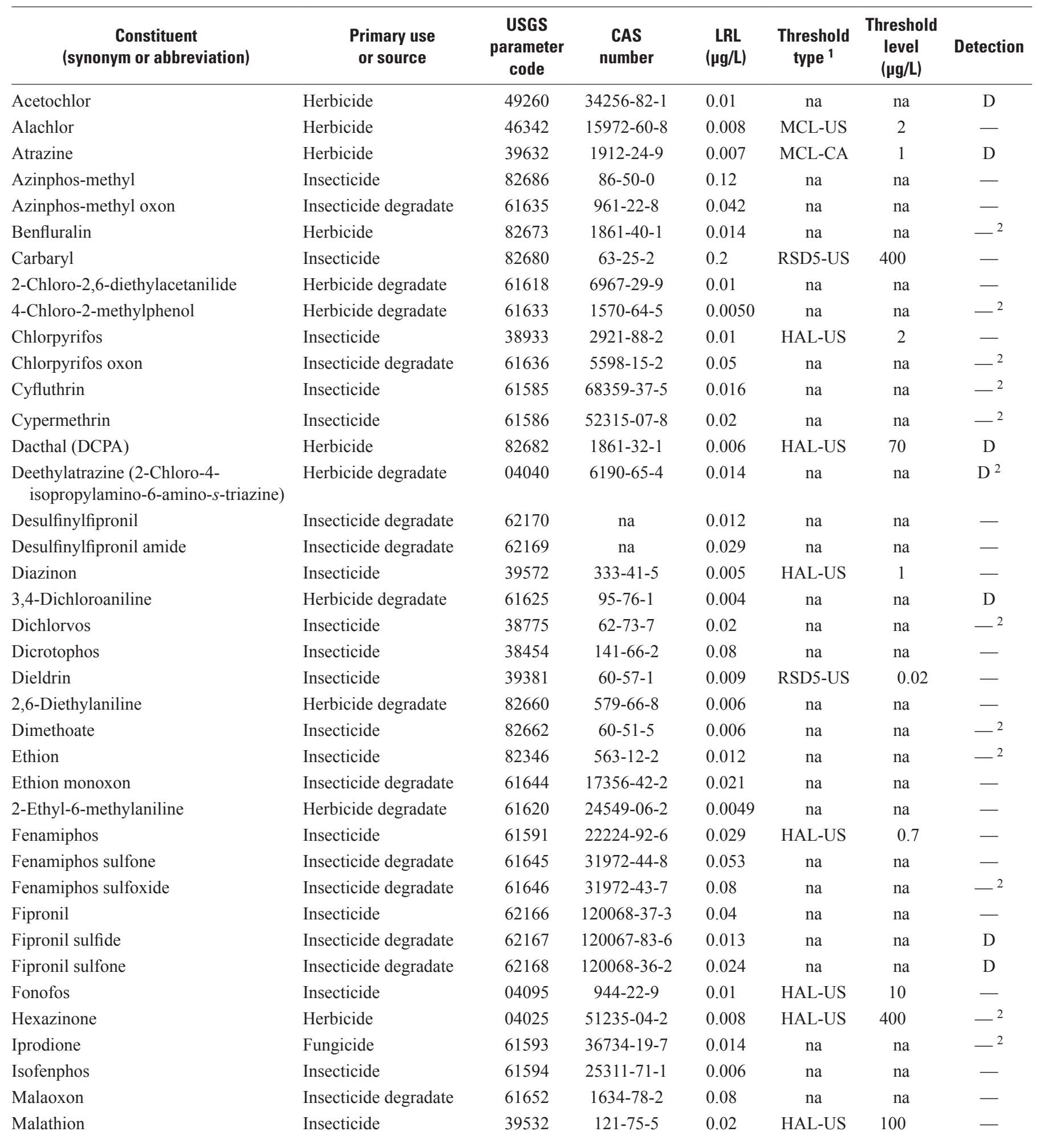


Table 3B. Pesticides and pesticide degradates, primary uses or sources, comparative thresholds, and reporting information for the U.S. Geological Survey (USGS) National Water Quality Laboratory Schedule 2003.-Continued

[The five-digit USGS parameter code is used to uniquely identify a specific constituent or property. Laboratory reporting level, threshold type, and threshold level as of November 17, 2008. Threshold type: HAL-US, U.S. Environmental Protection Agency (USEPA) lifetime health advisory level; MCL-CA, California Department of Public Health maximum contaminant level; MCL-US, USEPA maximum contaminant level; RSD5-US, USEPA risk specific dose at a risk factor of $10^{-5}$. Other abbreviations: CAS, Chemical Abstract Service; LRL, laboratory reporting level; D, detected in groundwater samples (table 6A); na, not available; $\mu \mathrm{g} / \mathrm{L}$, micrograms per liter; - , not detected]

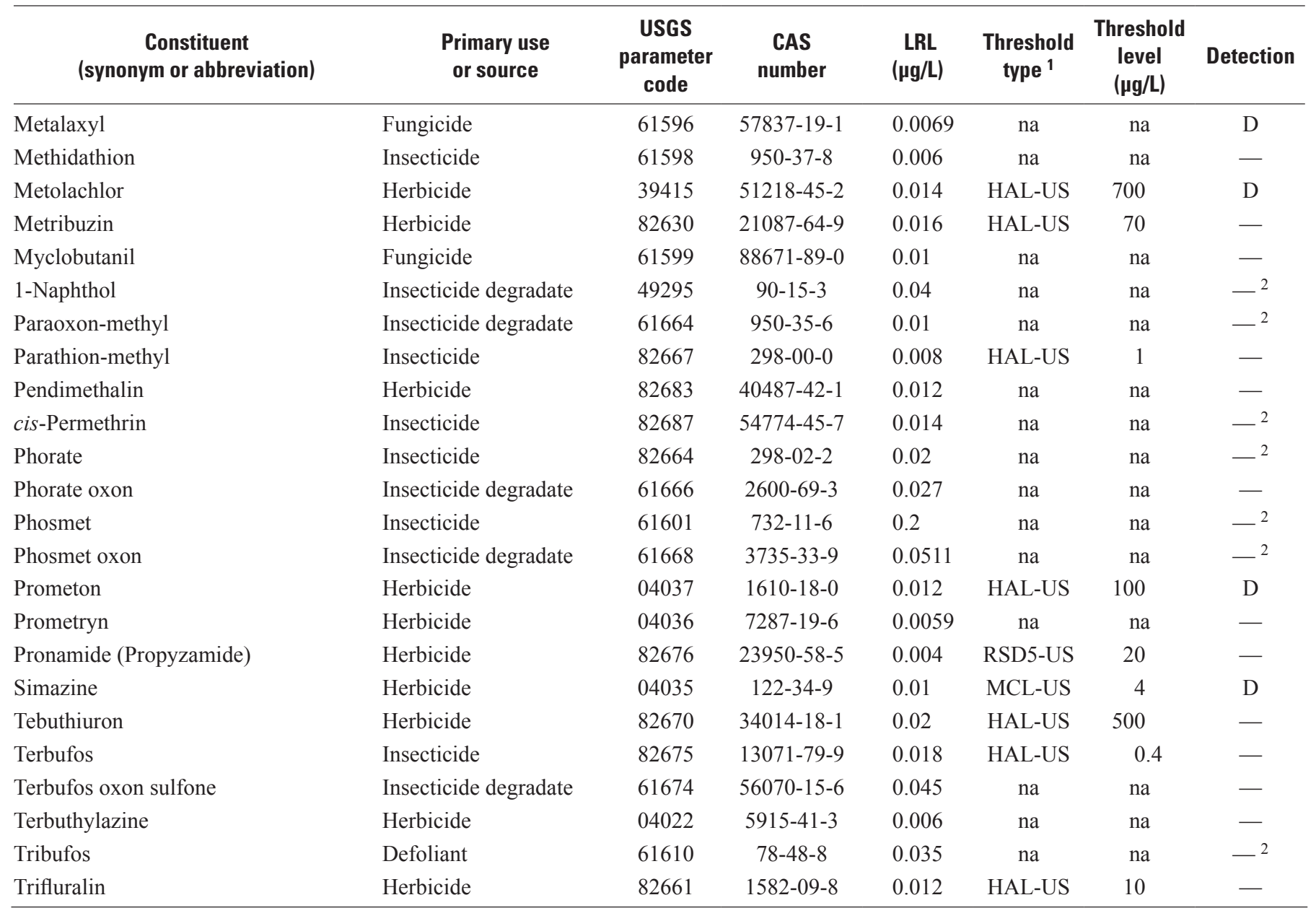

\footnotetext{
${ }^{1}$ Maximum contaminant level thresholds are listed as MCL-US when the MCL-US and MCL-CA are identical, and as MCL-CA when the MCL-CA is lower than the MCL-US or no MCL-US exists.

${ }^{2}$ The median matrix-spike recovery was less than 70 percent. Low recoveries may indicate that the compound might not have been detected in some samples if it was present at very low concentrations.
} 
Table 3C. Polar pesticides and metabolites, primary uses or sources, comparative thresholds, and reporting information for the U.S. Geological Survey (USGS) National Water Quality Laboratory Schedule 2060.

[The five-digit USGS parameter code is used to uniquely identify a specific constituent or property. Laboratory reporting level, interim reporting level, threshold type, and threshold level as of November 17, 2008. Threshold type: HAL-US, U.S. Environmental Protection Agency (USEPA) lifetime health advisory; MCL-CA, California Department of Public Health maximum contaminant level; MCL-US, USEPA maximum contaminant level; RSD5-US, USEPA risk specific dose at a risk factor of $10^{-5}$. Other abbreviations: CAS, Chemical Abstract Service; LRL, laboratory reporting level; IRL, interim reporting level; $\mathrm{D}$, detected in groundwater samples ( $\underline{\text { table } 6 \mathrm{~B}}$ ); na, not available; $\mu \mathrm{g} / \mathrm{L}$, micrograms per liter; - , not detected]

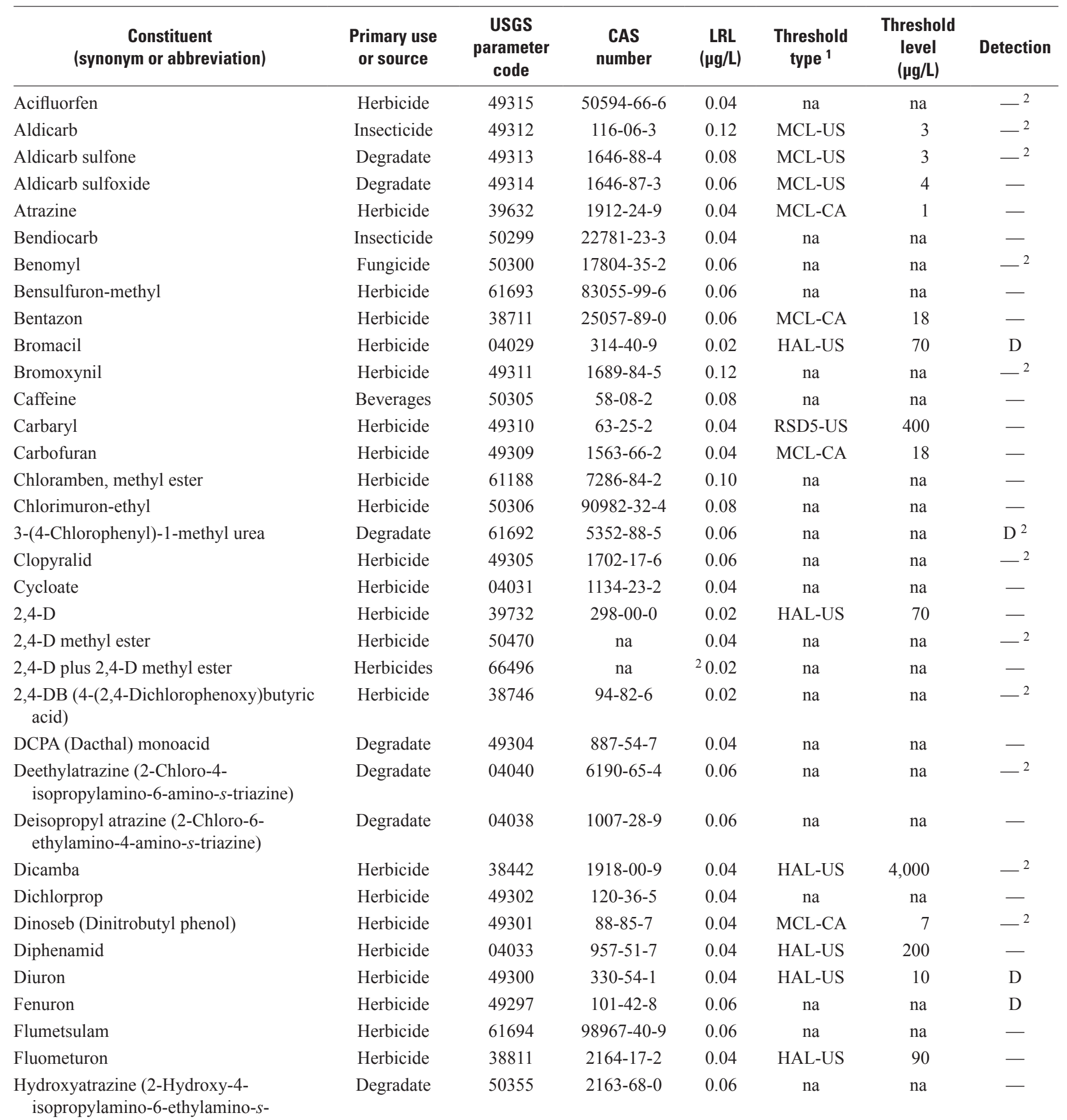
triazine) 
Table 3C. Polar pesticides and metabolites, primary uses or sources, comparative thresholds, and reporting information for the U.S. Geological Survey (USGS) National Water Quality Laboratory Schedule 2060.-Continued

[The five-digit USGS parameter code is used to uniquely identify a specific constituent or property. Laboratory reporting level, interim reporting level, threshold type, and threshold level as of November 17, 2008. Threshold type: HAL-US, U.S. Environmental Protection Agency (USEPA) lifetime health advisory; MCL-CA, California Department of Public Health maximum contaminant level; MCL-US, USEPA maximum contaminant level; RSD5-US, USEPA risk specific dose at a risk factor of $10^{-5}$. Other abbreviations: CAS, Chemical Abstract Service; LRL, laboratory reporting level; IRL, interim reporting level; $\mathrm{D}$, detected in groundwater samples (table 6B); na, not available; $\mu \mathrm{g} / \mathrm{L}$, micrograms per liter; - , not detected]

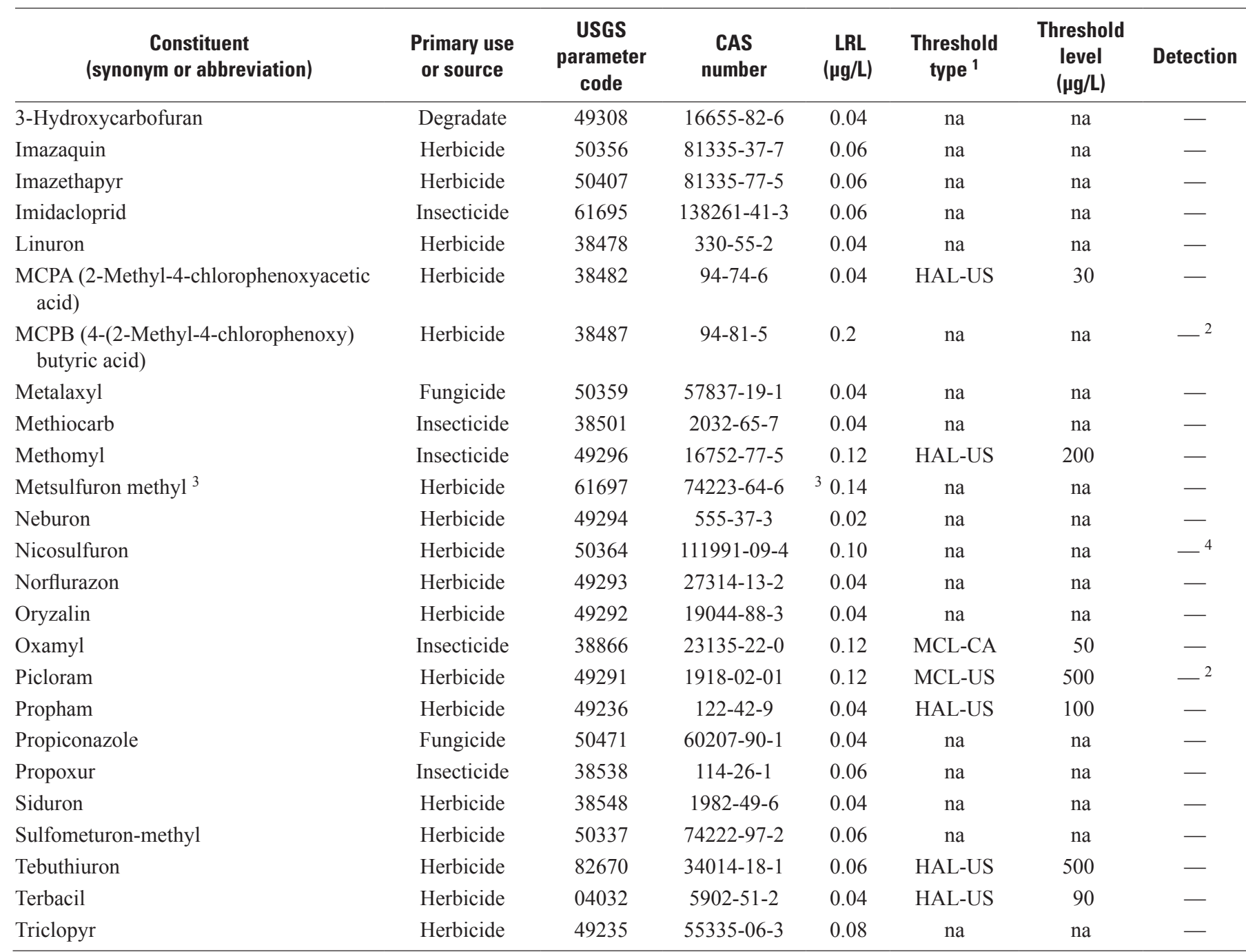

\footnotetext{
${ }^{1}$ Maximum contaminant level thresholds are listed as MCL-US when the MCL-US and MCL-CA are identical, and as MCL-CA when the MCL-CA is lower than the MCL-US or no MCL-US exists.

${ }^{2}$ The median matrix-spike recovery was less than 70 percent. Low recoveries may indicate that the compound might not have been detected in some samples if it was present at very low concentrations.

${ }^{3}$ Value is an IRL rather than an LRL

${ }^{4}$ The median laboratory matrix-spike recovery was greater than 130 percent. High recoveries may indicate that reported values could be higher than what is in the sample.
} 
Table 3D. Pharmaceutical compounds, primary uses or sources, comparative thresholds, and reporting information for the U.S. Geological Survey (USGS) National Water Quality Laboratory Schedule 2080.

[The five-digit USGS parameter code is used to uniquely identify a specific constituent or property. Abbreviations: CAS, Chemical Abstract Service; MDL, method detection limit; na, not available; $\mu \mathrm{g} / \mathrm{L}$, micrograms per liter]

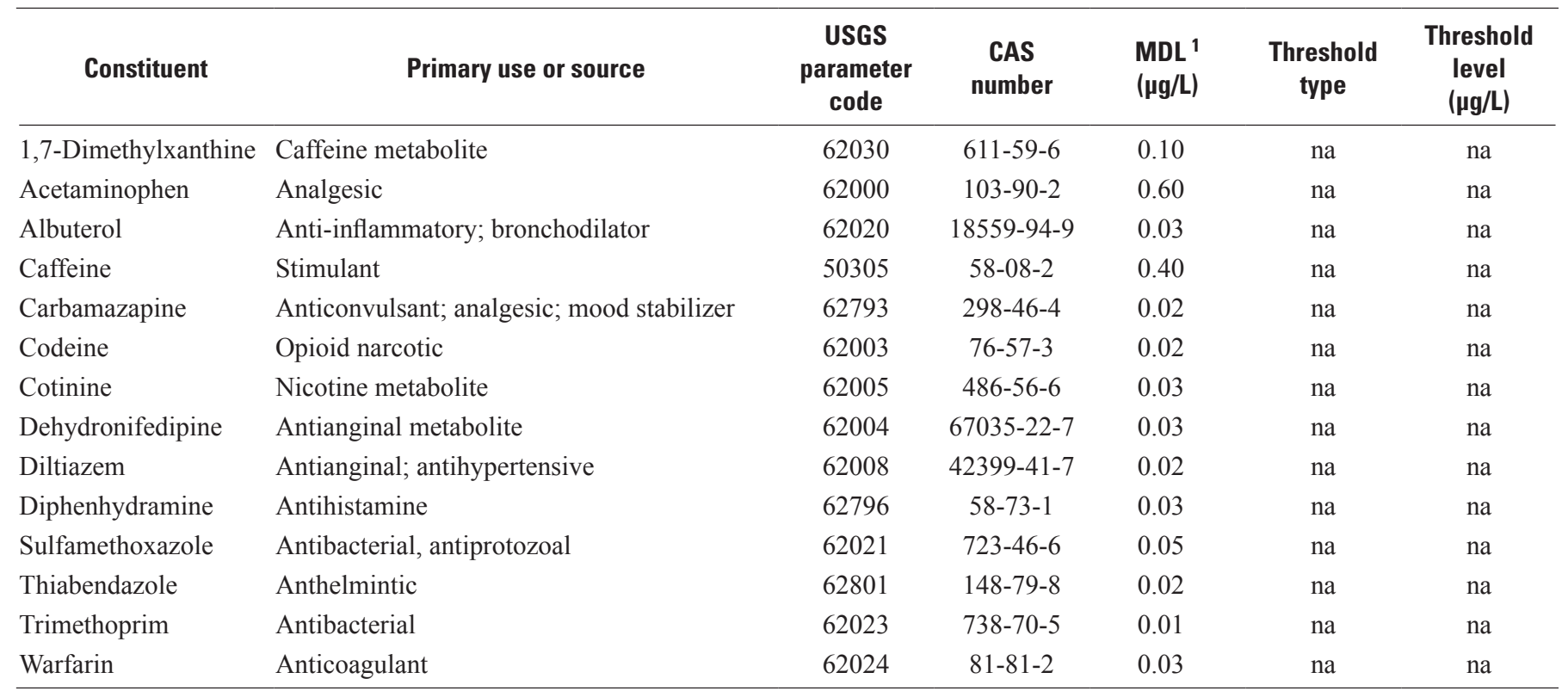

\footnotetext{
${ }^{1}$ The California Groundwater Ambient Monitoring and Assessment (GAMA) program uses uses reporting limits for the pharmaceutical compounds that are more conservative than those recommended by the USGS National Water Quality Laboratory. For albuterol, carbamazepine, codeine, dehydronifedipine, diltiazem, sulfamethoxazole, thiabendazole, trimethoprim, and warfarin, the MDL corresponds to the long-term method detection limit determined by the USGS Branch of Quality Systems in October 2007 (BQS LT-MDL). For acetaminophen, caffeine, cotinine, diphenhydramine, and xanthine, the MDL corresponds to the study reporting levels determined from assessing quality-control data associated with GAMA samples collected from May 2004 through September 2007 (GAMA SRL). The GAMA SRLs are higher than the BQS LT-MDL for those compounds. Concentrations reported by the USGS National Water Quality Laboratory that are lower than the BQS LT-MDL or GAMA SRL are reported as non-detections by the GAMA program. Results for pharmaceutical compounds from the GAMA SCRC study unit will be included in a subsequent report.
} 
Table 3E. Constituents of special interest (perchlorate, $N$-nitrosodimethylamine [NDMA], and 1,2,3-TCP), primary uses or sources, comparative thresholds, and reporting information for Weck Laboratories, Inc. analyses.

[The five-digit U.S. Geological Survey (USGS) parameter code is used to uniquely identify a specific constituent or property. Minimum reporting level, threshold type, and threshold level as of November 17, 2008. Threshold type: HAL-US, U.S. Environmental Protection Agency lifetime health advisory; MCL-CA, California Department of Public Health (CDPH) maximum contaminant level; NL-CA, CDPH notification level. Other abbreviations: CAS, Chemical Abstract Service; MRL, minimum reporting level; D, detected in groundwater samples (table 7); $\mu \mathrm{g} / \mathrm{L}$, micrograms per liter; —, not detected]

\begin{tabular}{|c|c|c|c|c|c|c|c|}
\hline $\begin{array}{c}\text { Constituent } \\
\text { (synonym or abbreviation) }\end{array}$ & $\begin{array}{l}\text { Primary use } \\
\text { or source }\end{array}$ & $\begin{array}{c}\text { USGS } \\
\text { parameter } \\
\text { code }\end{array}$ & $\begin{array}{c}\text { CAS } \\
\text { number }\end{array}$ & $\begin{array}{c}\text { MRL } \\
(\mu \mathrm{g} / \mathrm{L})\end{array}$ & $\begin{array}{l}\text { Threshold } \\
\text { type }^{1}\end{array}$ & $\begin{array}{c}\text { Threshold } \\
\text { level } \\
(\mu \mathrm{g} / \mathrm{L})\end{array}$ & Detection \\
\hline $\begin{array}{l}N \text {-nitrosodimethylamine } \\
\text { (NDMA) }\end{array}$ & Disinfection by-product & 34438 & $62-75-9$ & 0.002 & NL-CA & 0.010 & - \\
\hline $1,2,3-\mathrm{TCP}$ & Fumigant, solvent & 77443 & $96-18-4$ & 0.005 & HAL-US & 40 & - \\
\hline
\end{tabular}

\footnotetext{
${ }^{1}$ Maximum contaminant level thresholds are listed as MCL-US when the MCL-US and MCL-CA are identical, and as MCL-CA when the MCL-CA is lower than the MCL-US or no MCL-US exists.
} 
Table 3F. Trace elements, comparative thresholds, and reporting information for the U.S. Geological Survey (USGS) National Water Quality Laboratory Schedule 1948.

[The five-digit USGS parameter code is used to uniquely identify a specific constituent or property. Laboratory reporting level, threshold type, and threshold level as of November 17, 2008. Threshold type: AL-US, U.S. Environmental Protection Agency (USEPA) action level; HAL-US, USEPA lifetime health advisory level; MCL-CA, California Department of Public Health (CDPH) maximum contaminant level; MCL-US, USEPA maximum contaminant level; NL-CA, CDPH notification level; SMCL-CA, CDPH secondary maximum contaminant level. Other abbreviations: BQS, USGS Office of Water Quality Branch of Quality Systems; CAS, Chemical Abstract Service; LRL, laboratory reporting level; SRL, study reporting limit; D, detected in groundwater samples (table 8); na, not available; $\mu \mathrm{g} / \mathrm{L}$, micrograms per liter]

\begin{tabular}{|c|c|c|c|c|c|c|}
\hline Constituent & $\begin{array}{c}\text { USGS } \\
\text { parameter } \\
\text { code }\end{array}$ & $\begin{array}{c}\text { CAS } \\
\text { number }\end{array}$ & $\begin{array}{c}\text { LRL/SRL1 }^{1} \\
(\mu \mathrm{g} / \mathrm{L})\end{array}$ & $\begin{array}{c}\text { Threshold } \\
\text { type }^{2}\end{array}$ & $\begin{array}{c}\text { Threshold } \\
\text { level } \\
\text { ( } \mu \mathrm{g} / \mathrm{L})\end{array}$ & Detection \\
\hline Aluminum & 01106 & $7429-90-5$ & ${ }^{1} 1.6$ & MCL-CA & 1,000 & $\mathrm{D}$ \\
\hline Antimony & 01095 & $7440-36-0$ & 0.04 & MCL-US & 6 & $\mathrm{D}$ \\
\hline Arsenic & 01000 & $7440-38-2$ & 0.06 & MCL-US & 10 & $\mathrm{D}$ \\
\hline Barium & 01005 & $7440-39-3$ & ${ }^{1} 0.36$ & MCL-CA & 1,000 & $\mathrm{D}$ \\
\hline Beryllium & 01010 & $7440-41-7$ & 0.02 & MCL-US & 4 & $\mathrm{D}$ \\
\hline Boron & 01020 & $7440-42-8$ & 4 & NL-CA & 1,000 & $\mathrm{D}$ \\
\hline Cadmium & 01025 & $7440-43-9$ & 0.02 & MCL-US & 5 & $\mathrm{D}$ \\
\hline Chromium & 01030 & $7440-47-3$ & ${ }^{1} 0.42$ & MCL-CA & 50 & $\mathrm{D}$ \\
\hline Cobalt & 01035 & $7440-48-4$ & 0.02 & na & na & $\mathrm{D}$ \\
\hline Copper & 01040 & $7440-50-8$ & ${ }^{1} 1.7$ & AL-US & 1,300 & $\mathrm{D}$ \\
\hline Iron & 01046 & $7439-89-6$ & ${ }^{1} 6$ & SMCL-CA & 300 & $\mathrm{D}$ \\
\hline Lead & 01049 & $7439-92-1$ & ${ }^{1} 0.65$ & AL-US & 15 & $\mathrm{D}$ \\
\hline Lithium & 01130 & $7439-93-2$ & 1 & na & na & $\mathrm{D}$ \\
\hline Manganese & 01056 & $7439-96-5$ & ${ }^{1} 0.2$ & SMCL-CA & 50 & $\mathrm{D}$ \\
\hline Mercury & 71890 & 7439-97-6 & ${ }^{1} 0.012$ & MCL-US & 2 & $\mathrm{D}$ \\
\hline Molybdenum & 01060 & 7439-98-7 & 0.02 & HAL-US & 40 & $\mathrm{D}$ \\
\hline Nickel & 01065 & $7440-02-0$ & ${ }^{1} 0.36$ & MCL-CA & 100 & $\mathrm{D}$ \\
\hline Selenium & 01145 & $7782-49-2$ & 0.06 & MCL-US & 50 & $\mathrm{D}$ \\
\hline Silver & 01075 & $7440-22-4$ & 0.008 & SMCL-CA & 100 & $\mathrm{D}$ \\
\hline Strontium & 01080 & $7440-24-6$ & 0.8 & HAL-US & 4,000 & $\mathrm{D}$ \\
\hline Thallium & 01057 & $7440-28-0$ & 0.04 & MCL-US & 2 & $\mathrm{D}$ \\
\hline Tungsten & 01155 & $7440-33-7$ & 0.11 & na & na & $\mathrm{D}$ \\
\hline Uranium & 22703 & $7440-61-1$ & 0.006 & MCL-US & 30 & $\mathrm{D}$ \\
\hline Vanadium & 01085 & $7440-62-2$ & ${ }^{1} 0.11$ & NL-CA & 50 & $\mathrm{D}$ \\
\hline Zinc & 01090 & $7440-66-6$ & ${ }^{1} 4.8$ & SMCL-CA $^{3}$ & 5,000 & $\mathrm{D}$ \\
\hline
\end{tabular}

\footnotetext{
${ }^{1}$ Study reporting limit (SRL) defined based on examination of GAMA quality-control (QC) samples collected from May 2004 through January 2008 (Olsen and others, 2010). Values below SRL are reported as less than or equal to the value reported by the laboratory ( $\leq$ ). In the USGS National Water Information System database, the result is accompanied with the following comment: Result is $<$ or = reported value, based on QC data (may include: field blanks, sourcesolution blanks, trip blanks, National Water Quality Laboratory (NWQL) set blanks, NWQL blank water certificates, and USGS BQS Blind Blank Program data).

${ }^{2}$ Maximum contaminant level thresholds are listed as MCL-US when the MCL-US and MCL-CA are identical, and as MCL-CA when the MCL-CA is lower than the MCL-US or no MCL-US exists.

${ }^{3}$ The secondary maximum contaminant level for zinc is listed as SMCL-CA since SMCLs established by CDPH are used in this report for all constituents that have SMCL-CA values.
} 
Table 3G. Nutrients and dissolved organic carbon (DOC), comparative thresholds, and reporting information for the U.S. Geological Survey (USGS) National Water Quality Laboratory Schedules 2755 and 2702 and Laboratory Code 2612.

[The five-digit USGS parameter code is used to uniquely identify a specific constituent or property. Laboratory reporting level, threshold type, and threshold level as of November 17, 2008. Threshold type: HAL-US, U.S. Environmental Protection Agency (USEPA) lifetime health advisory level; MCL-US, USEPA maximum contaminant level. Other abbreviations: CAS, Chemical Abstract Service; LRL, laboratory reporting level; D, detected in groundwater samples (table 9); na, not available; $\mathrm{mg} / \mathrm{L}$, milligrams per liter]

\begin{tabular}{|c|c|c|c|c|c|c|}
\hline Constituent & $\begin{array}{c}\text { USGS } \\
\text { parameter } \\
\text { code }\end{array}$ & $\begin{array}{c}\text { CAS } \\
\text { number }\end{array}$ & $\begin{array}{c}\mathrm{LRL} \\
(\mathrm{mg} / \mathrm{L})\end{array}$ & $\begin{array}{l}\text { Threshold } \\
\text { type }^{1}\end{array}$ & $\begin{array}{c}\text { Threshold } \\
\text { level } \\
\text { (mg/L) }\end{array}$ & Detection \\
\hline $\begin{array}{l}\text { Ammonia plus organic nitrogen } \\
\text { (as nitrogen) }\end{array}$ & 00623 & na & 0.1 & na & na & $\mathrm{D}$ \\
\hline $\begin{array}{l}\text { Ammonia plus organic nitrogen } \\
\text { (as nitrogen), unfiltered }\end{array}$ & 00625 & $17778-88-0$ & 0.1 & na & na & $\mathrm{D}$ \\
\hline Nitrate plus nitrite (as nitrogen) & 00631 & na & 0.04 & MCL-US & 10 & $\mathrm{D}$ \\
\hline Nitrite (as nitrogen) & 00613 & $14797-65-0$ & 0.002 & MCL-US & 1 & $\mathrm{D}$ \\
\hline $\begin{array}{l}\text { Total nitrogen (ammonia, nitrite, nitrate, } \\
\text { organic nitrogen) }\end{array}$ & 62854 & $17778-88-0$ & 0.06 & na & na & $\mathrm{D}$ \\
\hline Phosphate, orthophosphate (as phosphorus) & 00671 & $14265-44-2$ & 0.006 & na & na & $\mathrm{D}$ \\
\hline
\end{tabular}

\footnotetext{
${ }^{1}$ Maximum contaminant level thresholds are listed as MCL-US when the MCL-US and MCL-CA are identical, and as MCL-CA when the MCL-CA is lower than the MCL-US or no MCL-US exists.

${ }^{2}$ The HAL-US is $30 \mathrm{mg} / \mathrm{L}$ "as ammonia." To facilitate comparison to the analytical results, we have converted and reported this HAL-US as $24.7 \mathrm{mg} / \mathrm{L}$ "as nitrogen."
} 
Table 3H. Major and minor ions, silica, total dissolved solids (TDS), and alkalinity, comparative thresholds, and reporting information for the U.S. Geological Survey (USGS) National Water Quality Laboratory Schedule 1948.

[The five-digit USGS parameter code is used to uniquely identify a specific constituent or property. Laboratory reporting level, threshold type, and threshold level as of November 17, 2008. Threshold type: MCL-CA, California Department of Public Health (CDPH) maximum contaminant level; SMCL-CA, CDPH secondary maximum contaminant level. Other abbreviations: CAS, Chemical Abstract Service; LRL, laboratory reporting level; D, detected in groundwater samples (table 10); na, not available; $\mathrm{mg} / \mathrm{L}$, milligrams per liter; $\mathrm{SiO}_{2}$, silicon dioxide; $\mathrm{CaCO}_{3}$, calcium carbonate]

\begin{tabular}{|c|c|c|c|c|c|c|}
\hline Constituent & $\begin{array}{c}\text { USGS } \\
\text { parameter } \\
\text { code }\end{array}$ & CAS number & $\begin{array}{c}\mathrm{LRL} \\
(\mathrm{mg} / \mathrm{L})\end{array}$ & $\begin{array}{l}\text { Threshold } \\
\text { type }\end{array}$ & $\begin{array}{c}\text { Threshold } \\
\text { level } \\
\text { (mg/L) }\end{array}$ & Detection \\
\hline Bromide & 71870 & $24959-67-9$ & 0.02 & na & na & $\mathrm{D}$ \\
\hline Calcium & 00915 & $7440-70-2$ & 0.02 & na & na & $\mathrm{D}$ \\
\hline Chloride & 00940 & $16887-00-6$ & 0.12 & SMCL-CA & ${ }^{2} 250(500)$ & $\mathrm{D}$ \\
\hline Fluoride & 00950 & $16984-48-8$ & 0.08 & MCL-CA & 2 & $\mathrm{D}$ \\
\hline Iodide & 71865 & $7553-56-2$ & 0.002 & na & na & $\mathrm{D}$ \\
\hline Magnesium & 00925 & $7439-95-4$ & 0.012 & na & na & $\mathrm{D}$ \\
\hline Potassium & 00935 & 7440-09-7 & 0.06 & na & na & $\mathrm{D}$ \\
\hline Silica (as $\mathrm{SiO}_{2}$ ) & 00955 & $7631-86-9$ & 0.02 & na & na & $\mathrm{D}$ \\
\hline Sodium & 00930 & $7440-23-5$ & 0.12 & na & na & $\mathrm{D}$ \\
\hline Sulfate & 00945 & $14808-79-8$ & 0.18 & SMCL-CA & ${ }^{2} 250(500)$ & $\mathrm{D}$ \\
\hline $\begin{array}{l}\text { Residue on evaporation (total } \\
\text { dissolved solids, TDS) }\end{array}$ & 70300 & na & 10 & SMCL-CA & ${ }^{2} 500(1,000)$ & $\mathrm{D}$ \\
\hline Laboratory alkalinity (as $\left.\mathrm{CaCO}_{3}\right)^{3}$ & 29801 & na & 1 & na & na & $\mathrm{D}$ \\
\hline
\end{tabular}

\footnotetext{
${ }^{1}$ Maximum contaminant level thresholds are listed as MCL-US when the MCL-US and MCL-CA are identical, and as MCL-CA when the MCL-CA is lower than the MCL-US or no MCL-US exists.

${ }^{2}$ The recommended SMCL-CA thresholds for chloride, sulfate, and TDS are listed with the upper SMCL-CA thresholds in parentheses.

${ }^{3}$ Laboratory alkalinity results are presented in table 4.
}

Table 3I. Arsenic and iron species, comparative thresholds, and reporting information for the U.S. Geological Survey (USGS) Trace Metal Laboratory, Boulder, Colorado analyses.

[The five-digit USGS parameter code is used to uniquely identify a specific constituents or property. Method detection limit, threshold type, and threshold level as of November 17, 2008. Threshold type: MCL-US, U.S. Environmental Protection Agency (USEPA) maximum contaminant level; SMCL-US, USEPA secondary maximum contaminant level. Other abbreviations: CAS, Chemical Abstract Service; MDL, method detection limit; na, not available; $\mu \mathrm{g} / \mathrm{L}$, micrograms per liter; D, detected in groundwater samples (table 11)]

\begin{tabular}{|c|c|c|c|c|c|c|}
\hline Constituent & $\begin{array}{c}\text { USGS } \\
\text { parameter } \\
\text { code }\end{array}$ & CAS number & $\begin{array}{l}\text { MDL } \\
(\mu \mathrm{g} / \mathrm{L})\end{array}$ & $\begin{array}{c}\text { Threshold } \\
\text { type }^{1}\end{array}$ & $\begin{array}{c}\text { Threshold } \\
\text { level } \\
\text { ( } \mathrm{gg} / \mathrm{L})\end{array}$ & Detection \\
\hline Arsenic (total) & 99033 & $7440-38-2$ & 0.5 & MCL-US & 10 & $\mathrm{D}$ \\
\hline Iron (II) & 01047 & $7439-89-6$ & 2 & na & na & $\mathrm{D}$ \\
\hline
\end{tabular}

\footnotetext{
${ }^{1}$ Maximum contaminant level thresholds are listed as MCL-US when the MCL-US and MCL-CA are identical, and as MCL-CA when the MCL-CA is lower
} than the MCL-US or no MCL-US exists. 
Table 3J. Isotopic and radioactive constituents, comparative thresholds, and reporting information for laboratory analyses.

[The five-digit U.S. Geological Survey (USGS) parameter code is used to uniquely identify a specific constituent or property. Stable isotope ratios are reported in the standard delta notation $(\delta)$, the ratio of a heavier isotope to more common lighter isotope of that element, relative to a standard reference material. Threshold type and threshold level as of November 17, 2008. Threshold type: MCL-CA, California Department of Public Health maximum contaminant level; MCL-US, U.S. Environmental Protection Agency maximum contaminant level. Other abbreviations: CAS, Chemical Abstract Service; CSU, combined standard uncertainty; $\mathrm{ssL}_{\mathrm{C}}$, sample-specific critical level; MRL, minimum reporting level; MU, method uncertainty; na, not available; pCi/L, picocuries per liter; $\mathrm{D}$, detected in groundwater samples (tables 12 and $\underline{14})]$

\begin{tabular}{|c|c|c|c|c|c|c|c|}
\hline Constituent & $\begin{array}{c}\text { USGS } \\
\text { parameter } \\
\text { code }\end{array}$ & $\begin{array}{c}\text { CAS } \\
\text { number }\end{array}$ & $\begin{array}{c}\text { Reporting } \\
\text { level } \\
\text { type }\end{array}$ & $\begin{array}{l}\text { Reporting } \\
\text { level or } \\
\text { uncertainty }\end{array}$ & $\begin{array}{l}\text { Threshold } \\
\text { type }^{1}\end{array}$ & $\begin{array}{l}\text { Threshold } \\
\text { level }\end{array}$ & Detection \\
\hline$\delta^{2} \mathrm{H}$ in water ${ }^{2}$ & 82082 & na & MU & 2 & na & na & $\mathrm{D}$ \\
\hline$\delta^{18} \mathrm{O}$ in water ${ }^{2}$ & 82085 & na & MU & 0.20 & na & na & $\mathrm{D}$ \\
\hline$\delta^{34} \mathrm{~S}$ in dissolved sulfate ${ }^{2}$ & 49932 & na & MRL & 0.4 & na & na & na \\
\hline$\delta^{13} \mathrm{C}$ in dissolved inorganic carbon ${ }^{3}$ & 82081 & na & 1 -sigma & 0.05 & na & na & $\mathrm{D}$ \\
\hline \multicolumn{8}{|c|}{ Radioactive constituents (percent modern) } \\
\hline Carbon- $14^{3}$ & 49933 & $14762-75-5$ & 1-sigma & 0.002 & na & na & $\mathrm{D}$ \\
\hline $\begin{array}{l}\text { Gross beta radioactivity, 72-hour and 30-day } \\
\text { counts } 5\end{array}$ & 99922,99923 & $312587-47-2$ & $\mathrm{ssL}_{\mathrm{C}}$ & $\mathrm{CSU}$ & MCL-CA & 50 & $\mathrm{D}$ \\
\hline
\end{tabular}

\footnotetext{
${ }^{1}$ Maximum contaminant level thresholds are listed as MCL-US when the MCL-US and MCL-CA are identical, and as MCL-CA when the MCL-CA is lower than the MCL-US or no MCL-US exists.

${ }^{2}$ USGS Stable Isotope Laboratory, Reston, Virginia.

${ }^{3}$ Woods Hole Oceanographic Institution, National Ocean Sciences Accelerator Mass Spectrometry Facility (NOSAMS) (contract laboratory).

${ }^{4}$ USGS Stable Isotope and Tritium Laboratory, Menlo Park, California.

${ }^{5}$ Eberline Analytical Services (contract laboratory).
} 
Table 3K. Dissolved gases and tritium, comparison thresholds and reporting information for the U.S. Geological Survey (USGS) Chlorofluorocarbon Laboratory and Lawrence Livermore National Laboratory analyses.

[The five-digit USGS parameter code is used to uniquely identify a specific constituent or property. Threshold type and threshold value as of November 17, 2008. Threshold type: MCL-CA, California Department of Public Health maximum contaminant level. Other abbreviations: CAS, Chemical Abstract Service; MU, method uncertainty; $\mu \mathrm{g} / \mathrm{L}$, micrograms per liter; mg/L, milligrams per liter; na, not available; $\mathrm{pCi} / \mathrm{L}$, picocuries per liter; $\mathrm{cm}^{3} \mathrm{STP} / \mathrm{g}$, cubic centimeters of gas at standard temperature and pressure per gram of water; D, detected in groundwater samples (table 13)]

\begin{tabular}{|c|c|c|c|c|c|c|c|}
\hline Constituent & $\begin{array}{c}\text { USGS } \\
\text { parameter } \\
\text { code }\end{array}$ & CAS number & $\begin{array}{c}\text { MU } \\
\text { (percent) }\end{array}$ & $\begin{array}{l}\text { Reporting } \\
\text { units }\end{array}$ & $\begin{array}{c}\text { Threshold } \\
\text { type }^{1}\end{array}$ & $\begin{array}{c}\text { Threshold } \\
\text { value } \\
\text { (pCi/L) }\end{array}$ & Detection \\
\hline Methane & 76994 & $74-82-8$ & na & $\mu \mathrm{g} / \mathrm{L}$ & na & na & $\mathrm{D}$ \\
\hline Carbon dioxide & 00405 & $124-39-9$ & na & $\mathrm{mg} / \mathrm{L}$ & na & na & $\mathrm{D}$ \\
\hline Argon & 82043 & $7440-37-1$ & na & $\mathrm{mg} / \mathrm{L}$ & na & na & $\mathrm{D}$ \\
\hline \multicolumn{8}{|c|}{ Dissolved noble gases ${ }^{3}$} \\
\hline Helium-3 / Helium-4 & 61040 & na / 7440-59-7 & 0.75 & atom ratio & na & na & na \\
\hline Argon & 85563 & 7440-37-1 & 2 & $\mathrm{~cm}^{3} \mathrm{STP} / \mathrm{g}$ & na & na & na \\
\hline Xenon & 85567 & $7440-63-3$ & 2 & $\mathrm{~cm}^{3} \mathrm{STP} / \mathrm{g}$ & na & na & na \\
\hline Tritium & 07000 & $10028-17-8$ & 1 & pCi/L & MCL-CA & 20,000 & na \\
\hline
\end{tabular}

\footnotetext{
${ }^{1}$ Maximum contaminant level thresholds are listed as MCL-US when the MCL-US and MCL-CA are identical, and as MCL-CA when the MCL-CA is lower than the MCL-US or no MCL-US exists.

${ }^{2}$ USGS Chlorofluorocarbon Laboratory, Reston, Virginia.

${ }^{3}$ Lawrence Livermore National Laboratory.
} 

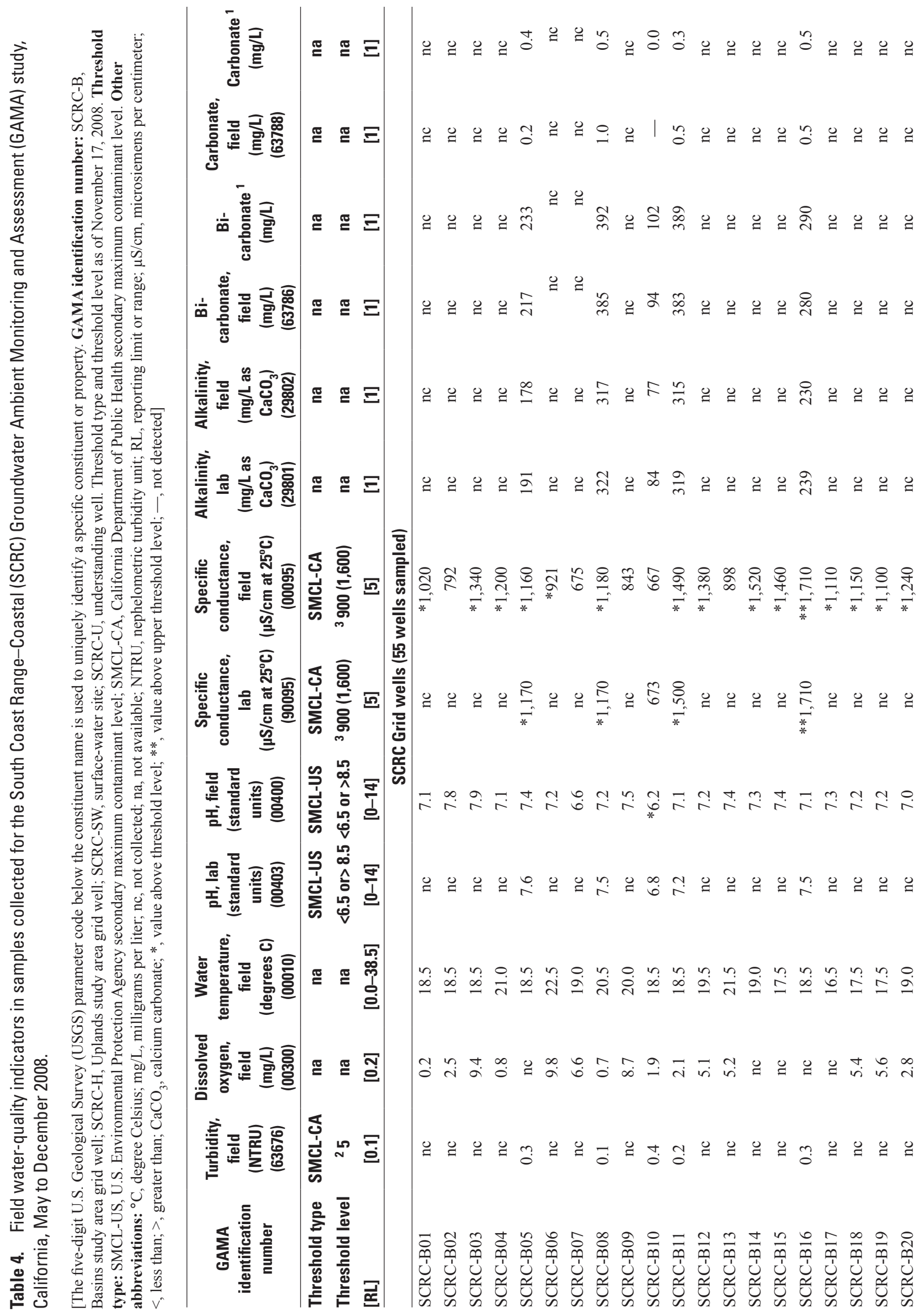


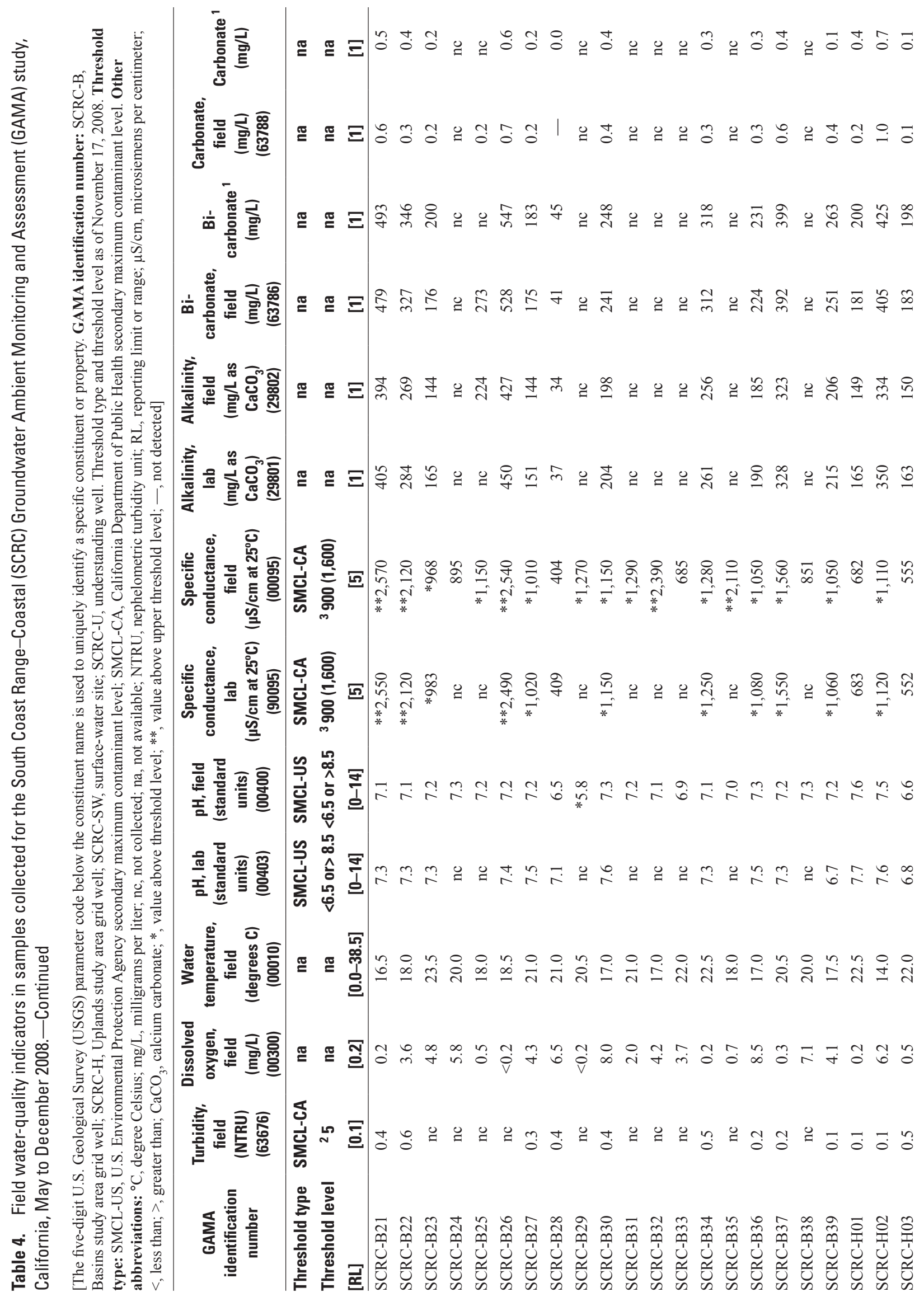




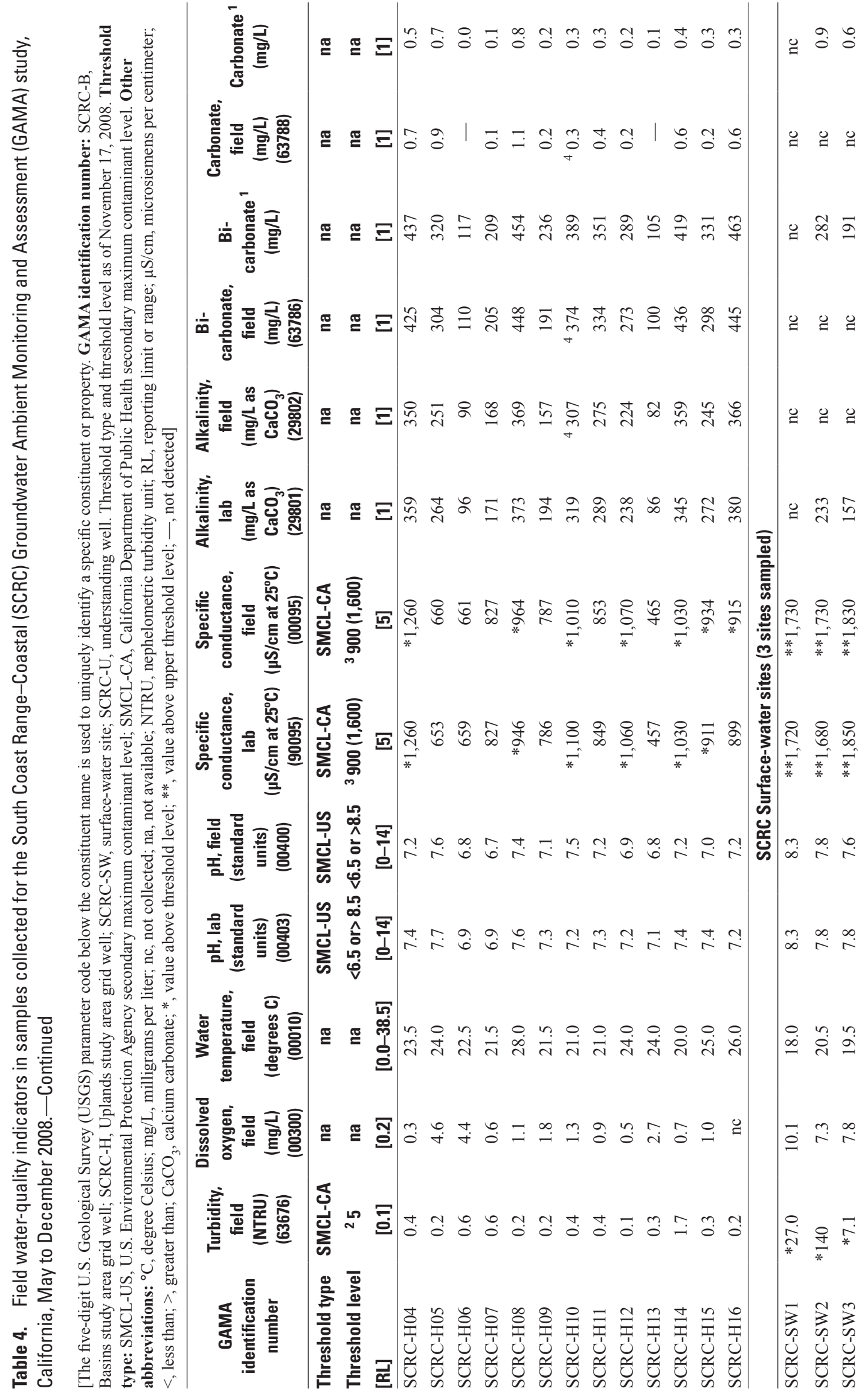




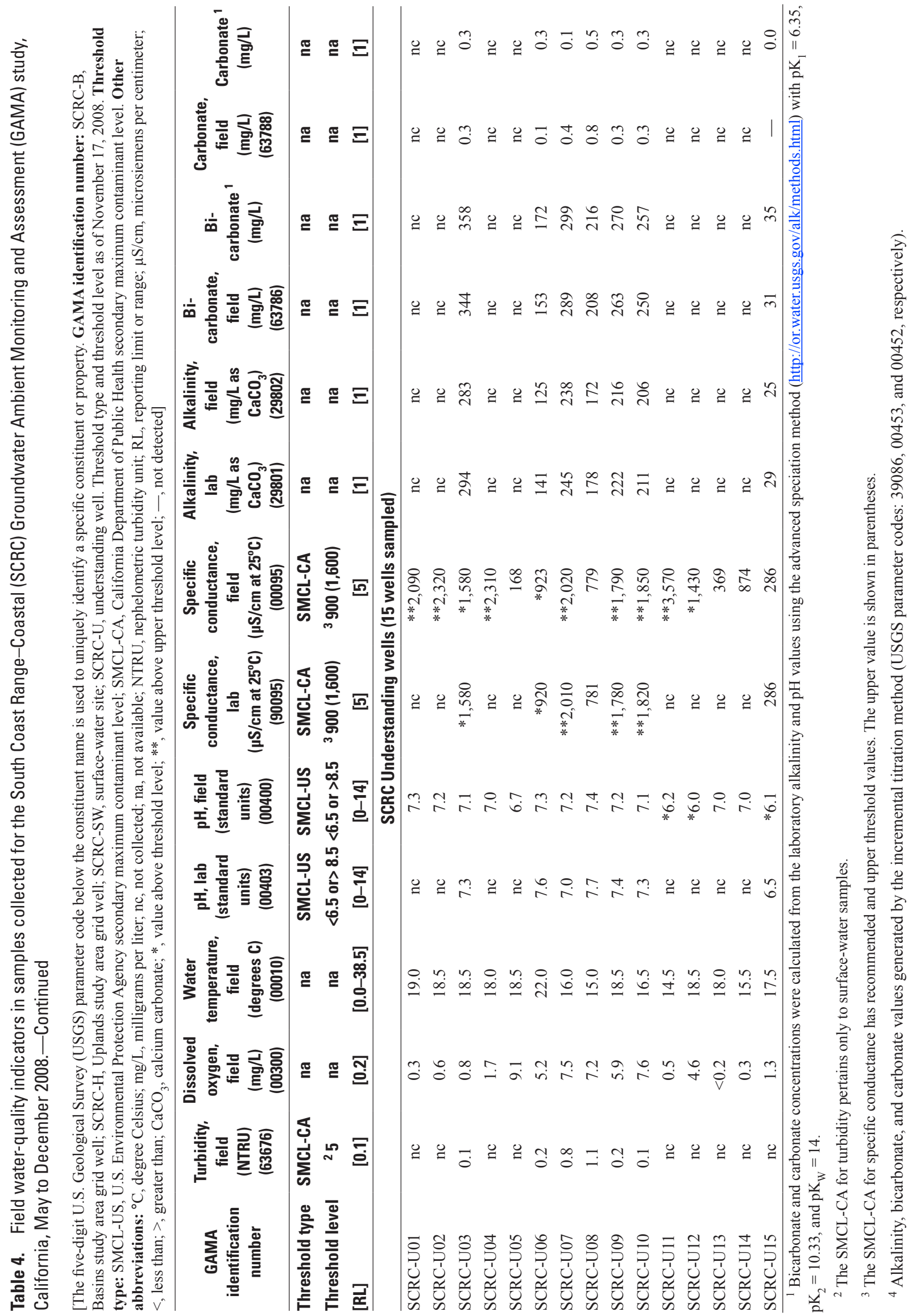




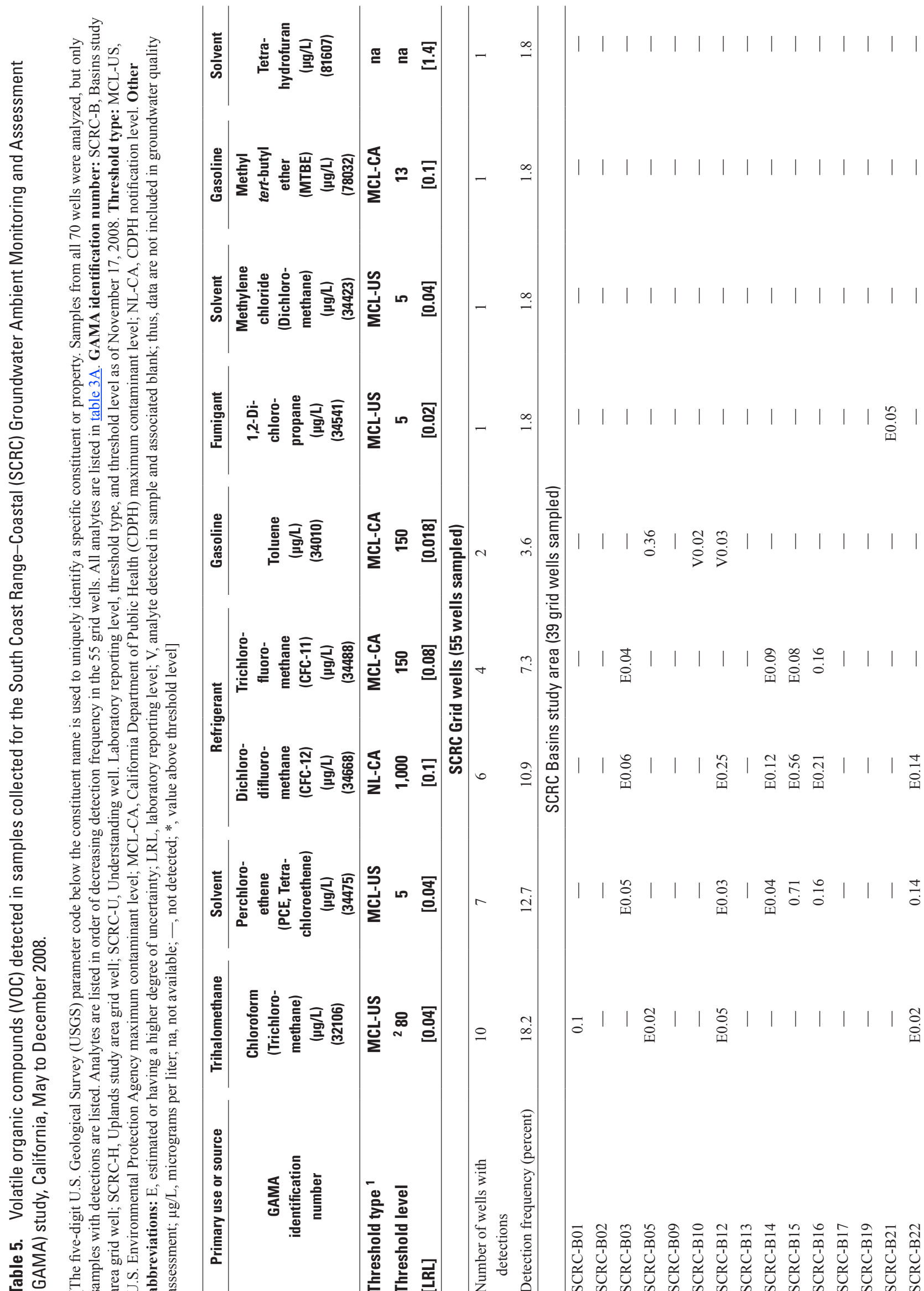




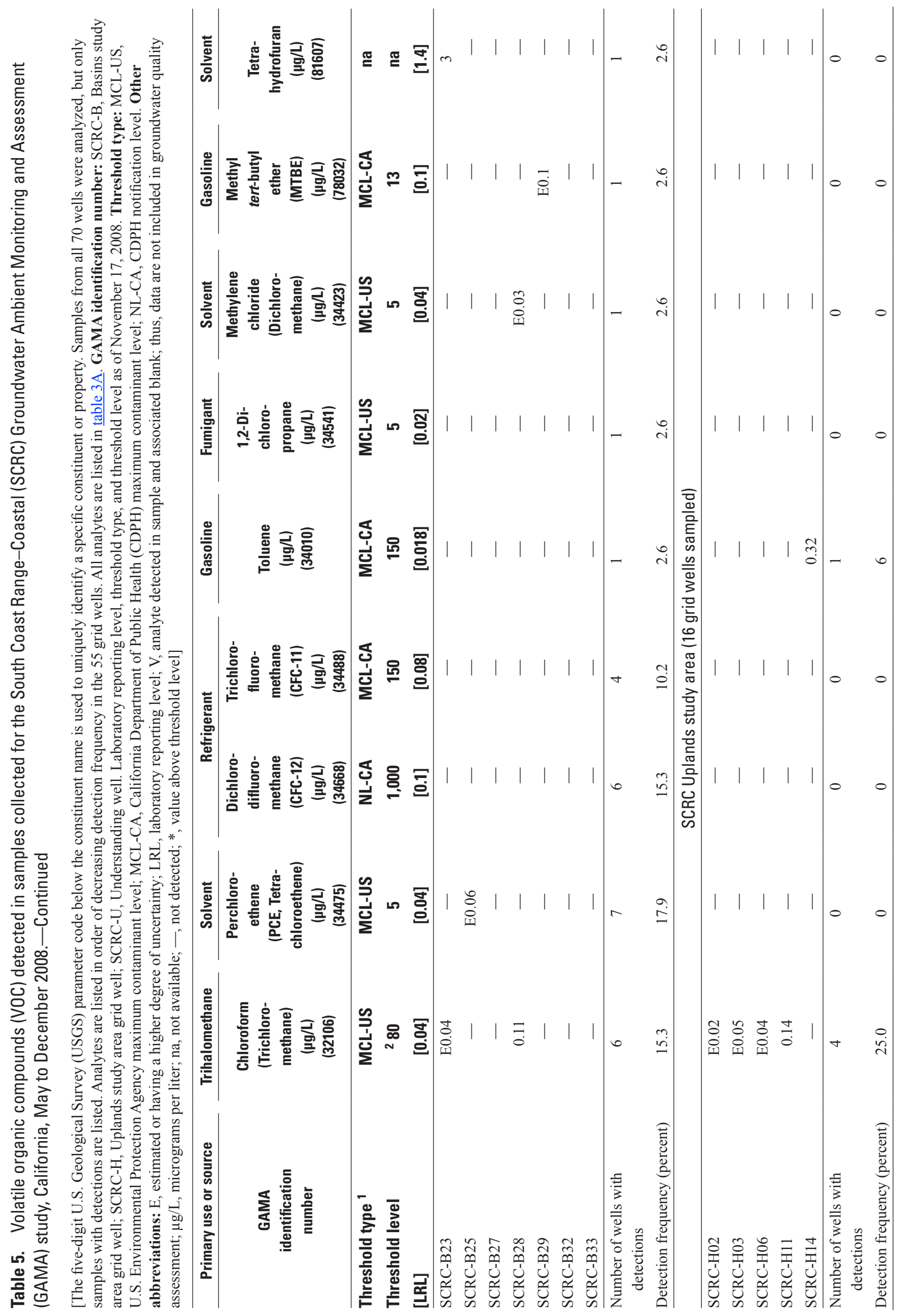




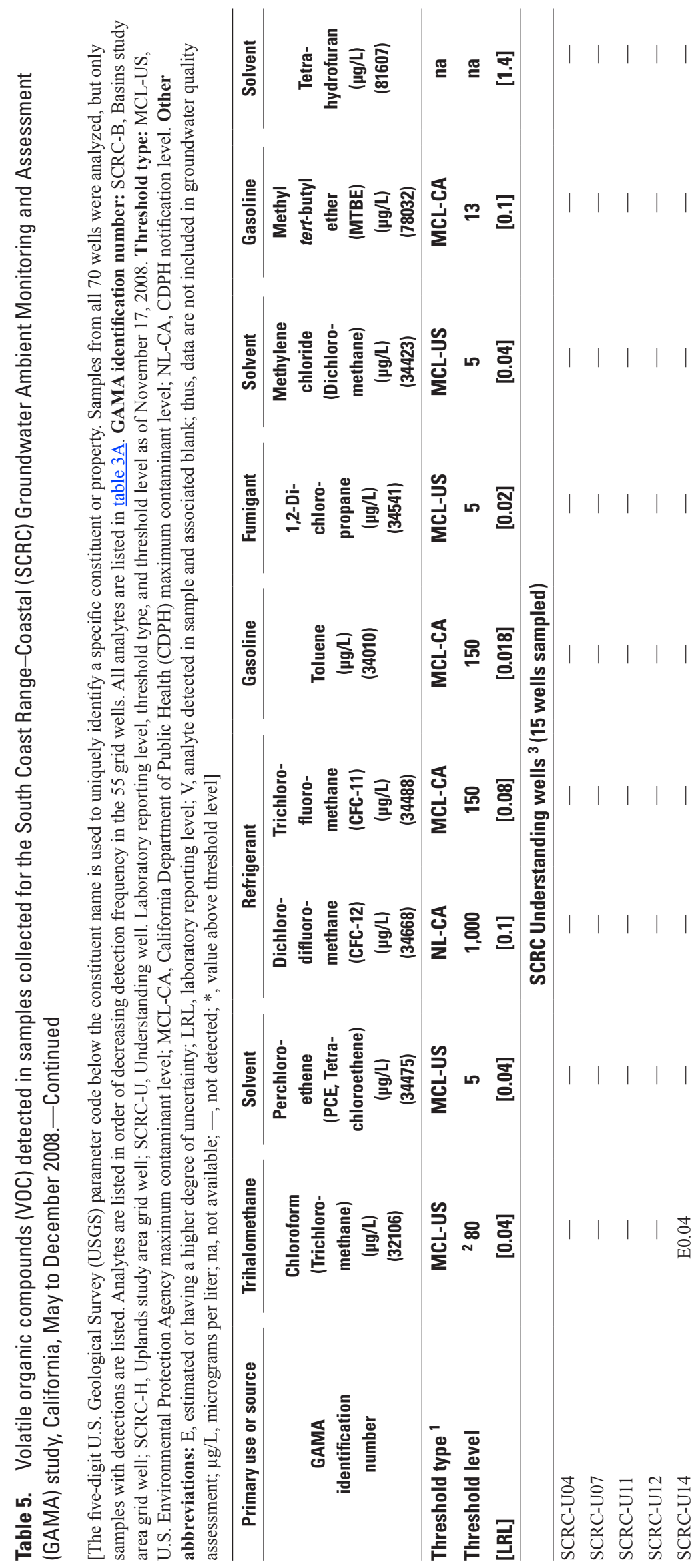




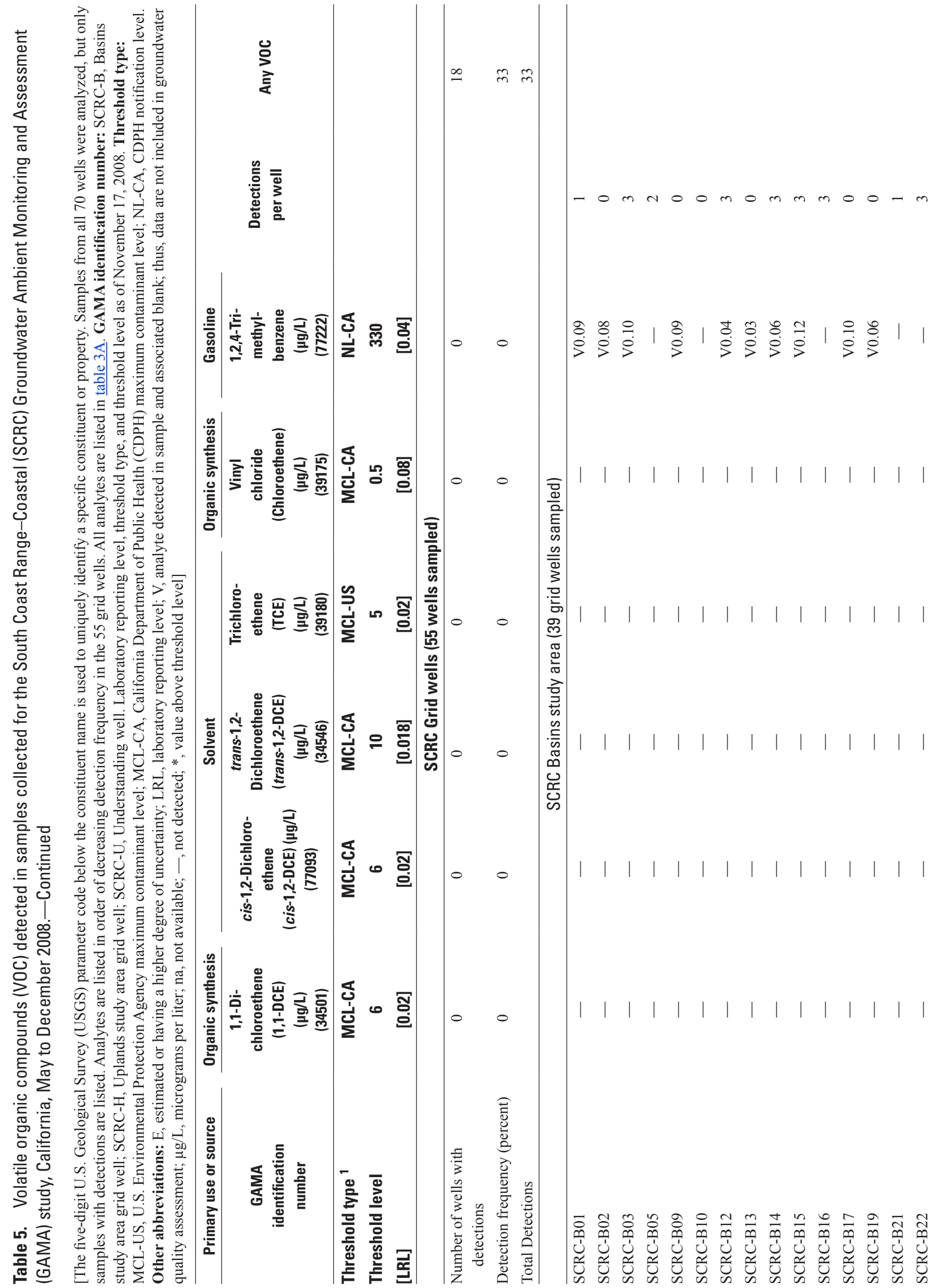




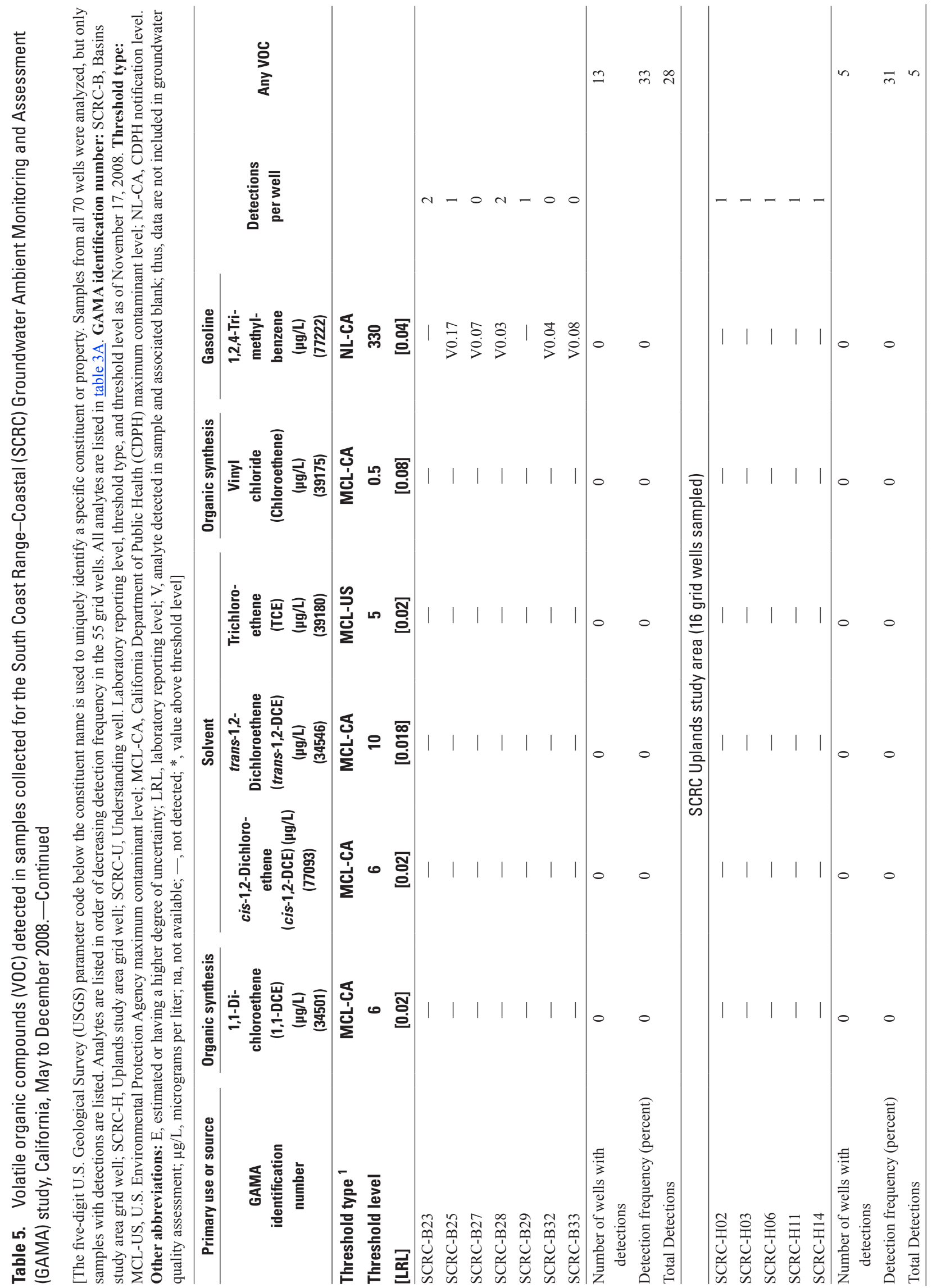




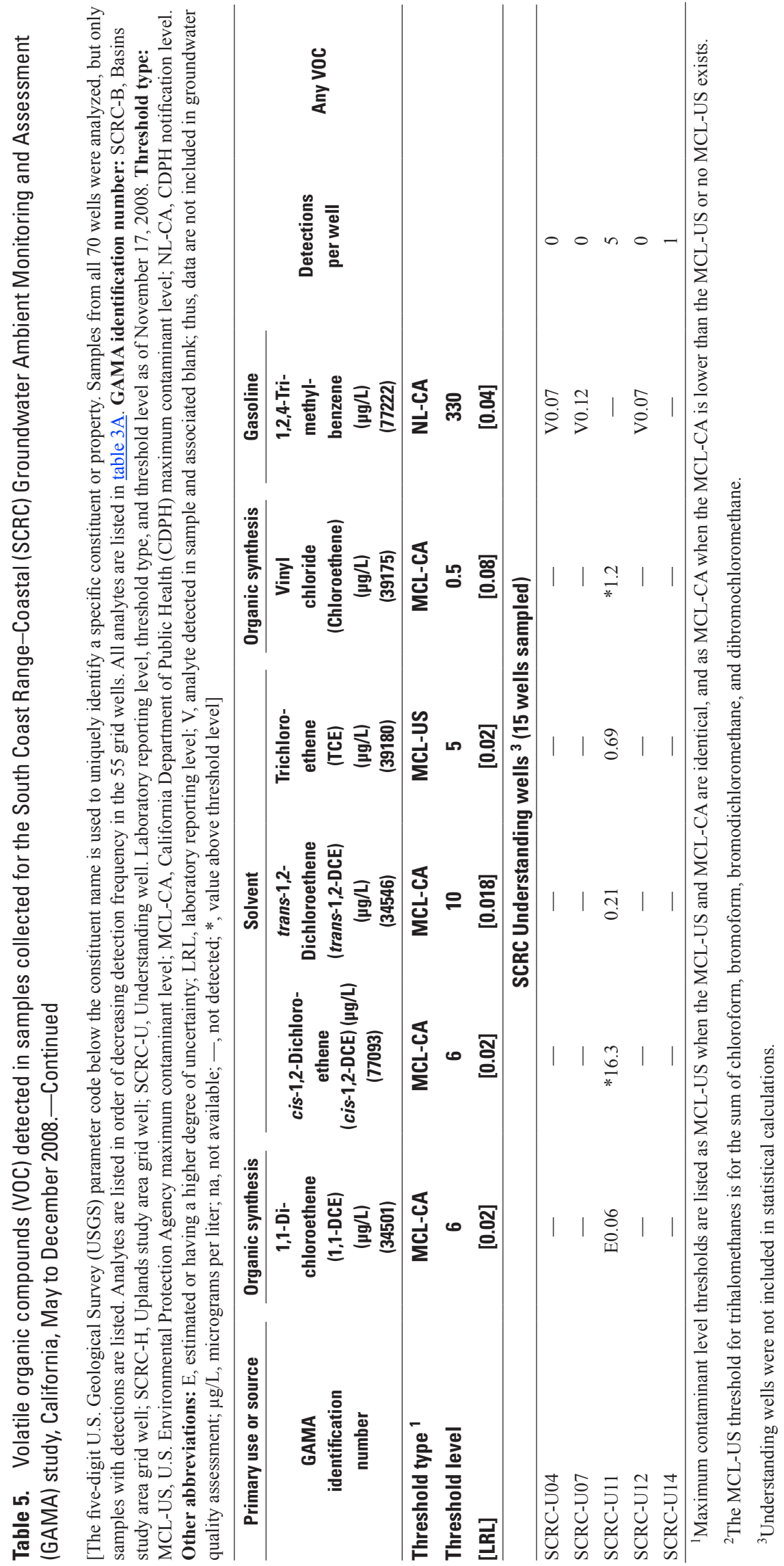




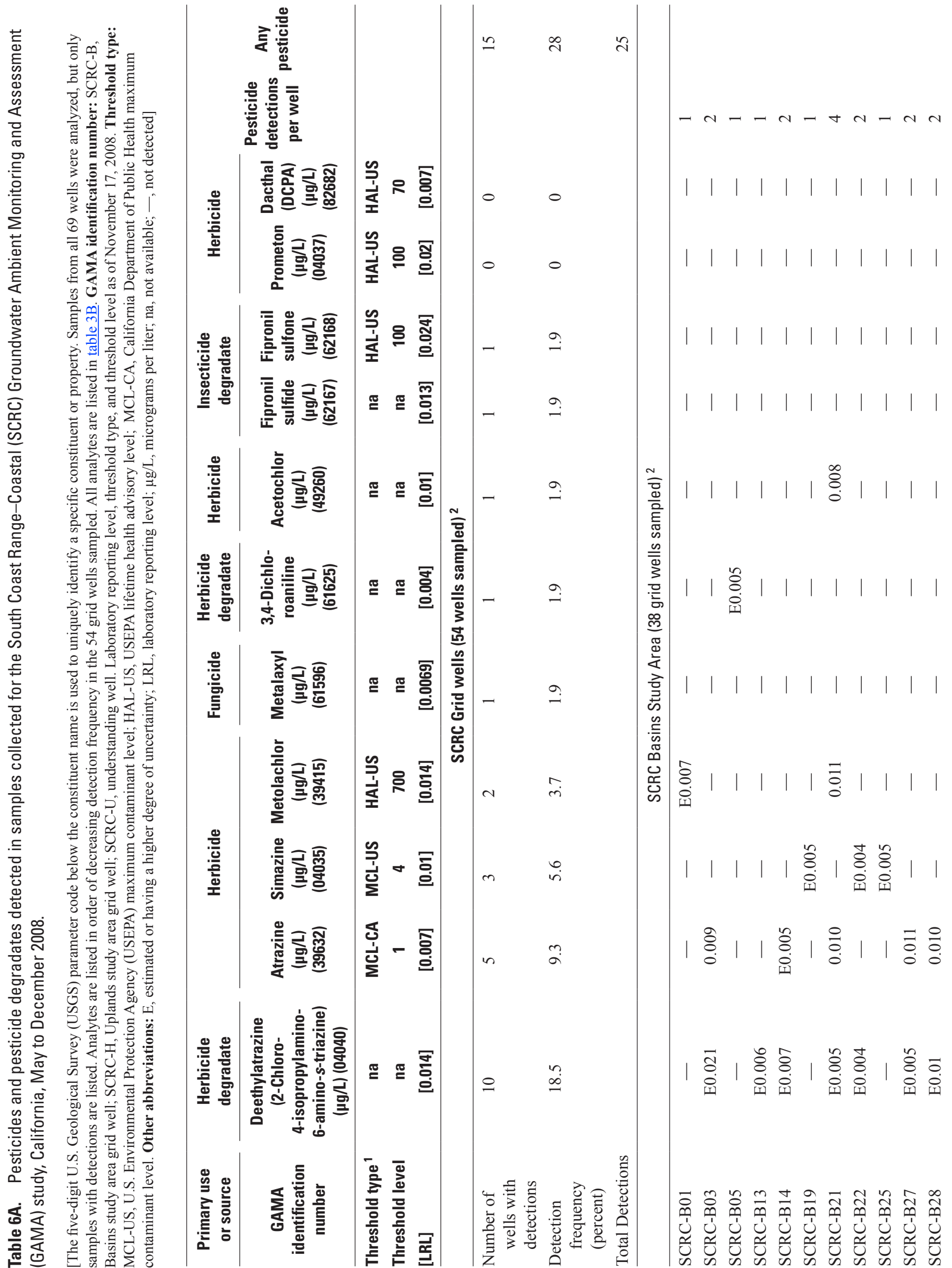




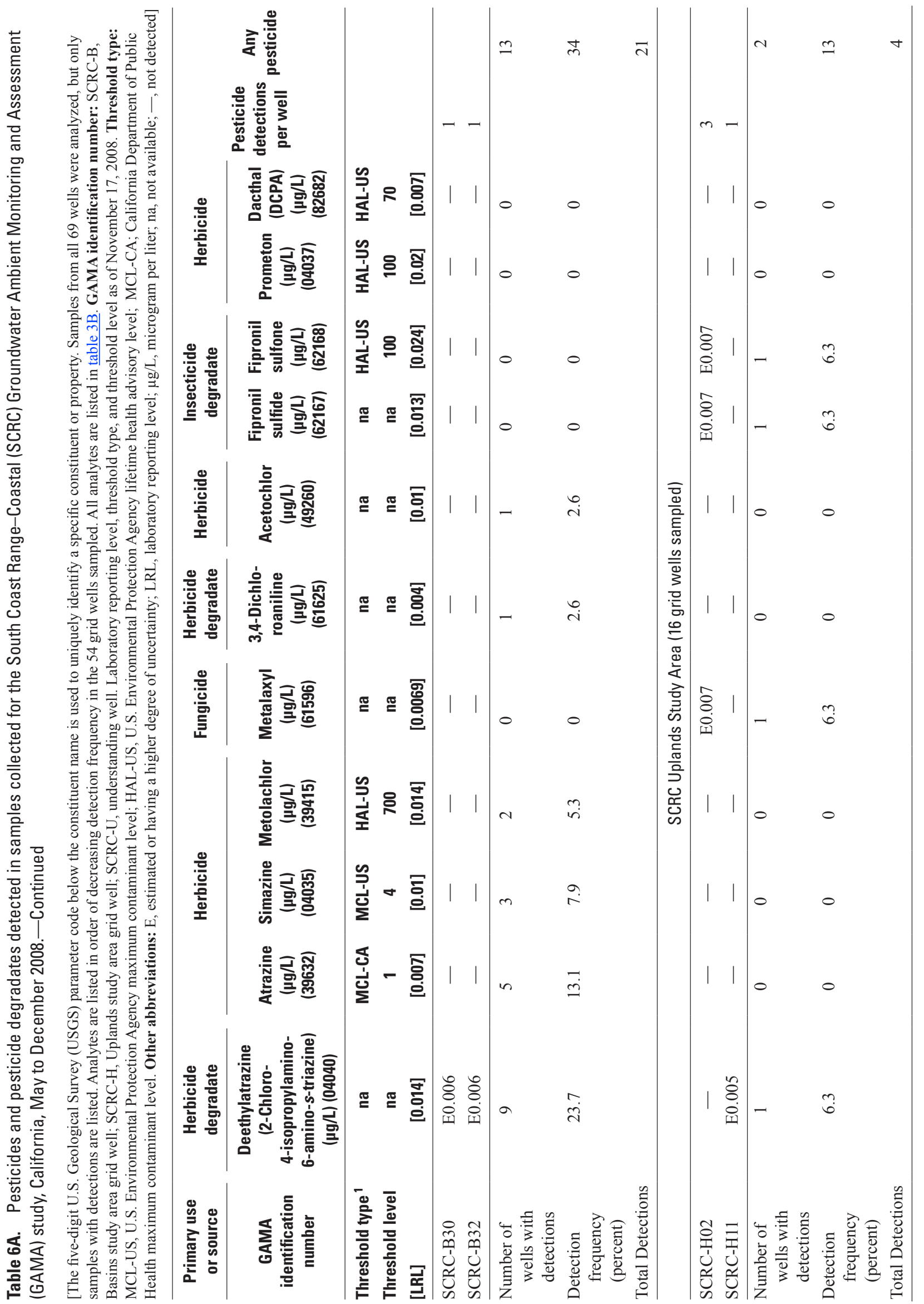




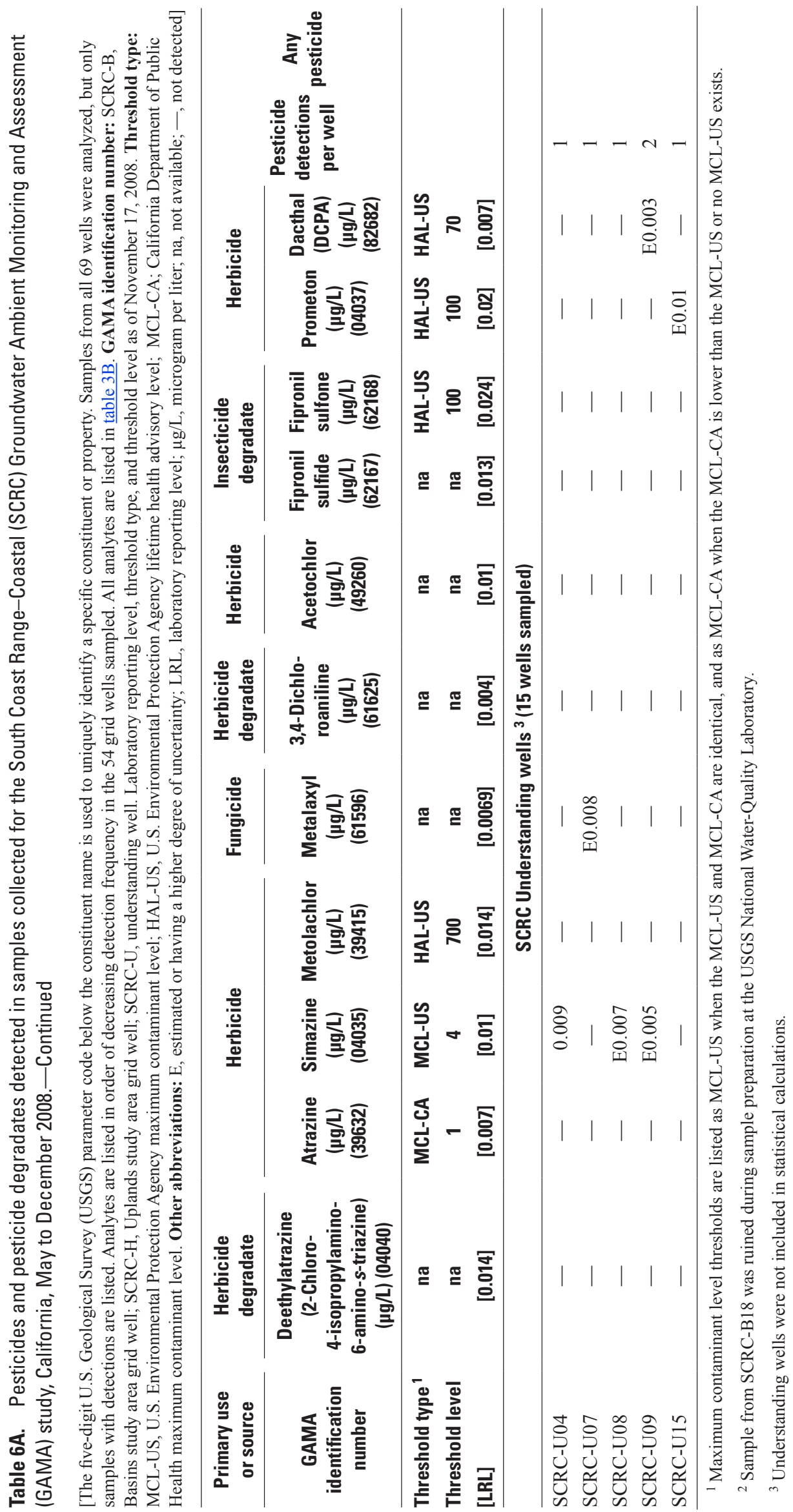


Table 6B. Polar pesticides and metabolites detected in samples collected for the South Coast Range-Coastal (SCRC) Groundwater Ambient Monitoring and Assessment (GAMA) study, California, May to December 2008.

[The five-digit U.S. Geological Survey (USGS) parameter code below the constituent name is used to uniquely identify a specific constituent or property. Samples from 69 wells were analyzed, but only samples with detections are listed. Analytes are listed in order of decreasing detection frequency in the grid wells sampled. All analytes are listed in table 3C. GAMA identification number: SCRC-B, Basins study area grid well; SCRC-U, understanding well. Laboratory reporting level, threshold type, and threshold level as of November 17, 2008. Threshold type: HAL-US, U.S. Environmental Protection Agency lifetime health advisory level. Other abbreviations: LRL, laboratory reporting level; $\mu \mathrm{g} / \mathrm{L}$, microgram per liter; na, not available; E, estimated or having a higher degree of uncertainty; - , not detected.]

\begin{tabular}{|c|c|c|c|c|c|c|}
\hline Primary use or source & Herbicide & Metabolite & & & \multirow[b]{2}{*}{$\begin{array}{c}\text { Pesticide } \\
\text { detections } \\
\text { per well }\end{array}$} & \multirow[b]{2}{*}{$\begin{array}{c}\text { Any } \\
\text { pesticide }\end{array}$} \\
\hline $\begin{array}{c}\text { GAMA } \\
\text { identification } \\
\text { number }\end{array}$ & $\begin{array}{c}\text { Diuron } \\
\text { ( } \mu \mathrm{g} / \mathrm{L}) \\
(49300)\end{array}$ & $\begin{array}{c}\text { 3-(4-Chloro- } \\
\text { phenyl)-1- } \\
\text { methyl urea } \\
(\mu \mathrm{g} / \mathrm{L}) \\
(61692)\end{array}$ & $\begin{array}{c}\text { Bromacil } \\
(\mu \mathrm{g} / \mathrm{L}) \\
(04029)\end{array}$ & $\begin{array}{c}\text { Fenuron } \\
\text { ( } \mu \mathrm{g} / \mathrm{L}) \\
(49297)\end{array}$ & & \\
\hline$[\mathbf{L R L}]$ & {$[0.04]$} & {$[0.06]$} & {$[0.02]$} & {$[0.06]$} & & \\
\hline \multicolumn{7}{|c|}{ SCRC Grid wells ( 54 wells sampled) ${ }^{1}$} \\
\hline SCRC-B05 & E0.02 & - & - & - & 1 & \\
\hline SCRC-B27 & E0.01 & - & 0.08 & - & 2 & \\
\hline Total Detections & & & & & & 4 \\
\hline \multicolumn{7}{|c|}{ SCRC Understanding wells ${ }^{2}$ ( 15 wells sampled) } \\
\hline SCRC-U12 & - & E0.02 & - & 0.14 & 2 & \\
\hline
\end{tabular}

\footnotetext{
${ }^{1}$ Sample from SCRC-B09 was ruined during sample preparation at the USGS National Water-Quality Laboratory.

${ }^{2}$ Understanding wells were not included in statistical calculations.
} 
Table 7. Perchlorate detected in the samples collected for the South Coast Range-Coastal (SCRC) Groundwater Ambient Monitoring and Assessment (GAMA) study, California, May to December 2008.

[The five-digit U.S. Geological Survey (USGS) parameter code below the constituent name is used to uniquely identify a specific constituent or property. Information about the analyte given in table 3E. Samples from all 70 wells were analyzed for perchlorate, but only samples with detections are listed. GAMA identification number: SCRC-B, Basins study area grid well; SCRC-H, Uplands study area grid well; SCRC-U, understanding well. Minimum reporting level, threshold type, and threshold level as of November 17, 2008. Threshold type: MCL-CA, California Department of Public Health maximum contaminant level. Other abbreviations: MRL, method reporting level; $\mu \mathrm{g} / \mathrm{L}$, micrograms per liter]

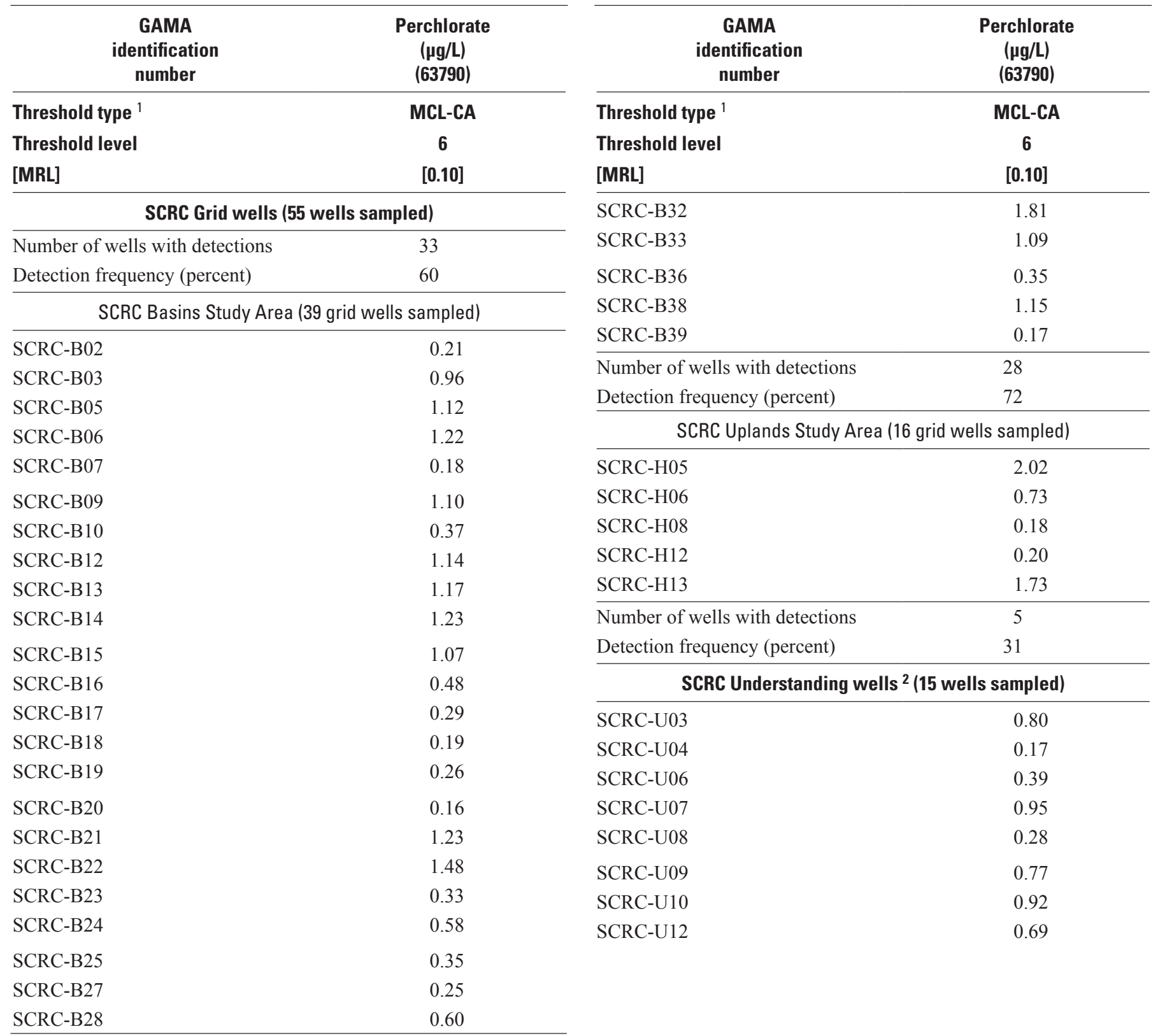

\footnotetext{
${ }^{1}$ Maximum contaminant level thresholds are listed as MCL-US when the MCL-US and MCL-CA are identical, and as MCL-CA when the MCL-CA is lower than the MCL-US or no MCL-US exists.

${ }^{2}$ Understanding wells were not included in statistical calculations.
} 


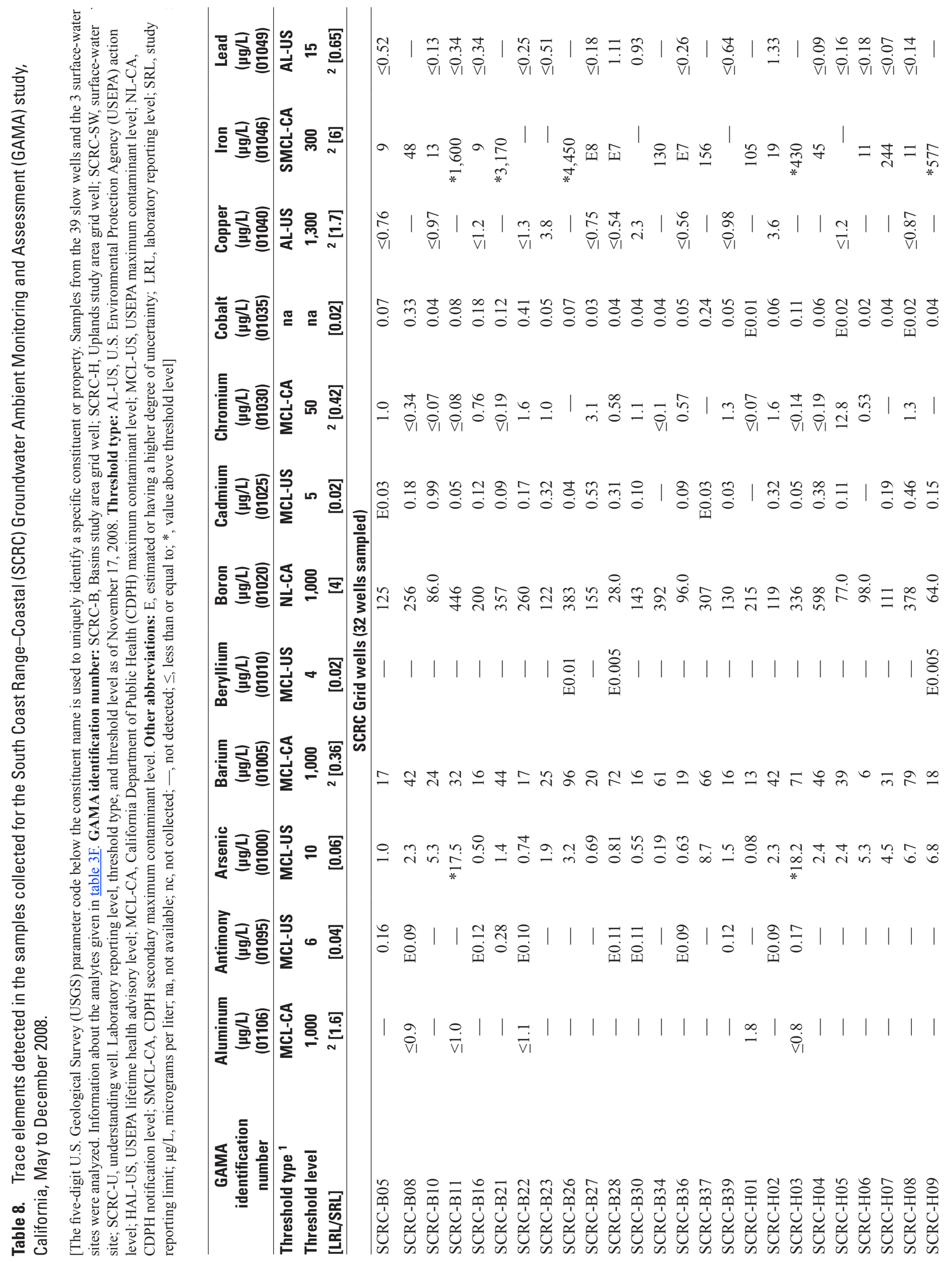




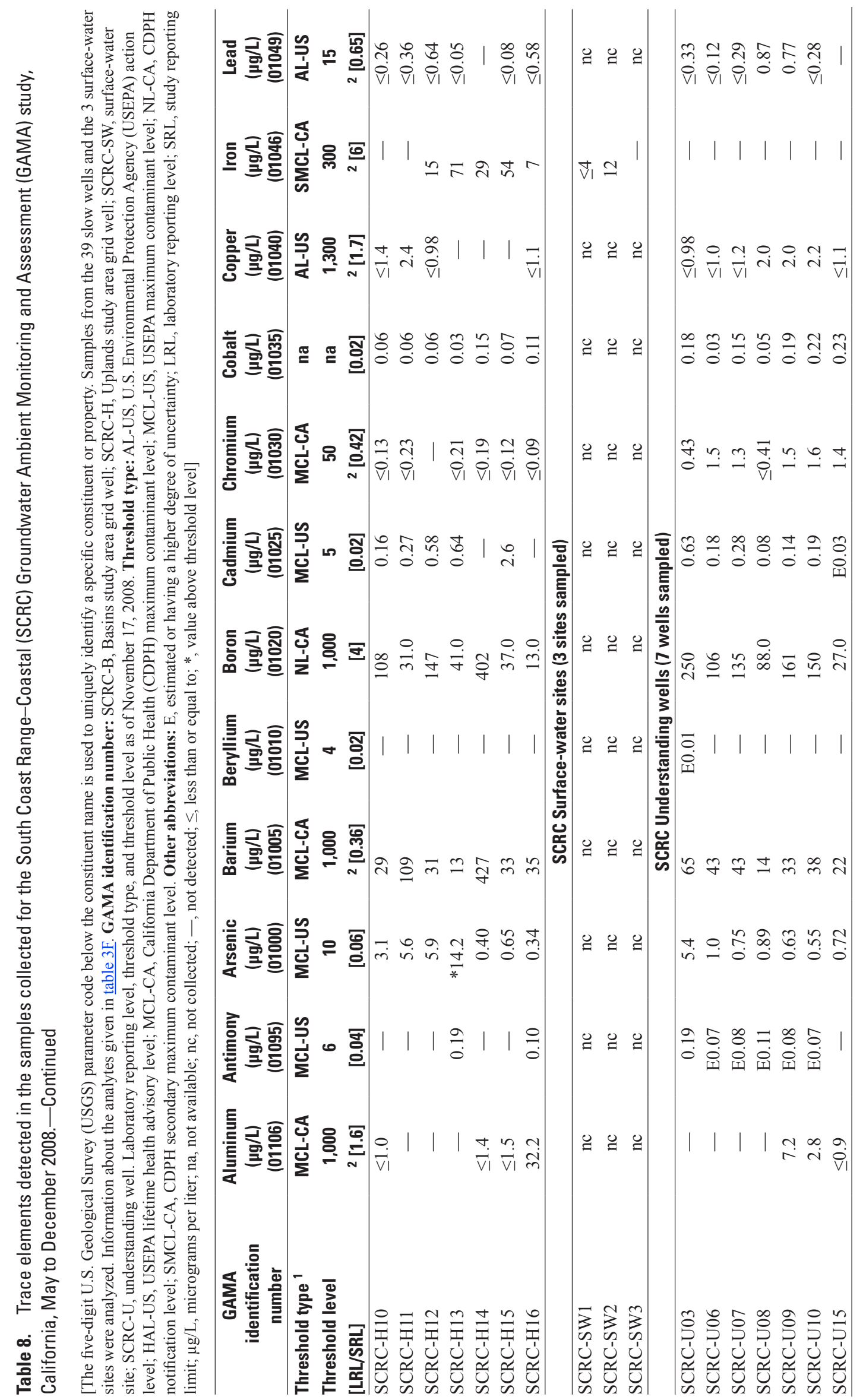




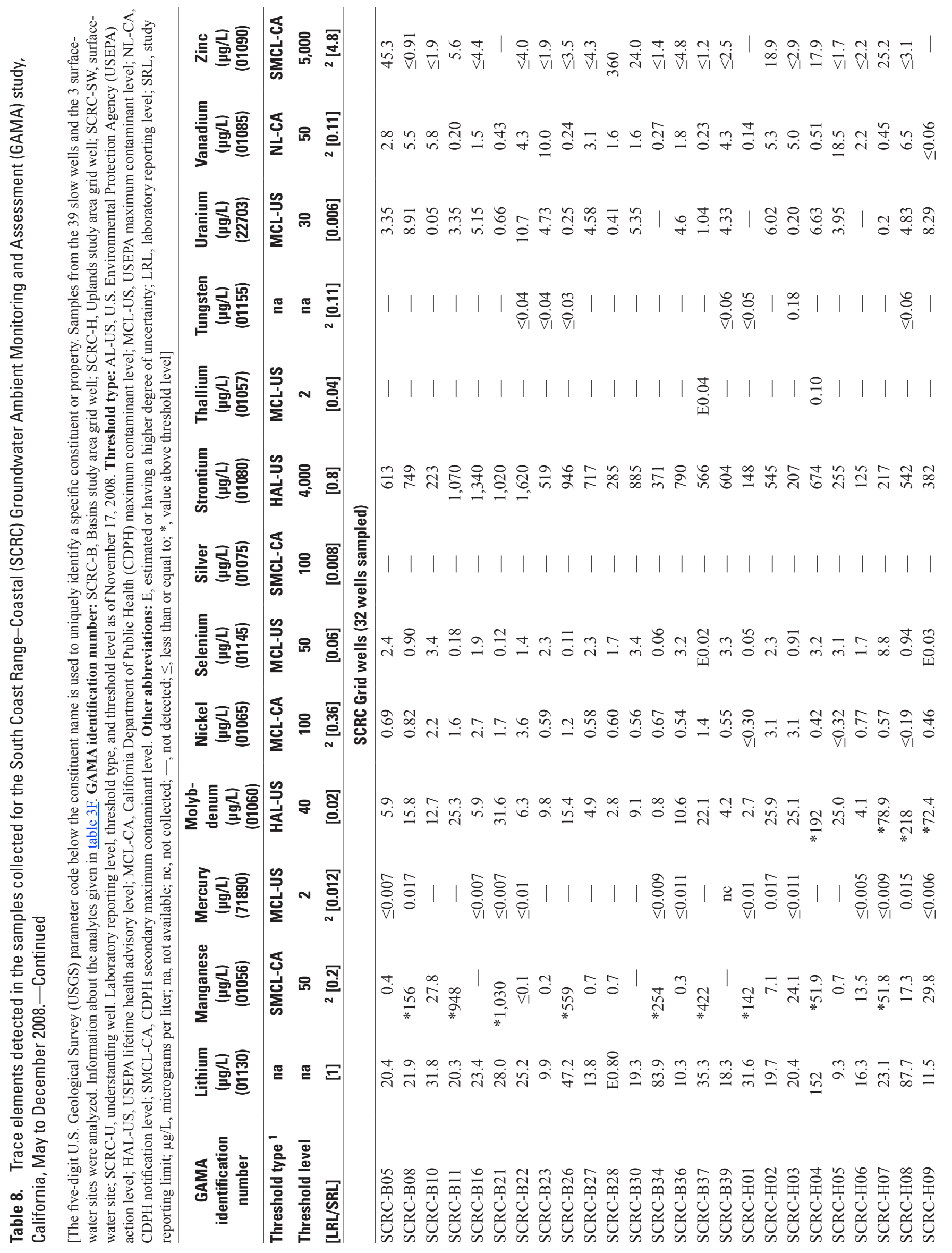




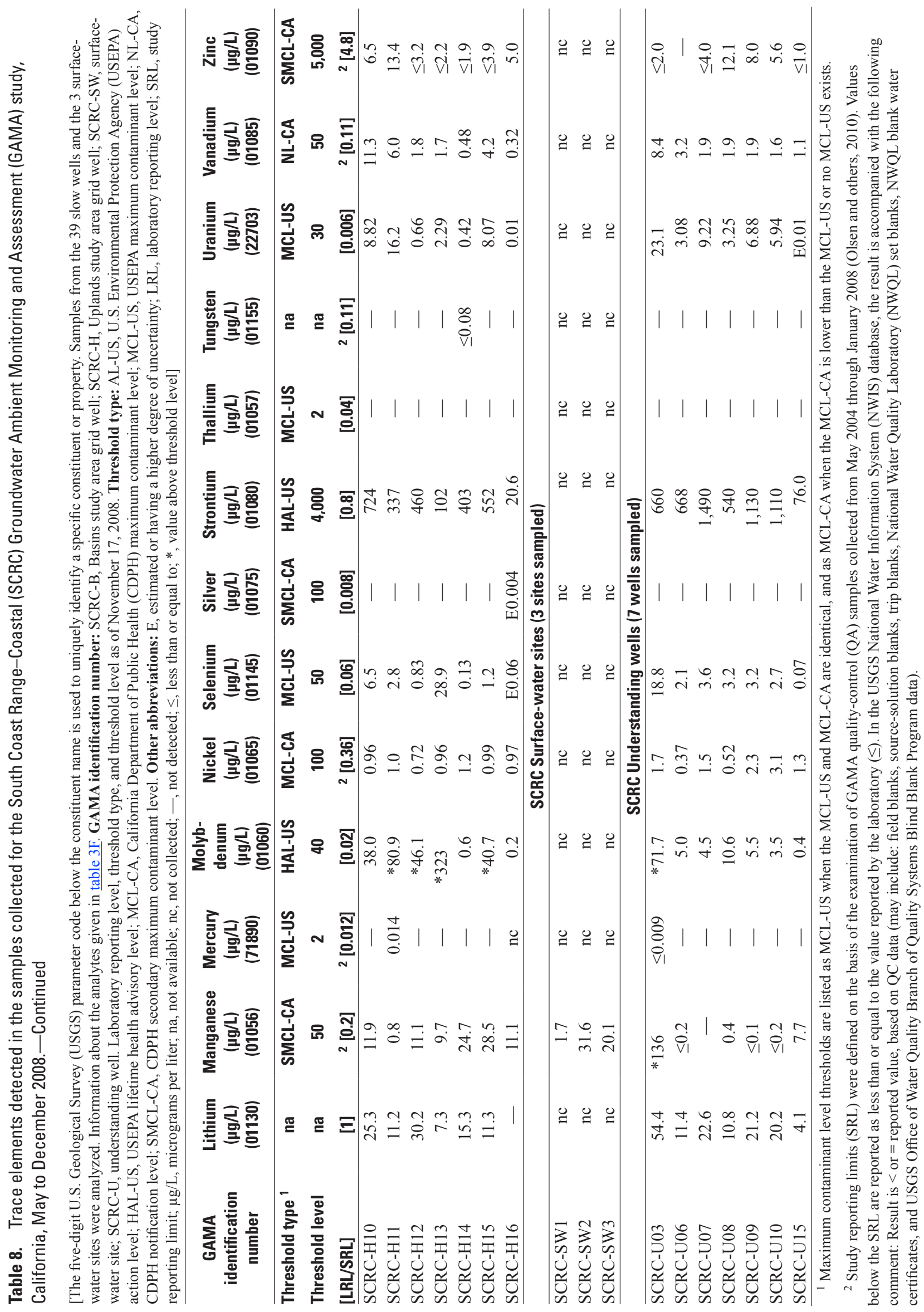




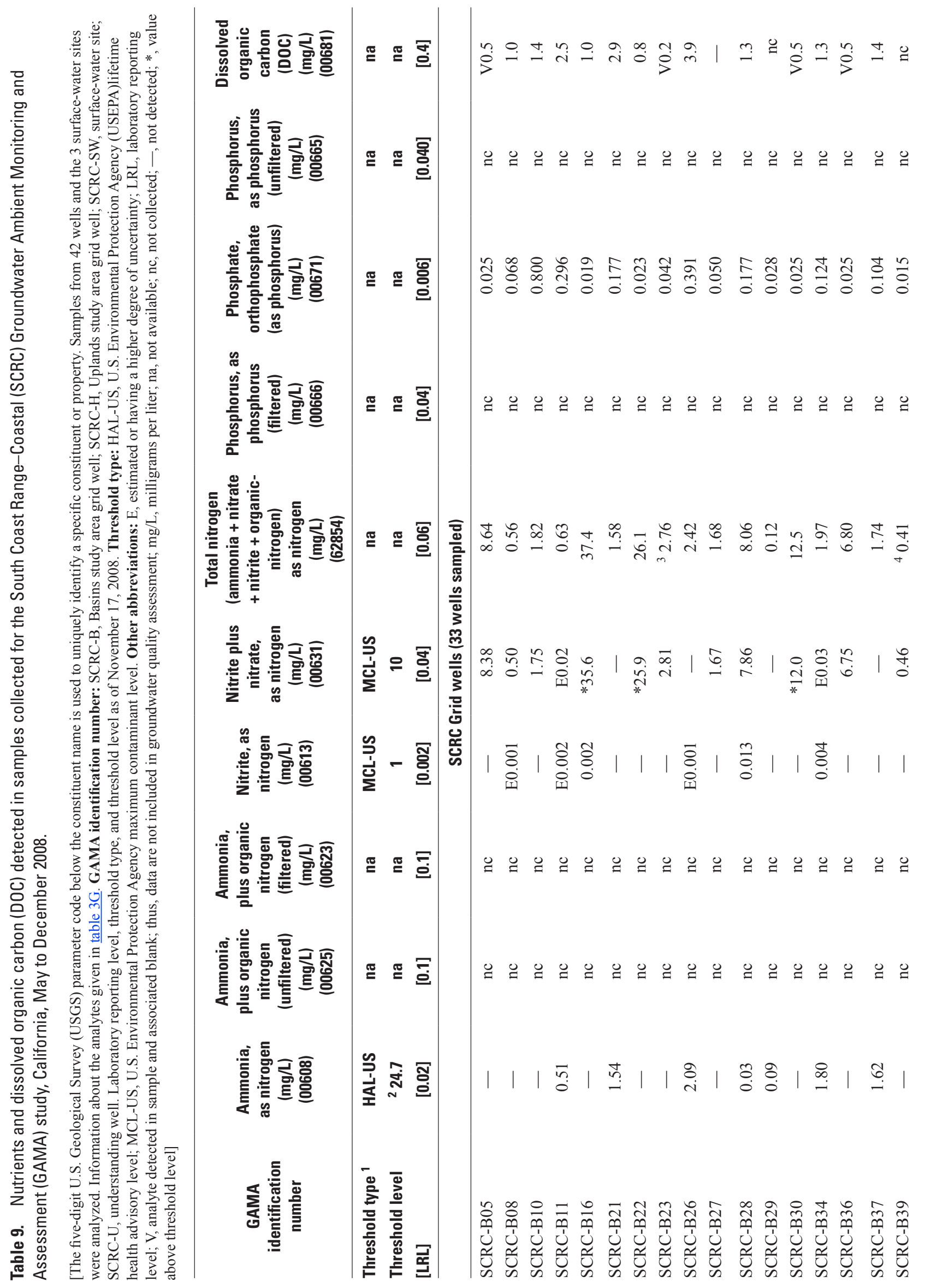




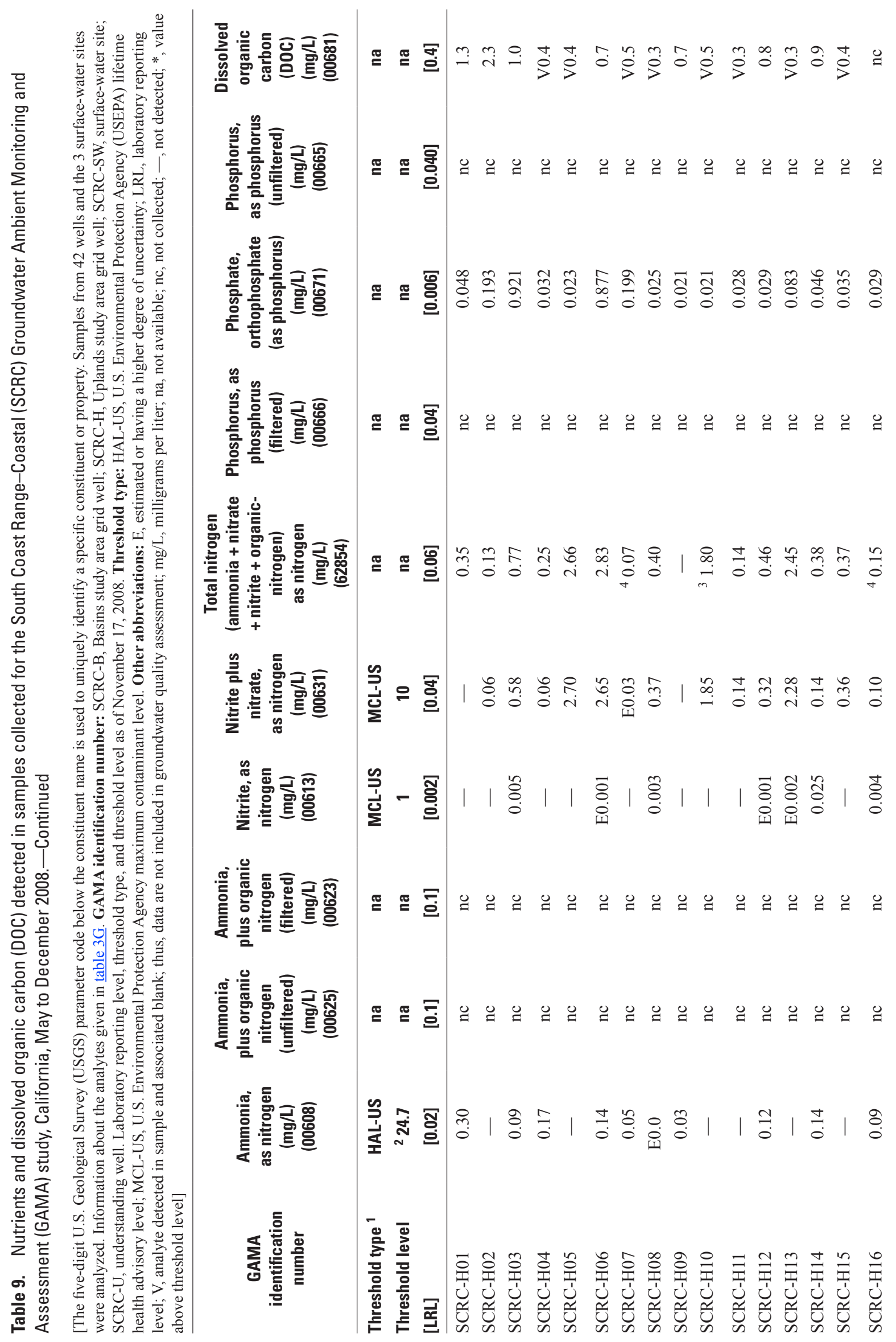




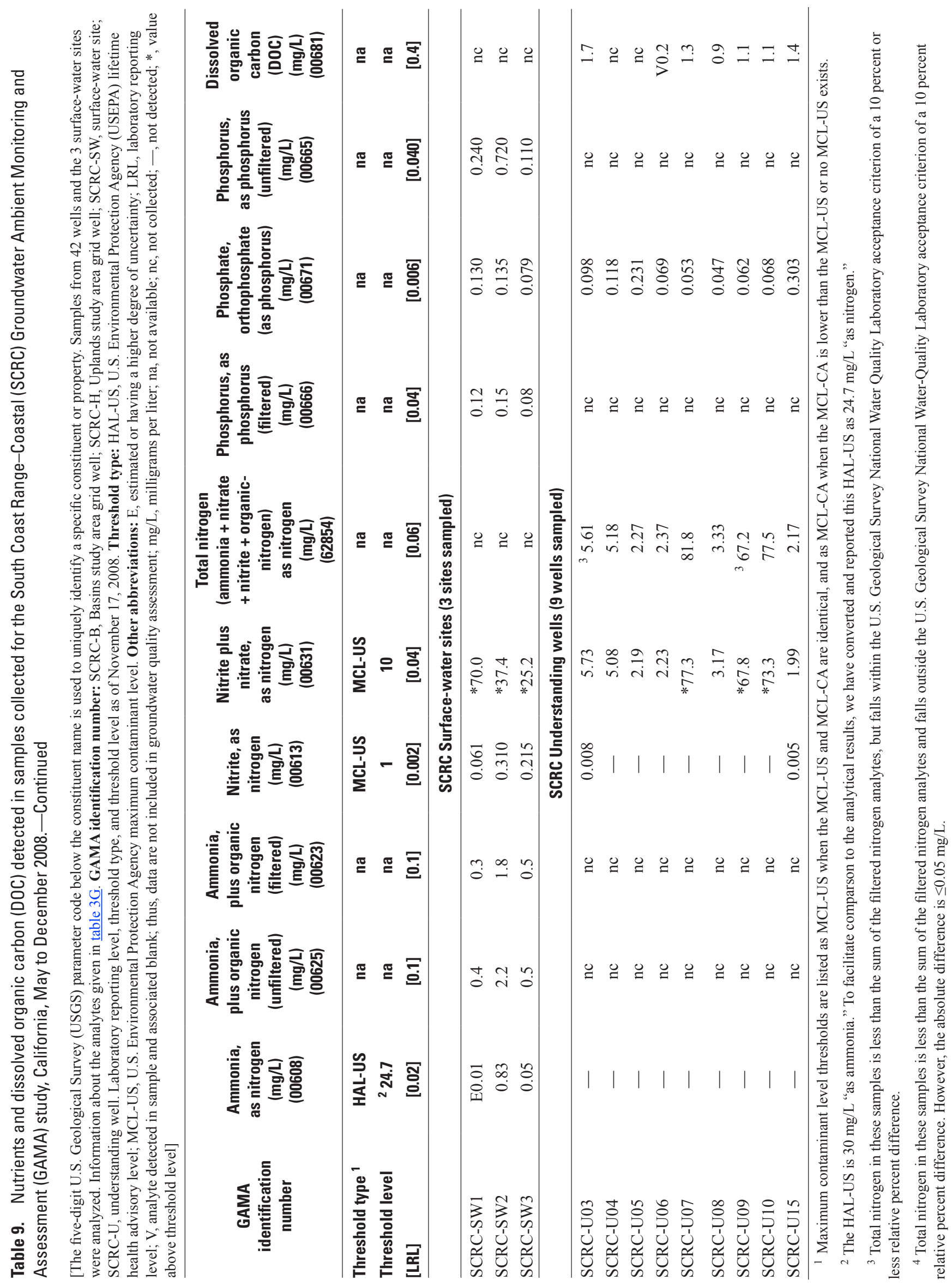


Tables $\quad 67$

可

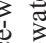

总要量

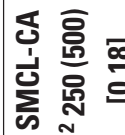

름 흘

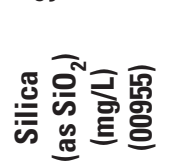

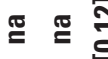

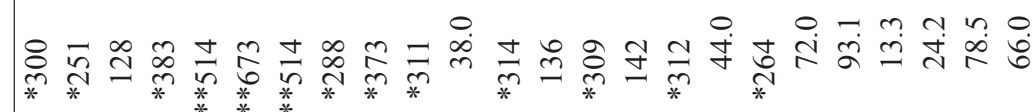

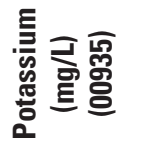

$\cong \cong$

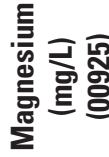

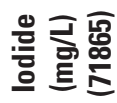

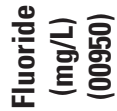

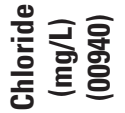

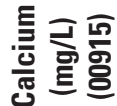

$\cong$ ฐ

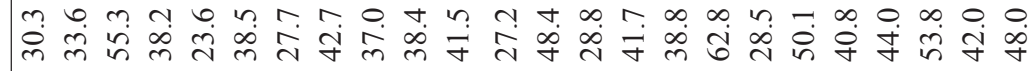
(

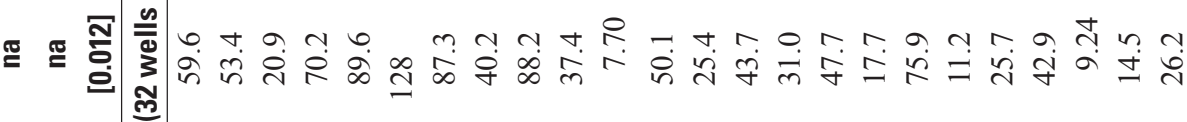

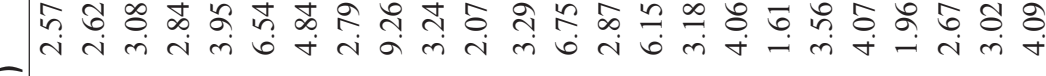
\%

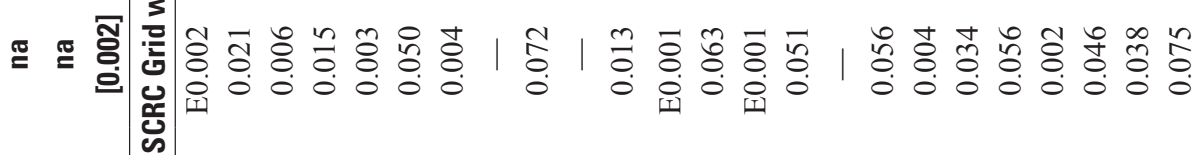

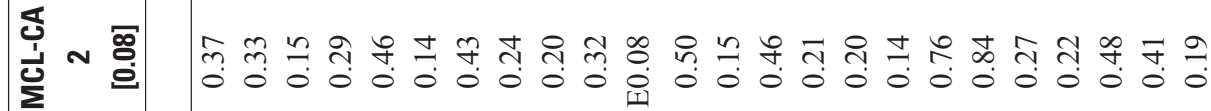
造产

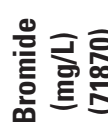

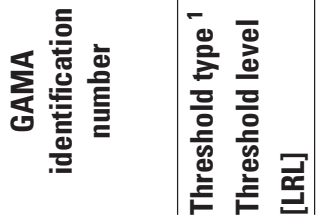

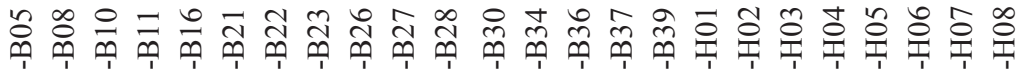

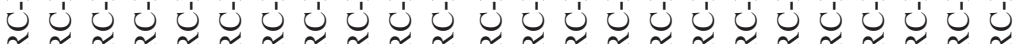

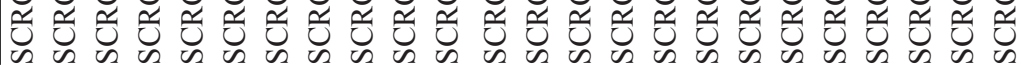




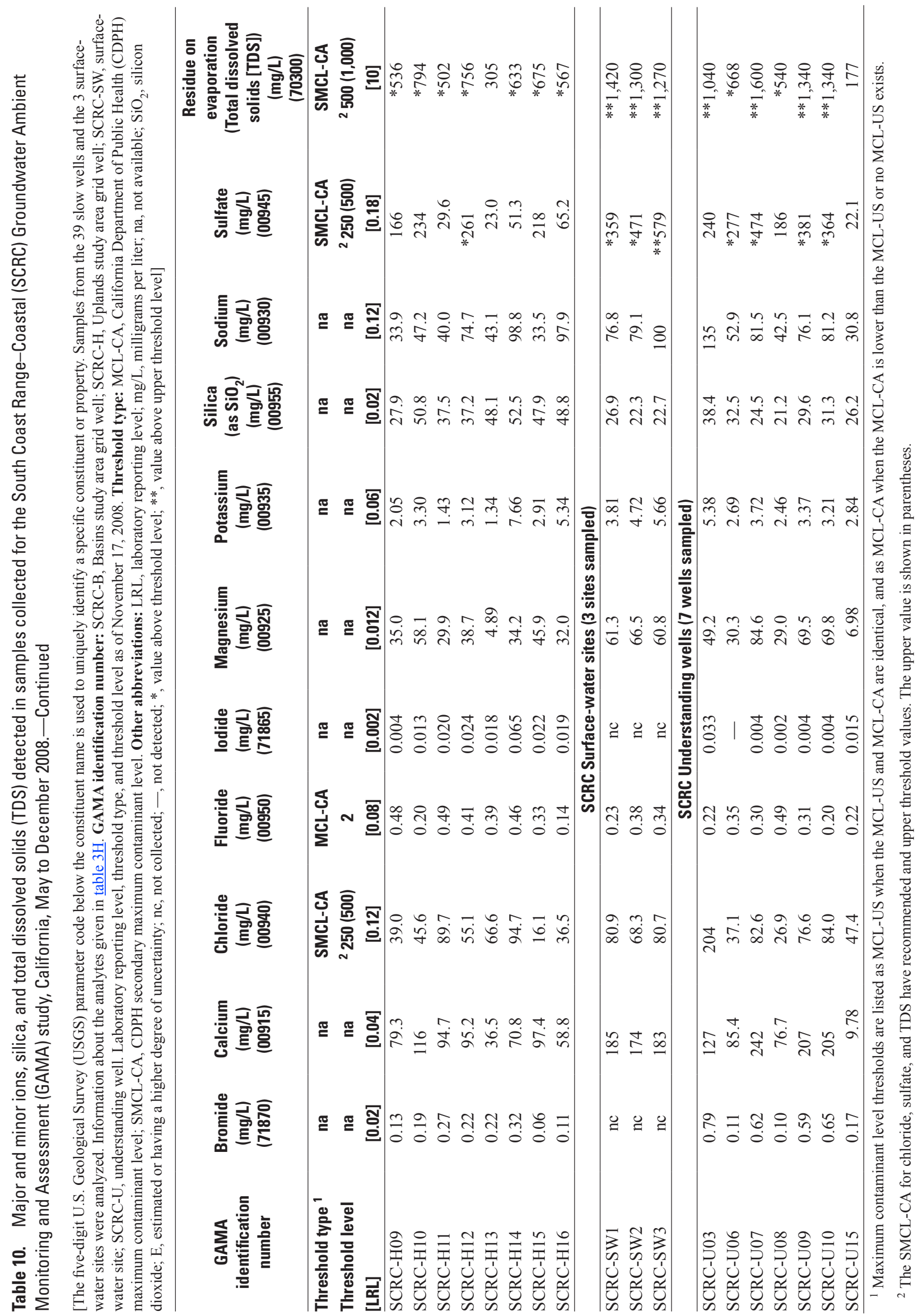


Table 11. Species of inorganic arsenic and iron detected in samples collected for the South Coast Range-Coastal (SCRC) Groundwater Ambient Monitoring and Assessment (GAMA) study, California, May to December 2008.

[Data in this table analyzed at the U.S. Geological Survey (USGS) Trace Metals Laboratory using research methods and are not stored in the USGS National Water Information System database. Information about the analytes given in table 3I. Samples from the 39 slow wells were analyzed, but only samples with at least one detection are listed. GAMA identification number: SCRC-B, Basins study area grid well; SCRC-H, Uplands study area grid well; SCRC-U, understanding well. Method detection limit, threshold type, and threshold level as of November 17, 2008. Threshold type: MCL-US, U.S. Environmental Protection Agency maximum contaminant level; SMCL-CA, California Department of Public Health secondary maximum contaminant level. Other abbreviations: MDL, method detection limit; na, not available; $\mu \mathrm{g} / \mathrm{L}$, micrograms per liter; —, not detected; *, value above threshold level]

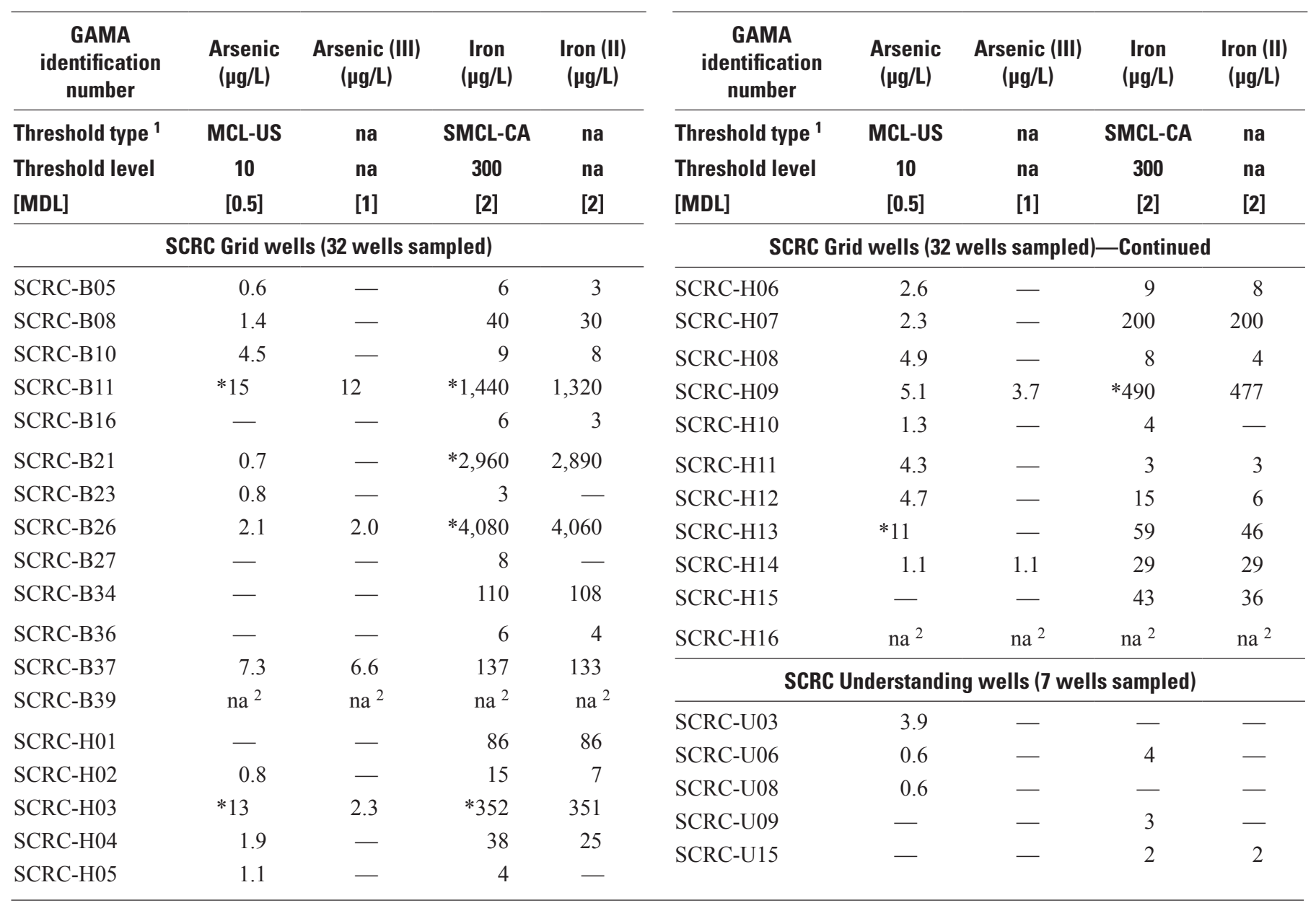

\footnotetext{
${ }^{1}$ Maximum contaminant level thresholds are listed as MCL-US when the MCL-US and MCL-CA are identical, and as MCL-CA when the MCL-CA is lower than the MCL-US or no MCL-US exists.

${ }^{2}$ Analyses at the USGS Trace Metals Laboratory were not completed in time for inclusion in this report; complete results will be presented in a subsequent publication.
} 
Table 12. Results for analyses of stable isotope ratios, tritium activity, and carbon-14 abundance detected in samples collected for the Southern Coast Range-Coastal (SCRC) Groundwater Ambient Monitoring and Assessment (GAMA) study, California, May to December 2008.

[The five-digit U.S.Geological Survey (USGS) parameter code below the constituent name is used to uniquely identify a specific constituent or property. Information about the analytes given in table 3J. Samples from all 70 wells and the 3 surface-water sites were analyzed for stable isotopes of hydrogen and oxygen in water. Samples from all 70 wells were analyzed for tritium activities. Samples from the 12 special study wells and the 3 surface-water sites were analyzed for stable isotopes of nitrogen in dissolved nitrate. Samples from the 39 slow wells were analyzed for stable isotopes of carbon dissolved inorganic carbon and carbon-14 abundance. Stable isotope ratios are reported in the standard delta notation $(\delta)$, the ratio of a heavier isotope to more common lighter isotope of that element, relative to a standard reference material. GAMA identification number: SCRC-B, Basins study area grid well; SCRC-H, Uplands study area grid well; SCRC-SW, surface-water site; SCRC-U, understanding well. Threshold type and threshold level as of November 17, 2008. Threshold type: MCL-CA, California Department of Public Health maximum contaminant level. Other abbreviations: H, hydrogen; O, oxygen; N, nitrogen; C, carbon; pCi/L, picocuries per liter; na, not available; nc, not collected; - , not detected]

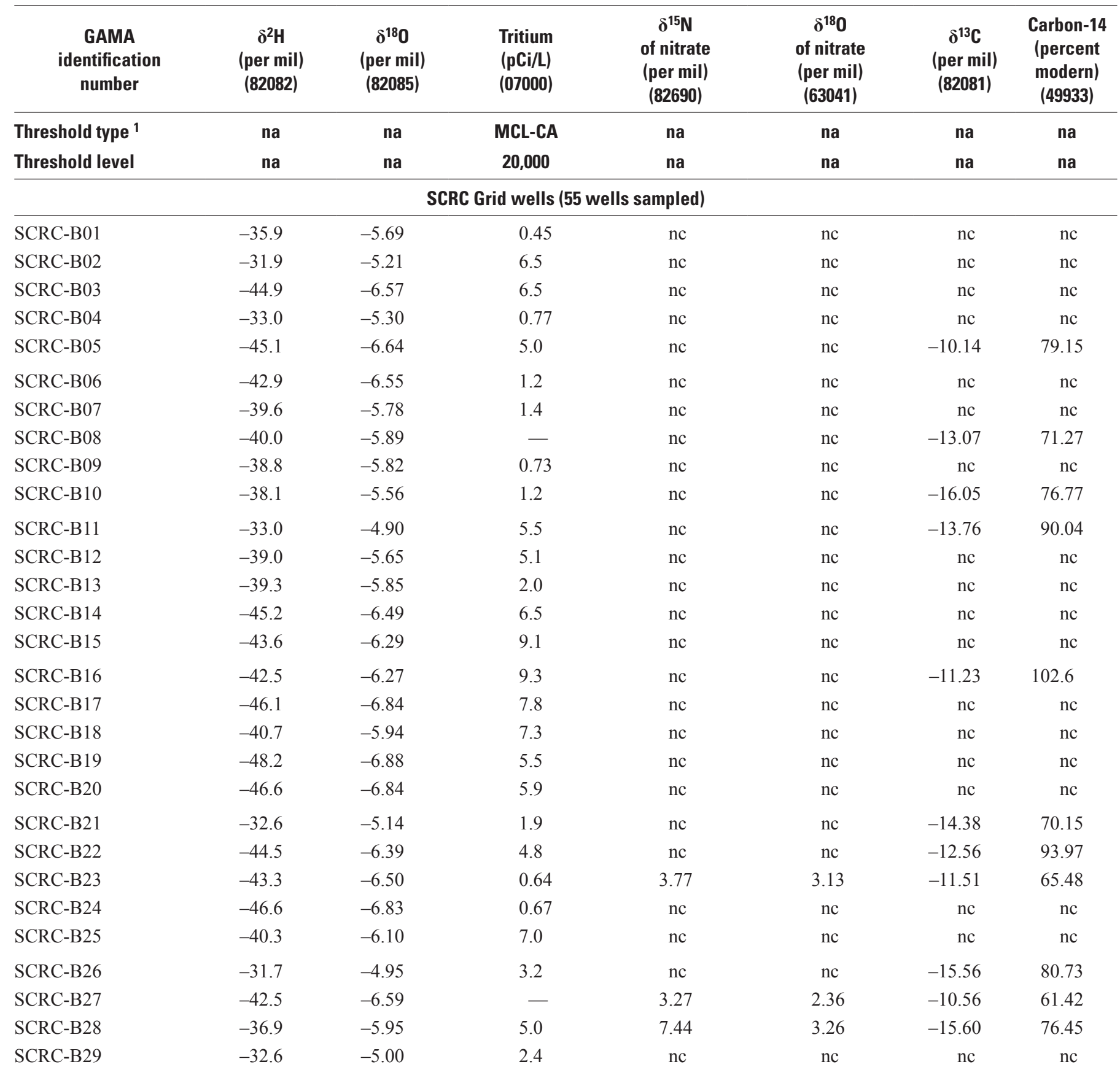


Table 12. Results for analyses of stable isotope ratios, tritium activity, and carbon-14 abundance detected in samples collected for hern Coast RangeSCRC) Groundwater Ambient Monitoring and Assessment (GAMA) study, California, May to December 2008. Continued

[The five-digit U.S.Geological Survey (USGS) parameter code below the constituent name is used to uniquely identify a specific constituent or property. Information about the analytes given in table 3J. Samples from all 70 wells and the 3 surface-water sites were analyzed for stable isotopes of hydrogen and oxygen in water. Samples from all 70 wells were analyzed for tritium activities. Samples from the 12 special study wells and the 3 surface-water sites were analyzed for stable isotopes of nitrogen in dissolved nitrate. Samples from the 39 slow wells were analyzed for stable isotopes of carbon dissolved inorganic carbon and carbon-14 abundance. Stable isotope ratios are reported in the standard delta notation $(\delta)$, the ratio of a heavier isotope to more common lighter isotope of that element, relative to a standard reference material. GAMA identification number: SCRC-B, Basins study area grid well; SCRC-H, Uplands study area grid well; SCRC-SW, surface-water site; SCRC-U, understanding well. Threshold type and threshold level as of November 17, 2008. Threshold type: MCL-CA, California Department of Public Health maximum contaminant level. Other abbreviations: H, hydrogen; O, oxygen; N, nitrogen; C, carbon; pCi/L, picocuries per liter; na, not available; nc, not collected; - , not detected]

\begin{tabular}{|c|c|c|c|c|c|c|c|}
\hline $\begin{array}{c}\text { GAMA } \\
\text { identification } \\
\text { number }\end{array}$ & $\begin{array}{c}\delta^{2} \mathrm{H} \\
\text { (per mil) } \\
(82082)\end{array}$ & $\begin{array}{c}\delta^{18} 0 \\
\text { (per mil) } \\
(82085)\end{array}$ & $\begin{array}{l}\text { Tritium } \\
\text { (pCi/L) } \\
(07000)\end{array}$ & $\begin{array}{c}\delta^{15} \mathrm{~N} \\
\text { of nitrate } \\
\text { (per mil) } \\
(82690)\end{array}$ & $\begin{array}{c}\delta^{18} 0 \\
\text { of nitrate } \\
\text { (per mil) } \\
(63041)\end{array}$ & $\begin{array}{c}\delta^{13} \mathrm{C} \\
\text { (per mil) } \\
(\mathbf{8 2 0 8 1})\end{array}$ & $\begin{array}{c}\text { Carbon-14 } \\
\text { (percent } \\
\text { modern) } \\
\text { (49933) }\end{array}$ \\
\hline Threshold type ${ }^{1}$ & na & na & MCL-CA & na & na & na & na \\
\hline Threshold level & na & na & 20,000 & na & na & na & na \\
\hline SCRC-B30 & -43.1 & -6.46 & 7.2 & 3.88 & 4.57 & -11.97 & 93.67 \\
\hline SCRC-B32 & -40.0 & .91 & 3.6 & $\mathrm{nc}$ & $\mathrm{nc}$ & $\mathrm{nc}$ & $\mathrm{nc}$ \\
\hline SCRC-B33 & -36.8 & -5.72 & - & nc & $\mathrm{nc}$ & $\mathrm{nc}$ & $\mathrm{nc}$ \\
\hline SCRC-B34 & -36.1 & -5.87 & - & nc & $\mathrm{nc}$ & -11.11 & 15.55 \\
\hline SCRC-B35 & -34.1 & -4.92 & 3.0 & $\mathrm{nc}$ & $\mathrm{nc}$ & $\mathrm{nc}$ & $\mathrm{nc}$ \\
\hline SCRC-B39 & -49.1 & -7.13 & - & $\mathrm{nc}$ & $\mathrm{nc}$ & -9.50 & 54.32 \\
\hline SCRC-H01 & -37.0 & -5.91 & - & $\mathrm{nc}$ & $\mathrm{nc}$ & -14.71 & 10.91 \\
\hline SCRC-H02 & -41.3 & -6.64 & 5.8 & nc & $\mathrm{nc}$ & -10.71 & 88.43 \\
\hline SCRC-H03 & -39.6 & -6.11 & 1.0 & nc & $\mathrm{nc}$ & -11.18 & 17.02 \\
\hline SCRC-H04 & -49.7 & -7.26 & - & $\mathrm{nc}$ & $\mathrm{nc}$ & -9.76 & 1.64 \\
\hline SCRC-H05 & -41.3 & -6.00 & 0.35 & $\mathrm{nc}$ & $\mathrm{nc}$ & -12.73 & 26.80 \\
\hline SCRC-H06 & -36.9 & -5.72 & 1.6 & $\mathrm{nc}$ & $\mathrm{nc}$ & -13.72 & 56.05 \\
\hline SCRC-H07 & -39.2 & -5.74 & 1.0 & nc & nc & -12.57 & 48.75 \\
\hline SCRC-H08 & -49.1 & -7.02 & - & nc & $\mathrm{nc}$ & -11.09 & 2.21 \\
\hline SCRC-H15 & -41.0 & -6.03 & - & $\mathrm{nc}$ & $\mathrm{nc}$ & -11.01 & 33.82 \\
\hline SCRC-H16 & -50.6 & -7.37 & 0.73 & $\mathrm{nc}$ & nc & -8.92 & 8.80 \\
\hline \multicolumn{8}{|c|}{ SCRC Surface-water sites (3 sites sampled } \\
\hline SCRC-SW1 & -38.4 & -5.25 & $\mathrm{nc}$ & 4.97 & 5.66 & $\mathrm{nc}$ & nc \\
\hline SCRC-SW2 & -37.2 & -5.47 & $\mathrm{nc}$ & 7.09 & 7.50 & $\mathrm{nc}$ & $\mathrm{nc}$ \\
\hline SCRC-SW3 & -39.4 & -5.91 & $\mathrm{nc}$ & 10.83 & 9.92 & nc & nc \\
\hline
\end{tabular}


Table 12. Results for analyses of stable isotope ratios, tritium activity, and carbon-14 abundance detected in samples collected for hern Coast RangeSCRC) Groundwater Ambient Monitoring and Assessment (GAMA) study, California, May to December 2008.Continued

[The five-digit U.S.Geological Survey (USGS) parameter code below the constituent name is used to uniquely identify a specific constituent or property. Information about the analytes given in table 3J. Samples from all 70 wells and the 3 surface-water sites were analyzed for stable isotopes of hydrogen and oxygen in water. Samples from all 70 wells were analyzed for tritium activities. Samples from the 12 special study wells and the 3 surface-water sites were analyzed for stable isotopes of nitrogen in dissolved nitrate. Samples from the 39 slow wells were analyzed for stable isotopes of carbon dissolved inorganic carbon and carbon-14 abundance. Stable isotope ratios are reported in the standard delta notation $(\delta)$, the ratio of a heavier isotope to more common lighter isotope of that element, relative to a standard reference material. GAMA identification number: SCRC-B, Basins study area grid well; SCRC-H, Uplands study area grid well; SCRC-SW, surface-water site; SCRC-U, understanding well. Threshold type and threshold level as of November 17, 2008. Threshold type: MCL-CA, California Department of Public Health maximum contaminant level. Other abbreviations: H, hydrogen; O, oxygen; N, nitrogen; C, carbon; pCi/L, picocuries per liter; na, not available; nc, not collected; - , not detected]

\begin{tabular}{|c|c|c|c|c|c|c|c|}
\hline $\begin{array}{c}\text { GAMA } \\
\text { identification } \\
\text { number }\end{array}$ & $\begin{array}{c}\delta^{2} \mathrm{H} \\
\text { (per mil) } \\
(\mathbf{8 2 0 8 2})\end{array}$ & $\begin{array}{c}\delta^{18} 0 \\
\text { (per mil) } \\
(82085)\end{array}$ & $\begin{array}{l}\text { Tritium } \\
\text { (pCi/L) } \\
\text { (07000) }\end{array}$ & $\begin{array}{c}\delta^{15} \mathrm{~N} \\
\text { of nitrate } \\
\text { (per mil) } \\
(82690)\end{array}$ & $\begin{array}{c}\delta^{18} 0 \\
\text { of nitrate } \\
\text { (per mil) } \\
(63041)\end{array}$ & $\begin{array}{c}\delta^{13} \mathrm{C} \\
\text { (per mil) } \\
(82081)\end{array}$ & $\begin{array}{c}\text { Carbon-14 } \\
\text { (percent } \\
\text { modern) } \\
\text { (49933) }\end{array}$ \\
\hline Threshold type 1 & na & na & MCL-CA & na & na & na & na \\
\hline Threshold level & na & na & 20,000 & na & na & na & na \\
\hline \multicolumn{8}{|c|}{ SCRC Understanding wells ( 15 wells sampled) } \\
\hline SCRC-U02 & -34.8 & -5.23 & 4.2 & nc & $\mathrm{nc}$ & nc & nc \\
\hline SCRC-U03 & -33.8 & -5.37 & 1.2 & $\mathrm{nc}$ & nc & -13.40 & 78.57 \\
\hline SCRC-U04 & -29.2 & -4.51 & 5.2 & 14.61 & 14.79 & $\mathrm{nc}$ & nc \\
\hline SCRC-U05 & -38.3 & -5.84 & 6.5 & 1.15 & 2.11 & $\mathrm{nc}$ & nc \\
\hline SCRC-U09 & -39.3 & -5.94 & 5.1 & 5.04 & 5.51 & -14.82 & 102.4 \\
\hline SCRC-U10 & -37.6 & -5.63 & 4.8 & 4.93 & 5.67 & -15.46 & 101.5 \\
\hline SCRC-U11 & -28.6 & -5.25 & 5.5 & $\mathrm{nc}$ & $\mathrm{nc}$ & $\mathrm{nc}$ & $\mathrm{nc}$ \\
\hline SCRC-U12 & -33.9 & -5.31 & 5.4 & $\mathrm{nc}$ & $\mathrm{nc}$ & $\mathrm{nc}$ & $\mathrm{nc}$ \\
\hline SCRC-U13 & -36.4 & -6.09 & 6.3 & $\mathrm{nc}$ & $\mathrm{nc}$ & $\mathrm{nc}$ & $\mathrm{nc}$ \\
\hline SCRC-U14 & -38.9 & -5.97 & 6.7 & nc & $\mathrm{nc}$ & $\mathrm{nc}$ & $\mathrm{nc}$ \\
\hline SCRC-U15 & -39.8 & -6.18 & 6.5 & $\mathrm{nc}$ & nc & -20.20 & 95.12 \\
\hline
\end{tabular}

\footnotetext{
${ }^{1}$ Maximum contaminant level thresholds are listed as MCL-US when the MCL-US and MCL-CA are identical, and as MCL-CA when the MCL-CA is lower
} than the MCL-US or no MCL-US exists. 
Table 13. Results for analyses of dissolved gases detected in samples collected for the Southern Coast Range-Coastal (SCRC) Groundwater Ambient Monitoring and Assessment (GAMA) study, California, May to December 2008.

[The five-digit U.S. Geological Survey (USGS) parameter code below the constituent name is used to uniquely identify a specific constituent or property. Information about the analytes given in table $3 \mathrm{~K}$. Samples from the 12 special study wells were analyzed for dissolved gases in water. GAMA identification number: SCRC-B, Basins study area grid well; SCRC-U, understanding well. Other abbreviations: $\mu \mathrm{g} / \mathrm{L}$, micrograms per liter; $\mathrm{mg} / \mathrm{L}$, milligrams per liter; na, not available; - , not detected]

\begin{tabular}{|c|c|c|c|c|c|}
\hline $\begin{array}{c}\text { GAMA } \\
\text { identification } \\
\text { number }\end{array}$ & $\begin{array}{c}\text { Carbon } \\
\text { dioxide } \\
(\mathrm{mg} / \mathrm{L}) \\
(00405)\end{array}$ & $\begin{array}{c}\text { Dissolved } \\
\text { oxygen } \\
\text { (mg/L) } \\
(62971)\end{array}$ & $\begin{array}{l}\text { Argon } \\
(\mathrm{mg} / \mathrm{L}) \\
(82043)\end{array}$ & $\begin{array}{c}\text { Dissolved } \\
\text { nitrogen } \\
\text { gas } \\
\text { (mg/L) } \\
(00597)\end{array}$ & $\begin{array}{c}\text { Methane } \\
(\mu \mathrm{g} / \mathrm{L}) \\
(76994)\end{array}$ \\
\hline Threshold type & na & na & na & na & na \\
\hline Threshold level & na & na & na & na & na \\
\hline \multicolumn{6}{|c|}{ SCRC Grid wells (6 wells sampled) } \\
\hline SCRC-B23 & 19.62 & 7.13 & 0.92 & 30.27 & - \\
\hline SCRC-B27 & 17.61 & 4.39 & 0.89 & 29.84 & - \\
\hline SCRC-B28 & 19.51 & 4.40 & 0.68 & 21.78 & - \\
\hline SCRC-B29 & 41.86 & 0.30 & 0.79 & 30.36 & 0.62 \\
\hline SCRC-B30 & 16.34 & 10.26 & 1.07 & 37.23 & - \\
\hline SCRC-B36 & 15.88 & 8.33 & 0.99 & 35.46 & - \\
\hline \multicolumn{6}{|c|}{ SCRC Understanding wells (6 wells sampled) } \\
\hline SCRC-U04 & 67.94 & 4.91 & 0.74 & 23.29 & 3.87 \\
\hline SCRC-U06 & 14.46 & 6.64 & 0.89 & 28.93 & - \\
\hline SCRC-U07 & 27.91 & 14.58 & 1.25 & 51.11 & - \\
\hline SCRC-U08 & 12.09 & 6.23 & 0.91 & 27.96 & - \\
\hline SCRC-U09 & 26.16 & 6.40 & 0.81 & 27.76 & - \\
\hline SCRC-U10 & 26.56 & 5.58 & 0.70 & 23.65 & - \\
\hline
\end{tabular}


Table 14. Gross alpha and gross beta radioactivity detected in samples collected for the South Coast Range-Coastal (SCRC) Groundwater Ambient Monitoring and Assessment (GAMA) study, California, May to December 2008.

[The five-digit U.S. Geological Survey (USGS) parameter code below the constituent name is used to uniquely identify a specific constituent or property. Samples from the 39 slow wells were analyzed. Information about the analytes given in table 3J. The reference nuclide for measurement of gross alpha is thorium-230 and the reference nuclide for measurement of gross beta is cesium-137. Measured values less than the sample-specific critical level (ssL $\mathrm{C}_{\mathrm{C}}$ ) are reported as non-detections (-). GAMA identification number: SCRC-B, Basins study area grid well; SCRC-H, Uplands study area grid well; SCRC-U, understanding well. Threshold type and threshold level as of November 17, 2008. Threshold type: MCL-US, U.S. Environmental Protection Agency maximum contaminant level; MCL-CA; California Department of Public Health maximum contaminant level. Other abbreviations: CSU, 1-sigma combined standard uncertainty; $\mathrm{pCi} / \mathrm{L}$, picocuries per liter; -, not detected; \pm , plus or minus; *, value above threshold level]

\begin{tabular}{|c|c|c|c|c|c|c|c|c|}
\hline \multirow{2}{*}{$\begin{array}{c}\text { GAMA } \\
\begin{array}{c}\text { identification } \\
\text { number }\end{array} \\
\text { Threshold type }^{1}\end{array}$} & \multicolumn{2}{|l|}{$\begin{array}{c}\text { Gross alpha } \\
\text { radioactivity, } \\
\text { 72-hour count } \\
\text { (pCi/L) } \\
(62636)\end{array}$} & \multicolumn{2}{|c|}{$\begin{array}{c}\text { Gross alpha } \\
\text { radioactivity, } \\
\text { 30-day count } \\
\text { (pCi/L) } \\
\text { (62639) }\end{array}$} & \multicolumn{2}{|c|}{$\begin{array}{l}\text { Gross beta } \\
\text { radioactivity, } \\
\text { 72-hour count } \\
\text { (pCi/L) } \\
\text { (62642) }\end{array}$} & \multicolumn{2}{|c|}{$\begin{array}{l}\text { Gross beta } \\
\text { radioactivity, } \\
\text { 30-day count } \\
\text { (pCi/L) } \\
(62645)\end{array}$} \\
\hline & MCL-US & & MCL-US & & MCL-CA & & MCL-CA & \\
\hline \multirow[t]{2}{*}{ Threshold level } & 15 & & 15 & & 50 & & 50 & \\
\hline & Result \pm CSU & $\mathbf{s s L}_{\mathrm{c}}$ & Result \pm CSU & ssL $_{c}$ & Result \pm CSU & $\mathrm{ssL}_{\mathrm{c}}$ & Result \pm CSU & $\mathbf{s s L}_{\mathrm{C}}$ \\
\hline \multicolumn{9}{|c|}{ SCRC Grid wells ( 32 wells sampled) } \\
\hline SCRC-B05 & $4.2 \pm 1.3$ & 1.5 & $4.7 \pm 1.5$ & 1.7 & $3.71 \pm 0.47$ & 0.60 & $3.82 \pm 0.48$ & 0.62 \\
\hline SCRC-B08 & $10.4 \pm 1.9$ & 1.4 & $5.4 \pm 1.6$ & 1.8 & $3.41 \pm 0.45$ & 0.57 & $6.11 \pm 0.57$ & 0.60 \\
\hline SCRC-B10 & $1.96 \pm 0.68$ & 0.68 & - & 1.4 & $2.82 \pm 0.52$ & 0.76 & $3.01 \pm 0.53$ & 0.75 \\
\hline SCRC-B11 & $-^{2}$ & 1.8 & $2.5 \pm 1.5$ & 2.0 & $2.42 \pm 0.71$ & 1.2 & $3.38 \pm 0.77$ & 1.2 \\
\hline SCRC-B16 & $3.1 \pm 1.8$ & 2.5 & - & 2.2 & $3.68 \pm 0.59$ & 0.77 & $4.98 \pm 0.66$ & 0.86 \\
\hline SCRC-B21 & - & 3.9 & - & 3.3 & $7.9 \pm 1.0$ & 1.3 & $8.8 \pm 1.4$ & 2.1 \\
\hline SCRC-B22 & $29.7 \pm 2.6$ & 2.3 & $7.2 \pm 2.2$ & 2.2 & $5.4 \pm 1.0$ & 1.5 & $8.56 \pm 0.93$ & 1.1 \\
\hline SCRC-B23 & $3.45 \pm 0.97$ & 0.89 & $1.75 \pm 0.77$ & 0.84 & $23.15 \pm 0.43$ & 0.56 & $4.04 \pm 0.52$ & 0.68 \\
\hline SCRC-B26 & - & 4.1 & - & 3.1 & $9.2 \pm 1.0$ & 1.2 & $8.4 \pm 1.1$ & 1.4 \\
\hline SCRC-B27 & $2.0 \pm 1.1$ & 1.3 & $4.6 \pm 1.2$ & 1.1 & $3.67 \pm 0.43$ & 0.54 & $4.47 \pm 0.56$ & 0.74 \\
\hline SCRC-B28 & $1.77 \pm 0.58$ & 0.67 & - & 0.92 & $1.86 \pm 0.49$ & 0.77 & $1.8 \pm 0.49$ & 0.71 \\
\hline SCRC-B30 & $4.1 \pm 1.5$ & 1.7 & - & 1.7 & $3.6 \pm 0.49$ & 0.64 & $3.79 \pm 0.46$ & 0.58 \\
\hline SCRC-B34 & $5.6 \pm 1.7$ & 1.8 & - & 1.8 & $8.22 \pm 0.67$ & 0.61 & $6.57 \pm 0.59$ & 0.62 \\
\hline SCRC-B36 & $4.6 \pm 1.4$ & 1.7 & $2.7 \pm 1.1$ & 1.2 & $2.64 \pm 0.37$ & 0.48 & $4.5 \pm 0.56$ & 0.81 \\
\hline SCRC-B37 & $7.8 \pm 2.1$ & 1.9 & - & 2.2 & $6.1 \pm 0.78$ & 0.94 & $6.41 \pm 0.83$ & 1.0 \\
\hline SCRC-B39 & $5.1 \pm 1.4$ & 1.6 & - & 2.4 & $2.93 \pm 0.4$ & 0.52 & $3.97 \pm 0.43$ & 0.52 \\
\hline SCRC-H01 & $5.0 \pm 1.4$ & 1.2 & $4.2 \pm 1.2$ & 0.96 & $4.35 \pm 0.84$ & 1.2 & $3.3 \pm 1.3$ & 1.9 \\
\hline SCRC-H02 & $4.4 \pm 1.2$ & 1.1 & $3.0 \pm 1.2$ & 1.5 & $2.76 \pm 0.41$ & 0.54 & $5.17 \pm 0.5$ & 0.56 \\
\hline SCRC-H03 & $2.68 \pm 0.8$ & 0.86 & - & 1.0 & $5.16 \pm 0.66$ & 0.87 & $3.81 \pm 0.83$ & 1.3 \\
\hline SCRC-H04 & $28.1 \pm 1.9$ & 1.9 & $4.0 \pm 1.4$ & 1.5 & $4.48 \pm 0.54$ & 0.64 & $6.3 \pm 0.61$ & 0.65 \\
\hline SCRC-H05 & $4.83 \pm 0.9$ & 0.6 & $1.76 \pm 0.63$ & 0.71 & $2.39 \pm 0.48$ & 0.68 & $2.78 \pm 0.48$ & 0.68 \\
\hline
\end{tabular}


Table 14. Gross alpha and gross beta radioactivity detected in samples collected for the South Coast Range-Coastal (SCRC) Groundwater Ambient Monitoring and Assessment (GAMA) study, California, May to December 2008.-Continued

[The five-digit U.S. Geological Survey (USGS) parameter code below the constituent name is used to uniquely identify a specific constituent or property. Samples from the 39 slow wells were analyzed. Information about the analytes given in table 3J. The reference nuclide for measurement of gross alpha is thorium-230 and the reference nuclide for measurement of gross beta is cesium-137. Measured values less than the sample-specific critical level $\left(\mathrm{ssL}_{\mathrm{C}}\right)$ are reported as non-detections (-). GAMA identification number: SCRC-B, Basins study area grid well; SCRC-H, Uplands study area grid well; SCRC-U, understanding well. Threshold type and threshold level as of November 17, 2008. Threshold type: MCL-US, U.S. Environmental Protection Agency maximum contaminant level; MCL-CA; California Department of Public Health maximum contaminant level. Other abbreviations: CSU, 1-sigma combined standard uncertainty; $\mathrm{pCi} / \mathrm{L}$, picocuries per liter; -, not detected; \pm , plus or minus; *, value above threshold level]s

\begin{tabular}{|c|c|c|c|c|c|c|c|c|}
\hline \multirow{4}{*}{$\begin{array}{c}\text { GAMA } \\
\begin{array}{c}\text { identification } \\
\text { number }\end{array} \\
\text { Threshold type }^{1} \\
\text { Threshold level }\end{array}$} & \multicolumn{2}{|c|}{$\begin{array}{c}\text { Gross alpha } \\
\text { radioactivity, } \\
\text { 72-hour count } \\
\text { (pCi/L) } \\
(62636)\end{array}$} & \multicolumn{2}{|c|}{$\begin{array}{c}\text { Gross alpha } \\
\text { radioactivity, } \\
\text { 30-day count } \\
\text { (pCi/L) } \\
\text { (62639) }\end{array}$} & \multicolumn{2}{|c|}{$\begin{array}{l}\text { Gross beta } \\
\text { radioactivity, } \\
\text { 72-hour count } \\
\text { (pCi/L) } \\
(62642)\end{array}$} & \multicolumn{2}{|c|}{$\begin{array}{c}\text { Gross beta } \\
\text { radioactivity, } \\
\text { 30-day count } \\
\text { (pCi/L) } \\
\text { (62645) }\end{array}$} \\
\hline & MCL-US & \multicolumn{3}{|c|}{ MCL-US } & \multirow{2}{*}{\multicolumn{2}{|c|}{$\begin{array}{c}\text { MCL-CA } \\
50\end{array}$}} & \multirow{2}{*}{\multicolumn{2}{|c|}{$\begin{array}{c}\text { MCL-CA } \\
50\end{array}$}} \\
\hline & 15 & & 15 & & & & & \\
\hline & Result \pm CSU & $\operatorname{ssL}_{\mathrm{c}}$ & Result \pm CSU & ss $_{\mathrm{c}}$ & Result \pm CSU & ssL $_{c}$ & Result \pm CSU & ssL $_{c}$ \\
\hline SCRC-H06 & $1.36 \pm 0.62$ & 0.67 & - & 1.1 & $2.49 \pm 0.5$ & 0.72 & - & 1.6 \\
\hline SCRC-H07 & $6.9 \pm 1.4$ & 0.94 & $3.3 \pm 1.2$ & 1.1 & $3.05 \pm 0.72$ & 1.0 & $2.99 \pm 0.87$ & 1.3 \\
\hline SCRC-H08 & $9.1 \pm 1.8$ & 1.3 & $3.9 \pm 1.1$ & 1.1 & $3.56 \pm 0.43$ & 0.54 & $4.91 \pm 0.47$ & 0.49 \\
\hline SCRC-H09 & $8.4 \pm 1.4$ & 0.98 & $4.6 \pm 1.3$ & 0.98 & $3.45 \pm 0.87$ & 1.4 & $5.12 \pm 0.9$ & 1.2 \\
\hline SCRC-H10 & $3.5 \pm 1.5$ & 2.0 & $4.7 \pm 1.5$ & 1.6 & $3.47 \pm 0.82$ & 1.2 & $4.89 \pm 0.61$ & 0.8 \\
\hline SCRC-H11 & $14.1 \pm 2.3$ & 1.6 & $11.1 \pm 1.8$ & 1.0 & $1.88 \pm 0.48$ & 0.71 & $6.06 \pm 0.55$ & 0.56 \\
\hline SCRC-H12 & $3.2 \pm 1.1$ & 1.1 & $8.0 \pm 1.7$ & 1.4 & $4.63 \pm 0.46$ & 0.50 & $4.26 \pm 0.55$ & 0.81 \\
\hline SCRC-H13 & - & 0.60 & - & 0.75 & $2.85 \pm 0.43$ & 0.61 & $2.89 \pm 0.47$ & 0.61 \\
\hline SCRC-H14 & $4.0 \pm 1.3$ & 1.5 & $1.8 \pm 1.1$ & 1.5 & $9.45 \pm 0.79$ & 0.78 & $6.3 \pm 0.65$ & 0.78 \\
\hline SCRC-H15 & $6.2 \pm 1.4$ & 1.4 & $4.5 \pm 1.2$ & 1.1 & $3.35 \pm 0.58$ & 0.8 & $4.78 \pm 0.44$ & 0.45 \\
\hline SCRC-H16 & $5.0 \pm 1.2$ & 0.96 & - & 2.7 & ${ }^{2} 5.27 \pm 0.52$ & 0.57 & $6.28 \pm 0.65$ & 0.86 \\
\hline \multicolumn{9}{|c|}{ SCRC Understanding wells (7 wells sampled) } \\
\hline SCRC-U03 & $* 16.8 \pm 2.8$ & 1.5 & $11.5 \pm 2.5$ & 2.2 & $6.39 \pm 0.65$ & 0.74 & $13.5 \pm 1.0$ & 0.81 \\
\hline SCRC-U06 & - & 1.6 & $1.18 \pm 0.81$ & 1.1 & $3.12 \pm 0.82$ & 1.3 & $3.34 \pm 0.82$ & 1.3 \\
\hline SCRC-U07 & $11.2 \pm 3.0$ & 3.0 & $6.2 \pm 2.2$ & 2.5 & $3.4 \pm 0.77$ & 1.1 & $6.8 \pm 1.4$ & 1.9 \\
\hline SCRC-U08 & $4.2 \pm 1.0$ & 0.85 & - & 1.4 & $2.55 \pm 0.62$ & 0.92 & $2.85 \pm 0.96$ & 1.4 \\
\hline SCRC-U09 & $6.8 \pm 2.2$ & 2.5 & $3.2 \pm 1.6$ & 1.9 & $4.66 \pm 0.7$ & 0.92 & $4.66 \pm 0.75$ & 1.1 \\
\hline SCRC-U10 & $4.9 \pm 2.4$ & 3.1 & $4.7 \pm 1.9$ & 2.1 & $2.8 \pm 0.72$ & 1.0 & $4.78 \pm 0.7$ & 0.88 \\
\hline SCRC-U15 & $3.43 \pm 0.7$ & 0.38 & $1.55 \pm 0.86$ & 1.1 & $1.67 \pm 0.36$ & 0.52 & $2.31 \pm 0.61$ & 0.86 \\
\hline
\end{tabular}

${ }^{1}$ Maximum contaminant level thresholds are listed as MCL-US when the MCL-US and MCL-CA are identical, and as MCL-CA when the MCL-CA is lower than the MCL-US or no MCL-US exists.

${ }^{2}$ Counted 4-6 days after collection. 


\section{Appendix}

This appendix includes discussions of the methods used to collect and analyze groundwater and surface-water samples and report the resulting water-quality data. These methods were selected to obtain representative samples of the groundwater from each well and to minimize the potential for contamination of the samples or bias in the data. Procedures used to collect and assess quality-control data, and the results of the quality-control assessments also are discussed.

\section{Sample Collection and Analysis}

Groundwater samples were collected using standard and modified USGS protocols from the USGS NAWQA program (Koterba and others, 1995), the USGS National Field Manual (U.S. Geological Survey, variously dated), and protocols described by Weiss (1968), Shelton and others (2001), McCleskey and others (2003), and Wright and others (2005).

Prior to sampling, each well was pumped continuously to purge at least three casing-volumes of water from the well (Wilde and others, 1999). Wells were sampled using Teflon ${ }^{\circledR}$ tubing with brass and stainless-steel fittings attached to a sampling point on the well discharge pipe as close to the well-head as possible. The sampling point always was located upstream of any well-head treatment system or water storage tank. For the fast schedule, samples were collected at the well head using a foot-long length of Teflon ${ }^{\circledR}$ tubing. For the slow schedule, the samples were either collected in the same manner as the fast schedule or collected inside an enclosed chamber located inside a mobile laboratory and connected to the well head by a 10-50 ft length of the Teflon ${ }^{\circledR}$ tubing (Lane and others, 2003). All fittings and lengths of tubing were cleaned between samples (Wilde, 2004).

For the field measurements, groundwater was pumped through a flow-through chamber fitted with a multi-probe meter that simultaneously measures the field water-quality indicators - dissolved oxygen, temperature, $\mathrm{pH}$, turbidity, and specific conductance. Turbidity was measured in the field with a calibrated turbidity meter. Field measurements were made in accordance with protocols in the USGS National Field Manual (Radtke and others, 2005; Wilde and Radtke, 2005; Lewis, 2006; Wilde, 2006; Wilde and others, 2006). All sensors on the multi-probe meter were calibrated daily. Measured temperature, dissolved oxygen, $\mathrm{pH}$, specific conductance, and turbidity values were recorded at 5-min intervals for at least $30 \mathrm{~min}$, and when these values remained stable for $20 \mathrm{~min}$, samples for laboratory analyses then were collected.

Field measurements and instrument calibrations were recorded by hand on field record sheets and electronically in portable computer field forms (PCFF), a software package designed by the USGS with support from the GAMA Program.
Analytical service requests also were managed by PCFF. Information from PCFF was uploaded directly into NWIS at the end of every week of sample collection.

For analyses requiring filtered water, groundwater was diverted through a disk filter, a baked $0.7-\mu \mathrm{m}$ nominal pore-size glass-fiber filter, or a 0.45 - $\mu$ m pore-size Whatman ${ }^{\circledR}$ vented capsule filter, depending on the protocol for the analysis (Wilde and others, 1999, 2004). Prior to sample collection, polyethylene sample bottles were pre-rinsed two times using deionized water, and then once with sample water before sample collection. Samples requiring acidification were acidified to a $\mathrm{pH}$ of 2 or less with the appropriate acids using ampoules of certified, traceable concentrated acids obtained from the NWQL.

Temperature-sensitive samples were stored on ice prior to, and during daily shipping to the various laboratories. The non-temperature sensitive samples for tritium, dissolved noble gases, and stable isotopes of hydrogen and oxygen in water and of sulfur in dissolved sulfate were shipped monthly, while temperature- or time-sensitive samples for VOCs, pesticides and pesticide degradates, polar pesticides and metabolites, perchlorate, NDMA, 1,2,3-TCP, trace elements, nutrients, DOC, major and minor ions, silica, TDS, gross alpha and gross beta radioactivity, and dissolved gases were shipped daily. The temperature-sensitive samples for stable isotopes of carbon in dissolved inorganic carbon and carbon-14 abundance, nitrogen and oxygen in dissolved nitrate, and arsenic and iron speciation were stored on ice, archived in a laboratory refrigerator and/or freezer, and shipped after results for alkalinity, nitrate, and the metal concentrations were received from the NWQL.

Detailed sampling protocols for individual analyses and groups of analytes are described in Koterba and others (1995), the USGS National Field Manual (Wilde and others, 1999, 2004), and in the references for analytical methods listed in table A1; only brief descriptions are given here. Volatile organic compounds (VOC) samples were collected in $40-\mathrm{mL}$ sample vials that were purged with three vial volumes of sample water before bottom filling to eliminate atmospheric contamination. One to one $(1: 1)$ hydrochloric acid to water $\left(\mathrm{HCl} / \mathrm{H}_{2} \mathrm{O}\right)$ solution was added as a preservative to the VOC samples. Each sample to be analyzed for perchlorate was collected in a $125-\mathrm{mL}$ polystyrene bottle and then filtered in two or three $20-\mathrm{mL}$ aliquots through a $0.20-\mu \mathrm{m}$ pore-size Corning ${ }^{\circledR}$ syringe-tip disk filter into a sterilized $125-\mathrm{mL}$ bottle. Tritium samples were collected by bottom filling one 1-L polyethylene bottle and one 1-L glass bottle with unfiltered groundwater, after first overfilling the bottles with three volumes of water. Samples for analysis of stable isotopes of hydrogen and oxygen in water were collected in a $60-\mathrm{mL}$ clear glass bottle filled with unfiltered water, sealed with a conical cap, and secured with electrical tape to prevent leakage and evaporation. 
Pesticides and pesticide degradates, polar pesticides and metabolites, pharmaceutical compounds, and NDMA samples were collected in 1-L baked amber glass bottles. Pesticide and pharmaceutical samples were filtered through a $0.7-\mu \mathrm{m}$ nominal pore-size glass fiber filter during collection, whereas the NDMA samples were filtered at Weck Laboratories, Inc. prior to analysis. Samples of NDMA were collected in containers treated with $0.05 \mathrm{~g}$ of sodium thiosulfate $\left(\mathrm{Na}_{2} \mathrm{~S}_{2} \mathrm{O}_{3}\right)$.

Groundwater samples for trace elements, major and minor ions, silica, TDS, and field alkalinity analyses required filling one $250-\mathrm{mL}$ polyethylene bottle with untreated groundwater, and one $500-\mathrm{mL}$ and one $250-\mathrm{mL}$ polyethylene bottle with filtered groundwater (Wilde and others, 2004). Filtration was done using a $0.45-\mu \mathrm{m}$ pore-size Whatman ${ }^{\circledR}$ vented capsule filter. The $250-\mathrm{mL}$ filtered sample then was preserved with $7.5-\mathrm{N}$ nitric acid. Mercury samples were collected by filtering groundwater into a $250-\mathrm{mL}$ glass bottle and preserving with 6-N hydrochloric acid. Arsenic and iron speciation samples were filtered into a $250-\mathrm{mL}$ polyethylene bottle that was covered with tape to prevent light exposure and preserved with 6-N hydrochloric acid. Gross alpha and gross beta radiation samples were filtered into a 1-L polyethylene bottle and acidified with nitric acid. The nutrient and stable isotopes of nitrogen and oxygen in dissolved nitrate samples each were filtered into $125-\mathrm{mL}$ brown polyethylene bottles. Stable isotopes of sulfur in dissolved sulfate samples were filtered into two 1-L polyethylene bottles. Stable isotopes of carbon in dissolved inorganic carbon and carbon-14 abundance samples were filtered and bottom filled into $500-\mathrm{mL}$ glass bottles that first were overfilled with three bottle volumes of groundwater. Stable isotopes of carbon in dissolved inorganic carbon and carbon-14 abundance samples had no headspace and were sealed with a conical cap to avoid atmospheric contamination. Samples for field alkalinity titrations were collected by filtering groundwater into $500-\mathrm{mL}$ polyethylene bottles.

DOC and the dissolved gases were collected from the hose bib at the well head, regardless of the sampling schedule (fast, slow, or special study).

DOC was collected using a 50-mL syringe and Acrodisc ${ }^{\circledR}$ $0.45-\mu \mathrm{m}$ disk filter. For each sample, 50 -mL of blank water and $50-\mathrm{mL}$ of groundwater were filtered through the apparatus before filtering $100-\mathrm{mL}$ of groundwater into a $125-\mathrm{mL}$ baked glass bottle (Wilde and others, 2004). Each sample then was preserved immediately by lowering the $\mathrm{pH}$ to 2 with $4.5-\mathrm{N}$ sulfuric acid.

Dissolved gases were collected by bottom filling two $150-\mathrm{mL}$ glass serum bottles that were first overfilled with approximately 5 gallons of groundwater. These samples had no headspace or air bubbles inside the bottles and were sealed underwater to avoid atmospheric contamination.

Dissolved noble gases were collected in $3 / 8$-inch-diameter copper tubes using reinforced nylon tubing connected to the hose bib at the wellhead. Groundwater was flushed through the tubing to dislodge bubbles before flow was restricted with a back pressure valve. Clamps on either side of the copper tube then were tightened, trapping a sample of groundwater for analyses of dissolved noble gases (Weiss, 1968).

Alkalinity was measured in the mobile laboratory at the well site on filtered samples by Gran's titration method (Gran, 1952) or the incremental titration method (Barnes, 1964; Yurewicz, 1981). Titration data were entered directly into PCFF and the concentrations of bicarbonate $\left(\mathrm{HCO}_{3-}\right)$ and carbonate $\left(\mathrm{CO}_{3}{ }^{2-}\right)$ automatically were calculated from the titration data using the advanced speciation method. Concentrations of $\mathrm{HCO}_{3-}$ and $\mathrm{CO}_{3}{ }^{2-}$ also were calculated from the laboratory alkalinity and $\mathrm{pH}$ measurements. Calculations were made in a spreadsheet using the advanced speciation method (http://or.water.usgs.gov/alk/methods.html) with $\mathrm{pK}_{1}=6.35, \mathrm{pK}_{2}=10.33$, and $\mathrm{pK}_{\mathrm{W}}=14$.

Surface-water samples were collected from multiple vertical segments across the width of the river channel using depth- and width-integrated sampling methods described in the USGS National Field Manual (U.S. Geological Survey, variously dated). These methods provided a sample that was representative of the entire river cross-section. Sampling equipment consisted of a standard USGS depth-integrated DH-81 hand-held sampler. All surface-water samples were collected using the DH-81 sampler with Teflon ${ }^{\circledR} 1$-L bottles, caps, and nozzles. Water samples for chemical analysis (trace elements, nutrients, major and minor ions, silica, TDS, alkalinity, and stable isotopes of nitrogen and oxygen in dissolved nitrate) were composited from the Teflon ${ }^{\circledR}$ bottles into a pre-rinsed Teflon ${ }^{\circledR}$ churn splitter and processed inside the mobile laboratory in the same fashion as the groundwater samples. Stable isotopes of hydrogen and oxygen in water samples were collected by dipping the $60-\mathrm{mL}$ clear glass bottle at the river centroid.

Nine laboratories performed chemical analyses for this study (table A1), although most of the analyses were performed at the NWQL or by laboratories contracted by the NWQL. The NWQL maintains a rigorous quality-assurance program (Pirkey and Glodt, 1998; Maloney, 2005). Laboratory quality-control samples, including method blanks, continuing calibration verification standards, standard reference samples, reagent spikes, external certified reference materials, and external blind proficiency samples are analyzed regularly. Method detection limits are tested continuously and laboratory reporting levels updated accordingly. NWQL maintains National Environmental Laboratory Accreditation Program (NELAP) and other certifications (http://www.nelac-institute. org/accred-labs.php). In addition, the USGS Office of Water Quality Branch of Quality Systems (BQS) within the USGS Office of Water Quality maintains independent oversight of quality assurance at the NWQL and laboratories contracted by the NWQL. The Branch of Quality Systems also runs the National Field Quality Assurance program that includes annual testing of all USGS field personnel for proficiency in making field water-quality measurements (http://qadata. cr.usgs.gov/nfqa/). Results for analyses made at the NWQL or 
by laboratories contracted by the NWQL are uploaded directly into NWIS by the NWQL.

Results from the USGS Branch of Quality Systems quality assurance program indicate negative analytical biases for boron and iron (each of 12 percent) and positive analytical biases for cadmium and uranium (of developing and 9.7 percent, respectively) during the time that SCRC samples were analyzed at the NWQL (U.S. Geological Survey Branch of Quality Systems, December 2008). The results suggest that boron and iron concentrations may be slightly underestimated and cadmium and uranium concentrations may be slightly overestimated.

\section{Data Reporting}

The following section gives details for the laboratory reporting conventions and the constituents that are determined by multiple methods or by multiple laboratories.

\section{Reporting Limits}

The USGS NWQL uses the laboratory reporting level (LRL) as a threshold for reporting analytical results. The LRL is set to minimize the reporting of false negatives (not detecting a compound when it actually is present in a sample) to less than 1 percent (Childress and others, 1999). The LRL usually is set at two times the long-term method detection level (LT-MDL). The LT-MDL is derived from the standard deviation of at least 24 method detection limit (MDL) determinations made over an extended period of time. The MDL is the minimum concentration of a substance that can be measured and reported with 99-percent confidence that the concentration is greater than zero (at the MDL there is less than 1 percent chance of a false positive). LT-MDLs continually are monitored and updated (Childress and others, 1999; U.S. Environmental Protection Agency, 2002). The USGS NWQL updates LRL values regularly and the values listed in this report were in effect during the period that analyses were made for groundwater samples from the SCRC study (May to December 2008).

Detections between the LRL and the LT-MDL are reported as estimated concentrations (coded by the letter E preceding the values in the tables and text). For informationrich methods, detections less than the LT-MDL have high certainty of detection, but the precise concentration is uncertain. Information-rich methods are those that utilize gas chromatography or high-performance liquid chromatography (HPLC) with mass spectrometry detection (VOCs, pesticides, and polar pesticides). Compounds are identified by presence of characteristic fragmentation patterns in their mass spectra in addition to being quantified by measurement of peak areas at their associated chromatographic retention times. E-coded values also may result from detections outside the range of calibration standards from detections that did not meet all laboratory quality-control criteria and from samples that were diluted prior to analysis (Childress and others, 1999).

Some constituents in this study are reported using minimum reporting levels (MRLs) or method uncertainties (MU). The MRL is the smallest measurable concentration of a constituent that may be reliably reported using a given analytical method (Timme, 1995). The method uncertainty generally indicates the precision of a particular analytical measurement; it gives a range of values wherein the true value will be found.

Results for most constituents are presented using the LRL or MRL values provided by the analyzing laboratories. Results for some constituents are presented using raised study reporting limits (SRLs) derived from assessment of data from quality-control samples associated with groundwater samples collected as part of the GAMA Priority Basins Project. The SRLs were determined by statistical assessment of results from the field blanks collected during the first 21 GAMA Priority Basins Project study units (May 2004 through January 2008) (Olsen and others, 2010). The statistical analysis used order statistical and binomial probabilities to construct an upper confidence limit for the amount of contamination potentially present in field blanks, and by inference, in groundwater samples (Hahn and Meeker, 1991). The upper confidence limit is the maximum concentration of a constituent for which there is a 90-percent confidence that no more than 10 percent of the groundwater samples might have a higher concentration of that constituent solely as a result of contamination of the groundwater sample during sample collection, handling, and analysis. This maximum concentration corresponds to the concentration in the field blank that is at the 95th percentile of the 86 field blanks used in the statistical assessment. For most constituents, this maximum concentration was less than the LRL or MRL for the constituent. Data for such constituents are reported with the LRL or MRL. For some constituents, this maximum concentration was greater than the LRL or MRL. An SRL then was defined as equal to the concentration in the 95th percentile field blank. Detections of those constituents reported by the laboratory with concentrations greater than the LRL or MRL but less than the SRL are reported in the tables with a less than or equal to $(\leq)$ symbol preceding the reported value.

The methods used for analysis of radiochemical constituents (gross alpha radioactivity and gross beta radioactivity) measure activities by counting techniques (table A1). The reporting limits for radiochemical constituents are based on sample-specific critical levels $\left(\mathrm{ssL}_{\mathrm{C}}\right)(\mathrm{McCurdy}$ and others, 2008). The critical level is analogous to the LT-MDL used for reporting analytical results for organic and non-radioactive inorganic constituents. Here, the critical level is defined as the minimum measured activity that indicates a positive detection of the radionuclide in the sample with less than a 5 percent probability of a false positive detection. Sample-specific critical levels are used for radiochemical measurements because the critical level is sensitive to sample size and sample yield during analytical processing and is 
dependent on instrument background, on counting times for the sample and background, and on the characteristics of the instrument being used and the nuclide being measured. An $\mathrm{SsL}_{\mathrm{C}}$ is calculated for each sample and the measured activity in the sample is compared to the $\mathrm{ssL}_{\mathrm{C}}$ associated with that sample. Measured activities less than the $\mathrm{ssL}_{\mathrm{C}}$ are reported as nondetections.

The analytical uncertainties associated with measurement of activities also are sensitive to sample-specific parameters, including sample size, sample yield during analytical processing, and time elapsed between sample collection and various steps in the analytical procedure, as well as parameters associated with the instrumentation. Therefore, measured activities of radioactive constituents are reported with samplespecific combined standard uncertainties (CSU) (table 14). Specifically, activities of gross alpha and gross beta radiation are reported with sample-specific CSU. The CSU is reported at the 68 percent confidence level (1-sigma).

\section{Notation}

Stable isotopic compositions of oxygen, hydrogen, nitrogen, carbon, and sulfur are reported as relative isotope ratios in units of per mil using the standard delta notation (Coplen and others, 2002):

$$
d^{i} E=\left[\frac{R_{\text {sample }}}{R_{\text {reference }}}-1\right] \times 1,000 \text { per mil }
$$

where

$$
\begin{aligned}
& i \quad \begin{array}{l}
\text { is } \begin{array}{l}
\text { the atomic mass of the heavier isotope of } \\
\text { element, }
\end{array} \\
\text { is the element (O for oxygen, } \mathrm{C} \text { for carbon, } \\
\text { N for nitrogen, } \mathrm{H} \text { for hydrogen, and } \\
\mathrm{S} \text { for sulfur), }
\end{array} \\
& \begin{array}{r}
R_{\text {sample }} \quad \text { is the ratio of the abundance of the heavier } \\
\text { isotope of the element }\left({ }^{18} \mathrm{O},{ }^{13} \mathrm{C},{ }^{15} \mathrm{~N},\right. \\
\left.{ }^{2} \mathrm{H},{ }^{34} \mathrm{~S}\right) \text { to the lighter isotope of the } \\
\text { element, }\left({ }^{16} \mathrm{O},{ }^{12} \mathrm{C},{ }^{14} \mathrm{~N},{ }^{1} \mathrm{H},{ }^{32} \mathrm{~S}\right) \text { in } \\
\text { the sample and, } \\
\text { the ratio of the abundance of the heavier } \\
\text { isotope of the element to the lighter isotope } \\
\text { of the element in the reference material. }
\end{array} \\
& R_{\text {reference }} \quad
\end{aligned}
$$

The reference material for oxygen and hydrogen is Vienna Standard Mean Ocean Water (VSMOW), which is assigned $\delta^{18} \mathrm{O}$ and $\delta^{2} \mathrm{H}$ values of 0 per mil (note than $\delta^{2} \mathrm{H}$ is sometimes written as $\delta \mathrm{D}$ because the common name of the heavier isotope of hydrogen, hydrogen-2, is deuterium). The reference material for carbon is Vienna Pee Dee Belemnite (VPDB), which is assigned a $\delta^{13} \mathrm{C}$ value of 0 per mil. The reference material for nitrogen is atmospheric nitrogen gas, which is assigned a $\delta^{15} \mathrm{~N}$ value of 0 per mil. The reference material for sulfur is Vienna Canon Diablo Troilite (VCDT), which is assigned a $\delta^{34} \mathrm{~S}$ value of 0 per mil. Positive values indicate enrichment of the heavier isotope and negative values indicate depletion of the heavier isotope, compared to the ratios observed in the standard reference material.

\section{Constituents on Multiple Analytical Schedules}

Twelve constituents targeted in this study were measured by more than one analytical schedule or by more than one laboratory (table A2). The preferred methods for these constituents were selected on the basis of the procedure recommended by the NWQL (http://wwwnwql.cr.usgs.gov/ dyn.shtml?Preferred method selection procedure). Methods with full approval are preferred over those with provisional approval and approved methods are favored over research methods. The method with greater accuracy and precision and lower LRLs for the overlapping constituents generally is preferred. However, the method with higher LRLs may be selected as the preferred method to provide consistency with historical data analyzed by the same method.

Some of the field water-quality indicators - $\mathrm{pH}$, specific conductance, and alkalinity - were measured in the field and at the NWQL. The field measurements are the preferred method for all three constituents $(\mathrm{pH}$, specific conductance, and alkalinity) because groundwater samples change once they are removed from the ambient environment; however, both measurements are reported.

Metalaxyl (a fungicide) was measured by two analytical schedules (2003 and 2060) at the NWQL and data from both methods are reported.

For arsenic and iron concentrations, the approved method, Schedule 1948, used by the NWQL is preferred over the research methods used by the USGS Trace Metal Laboratory. The concentrations measured by the Trace Metal Laboratory only are used to calculate ratios of redox species for each element, $\frac{\mathrm{As}(\mathrm{V})}{\mathrm{As}(\mathrm{III})}$ for arsenic and $\frac{\mathrm{Fe}(\mathrm{III})}{\mathrm{Fe}(\mathrm{II})}$ for iron. For
example:

$$
\frac{\mathrm{Fe}(\mathrm{III})}{\mathrm{Fe}(\mathrm{II})}=\frac{\mathrm{Fe}(\mathrm{T})-\mathrm{Fe}(\mathrm{II})}{\mathrm{Fe}(\mathrm{II})}
$$

where

$\mathrm{Fe}(\mathrm{T})$ is the total iron concentration (measured),

$\mathrm{Fe}(\mathrm{II})$ is the concentration of ferrous iron (measured), and $\mathrm{Fe}(\mathrm{III})$ is the concentration of ferric iron (calculated).

Tritium also is measured at two laboratories-Lawrence Livermore National Laboratory (LLNL) and U.S. Geological Survey Stable Isotope and Tritium Laboratory (SITL) — but only the data from SITL were available for reporting at the time of this publication. 


\section{Quality Assurance}

The purpose of quality assurance is to identify which data best represent environmental conditions and which may have been affected by contamination or bias during sample collection, processing, storage, transportation, or laboratory analysis. Four types of quality-control (QC) tests were used in this study: (1) blank samples were collected to assess positive bias as a result of contamination during sample handling or analysis, (2) replicate samples were collected to assess variability, (3) matrix spike tests were done to assess positive or negative bias, and (4) surrogate compounds were added to samples analyzed for organic constituents to assess bias of laboratory analytical methods. Results that were found to have significant contamination bias, on the basis of the QC data collected from this study and previous studies, were flagged with an appropriate remark code (described in subsequent sections) and rejected from subsequent use, including calculations of detection frequency.

The quality-assurance protocols used for this study followed the protocols used by the USGS NAWQA program (Koterba and others, 1995) and described in the USGS National Field Manual (U.S. Geological Survey, variously dated). The quality-assurance plan followed by the NWQL, the primary laboratory used to analyze samples for this study, is described in Maloney (2005) and Pirkey and Glodt (1998).

\section{Blanks}

The primary purposes of collecting blanks are to evaluate the magnitude of potential contamination of samples with analytes of interest during sample handling or analysis and to identify and mitigate these sources of sample contamination.

\section{Blank Collection and Analysis}

Blanks were collected using blank water certified by the NWQL to contain less than the LRL or MRL of the analytes investigated in the study (http://wwwnwql.cr.usgs.gov/USGS/ OBW/obw.html). Nitrogen-purged, organic-free blank water was used for blanks of organic constituents and inorganic-free blank water was used for blanks of other constituents. For SCRC, field and source-solution blanks were collected at up to 12 percent of the wells sampled and one equipment blank collected.

Field blanks were collected to assess potential contamination of samples during collection, processing, transport, and analysis. Source-solution blanks were collected to assess potential contamination of samples during transport and analysis, and potential contamination of the certified blank water obtained from the USGS NWQL. The equipment blank was collected at the USGS San Diego Projects Office to assess potential contamination of groundwater samples during collection by the Keck SP submersible sampling pump, which was used for the sampling of the environmental monitoring wells in the SCRC study unit.
Field blanks were analyzed for VOCs, pesticides and pesticide degradates, polar pesticides and metabolites, pharmaceuticals, perchlorate, NDMA, 1,2,3-TCP, trace elements, nutrients, DOC, major and minor ions, silica, TDS, arsenic and iron speciation, and gross alpha and gross beta radioactivity. Source-solution blanks were analyzed for VOCs, pharmaceuticals, perchlorate, NDMA, 1,2,3-TCP, trace elements, major and minor ions, silica, TDS, and arsenic and iron speciation. The equipment blank was analyzed for VOCs, pesticides and pesticide degradates, polar pesticides and metabolites, pharmaceuticals, perchlorate, NDMA, 1,2,3-TCP, trace elements, nutrients, DOC, major and minor ions, silica, TDS, and gross alpha and gross beta radioactivity.

Blanks were not collected for tritium or dissolved gases. Tritium and dissolved gases are in the atmosphere and would dissolve into any solution used in collecting a blank, making it impractical to collect a blank for these analytes. Stableisotopic ratios of carbon, hydrogen, oxygen, nitrogen, and sulfur are an intrinsic property of any of these elements; therefore, the concept of a blank does not apply to these ratios.

For field blanks, blank water either was pumped or poured through the sampling equipment (fittings and tubing) used to collect groundwater, then processed and transported using the same protocols used for the groundwater samples. Source-solution blanks were collected at the sampling site by pouring blank water directly into sample containers that were preserved, stored, shipped, and analyzed in the same manner as the groundwater samples. For the equipment blank, blank water was pumped through the Keck SP submersible sampling pump and Teflon ${ }^{\circledR}$ sample tubing, then processed and transported using the same protocols used for the groundwater samples. Eight to 12 liters of blank water were pumped or poured through the sampling equipment before each field and/or equipment blank was collected.

\section{Assessment of Blank Results}

Contamination in blanks may originate from several different types of sources that require different strategies for assessment of potential contamination of groundwater samples during sample collection, handling, and analysis. Four primary modes of contamination are assessed in the event of detections in blanks or atypical results in groundwater samples: (1) impurities in the water used to collect the blanks, (2) contamination during sample collection and handling from a known source or condition present at the field site, (3) carryover of material on the sampling equipment from one sample to the next sample, (4) systematic and random contamination from field and laboratory equipment and processes. The fourth source of contamination (systematic and random) is being addressed using a larger set of field blank results from multiple studies in addition to the results from blanks collected from SCRC. The development of this approach and its methods are described by Olsen and others (2010). 
The first potential mode evaluated is the presence of impurities in the water used to collect the blank. Because the blanks were collected using blank water certified by the NWQL to contain less than the LRL or MRL of the analytes investigated in the study, the blank water is rarely the source of constituents detected in blanks. However, blank water sometimes is used before the certification process has been completed; thus, the certificates of analysis always must be checked. Blank water used in the GAMA SCRC was certified by the NWQL prior to blank collection.

The second potential mode evaluated is contamination from identifiable, known sources present at a specific field site. Contamination from specific sources may produce distinctive patterns of detections in blanks and groundwater samples, particularly for the VOCs. Substances that may be encountered at the field site, such as cements used on PVC-piping, contain recognizable associations of VOC constituents. For example, cements used on PVC-piping are primarily composed of tetrahydrofuran with lesser amounts of acetone and methyl ethyl ketone (2-butanone). However, detection of these recognizable associations of VOC constituents in groundwater samples does not necessarily indicate contamination during sample collection because these VOC constituents also may occur together in groundwater.

If a recognizable association of VOC constituents was detected in a blank or in a groundwater sample, then the field notes and photographs from the site at which the sample was collected were examined for presence of conditions that may have resulted in contamination of the blank or groundwater sample during sample collection. If the constituents were present in the blank and groundwater sample from the same site at similar concentrations and the field notes or photographs indicated that the probable contaminant source was present, then the detections of those constituents in the groundwater sample were V-coded and all other groundwater samples collected at sites where the same condition may have occurred were considered for $\mathrm{V}$-coding. If the constituents were present in a groundwater sample and not the associated blank, or a groundwater sample from a site where no blanks were collected, and the field notes or photographs indicated that the presence of conditions that may have resulted in contamination of the groundwater sample during sample collection, the data were considered for V-coding. If no conditions that may have resulted in contamination of the groundwater sample during sample collection were identified in the field notes or photographs, then V-codes were not applied.

The third potential mode of contamination that was evaluated was carry-over from the previous groundwater sample or blank collected with the same equipment. Carryover between samples is rare because the procedures used to clean the equipment between samples have been developed and extensively tested to assure that carry-over is mitigated as much as possible. Potential carry-over was evaluated using time-series analysis to look for patterns suggestive of carry-over of constituents from a sample with high concentrations to the next groundwater sample or blank collected with the same equipment. If nondetections were reported in blanks or groundwater samples collected after the collection of groundwater samples containing high concentrations of the constituent, then carry-over as a mode of contamination was ruled out.

The fourth potential mode of contamination that was evaluated was random or systematic contamination from field or laboratory equipment or processes. All detections in blanks that could not be accounted for by impurities in the source-solution water, by specific known conditions at field sites, or by carry-over between samples were evaluated for random contamination. Random contamination in field and laboratory processes has an equal chance of affecting each groundwater sample; thus, strategies for flagging detections of constituents that are subject to random contamination in field and laboratory processes must be applied to all groundwater samples.

Different notation was used for flagging detections of organic and inorganic constituents that may have been subjected to contamination during sample collection, handling, and analysis. Inorganic constituents naturally are present in groundwater and the concerns about inorganic constituents generally are related to concentration, rather than to detection (presence or absence). In contrast, concerns about organic constituents generally are related to both detection and concentration. Therefore, different schemes are used for assessing and flagging data for organic and inorganic constituents.

For organic constituents, V-codes were applied. The purpose of V-coding was to flag detections that have a greater chance of being false-positive detections. A false-positive detection is a detection that is caused by contamination during sample collection, handling, and analysis of a groundwater sample that would otherwise have a non-detection for that constituent. Results with V-codes were not considered detections of the constituent for this study and were not included in calculations of detection frequencies for organic constituents (tables 5, 9, and A3).

The V-coding level was defined as the highest concentration of the constituent detected in a field blank plus the LT-MDL (equal to one-half the LRL) for that constituent. Detections of the constituent in groundwater samples at concentrations less than this V-coding level were flagged with a $\mathrm{V}$ preceding the reported value in the data tables. The highest concentration measured in a blank was assumed to represent the highest potential amount of contamination. Thus, the V-code flags the results that could have changed from non-detection to a detection, relative to the LT-MDL, because of contamination. Results with V-codes were not considered detections of the constituent for this study and were not included in calculations of detection frequencies for organic constituents. 
For inorganic constituents, a less than or equal to symbol $(\leq)$ was used to identify low-concentration detections of constituents that may have been affected by contamination. The $\leq$ symbol signifies that the concentration of the constituent in the groundwater sample is less than or equal to the measured concentration (including the possibility that it may be less than the LT-MDL and, therefore, a non-detection). For select trace elements (aluminum, barium, chromium, copper, lead, manganese, mercury, nickel, tungsten, vanadium, and zinc), the concentration cutoff, hereinafter referred to as the study reporting limit, SRL, for applying the $\leq$ symbol was determined from a statistical assessment of results for 86 field blanks collected between May 2004 and January 2008. The concentration threshold for applying the $\leq$ symbol was equal to the concentration of the field blank ranked at the 90 percent confidence level for the 90th percentile of the binomial distribution of the 86 field blanks (Olsen and others, 2010).

For all other inorganic constituents, the SRL for applying the $\leq$ symbol was determined from assessment of the blanks collected in SCRC and was defined as equal to the highest concentration measured in the seven blanks collected in SCRC (blanks were collected at 10 percent of the wells sampled). In the data tables, $\mathrm{a} \leq$ symbol preceded measured values that were less than the threshold concentration (tables 8 and $\underline{A} 3$ ). Future reports in this series will use the approach of Olsen and others (2010) for all inorganic constituents.

\section{Replicates}

Sequential replicate samples were collected to assess the precision of the water-quality data. Estimates of data precision are needed to assess whether differences between concentrations in samples are due to differences in groundwater quality or to variability that may result from collecting, processing and analyzing the samples. Replicate analyses were made on up to 12 percent of the samples collected in the SCRC study unit (tables A4A-C).

Two methods for measuring variability were needed to adequately assess precision over the broad range of measured concentrations of most constituents. The variability between measured concentrations in the pairs of sequential replicate samples was represented by the standard deviation (SD) for low concentrations and by relative standard deviation (RSD) for high concentrations (Anderson, 1987; Mueller and Titus, 2005). The RSD is defined as the SD divided by the mean concentration for each replicate pair of samples expressed as a percentage. The boundary between concentrations for which variability is assessed with SD and concentrations for which variability is assessed with RSD was defined as five times the LRL for each constituent.
For this study, acceptable precision for replicate sample pairs is defined as follows:

- For concentrations less than five times the LRL ( $<5 \mathrm{LRL}$ ), an SD of less than 10 percent is acceptable.

- For concentrations greater than (or equal to) five times the LRL ( $\geq 5$ LRL), an RSD of less than 10 percent is acceptable. For comparison, an RSD of 10 percent is equivalent to a relative percent difference (RPD) of 14 percent.

- For activities of radiochemical constituents, the presence of overlap between the results (value \pm 1-sigma CSU) is acceptable.

If results from replicate sample pairs indicate that precision is unacceptable for a constituent and no specific reason can be identified, then this greater variability must be considered when the data are used for the purposes of comparison. If measured concentrations are slightly above a water-quality threshold, then actual concentrations could be slightly below that threshold. Similarly, if measured concentrations are slightly below a water-quality threshold, then actual concentrations could be slightly above. If a constituent has high variability in replicate sample pairs, then a larger difference between concentrations measured in two samples is required to conclude that the two samples have significantly different concentrations.

For organic and inorganic constituents (except for radiochemical constituents), if both values for a replicate sample pair were reported as detections, then the SD was calculated if the mean concentration was $<5$ LRL for the constituent or the RSD was calculated if the mean concentration was $\geq 5 \mathrm{LRL}$ for the constituent. If both values were reported as nondetections, then the variability was set to zero by definition. Cases other than two detections or two nondetections were treated as follows:

- For organic constituents, if one or both values were assigned a V-code, then neither SD nor RSD was calculated. A V-code indicates that the constituent was detected in blanks and was excluded from the dataset of groundwater-quality results. The data might not represent the concentration of the constituent in the groundwater sample.

- For organic and inorganic constituents, if one value was reported as a non-detection, and the other value was reported as a detection less than the LRL, then a value of zero was substituted for the non-detection and the SD calculated. Substituting zero for the nondetection yields the maximum estimate of variability for the replicate pair. 
- For inorganic constituents, if one value for a sample pair was reported as a non-detection and the other value was reported as a $\leq$-coded value less than the $\mathrm{SRL}$, or if both values were reported as $\leq$-coded values less than the SRL, then neither SD nor RSD was calculated because the values may be analytically identical. The $\leq$-code indicates that the value is a maximum potential concentration and that concentration may be low enough to be reported as a non-detection.

- For organic and inorganic constituents, if one value was reported as a non-detection and the other value was reported as a detection greater than the LRL, then the variability for the pair was considered unacceptable.

\section{Matrix Spikes}

Addition of a known concentration of a constituent (spike) to a replicate environmental sample enables the analyzing laboratory to determine the effect of the matrix, in this case groundwater, on the analytical technique used to measure the constituent. The known compounds added in matrix spikes are the same as those being analyzed in the method. This enables an analysis of matrix interferences on a compound-by-compound basis. For this study, matrix spikes were added by the laboratory performing the analysis. Low matrix-spike recovery may indicate that the compound might not be detected in some samples if it were present at very low concentrations. Low and high matrix-spike recoveries may be a potential concern if the concentration of a compound in a groundwater sample is close to the MCL; a low recovery could result in a falsely measured concentration less than the MCL, whereas a high recovery could result in a falsely measured concentration greater than the MCL.

The GAMA Priority Basins Project defined the dataquality objective range for acceptable matrix-spike recoveries as 70 to 130 percent. Only constituents with matrix spike recoveries outside of this range were flagged as having unacceptable recoveries; they were in tables $3 \mathrm{~B}$ and $\underline{3 \mathrm{C}}$. For many constituents, an acceptable range of 70 to 130 percent for median matrix-spike recovery was more restrictive than the acceptable control limits for laboratory-set spike recoveries. Laboratory-set spikes are aliquots of laboratory blank water to which the same spike solution used for the matrix-spikes has been added. One set spike is analyzed with each set of samples. Acceptable control limits for set spikes are defined relative to the long-term variability in recovery. For example, for many NWQL schedules acceptable set spike recovery is within \pm 3 F-pseudosigma of the median recovery for at least 30 set spikes (Conner and others, 1998). The F-pseudosigma is calculated by dividing the fourth-spread (analogous to interquartile range) by 1.349 ; therefore, the smaller the
F-pseudosigma the more precise the determinations (Hoaglin, 1983).

Matrix spikes were performed for VOCs, pesticides and pesticide degradates, polar pesticides and metabolites, pharmaceuticals, perchlorate, NDMA, 1,2,3-TCP, and gross alpha and gross beta radioactivity because the analytical methods for these constituents may be susceptible to matrix interferences. Replicate samples for matrix-spike additions were collected at approximately 11 percent of the wells sampled although not all analyte classes were tested at every well (tables A5A-E).

\section{Surrogates}

Surrogate compounds are added to environmental samples in the laboratory prior to analysis to evaluate the recovery of similar constituents. Surrogate compounds were added to all groundwater and quality-control samples that were analyzed for VOCs, pesticides and pesticides degradates, and polar pesticides and metabolites (table A6). Most of the surrogate compounds are deuterated analogs of compounds being analyzed. For example, the surrogate toluene- $d 8$ that is used for the VOC analytical method has the same chemical structure as toluene, except that the eight hydrogen-1 atoms on the molecule have been replaced by deuterium (hydrogen-2). Toluene- $d 8$ and toluene behave very similarly in the analytical procedure, but the small mass difference between the two results in slightly different chromatographic retention times; thus, the use of a toluene- $d 8$ surrogate does not interfere with the analysis of toluene (Grob, 1995). Only 0.015 percent of hydrogen atoms are deuterium (Firestone and others, 1996); thus, deuterated compounds like toluene- $d 8$ do not occur naturally and are not detected in environmental samples. Surrogates are used to identify general problems that may arise during laboratory sample analysis that could affect the analysis results for all compounds in that sample. Potential problems include matrix interferences (such as high levels of DOC) that produce a positive bias or incomplete laboratory recovery (possibly because of improper maintenance and calibration of analytical equipment) that produces a negative bias. A 70 to 130 percent recovery of surrogates, in general, is considered acceptable; values outside this range indicate possible problems with the processing and analysis of samples (Connor and others, 1998; Sandstrom and others, 2001).

\section{Quality-Control Results}

\section{Detections in Field and Source-Solution Blanks and Equipment Blank}

Field and source-solution blanks were collected at up to approximately 12 percent of the sites sampled in SCRC. Table A3 presents a summary of detections in the field and source-solution blanks and the equipment blank. 
1,2,4-Trimethylbenzene, toluene, and 1,1-Dichloroethene (1,1-DCE) were the only VOCs detected in blanks that also were detected in groundwater samples. Detections of 1,2,4-trimethylbenzene also were reported in blanks from other GAMA Priority Basins Project study units. Concentrations of 1,2,4-trimethylbenzene between E0.02 and $0.56 \mu \mathrm{g} / \mathrm{L}$ were detected in approximately 5 percent of the field and source-solution blanks from the 27 GAMA Priority Basins Project study units sampled to date from 2004 through 2008 (Kulongoski and others, 2006, 2007; Dawson and others, 2008; Schmitt and others, 2008; Fram and others, 2009; Kent and Belitz, 2009). Approximately 91 percent of the concentrations of 1,2,4-trimethylbenzene detected in groundwater samples from the 27 GAMA Priority Basins Project study units sampled to date were less than or equal to $0.12 \mu \mathrm{g} / \mathrm{L}$ (greater than the concentration detected in the SCRC field blank, $0.08 \mu \mathrm{g} / \mathrm{L}$ ). The source of the 1,2,4-trimethylbenzene is unknown. The concentrations at which 1,2,4-trimethylbenzene was detected in both the groundwater samples and the blanks suggest that groundwater samples and blanks were randomly contaminated with 1,2,4-trimethylbenzene from an unknown source while being collected, handled, transported, and/or analyzed. Because the source of the 1,2,4-trimethylbenzene in blanks is unknown and the pattern of detections in blanks and groundwater samples from other GAMA Priority Basins Project study units sampled to date indicates the potential for random contamination, 1,2,4-trimethylbenzene detections in groundwater samples collected in all GAMA Priority Basins Project study units are subject to V-coding. As a result, concentrations of 1,2,4-trimethylbenzene detected in 18 groundwater samples in SCRC were V-coded as nondetections (tables 5 and $\mathrm{A} 3$ ).

The blank detections in SCRC for toluene, and 1,1-DCE also were considered to be random contamination, which has an equal chance of affecting each groundwater sample. Therefore, strategies for flagging detections of constituents that are subject to random contamination must be applied to all groundwater samples. Toluene was detected in two field blanks at concentrations of 0.18 and E0 $0.03 \mu \mathrm{g} / \mathrm{L}$. The former of these detections created a V-coding level of $0.19 \mu \mathrm{g} / \mathrm{L}$ $(0.18 \mu \mathrm{g} / \mathrm{L}$ plus one-half the LRL of $0.02 \mu \mathrm{g} / \mathrm{L})$. Toluene was detected at concentrations less than the $\mathrm{V}$-coding level in two groundwater samples and both detections were V-coded as nondetections (tables 5 and $\underline{\mathrm{A} 3}$ ). 1,1-DCE was detected in one source-solution blank at E0.03 $\mu \mathrm{g} / \mathrm{L}$. This detection created a V-coding level of $0.04 \mu \mathrm{g} / \mathrm{L}(\mathrm{E} 0.03 \mu \mathrm{g} / \mathrm{L}$ plus one-half the LRL of $0.02 \mu \mathrm{g} / \mathrm{L}$ ). None of the 1,1-DCE concentrations measured for groundwater samples were less than $0.04 \mu \mathrm{g} / \mathrm{L}$; therefore, values were not V-coded (table 5).

Trace-element data were assessed for potential flagging of results using the GAMA study reporting limits (SRLs), which are based on results for 86 field blanks collected between May 2004 and January 2008 in conjunction with the three field and source-solution blanks collected in SCRC and the single equipment blank. Aluminum, barium, chromium, copper, lead, manganese, mercury, nickel, tungsten, vanadium, and zinc have SRLs previously determined by the field blank study described in the appendix section titled "Assessment of Blank Results." Measured values that are less than the SRL are flagged with a $\leq$ symbol in table 8 . Field and sourcesolution blanks were collected at 3 of the 42 groundwater sites sampled, in conjunction with the equipment blank, for analysis of trace elements. Five trace elements were detected in one blank; chromium $(2.2 \mu \mathrm{g} / \mathrm{L})$, copper $(2.3 \mu \mathrm{g} / \mathrm{L})$, lead $(0.31 \mu \mathrm{g} / \mathrm{L})$, nickel $(0.25 \mu \mathrm{g} / \mathrm{L})$, and zinc $(11.5 \mu \mathrm{g} / \mathrm{L})$ (table A3). All detections of these trace metals less than their SRL levels were flagged with $a \leq$ symbol (tables 8 and A3). There were no other trace metals detected in any of the blanks in the SCRC.

Field blank and source-solution blanks were collected at 3 of the 45 groundwater sites sampled, in conjunction with the equipment blank for analysis of nutrients. Field blanks were collected at 3 of the 37 groundwater sites sampled for the analysis of DOC.

All nutrient and DOC blank detections in the SCRC were considered to be random contamination, which has an equal chance of affecting each water sample. Therefore, strategies for flagging detections of constituents that are subject to random contamination must be applied to all water samples.

Ammonia (as nitrogen) was detected in one field blank at a concentration of E0.01 mg/L, creating a V-coding level of $0.02 \mathrm{mg} / \mathrm{L}(0.01 \mathrm{mg} / \mathrm{L}$ plus one-half the LRL of $0.02 \mathrm{mg} / \mathrm{L})$. Ammonia (as nitrogen) was detected at a concentration of $\mathrm{E} 0.02 \mathrm{mg} / \mathrm{L}$ in one grid well sample (SCRC-H08) and one surface-water sample (SCRC-SW1) (table 9). The measured concentration of total nitrogen from SCRC-H08 equaled the sum of all filtered nitrogen analytes (ammonia + nitrate + nitrite + organic-nitrogen); therefore, the field blank detection was not of potential concern for this sample (table 9). The sampling equipment used in the collection of surface-water samples is markedly different than the sampling equipment used in the collection of groundwater and field-blank samples. As a result, the field-blank detection of ammonia (as nitrogen) was not of potential concern for the SCRC-SW1 sample (table 9).

Total nitrogen (ammonia + nitrate + nitrite + organicnitrogen) was detected in one field blank at a concentration of $0.12 \mathrm{mg} / \mathrm{L}$, creating a V-coding level of $0.15 \mathrm{mg} / \mathrm{L}(0.12 \mathrm{mg} / \mathrm{L}$ plus one-half the LRL of $0.06 \mathrm{mg} / \mathrm{L}$ ). Total nitrogen was detected at a concentration less than the V-coding level in four groundwater samples in SCRC. The sum of the filtered nitrogen analytes (ammonia + nitrate + nitrite + organicnitrogen) was equal to or within 10 percent relative percent difference (U.S. Geological Survey National Water Quality Laboratory acceptance criteria for total nitrogen and the sum of the filtered nitrogen analytes) of the measured concentration of the associated total nitrogen result; therefore, the blank detection was not of potential concern for these four groundwater samples (table 9 ). 
Phosphate, orthophosphate (as phosphorus) was detected in the equipment blank at a concentration of E0.004 mg/L, creating a V-coding level of $0.007 \mathrm{mg} / \mathrm{L}$ (E0.004 mg/L plus one-half the LRL of $0.006 \mathrm{mg} / \mathrm{L})$. Equipment blank detections potentially can affect only the groundwater samples collected with the Keck SP submersible sampling pump, which was used for the sampling of the environmental monitoring wells in SCRC. Phosphate was not detected in groundwater samples from the environmental monitoring wells. Orthophosphate (as phosphorus) concentrations were less than $0.007 \mathrm{mg} / \mathrm{L}$; therefore, values were not $\mathrm{V}$-coded as a result of the equipment-blank detection (table 9).

DOC was detected at a concentration of E0.3 $\mathrm{mg} / \mathrm{L}$ in one field blank and low concentrations of DOC were detected in field blanks collected in previous GAMA Priority Basins Project study units (Bennett and others, 2006; Kulongoski and Belitz, 2007; Mathany and Belitz, 2009). Thus, the data for all groundwater samples with concentrations equal to or less than E0.5 mg/L (0.3 mg/L plus one-half the LRL of $0.4 \mathrm{mg} / \mathrm{L})$ were $\mathrm{V}$-coded as nondetections (tables 9 and $\underline{\mathrm{A} 3}$ ).

Field and source-solution blanks were collected at 3 of the 42 groundwater sites in SCRC in conjunction with the equipment blank for analysis of major and minor ions, silica, and TDS. Chloride was detected in one field blank resulting in a study reporting limit (SRL) at $0.48 \mathrm{mg} / \mathrm{L}$. This blank detection was considered to be random contamination, which has an equal chance of affecting each groundwater sample; thus, none of the choride concentrations in all groundwater samples less than the SRL value were subject to flagging. None of the chloride concentrations in groundwater samples were less than $0.48 \mathrm{mg} / \mathrm{L}$; therefore, none of the values were flagged with a $\leq$ symbol (table 10). Silica was detected in two field blanks resulting in a SRL at E0.013 mg/L (the higher of the two detected concentrations, E0.013 mg/L and $\mathrm{E} 0.012 \mathrm{mg} / \mathrm{L}$ ). This blank detection also was considered to be random contamination; thus, all silica concentrations in groundwater samples less than the SRL value were subject to flagging. None of the silica concentrations in groundwater samples were less than E0.013 $\mathrm{mg} / \mathrm{L}$; therefore, none of the values were flagged with $\mathrm{a} \leq$ symbol (table 10 ).

Constituents were not detected in the blanks for the following analyte groups: pesticides and pesticide degradates (six field blanks and one equipment blank); polar pesticides and metabolites (six field blanks and one equipment blank); perchlorate (six field blanks, seven source-solution blanks, and one equipment blank); NDMA (three field blanks, four source-solution blanks, and one equipment blank); 1,2,3TCP (six field blanks, seven source-solution blanks, and one equipment blank); arsenic and iron species analysis at the USGS Trace Metal Laboratory (three field blanks and one source-solution blank); and gross alpha and gross beta radioactivity (72-hour and 30-day counts) (two field blanks and one equipment blank).

\section{Variability in Replicate Samples}

Tables A4A-C summarize the results of replicate analyses for constituents detected in groundwater samples collected in the SCRC. Of the 1,968 replicate pairs of constituents analyzed, 537 were for constituents detected in at least one groundwater sample. Of these 537 pairs, 2 pairs (boron and iron [total]) were outside the limits for acceptable precision. Results for replicate analyses for constituents that were not detected are not reported in tables A4-C.

Eight replicate pairs of samples were analyzed for the 85 VOCs and all pairs yielded two values reported as nondetections with the exception of four replicate pairs of 1,2,4-Trimethylbenzene and one replicate pair each of dichlorodifluoromethane (CFC-12), trichlorofluoromethane (CFC-11), and tetrachloroethene.

All four replicate pairs for 1,2,4-Trimethylbenzene consisted of values reported as one non-detection and one detection greater than the $\operatorname{LRL}(0.04 \mu \mathrm{g} / \mathrm{L})$. All four of these replicate pairs yielded V-coded values (tables 5 and A4A). Variability was not assessed for the four pairs with $\mathrm{V}$-coded data because the data are not considered representative of the composition of the groundwater.

The replicate pair for dichlorodifluoromethane (CFC-12), perchloroethene (PCE, tetrachloroethene), and trichlorofluoromethane (CFC-11) yielded two values reported as detections and all replicate pair analysis resulted in SDs within acceptable precision (table A4A).

All eight replicate pairs for the 63 pesticide and pesticide degradate compounds were analyzed and produced nondetections with the exception of one replicate pair of 1-Naphthol. This replicate pair had one non-detection and one detection of E0.006 $\mu \mathrm{g} / \mathrm{L}$, well below the LRL of $0.04 \mu \mathrm{g} / \mathrm{L}$. Following replicate analysis procedures explained in section, "Assessment of Replicate Variability," a value of zero was assigned to the non-detection and the SD of the replicate pair then was calculated. This replicate pair analysis resulted in an SD within the acceptable range of less than 10 percent. 1-Naphthol was not detected in any groundwater samples; therefore this replicate analysis is not represented in table A4A.

Eight replicate pairs for the 60 polar pesticide and metabolite compounds were assessed and all pairs consisted of nondetections with the exception of one replicate pair of Deethylatrazine (2-Chloro-4-isopropylamino-6-amino- $s$ triazine), which had one non-detection and one detection less than the LRL. The replicate pair analysis resulted in an SD within the acceptable range for this deethylatrazine replicate pair. Deethylatrazine was not detected by the NWQL on the analytical Schedule 2060; therefore, this replicate analysis is not reflected in table A4A. 
Replicate pairs for the constituents of special interest (perchlorate [seven pairs], NDMA [seven pairs], and 1,2,3TCP [five pairs]) were analyzed at Weck Laboratories, Inc., for variability. Five of the seven replicate pairs for perchlorate consisted of two values reported as detections and all analysis resulted in SDs or RSDs within the acceptable range of less than 10 percent (table A4A). The two remaining replicate pairs for perchlorate and all replicate pairs for NDMA and 1,2,3-TCP were yielded 'two values reported as nondetections.

Replicate pairs of samples were analyzed for trace elements (five pairs), nutrients (one to six pairs), major and minor ions (five to six pairs), silica (six pairs), TDS (six pairs), alkalinity (five pairs), and isotope tracers (three to nine pairs), and the SD or RSD values for all pairs were within the acceptable range of less than 10 percent with the exception of one replicate pair of boron (table A4B). The RSD value for the replicate pair for boron was 19 percent; however, the environmental concentration was just greater than one-third and the replicate sample concentration was just greater than one-half of the corresponding NL-CA (tables $3 \mathrm{~F}$ and 8 ). The less than acceptable precision for this constituent at concentrations less than health-based thresholds will not affect the assessments of groundwater quality being made by the GAMA Priority Basins Project.

Five replicate pairs were analyzed for species of arsenic and iron by the USGS Trace Metals Laboratory in Boulder, Colorado. One replicate pair analyzed for arsenic (total), three pairs of species of arsenic (III), and two pairs of iron (II) yielded two non-detection values. Four replicate pairs analyzed for arsenic (total), two pairs of species of arsenic (III), four pairs of arsenic (III), and two pairs of iron (II) consisted of two values reported as detections, and all replicate pair analysis resulted in SDs or RSDs within acceptable precision with the exception of one replicate pair of iron (total) (table A4B). The RSD value for this replicate pair was 22 percent; however, this less than acceptable precision for this constituent is not of potential QC concern for the GAMA Priority Basins Project. As explained in the appendix section titled "Constituents on Multiple Analytical Schedules," iron concentrations reported from the NWQL are preferred over the research methods used by the USGS Trace Metal Laboratory. The remaining replicate pairs (one for iron [total] and one for iron [II]) each produced one non-detection and one detection reported at concentrations greater than the LRL. These less than acceptable results are not of QC concern for the GAMA Priority Basins Project because values generated from the NWQL are preferred over values from the USGS Trace Metal Laboratory.

Four replicate pairs for gross alpha and gross beta radioactivity ( 72 hour and 30 day) were analyzed for variability. Acceptable precision for radiochemical constituents is defined as the presence of overlap between the results (value \pm 1 -sigma CSU) for the two analyses where the range between the lower confidence limit of the activity measured in the groundwater sample and the upper confidence limit of the activity measured in the groundwater sample overlaps the range between the lower confidence limit of the activity measured in the replicate groundwater sample and the upper confidence limit of the activity measured in the replicate groundwater sample. Two replicate pairs for gross alpha radioactivity ( 72 hour), three pairs for gross alpha radioactivity (30 day), and all four pairs for gross beta radioactivity ( 72 hour and 30 day) yielded overlapping values and were, therefore, considered acceptable (table A4C). The gross alpha radioactivity ( 72 hour and 30 day) replicate pairs yielding non-overlapping values were all at activities less than the MCL-US of $15 \mathrm{pCi} / \mathrm{L}$ (tables $3 \mathrm{~J}$ and 14 ); therefore, the less than acceptable precision at these low activities will not affect the assessments of groundwater quality being made by the GAMA Priority Basin Project.

Environmental detections were not modified on the basis of the replicate analysis.

\section{Matrix-Spike Recoveries}

Tables A5A-E presents a summary of matrix-spike recoveries for the SCRC. The addition of a spike or known concentration of a constituent to an environmental sample enables the analyzing laboratory to determine the effect of the matrix, in this case groundwater, on the analytical technique used to measure the constituent.

Seven environmental samples were spiked with VOCs to calculate matrix-spike recoveries. Median matrix-spike recoveries for all 85 VOC spike compounds were within the acceptable range of 70 to 130 percent (table A5A). One matrix-spike recover for two VOC spike compounds - perchloroethene (PCE, tetrachloroethene) and trichlorofluoromethane (CFC-11) - were greater than 130 percent and both these VOCs also were detected in groundwater samples (tables $3 \mathrm{~A}$ and $\underline{5}$ ). At least one matrixspike recover for four VOC spike compounds - bromomethane (methyl bromide), carbon disulfide, dichlorodifluoromethane (CFC-12), and styrene - were less than 70 percent. Of these VOC spike compounds, dichlorodifluoromethane (CFC-12) also was detected in groundwater samples (tables $3 \mathrm{~A}, \underline{5}$, and A5A). (Note: Low recoveries may indicate that the compound might be present at very low concentrations but not detected in some samples).

Six groundwater samples were spiked with pesticide and pesticide degradate compounds to calculate matrix-spike recoveries. Median matrix-spike recoveries for 43 of the 63 spike compounds were within the acceptable range of 70 to 130 percent (table A5B). The median matrix-spike recoveries for 10 of the 11 compounds detected in groundwater samples were within the acceptable range (tables 3B and 6A). 
Median spike-matrix recovery for deethylatrazine (2-Chloro4-isopropylamino-6-amino- $s$-triazine) was less than the acceptable range (52 percent). At least one matrix spike recovery for three pesticide and pesticide degradate spike compounds was greater than 130 percent and one matrix-spike recovery was less than 70 percent, although none of these compounds were detected in any groundwater samples. At least one matrix-spike recovery for 45 pesticide and pesticide degradate spike compounds was less than 70 percent. Of these pesticide and pesticide degradate spike compounds, deethylatrazine, simazine, metolachlor, 3,4-Dichloroaniline, acetochlor, fipronil sulfide, fipronil sulfone, and prometon also were detected in groundwater samples (tables 3B, $\underline{6 \mathrm{~A}}$, and $\underline{\mathrm{A} 5 \mathrm{~B}}$ ).

Eight groundwater samples were spiked with polar pesticide and metabolite compounds to calculate matrixspike recoveries. Matrix-spike recoveries for 45 of the 60 spike compounds were within the acceptable range of 70 to 130 percent (table A5C). Median matrix-spike recoveries for three of the four compounds detected in groundwater samples were within the acceptable range. Median matrixspike recovery for 3-(4-chlorophenyl)-1-methyl urea was less than the acceptable range (58 percent) (tables $3 \mathrm{C}$ and $\underline{6 \mathrm{~B}}$ ). Median matrix-spike recovery for nicosulfuron was greater than the acceptable range (188 percent), but nicosulfuron was not detected in any groundwater samples. At least one matrix-spike recovery for 3 polar pesticide and metabolite spike compounds was greater than 130 percent; at least one matrix-spike recovery for 6 spike compounds was greater than 130 percent and one matrix-spike recovery was less than 70 percent; and at least one matrix-spike recovery for 41 spike compounds was less 70 percent. Of these polar pesticide and metabolite spike compounds, diuron, 3-(4-Chlorophenyl)1-methyl urea, bromacil, and fenuron also were detected in groundwater samples (tables 3C, $\underline{6 \mathrm{~B}}$, and $\underline{\mathrm{A} 5 \mathrm{C}}$ ).
Four groundwater samples were spiked with perchlorate, two with NDMA, and six with 1,2,3-TCP to calculate matrixspike recoveries at Weck Laboratories, Inc. All median matrix-spike recoveries were within the acceptable range of 70 to 130 percent (table A5D). One matrix-spike recovery for NDMA was less than 70 percent and was not detected in groundwater samples (tables 3E and A5D).

Three groundwater samples were spiked with gross alpha and gross beta radiation to calculate matrix-spike recoveries. All matrix-spike recoveries were within the acceptable range of 70 to 130 percent (table A5E).

Environmental detections were not modified on the basis of the matrix-spike analysis.

\section{Surrogate Compound Recoveries}

Surrogate compounds were added to environmental samples in the laboratory and analyzed to evaluate the recovery of similar constituents. Table A6 lists the surrogate, the analytical schedule on which it was applied, the number of analyses for blank and environmental samples, the number of surrogate recoveries less than 70 percent, and the number of surrogate recoveries greater than 130 percent for the blank and groundwater samples. Blank and environmental samples were considered separately to assess whether the matrixes present in groundwater samples affect surrogate recoveries.

In SCRC, most surrogate recoveries were within the acceptable range of 70 to 130 percent. In total, 81 percent of the surrogate recoveries for VOC, 91 percent of the surrogate recoveries for pesticide and pesticide degradate, and 73 percent of the surrogate recoveries for polar pesticide and metabolite analyses were within the acceptable range.

Environmental detections were not modified on the basis of the surrogate recovery analysis. 


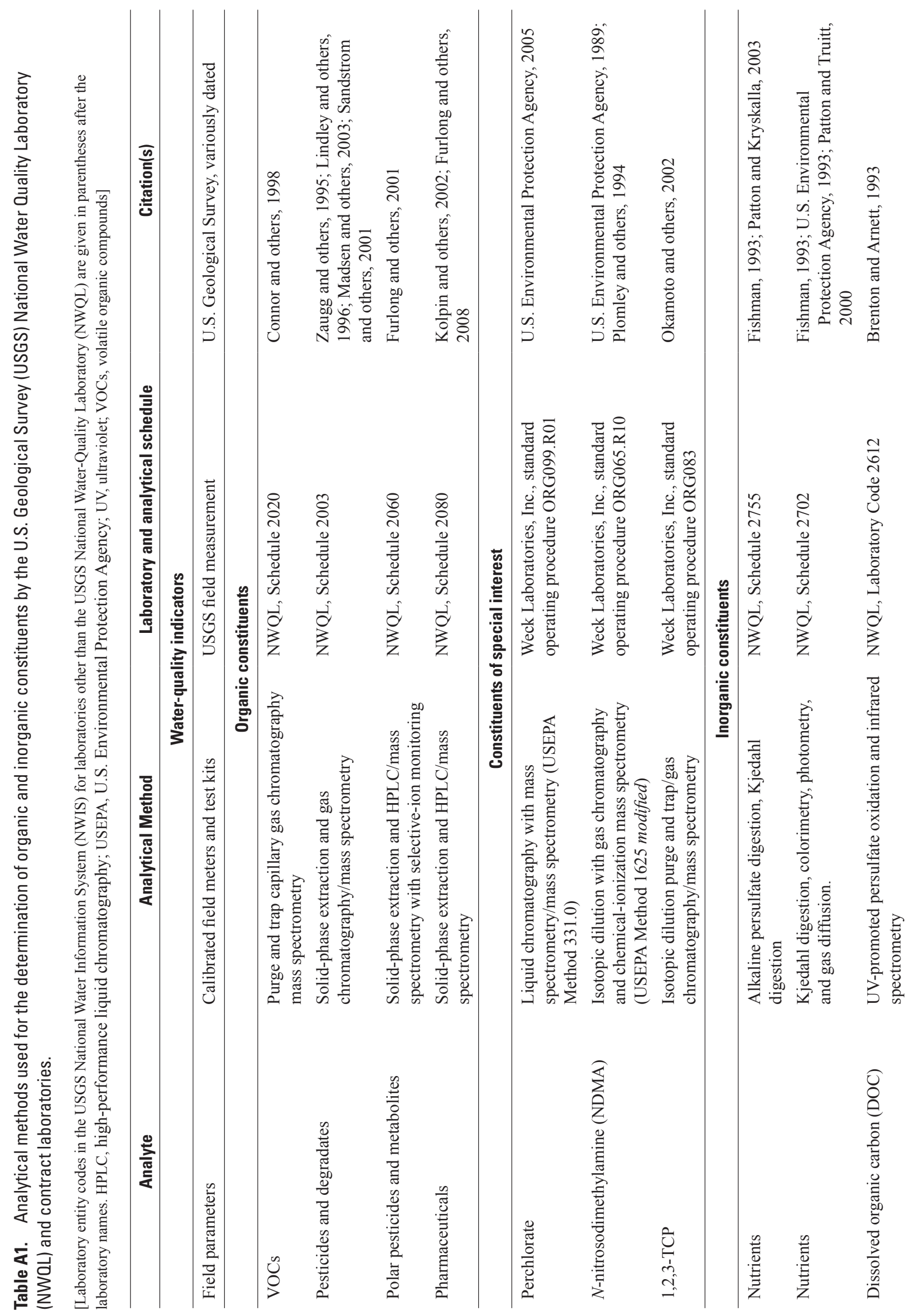




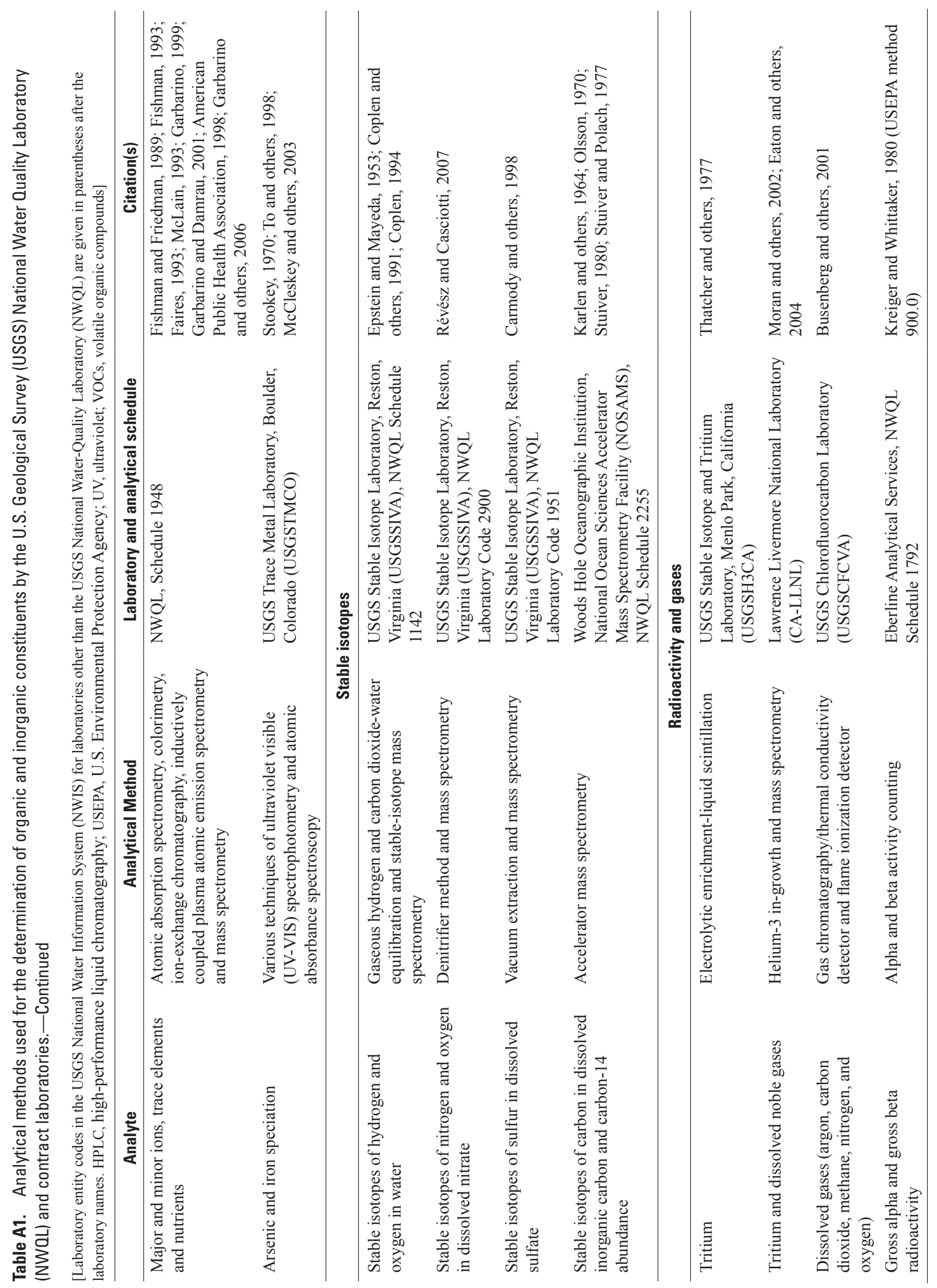


Table A2. Preferred analytical schedules for constituents appearing on multiple schedules for samples collected for the South Coast Range-Coastal (SCRC) Groundwater Ambient Monitoring and Assessment (GAMA) study, California, May to December 2008.

['Abbreviations: LLNL, Lawrence Livermore National Laboratory; SITL, U.S. Geological Survey Stable Isotope and Tritium Laboratory; TML, U.S. Geological Survey Trace Metal Laboratory, Boulder, Colorado; VOC, volatile organic compound; np, no preference]

\begin{tabular}{|c|c|c|c|}
\hline Constituent & $\begin{array}{l}\text { Primary constituent } \\
\text { classification }\end{array}$ & $\begin{array}{l}\text { Analytical } \\
\text { schedules }\end{array}$ & $\begin{array}{l}\text { Preferred } \\
\text { analytical } \\
\text { schedule }\end{array}$ \\
\hline \multicolumn{4}{|c|}{ Results from preferred method reported } \\
\hline Atrazine & Pesticide & 2003,2060 & 2003 \\
\hline Caffeine & Wastewater indicator & 2060,2080 & 2060 \\
\hline $\begin{array}{l}\text { Deethylatrazine (2-Chloro-4-isopropylamino-6-amino-s- } \\
\text { triazine) }\end{array}$ & Pesticide degradate & 2003,2060 & 2003 \\
\hline Tebuthiuron & Pesticide & 2003,2060 & 2003 \\
\hline \multicolumn{4}{|c|}{ Results from both methods reported } \\
\hline $1,2,3-\mathrm{TCP}$ & VOC & Weck, 2020 & Weck \\
\hline Alkalinity & Water-quality indicator & field, 1948 & field \\
\hline Arsenic, total & Trace element & 1948, TML & 1948 \\
\hline Iron, total & Trace element & 1948, TML & 1948 \\
\hline Metalaxyl & Fungicide & 2003,2060 & np \\
\hline $\mathrm{pH}$ & Water-quality indicator & field, 1948 & field \\
\hline Specific conductance & Water-quality indicator & field, 1948 & field \\
\hline Tritium & Inorganic tracer & LLNL, SITL & $\mathrm{np}$ \\
\hline
\end{tabular}


Table A3. Constituents detected in blanks collected for the South Coast Range-Coastal (SCRC) Groundwater Ambient Monitoring and Assessment (GAMA) study, California, May to December 2008.

[V-coded data are reported but not used in summary statistics. Abbreviations: E, estimated or having a higher degree of uncertainty; mg/L, milligrams per liter; $\mu \mathrm{g} / \mathrm{L}$, micrograms per liter; $\leq$, less than or equal to; $\mathrm{V}$, analyte detected in sample and an associated blank; thus, data are not included in groundwater quality assessment]

\begin{tabular}{|c|c|c|c|}
\hline Constituent & $\begin{array}{c}\text { Number of } \\
\text { blank } \\
\text { detections/ } \\
\text { analyses }\end{array}$ & $\begin{array}{c}\text { Concentrations } \\
\text { detected } \\
\text { in blanks }\end{array}$ & $\begin{array}{l}\text { Number of } \\
\text { groundwater } \\
\text { samples } \\
\text { V-coded or } \\
\text { coded with } \leq\end{array}$ \\
\hline \multicolumn{4}{|c|}{ Volatile organic compounds (VOC) ( $\mu \mathrm{g} / \mathrm{L})$} \\
\hline 1,1-Dichloroethene (1,1-DCE) & $1 / 14$ & E0.03 & 0 \\
\hline 1,2,4-Trimethylbenzene & $1 / 14$ & E0.08 & 18 \\
\hline Benzene & $1 / 14$ & E0.02 & 0 \\
\hline Methyl ethyl ketone (2-butanone, MEK) & $1 / 14$ & E0.83 & 0 \\
\hline Toluene & $2 / 14$ & 0.18, E0 0.03 & 2 \\
\hline \multicolumn{4}{|c|}{ Trace elements ( $\mu \mathrm{g} / \mathrm{L})$} \\
\hline Chromium & $1 / 7$ & 2.2 & 16 \\
\hline Copper & $1 / 7$ & 2.3 & 17 \\
\hline Lead & $1 / 7$ & 0.31 & 24 \\
\hline Nickel & $1 / 7$ & 0.25 & 3 \\
\hline Zinc & $1 / 6$ & 11.5 & 22 \\
\hline \multicolumn{4}{|c|}{ Nutrients and dissolved organic carbon (DOC) (mg/L) } \\
\hline Ammonia (as nitrogen) & $1 / 5$ & E0.01 & 0 \\
\hline Total nitrogen (nitrate + nitrite + ammonia + organic-nitrogen) & $1 / 5$ & 0.12 & 0 \\
\hline Phosphate, orthophosphate (as phosphorus) & $1 / 5$ & E0.004 & 0 \\
\hline DOC & $1 / 3$ & E0.3 & 13 \\
\hline \multicolumn{4}{|c|}{ Major and minor ions (mg/L) } \\
\hline Chloride & $1 / 7$ & 0.48 & 0 \\
\hline Silica $\left(\right.$ as $\left.\mathrm{SiO}_{2}\right)$ & $2 / 7$ & E0.013, E0.012 & 0 \\
\hline
\end{tabular}




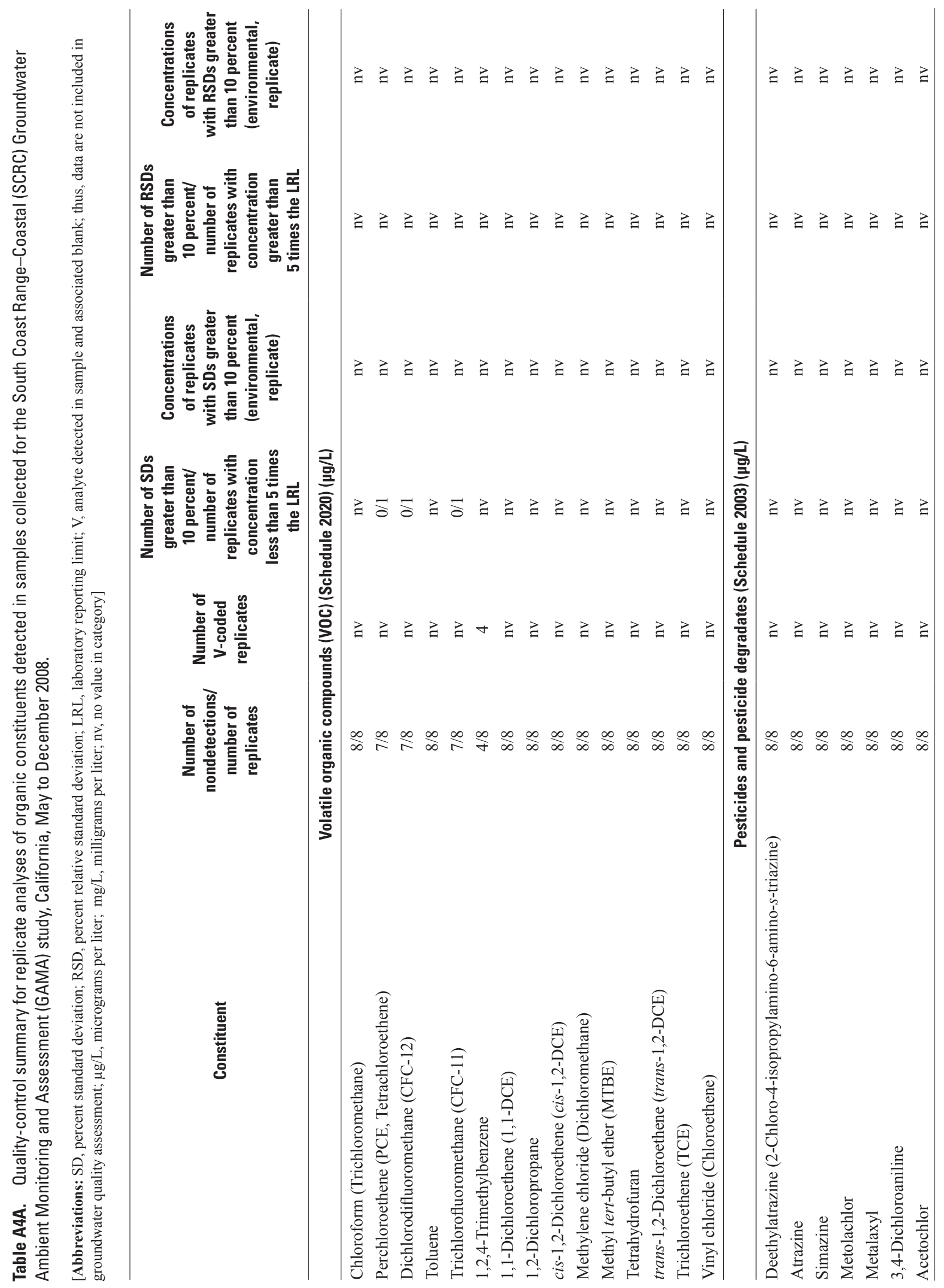




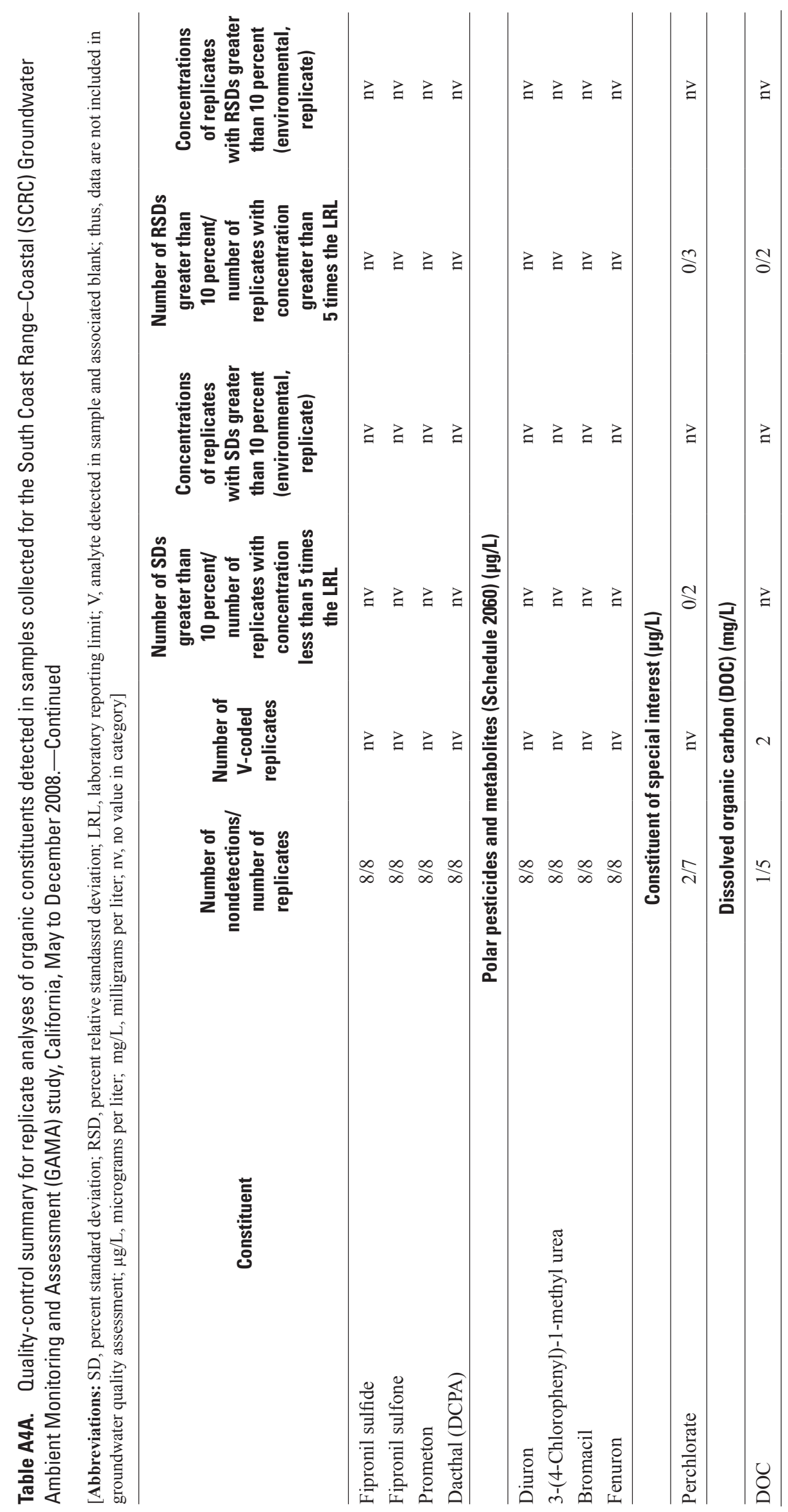




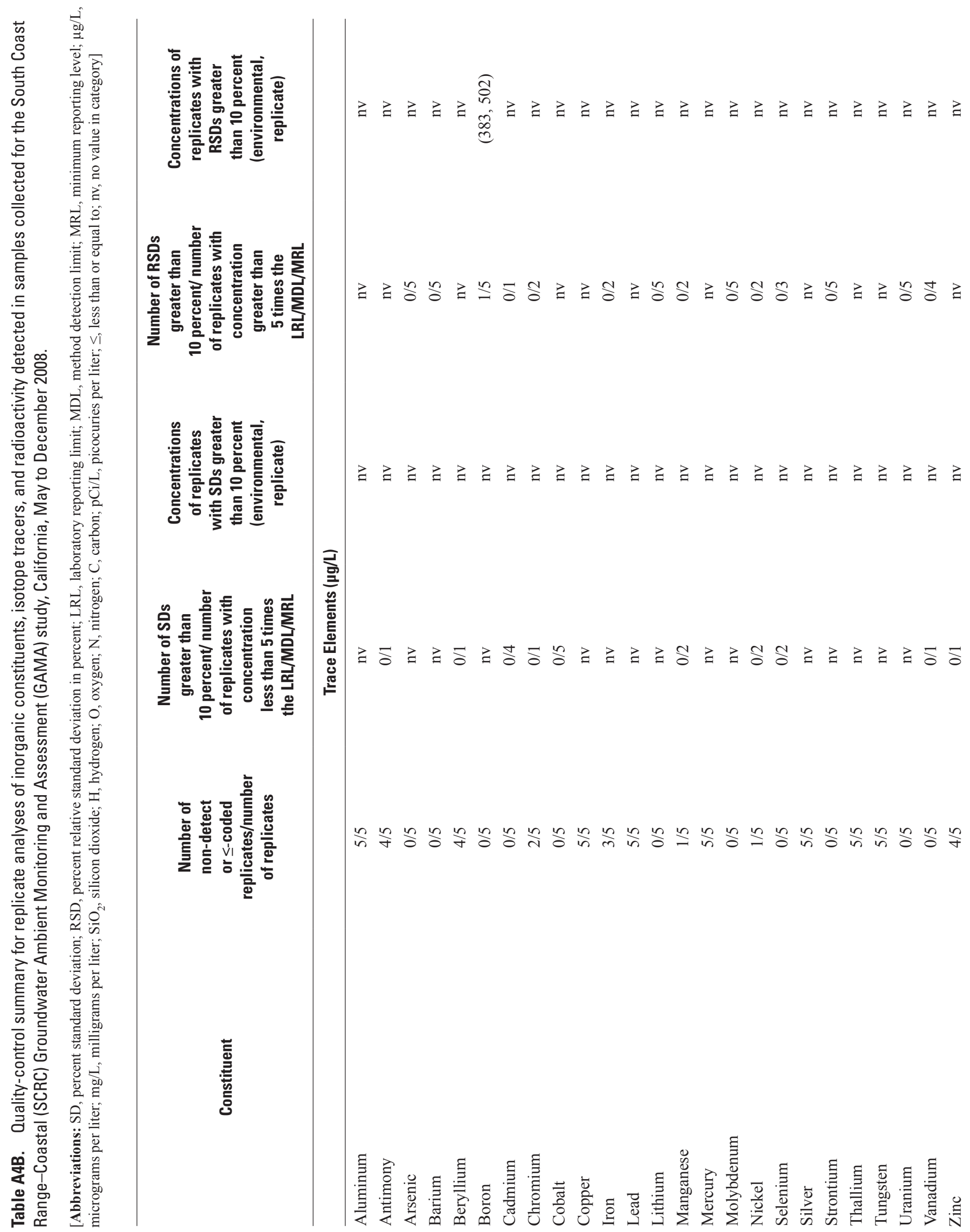




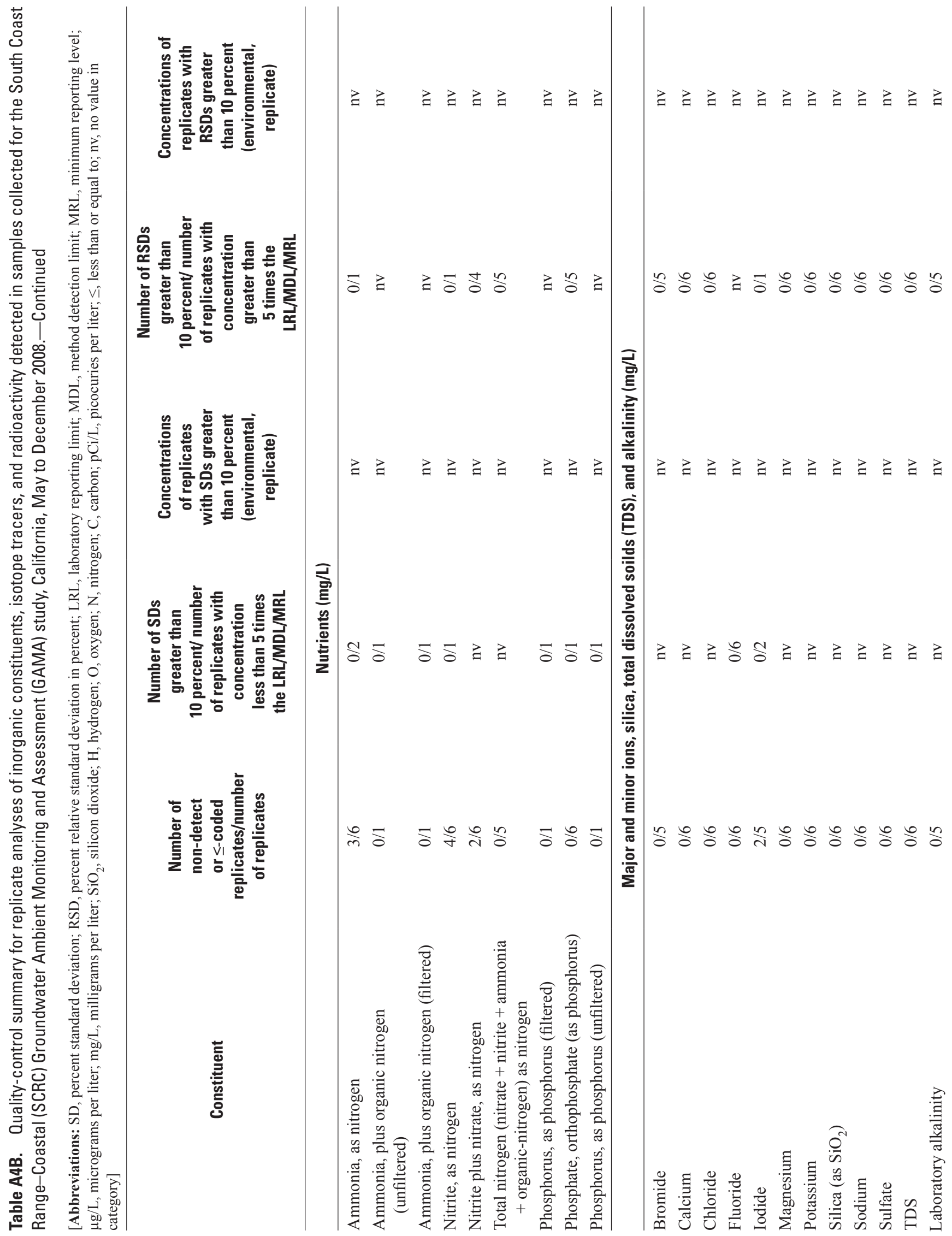




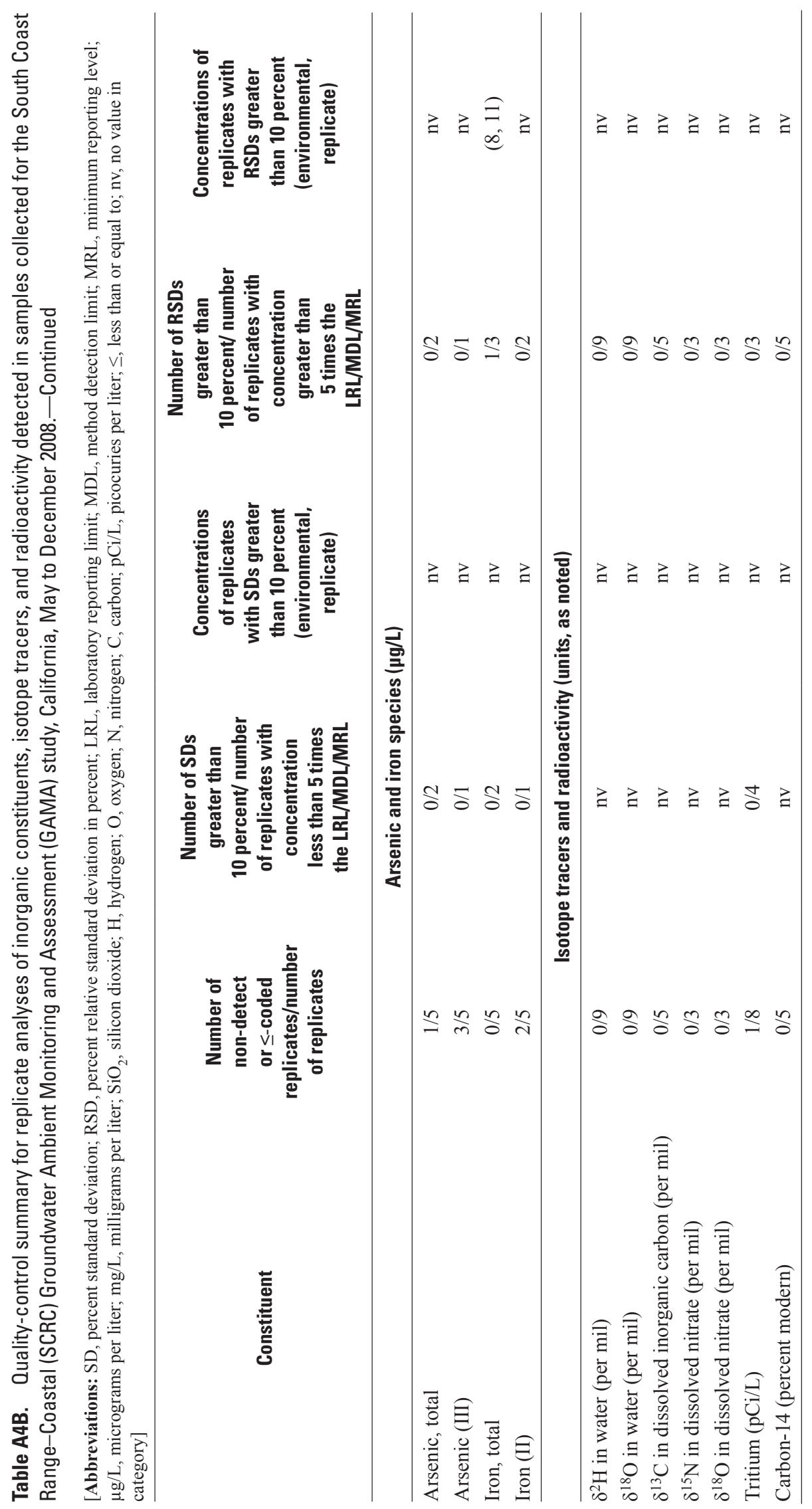


Table A4C. Quality-control summary for replicate analyses of gross alpha and gross beta radioactivity detected in samples collected for the South Coast Range-Coastal (SCRC) Groundwater Ambient Monitoring and Assessment (GAMA) study, California, May to December 2008.

[Abbreviations: CSU, 1-sigma combined standard uncertainty; \pm , plus or minus; pCi/L, picocuries per liter; —, not detected; nv, no value in category]

\begin{tabular}{lcc}
\hline Constituent & $\begin{array}{c}\text { Number of } \\
\text { non-overlapping } \\
\text { values/ number } \\
\text { of replicates }\end{array}$ & $\begin{array}{c}\text { Activites for replicates } \\
\text { with non-overlapping values } \\
\text { (environmental } \pm \text { CSU, replicate } \pm \text { CSU) } \\
\text { (pCi/L) }\end{array}$ \\
\hline Gross alpha radioactivity, 72 hour count & $2 / 4$ & $(4.83 \pm 0.9,2.55 \pm 0.66)(-, 4.2 \pm 1.3)$ \\
Gross alpha radioactivity, 30 day count & $1 / 4$ & $(1.18 \pm 0.81,3.3 \pm 1.2)$ \\
Gross beta radioactivity, 72 hour count & $0 / 4$ & $\mathrm{nv}$ \\
Gross beta radioactivity, 30 day count & $0 / 4$ & $\mathrm{nv}$ \\
\hline
\end{tabular}


Table A5A. Quality-control summary for matrix-spike recoveries of volatile organic compounds (VOC) in samples collected for the South Coast Range-Coastal (SCRC) Groundwater Ambient Monitoring and Assessment (GAMA) study, California, May to December 2008.

[Acceptable recovery range is between 70 and 130 percent]

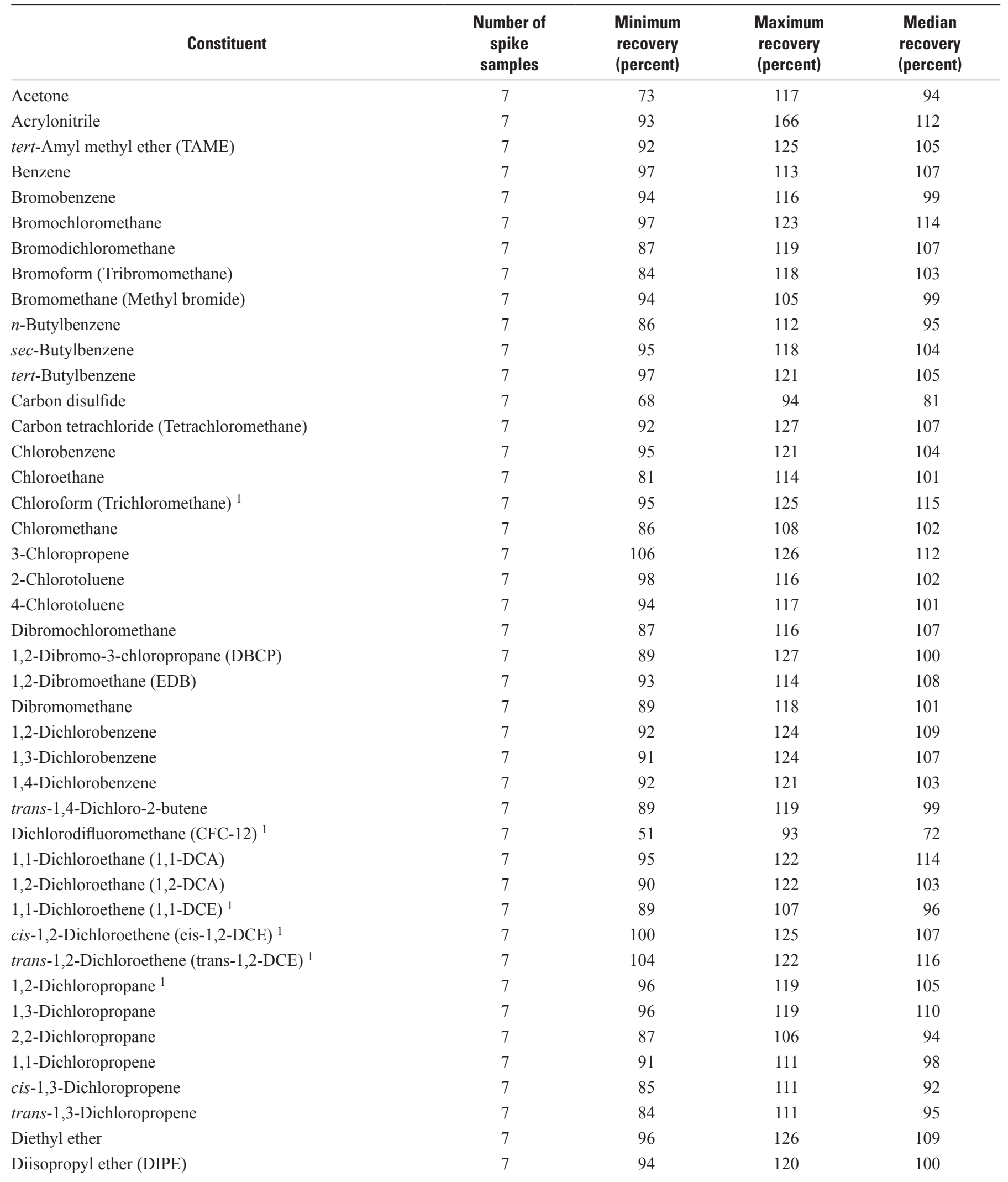


Table A5A. Quality-control summary for matrix-spike recoveries of volatile organic compounds (VOC) in samples collected for the South Coast Range-Coastal (SCRC) Groundwater Ambient Monitoring and Assessment (GAMA) study, California, May to December 2008.-Continued

[Acceptable recovery range is between 70 and 130 percent]

\begin{tabular}{|c|c|c|c|c|}
\hline Constituent & $\begin{array}{l}\text { Number of } \\
\text { spike } \\
\text { samples }\end{array}$ & $\begin{array}{l}\text { Minimum } \\
\text { recovery } \\
\text { (percent) }\end{array}$ & $\begin{array}{l}\text { Maximum } \\
\text { recovery } \\
\text { (percent) }\end{array}$ & $\begin{array}{l}\text { Median } \\
\text { recovery } \\
\text { (percent) }\end{array}$ \\
\hline Ethylbenzene & 7 & 92 & 122 & 101 \\
\hline Ethyl tert-butyl ether (ETBE) & 7 & 89 & 130 & 101 \\
\hline Ethyl methacrylate & 7 & 91 & 118 & 97 \\
\hline$o$-Ethyl toluene (1-Ethyl-2-methyl benzene) & 7 & 87 & 116 & 99 \\
\hline Hexachloroethane & 7 & 87 & 119 & 105 \\
\hline 2-Hexanone ( $n$-Butyl methyl ketone) & 7 & 90 & 112 & 100 \\
\hline Iodomethane (Methyl iodide) & 7 & 92 & 123 & 115 \\
\hline Isopropylbenzene & 7 & 84 & 122 & 98 \\
\hline 4-Isopropyl-1-methyl benzene & 7 & 92 & 113 & 104 \\
\hline Methyl iso-butyl ketone (MIBK) & 7 & 88 & 113 & 97 \\
\hline Methylene chloride (Dichloromethane) ${ }^{1}$ & 7 & 78 & 111 & 109 \\
\hline Methyl ethyl ketone (2-butanone, MEK) & 7 & 85 & 117 & 99 \\
\hline Methyl methacrylate & 7 & 85 & 121 & 94 \\
\hline Naphthalene & 7 & 86 & 116 & 103 \\
\hline Perchloroethene (PCE, Tetrachloroethene) ${ }^{1}$ & 7 & 96 & 140 & 103 \\
\hline$n$-Propylbenzene & 7 & 86 & 116 & 98 \\
\hline Styrene & 7 & 4 & 119 & 104 \\
\hline 1,1,1,2-Tetrachloroethane & 7 & 89 & 126 & 109 \\
\hline 1,1,1-Trichloroethane (1,1,1-TCA) & 7 & 91 & 123 & 106 \\
\hline 1,1,2-Trichloroethane (1,1,2-TCA) & 7 & 88 & 118 & 111 \\
\hline Trichloroethene (TCE) $^{1}$ & 7 & 93 & 112 & 99 \\
\hline Trichlorofluoromethane (CFC-11) ${ }^{1}$ & 7 & 75 & 148 & 99 \\
\hline $1,2,3-\mathrm{TCP}$ & 7 & 85 & 124 & 106 \\
\hline Trichlorotrifluoroethane (CFC-113) & 7 & 72 & 120 & 86 \\
\hline 1,2,3-Trimethylbenzene & 7 & 100 & 127 & 108 \\
\hline 1,2,4-Trimethylbenzene & 7 & 89 & 115 & 104 \\
\hline 1,3,5-Trimethylbenzene & 7 & 88 & 115 & 103 \\
\hline Vinyl bromide (Bromoethene) & 7 & 58 & 129 & 109 \\
\hline Vinyl chloride (Chloroethene) ${ }^{1}$ & 7 & 91 & 126 & 109 \\
\hline$m$ - and $p$-Xylene & 7 & 97 & 120 & 106 \\
\hline$o$-Xylene & 7 & 87 & 126 & 99 \\
\hline
\end{tabular}

\footnotetext{
${ }^{1}$ Constituents detected in groundwater samples.
} 
Table A5B. Quality-control summary for matrix-spike recoveries of pesticides and pesticide degradates in samples collected for the South Coast Range-Coastal (SCRC) Groundwater Ambient Monitoring and Assessment (GAMA) study, California, May to December 2008.

[Acceptable recovery range is between 70 and 130 percent]

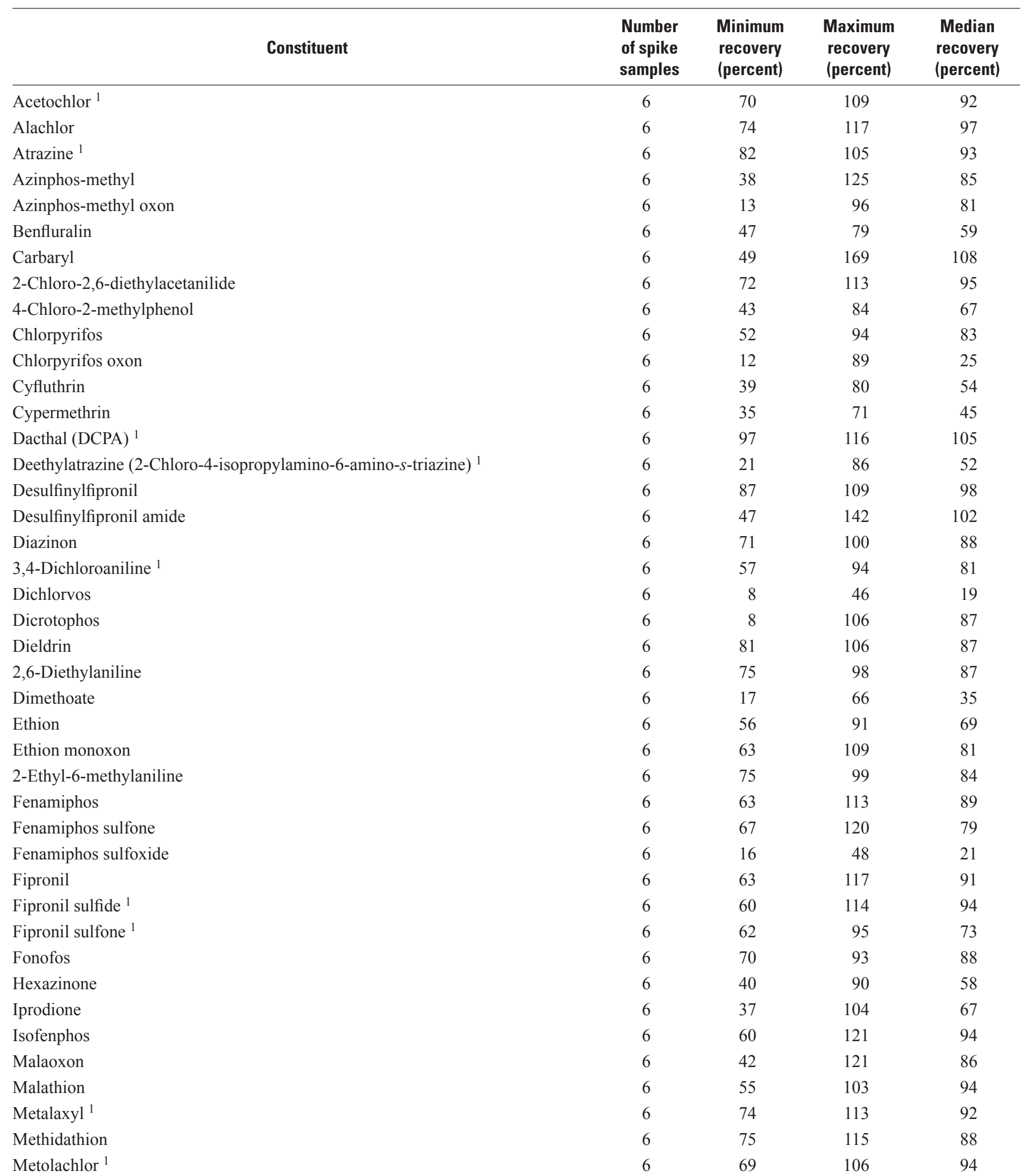


Table A5B. Quality-control summary for matrix-spike recoveries of pesticides and pesticide degradates in samples collected for the South Coast Range-Coastal (SCRC) Groundwater Ambient Monitoring and Assessment (GAMA) study, California, May to December 2008.-Continued

[Acceptable recovery range is between 70 and 130 percent]

\begin{tabular}{|c|c|c|c|c|}
\hline Constituent & $\begin{array}{l}\text { Number } \\
\text { of spike } \\
\text { samples }\end{array}$ & $\begin{array}{l}\text { Minimum } \\
\text { recovery } \\
\text { (percent) }\end{array}$ & $\begin{array}{c}\text { Maximum } \\
\text { recovery } \\
\text { (percent) }\end{array}$ & $\begin{array}{l}\text { Median } \\
\text { recovery } \\
\text { (percent) }\end{array}$ \\
\hline Myclobutanil & 6 & 68 & 100 & 83 \\
\hline 1-Naphthol & 6 & 13 & 61 & 31 \\
\hline Paraoxon-methyl & 6 & 25 & 71 & 63 \\
\hline Pendimethalin & 6 & 66 & 117 & 94 \\
\hline cis-Permethrin & 6 & 31 & 74 & 42 \\
\hline Phorate & 6 & 37 & 75 & 62 \\
\hline Phorate oxon & 6 & 71 & 122 & 87 \\
\hline Phosmet & 6 & 10 & 23 & 20 \\
\hline Pronamide (Propyzamide) & 6 & 61 & 109 & 91 \\
\hline Simazine $^{1}$ & 6 & 66 & 110 & 85 \\
\hline Tebuthiuron & 6 & 57 & 161 & 106 \\
\hline Terbufos & 6 & 52 & 92 & 74 \\
\hline Terbufos oxon sulfone & 6 & 42 & 119 & 95 \\
\hline Terbuthylazine & 6 & 86 & 113 & 98 \\
\hline Tribufos & 6 & 40 & 84 & 57 \\
\hline Trifluralin & 6 & 54 & 89 & 71 \\
\hline
\end{tabular}

\footnotetext{
${ }^{1}$ Constituents detected in groundwater samples.
} 
Table A5C. Quality-control summary for matrix-spike recoveries of polar pesticides and metabolites in samples collected for the South Coast Range-Coastal (SCRC) Groundwater Ambient Monitoring and Assessment (GAMA) study, California, May to December 2008.

[Acceptable recovery range is between 70 and 130 percent]

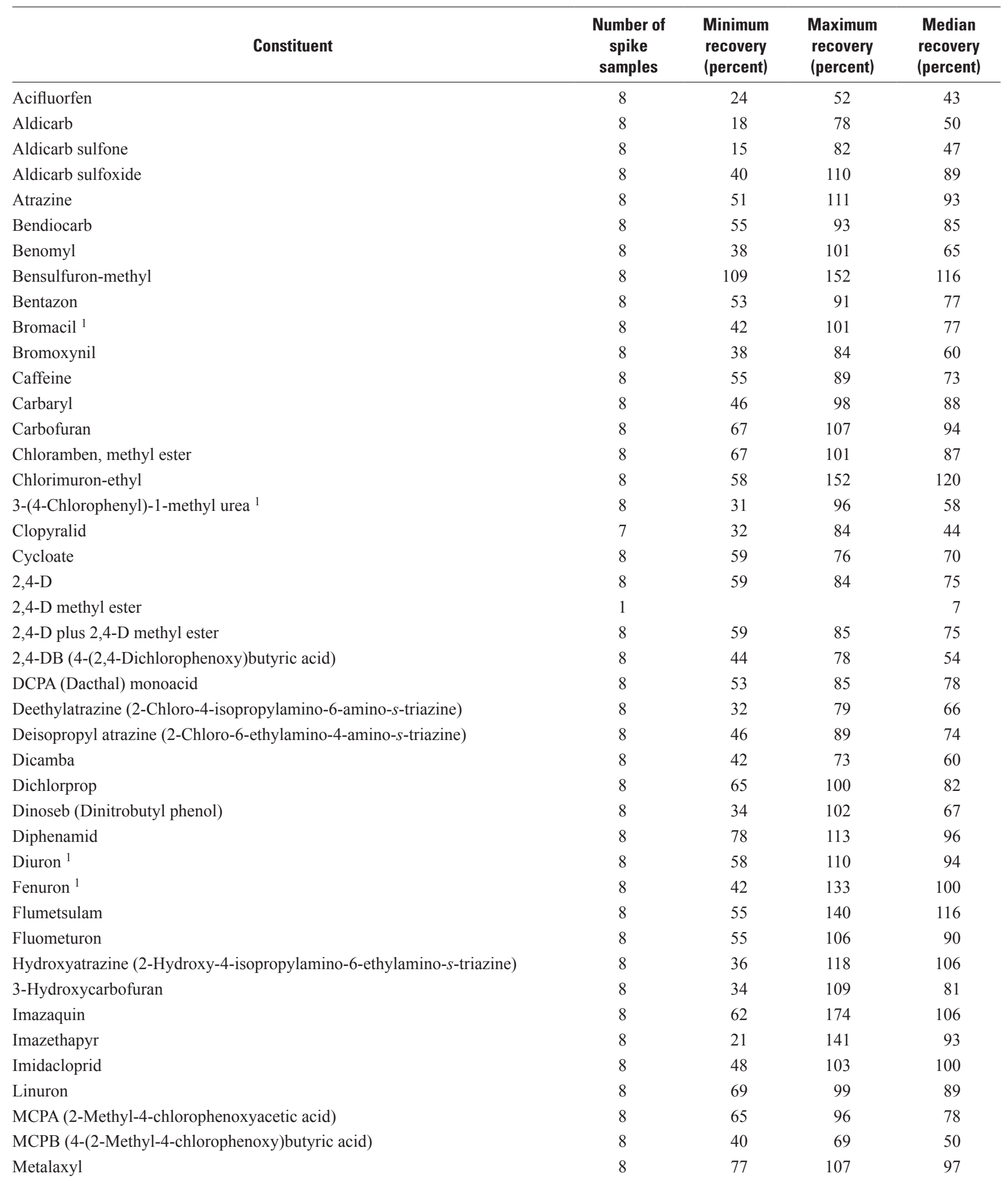


Table A5C. Quality-control summary for matrix-spike recoveries of polar pesticides and metabolites in samples collected for the South Coast Range-Coastal (SCRC) Groundwater Ambient Monitoring and Assessment (GAMA) study, California, May to December 2008.Continued

[Acceptable recovery range is between 70 and 130 percent]

\begin{tabular}{|c|c|c|c|c|c|}
\hline & Constituent & $\begin{array}{l}\text { Number of } \\
\text { spike } \\
\text { samples }\end{array}$ & $\begin{array}{l}\text { Minimum } \\
\text { recovery } \\
\text { (percent) }\end{array}$ & $\begin{array}{c}\text { Maximum } \\
\text { recovery } \\
\text { (percent) }\end{array}$ & $\begin{array}{l}\text { Median } \\
\text { recovery } \\
\text { (percent) }\end{array}$ \\
\hline Methomyl & & 8 & 73 & 120 & 97 \\
\hline Metsulfuron methyl & & 8 & 13 & 149 & 93 \\
\hline Neburon & & 8 & 69 & 93 & 83 \\
\hline Norflurazon & & 8 & 78 & 107 & 97 \\
\hline Oryzalin & & 8 & 60 & 83 & 73 \\
\hline Oxamyl & & 8 & 67 & 100 & 88 \\
\hline Picloram & & 7 & 35 & 89 & 59 \\
\hline Propham & & 8 & 63 & 94 & 83 \\
\hline Sulfometuron-methyl & & 8 & 80 & 151 & 119 \\
\hline Tebuthiuron & & 8 & 54 & 129 & 94 \\
\hline Terbacil & & 8 & 51 & 95 & 76 \\
\hline Triclopyr & & 8 & 62 & 90 & 76 \\
\hline
\end{tabular}

${ }^{1}$ Constituents detected in groundwater samples. 
Table A5D. Quality-control summary for matrix-spike recoveries of constituents of special interest in samples collected for the South Coast Range-Coastal (SCRC) Groundwater Ambient Monitoring and Assessment (GAMA) study, California, May to December 2008.

[Acceptable recovery range is between 70 and 130 percent]

\begin{tabular}{lcccc}
\hline Constituent & $\begin{array}{c}\text { Number of } \\
\text { spike } \\
\text { samples }\end{array}$ & $\begin{array}{c}\text { Minimum } \\
\text { recovery } \\
\text { (percent) }\end{array}$ & $\begin{array}{c}\text { Maximum } \\
\text { recovery } \\
\text { (percent) }\end{array}$ & $\begin{array}{c}\text { Median } \\
\text { recovery } \\
\text { (percent) }\end{array}$ \\
\hline Perchlorate $^{1}$ & 4 & 88 & 106 & 100 \\
$N$-nitrosodimethylamine (NDMA) & 2 & 63 & 86 & 117 \\
$1,2,3$-TCP & 6 & 81 & 101 \\
\hline
\end{tabular}

${ }^{1}$ Constituents detected in groundwater samples.

Table A5E. Quality-control summary for matrix-spike recoveries of gross alpha and gross beta radioactivity in samples collected for the South Coast Range-Coastal (SCRC) Groundwater Ambient Monitoring and Assessment (GAMA) study, California, May to December 2008.

[Acceptable recovery range is between 70 and 130 percent]

\begin{tabular}{lcccc}
\hline \multicolumn{1}{c}{ Constituent } & $\begin{array}{c}\text { Number of } \\
\text { spike } \\
\text { samples }\end{array}$ & $\begin{array}{c}\text { Minimum } \\
\text { recovery } \\
\text { (percent) }\end{array}$ & $\begin{array}{c}\text { Maximum } \\
\text { recovery } \\
\text { (percent) }\end{array}$ & $\begin{array}{c}\text { Median } \\
\text { recovery } \\
\text { (percent) }\end{array}$ \\
\hline Gross alpha radioactivity, 72 -hour count ${ }^{1}$ & 3 & 83 & 96 \\
Gross alpha radioactivity, 30-day count ${ }^{1}$ & 3 & 94 & 112 \\
Gross beta radioactivity, 72 -hour count $^{1}$ & 3 & 80 & 90 \\
Gross beta radioactivity, 30-day count $^{1}$ & 3 & 86 & 93 & 92 \\
\hline
\end{tabular}

\footnotetext{
${ }^{1}$ Constituents detected in groundwater samples.
} 


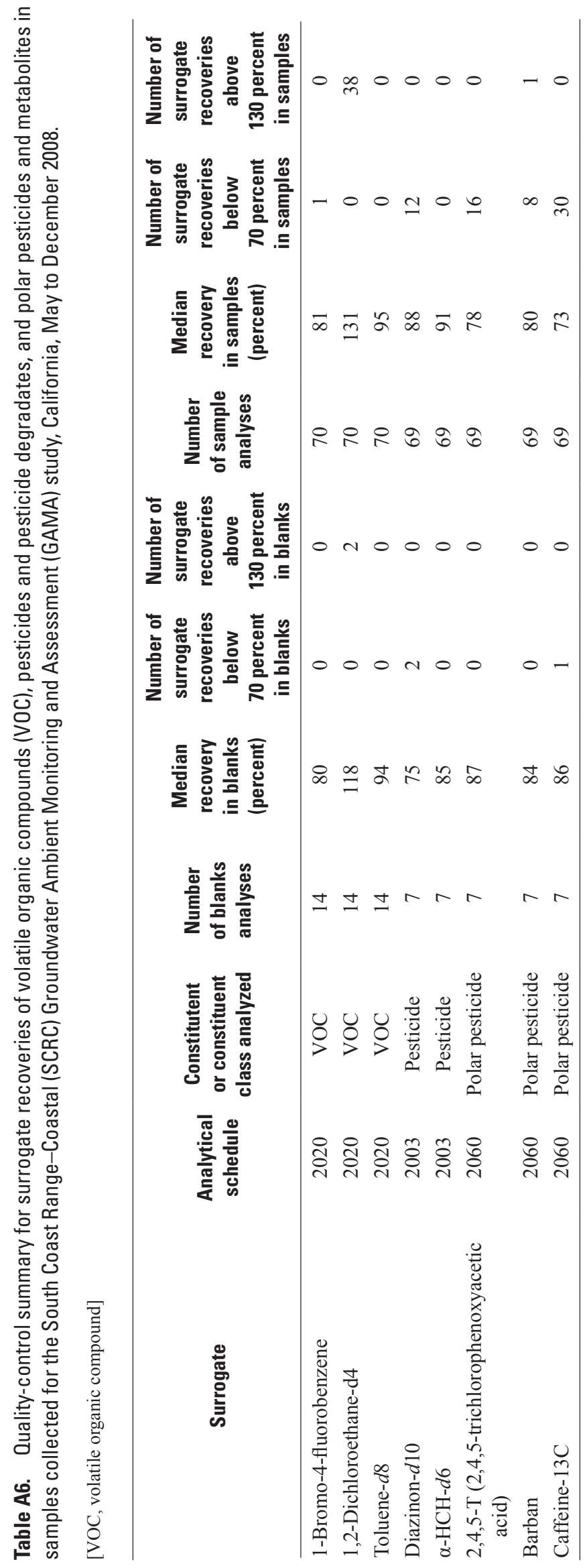


This page intionally left blank. 


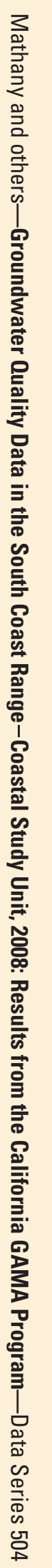

Printed on recycled paper 